\title{
Geografi, \\ kunnskap, \\ vitenskap
}

Den regionale UH-sektorens framvekst og betydning

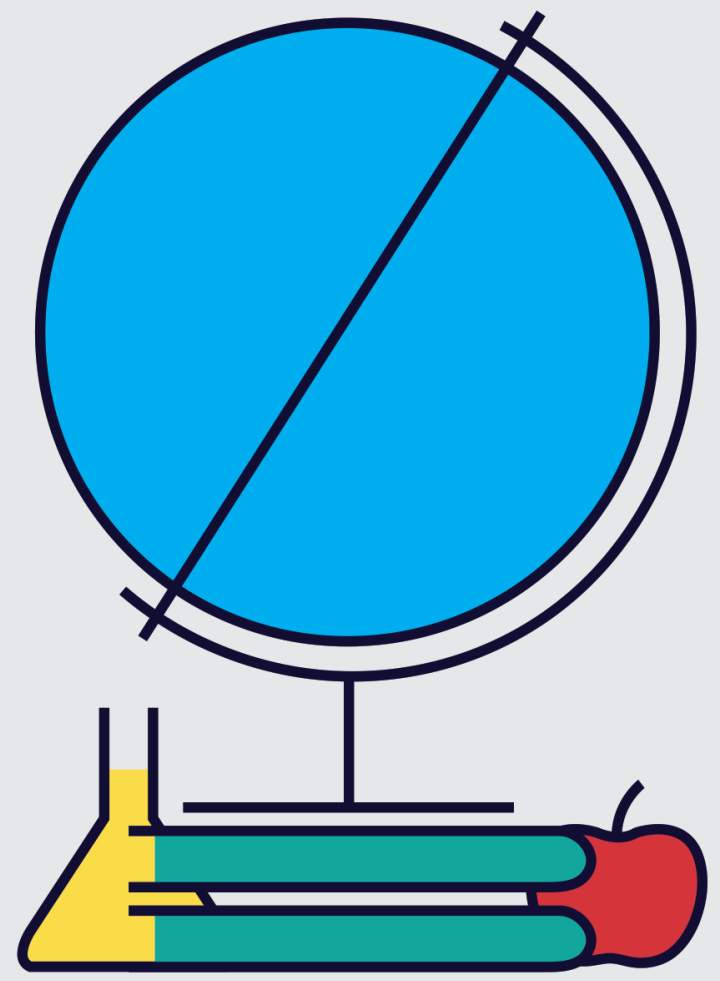

Jon P. Knudsen og Torunn Lauvdal (red.)

NOASP 
Geografi, kunnskap, vitenskap 

Jon P. Knudsen og Torunn Lauvdal (red.)

\section{Geografi, kunnskap, vitenskap}

DEN REGIONALE UH-SEKTORENS FRAMVEKST OG BETYDNING 
() 2019 Jon P. Knudsen, Torunn Lauvdal, Utku Ali Rıza Alpaydın, Peter Arbo, Ivar Bleiklie, Joakim Caspersen, Rune Dahl Fitjar, Nicoline Frølich, Linda Helén Haukland, Hans Christian Garmann Johnsen, James Karlsen, Lars Lyby, Roger Normann, Rómulo Pinheiro, Ingvild Reymert, Jarle Trondal og Per Olaf Aamodt.

Dette verket omfattes av bestemmelsene i Lov om opphavsretten til åndsverk m.v. av 1961. Verket utgis Open Access under betingelsene i Creative Commons-lisensen CC-BY 4.0 (http://creativecommons.org/licenses/by/4.0/). Denne tillater tredjepart å kopiere, distribuere og spre verket i hvilket som helst medium eller format, og å remixe, endre, og bygge videre på materialet til et hvilket som helst formål, inkludert kommersielle, under betingelse av at korrekt kreditering og en lenke til lisensen er oppgitt, og at man indikerer om endringer er blitt gjort. Tredjepart kan gjøre dette på enhver rimelig måte, men uten at det kan forstås slik at lisensgiver bifaller tredjepart eller tredjeparts bruk av verket.

Boken er utgitt med støtte fra Universitetet i Agder.

ISBN trykt bok: 978-82-02-65547-1

ISBN PDF: 978-82-02-63257-1

ISBN EPUB: 978-82-02-65995-0

ISBN HTML: 978-82-02-65996-7

ISBN XML: 978-82-02-65997-4

DOI: https://doi.org/10.23865/noasp.73

Dette er en fagfellevurdert antologi.

Omslagsdesign: Cappelen Damm AS

Cappelen Damm Akademisk/NOASP

noasp@cappelendamm.no 


\section{Innhold}

Innledning

Kapittel 1 Instrument eller institusjon? Skiftende politiske prioriteringer....25 Per Olaf Aamodt, Lars Lyby

Kapittel 2 Regionale universiteter og utdanningspolitiske paradokser ..........53 Ivar Bleiklie

Kapittel 3 Reformer i UH-sektoren. Det muliges kunst 75

Nicoline Frolich, Jarle Trondal, Joakim Caspersen, Ingvild Reymert

Kapittel 4 Universitet og region - en sammensatt relasjon 99

Peter Arbo

Kapittel 5 Forskningens regionale betydning .131 Hans Christian Garmann Johnsen

Kapittel 6 Den tredje rollen: Fra distriktshøgskole til universitet 155 Roger Normann, Rómulo Pinheiro

Kapittel 7 Næringslivets samhandling med universiteter og høgskoler $i$ og utenfor regionen: Funn fra en undersøkelse av norske bedrifter 177 Rune Dahl Fitjar, Utku Ali Riza Alpaydın

Kapittel 8 En diskusjon om universitetets tredje rolle 195 James Karlsen

Kapittel 9 Et paradigmeskifte sett nordfra 219 Linda Helén Haukland

Kapittel 10 Reorganisering av UH-sektoren - nasjonsbygging med regionsmak 241

Jon P. Knudsen 



\section{Innledning}

\section{Bakgrunn}

Et av trekkene som har preget samfunnsutviklingen i etterkrigstidens Norge, er den voldsomme økningen i tilgangen til og betydningen av høyere utdanning - og etter hvert også forskning. I seg selv er dette et trekk vi ikke er alene om. Vi kan på mange vis se en tilsvarende utvikling i andre land. Når kunnskap defineres som vår tids fremste ressurs (Johnsen, 2014), er det som forventet at alt settes inn på å utnytte denne ressursen til beste for samfunnet. Det spesielle for vårt land er heller hvordan denne utviklingen har tatt form i et geografisk perspektiv. Alle land har noen politikkfelt som fremtrer som overordnet andre politikkområder. I Finland har det historisk vært utenriks- og sikkerhetspolitikk. I Sverige har arbeidsmarkedspolitikken spilt en slik rolle. I Norge har utfordringen med å sveise sammen et land med sterke og sprikende regionale og lokale identiteter, behov og tilpasninger, vært styrende for nasjonsbyggingsprosjektet i stort (Rokkan, 1967) og for sektorpolitikkenes utforming (Knudsen, 2018). Trygve Bull (1980) kommenterte en gang at utfordringen med å holde det geografisk mangfoldige Norge samlet, var den altoverskyggende politiske utfordringen for enhver regjering.

Den politikken som til enhver tid er blitt ført for å bygge ut høyere utdanning og forskning, bærer umiskjennelig preg av å være en del av et slikt prosjekt. Utdannings- og forskningspolitikken har gjennomløpt ulike faser og vært underlagt skiftende paradigmer, men den har også vært preget og styrt av aktører som i arbeidet med å realisere sektorpolitiske mål, samtidig - bevisst eller ubevisst - har utført verket som nasjonale strateger (Slagstad, 1998). Resultatet av denne prosessen ble dermed at Norge ved inngangen til 1990-tallet antakelig hadde et av verdens mest desentraliserte UH-systemer målt i forhold til folketallet. Deretter startet en epoke kjennetegnet av en serie reformer for konsentrasjon og samling. 
Dette førte i seg selv ikke til at de regionale ambisjoner minsket, de skiftet bare form. Akademisk drift nedenfra og ønsker om konsentrasjon ovenfra kunne møtes i et kompromiss om institusjonell oppgradering.

Denne oppgraderingen måtte også gis en geografi. Og her ser vi hvordan den geografiske utfordring gripes ulikt an. Mens Gudmund Hernes ønsket å tegne kartet ovenfra, delte Torbjørn Røe Isaksen ut tegnesaker til de regionale aktører med beskjed om å gjøre opp sitt bestikk selv ut fra regionale forutsetninger og ressurser. Begge tilnærmingsmåter var kontroversielle. Der noen applauderte, egget andre til motstand. Geografi er stadig noe man ikke tar lett på i Norge. I skrivende stund er det særlig rundt Nord universitets organisering og fremtid at bølgene går høye. I morgen kan det være andre institusjoner og regioner som står i fokus for oppmerksomhet.

I denne antologien tar vi mål av oss til å gi et riss av den historiske utviklingen som har preget den sektoren vi beskriver. Hvordan forstår og forklarer vi den utviklingen vi har hatt? Hvilke interesser, drivkrefter og aktører kan vi identifisere? Hva har konsekvensene for sektoren selv og for samfunnet vært av måten vi i Norge har løst utfordringene på? I noen grad forsøker vi også å se litt fremover med utgangspunkt i hvor vi nå befinner oss.

Oppspillet til denne antologien var et seminar vi som redaktører tok initiativ til i oktober 2018, da vi inviterte et knippe kolleger til Universitetet i Agder, Kristiansand, for å drøfte disse viktige spørsmålene. Bidragene vi fikk, oppfattet vi som så verdifulle at vi raskt bestemte oss for å supplere gruppen av bidragsytere og å lage en bok som også kunne fungere som grunnlag for en ny konferanse i Kristiansand, der vi sammen med noen av de 'nye' universitetene - Universitetet i Stavanger (UiS), Nord universitet og Universitetet i Sørøst-Norge (USN) - fulgte opp den diskusjonen vi begynte ved UiA i fjor. Denne boka lanseres i samband med denne konferansen.

Bidragene til antologien kommer fra personer og miljøer som på ulikt vis har fulgt utviklingen av den regionale dimensjonen innenfor norsk høyere utdanning og forskning i kortere eller lengre tid, noen som forskere, noen som praktikere, og noen i begge roller. De teoretiske og empiriske inngangene til temaet er ulike. Felles er interessen for å forstå og å analysere historien bak og utfordringene for den sektoren forfatterne selv i varierende grad er en del av. I så måte kan vi, som så ofte når det 
regionale aspektet ved samfunnsutviklingen kommer opp til debatt, også registrere at få av forfatterne kommer unna en personlig involvering med tematikken. Vi har styrt unna termen 'geografi og kjærlighet', men registrerer at forfatterrollen for flere av de medvirkende også gjenspeiler deres egen refleksjon over forholdet mellom å være deltaker i og tilskuer til prosesser og hendelser det stoffet som presenteres, relaterer til. I sitt teoretiske og empiriske mangfold mener vi at kapitlene til sammen gir et dekkende bilde av det de skal formidle: den spennende utviklingen bak den UH-sektoren vi i dag har, og de forutsetninger dette gir for å utvikle sektoren videre.

\section{Om kapitlene i boka}

\section{Kapittel 1}

Kapittel 1 gir en historisk bakgrunn for de forhold som beskrives i de etterfølgende kapitler. Kapitlet reiser spørsmålet om hvordan den regionale betydningen av høyere utdanning har blitt vektlagt i utdanningspolitikken, med et hovedfokus på perioden fra og med 1960-tallet fram til i dag. Med henvisning til kapittel 6 trekkes det fram en sondring mellom universiteter og høgskoler som institusjon og instrument. Vektleggingen av universiteter og høgskolers eksterne betydning for regional (økonomisk) utvikling medierer et instrumentelt perspektiv på institusjonene, mens forestillingen om institusjonene som selvorganiserende enheter med sitt indre liv og sine logikker utgjør det institusjonelle perspektivet. Denne dikotomien brukes i analysene av utdanningspolitikken for å vise vekslinger i prioriteringer og mål.

Kapitlet beskriver videre framveksten av en distriktsorientert politikk for høyere utdanning på 1960- og 1970-tallet. Utover på 1960-tallet vokste bekymringen for avfolking i distriktene, særlig gjennom flytting til sentrale strøk på Østlandet. Middelet var etablering av studieplasser, spesielt i høgskoler utover landet, for å skape større regional tilgang på utdannet arbeidskraft og samtidig gi like muligheter til utdanning for ungdom uansett bosted. Eksempler på dette er etablering av Universitetet i Tromsø og etablering av distriktshøgskolene. 
Forfatterne viser at da opprettelse av distriktshøgskolene ble foreslått, var forslaget at man skulle samle høgskolene geografisk innenfor hver region. Dette ble ikke ble fulgt opp. Resultatet var at man fikk en svært spredt sektor med mange små institusjoner. De viser så hvordan ledende politikere utover på 1980-tallet begynte å stille spørsmål om den store spredningen av studietilbud var hensiktsmessig. Samtidig kom krav fra flere hold om konsentrasjon av tilbudsstrukturen. Denne spenningen mellom spredning og konsentrasjon har vært sentral helt fram til i dag. Den sto sentralt i 9o-tallets reformer, der vekten på konsentrasjon, konsolidering og spesialisering ble fremtredende, og der den statlige høgskolesektoren ved sammenslåing i 1994 ble redusert fra 100 til 26 institusjoner. Ønsket om konsentrasjon har også stått sentralt i utredninger og politikk på 2000-tallet, noe som har resultert i at mens man i 2003 i offentlig sektor hadde 4 universiteter, 7 vitenskapelige høgskoler, og 25 statlige høgskoler, hadde vi i 201810 universiteter, 5 vitenskapelige høgskoler og 5 statlige høgskoler.

Forfatterne viser også hvordan vektleggingen på et (regional-)økonomisk rasjonale fra 9o-tallet kom tydeligere til syne. Mjøs-utvalget pekte for eksempel på at institusjonene i høyere utdanning kan fungere som sentre til å bistå regionene, tiltrekke seg og holde på kompetansekrevende virksomheter, styrke det regionale tilbudet av høyt kvalifisert arbeidskraft og fungere som sosiale og kulturelle samlingssteder.

Den tidlige utbyggingen av desentrale institusjoner var spesielt orientert mot utdanning. Fra 9o-tallet ser vi en større vektlegging på forskning, og etter hvert på kvalitet i forskning og forskningsbasert utdanning. Kvalitet i forskning settes i sammenheng med internasjonalisering, og det kommer en ny spenning til syne, spenningen mellom vekt på det regionale og relevans på den ene siden, og vekt på akademisk kvalitet og det internasjonale på den andre.

\section{Kapittel 2}

Kapittel 2 gir fra et annet perspektiv en sentral bakgrunn for forholdet mellom universitet, høgskole og region. Her rettes søkelyset primært mot endringer i organisering og styringsformer i sektoren, internasjonalt og 
nasjonalt. Spørsmålet som reises, er hvordan disse endringene griper inn i mulighetene for regional samhandling.

Teksten gir en beskrivelse av det som gjerne betegnes som en revolusjon i styring og organisering av høyere utdanning, forstått i lys av to perspektiver. Det ene er et sektorperspektiv med fokus på endringer som resultat av samspill mellom nasjonal utdanningspolitikk (jf. kap. 1) og interne drivkrefter, det andre trekker opp et perspektiv som ser endringene i lys av bredere samfunnsendringer.

De fem styringsrevolusjonene som beskrives, er: 1. Systemintegrasjon, preget av mer felles lovgivning, finansieringssystem og evaluerings- og akkrediteringssystemer i sektoren. 2. Beslutningsprosesser som innebærer mer intern hierarkisk ovenfra-styring ut fra institusjonens strategi. 3. Finansiering, fra direkte bevilgninger basert på innsatsfaktorer som antall fast ansatte og antall studenter, til i økende grad å være basert på resultatfaktorer. 4. Kvalitetssikring og evaluering med økende innslag av organisasjonsmessig evaluering og kvalitetssikring gjennom blant annet etablering av nasjonale og overnasjonale evaluerings- og akkrediteringsorganer. 5 . Arbeidsorganisering. Mens arbeidet tidligere ble utført av enkeltindivider, blir forskning og undervisning nå i økende grad utført av grupper.

Som en konsekvens av disse revolusjonene har måten det styres på, og de ansattes innflytelse internt, blitt endret. Det har skjedd en bevegelse bort fra desentraliserte organiserte anarkier der innflytelse var forankret i ulike disiplinære fellesskap, til penetrerte hierarkier med sterkere ledelse og innvevd i en rekke avhengighetsforhold til viktige interessenter i omgivelsene. Den faglige innflytelsen er i økende grad basert på posisjoner knyttet til forskningsfinansiering, kvalitetsvurdering, redaksjonsutvalg, offentlige utvalg, osv. Det pekes samtidig på at disse endringene har slått inn i ulik grad i de enkelte universitetene. Spørsmålet som stilles, er hvilken betydning dette får for universiteters og høgskolers vilje og mulighet til samhandling med omgivelsene i sin region. Dette belyses også i senere kapitler.

\section{Kapittel 3}

Kapitlet tar for seg arbeidet mot en konkret reform, den såkalte strukturreformen 2015-16, den til nå siste strukturreformen, der det ble vedtatt og 
iverksatt en rekke fusjoner mellom høgskoler og universiteter. Som det også drøftes i kapittel 1, var vi nå kommet i en fase der det politisk ble lagt mer vekt på kvalitet forstått som eksellens i forskning og undervisning. Forfatterne viser hvordan nasjonale politikere presenterte mål, problembeskrivelse og løsning, men samtidig overlot til institusjonene å foreta sine valg og begrunne dem ut fra problembeskrivelsen. Målet var kvalitet formulert som tydelige kvalitetskrav. Problemet ble beskrevet som at sektoren hadde for mange små og sårbare fagmiljøer til å kunne leve opp til disse kravene, og regjeringen antydet at en av konklusjonene i prosessen ville være at man reduserte antallet institusjoner. Samtidig viser analysene at kvalitetsbegrepene som ble fremmet, handlet både om eksellens og relevans, definert som internasjonalt anerkjent forskning og regional relevans presisert som regional utvikling og god tilgang på utdanning $\mathrm{i}$ hele landet. Dermed var konkurrerende målsettinger i spill.

Kapitlet viser at UH-institusjonene i sine tilsvar møtte problembeskrivelsen med mange små og sårbare fagmiljøer gjennom en sammensatt argumentasjon som begrunnet hvert enkelt læresteds forslag om nettopp sin nye plass i UH-strukturen i Norge. Norske UH-institusjoner, som tilsvarende institusjoner andre steder, kjennetegnes av ulike logikker, ulike faglige logikker så vel som faglig-administrative logikker. Dynamikken mellom slike ulike logikker og ulike mål ligger ofte nedlagt i institusjonenes historie, som dermed danner grunnlag for hvordan institusjonene møter nye utfordringer. Forfatterne peker også på at målkonflikter ikke kan organiseres bort, men at et effektivt organisasjonsdesign kan handle om å finne balanse mellom konkurrerende mål.

Kapitlet bygger på analyser av de svar institusjonene ga på ministerens utfordring om å beskrive sine strategiske styrker og plassere seg i et framtidig landskap bestående av færre universiteter og høgskoler. Analysene viser hvordan argumenter knyttet til den enkelte høgskoles regionale rolle hyppig ble brukt for å fremme institusjonens strategiske rolle, og dermed også ligger til grunn for deres vurdering av fusjonsalternativer. Argumentet knyttes til at deres viktigste oppgave er deres nøkkelrolle for å skape kompetanse, være støttespiller for lokalt næringsliv og skape vekst i regionen. Videre handler det om at institusjonene spiller en viktig rolle for å løfte utdanningsnivået i regionen (jf. kap. 1). Men disse argumentene 
ble brukt både for og mot fusjoner. Når man argumenterte for, var det ofte ut fra at man så et behov for å samle fagmiljøer og dermed styrke kompetansen i regionen. Kapitlet beskriver ellers at et generelt samfunnsperspektiv ble brukt som argument. Noen vektla urbanitet og nærhet til større byer, andre hadde rene faglige argumenter. Analysene viser altså et sammensatt sett av begrunnelser for endringene. Forskerne konkluderer derfor med antakelsen om at reformen mobiliserte allerede eksisterende oppfatninger i institusjonene. De enkelte institusjonene møtte forventningene fra de sentrale myndigheter med de argumentene som passet best med deres egen identitet, historie og strategi.

\section{Kapittel 4}

Kapittel 4 går konkret inn i relasjonen mellom region og universitet, og summerer opp bredden av erfaring fra forskning omkring universitetets positive og negative betydning for regionen, og - vice versa - hvilke fordeler og ulemper et universitet kan ha som følge av en tett regional tilknytning. Når det gjelder universitetets betydning for regionen, beskriver kapitlet en lang rekke ringvirkninger de fleste vil oppfatte som positive. Noen eksempler er:

- Multiplikatoreffekt. Inntekts- og etterspørselsvirkninger. Gjennom statlige bevilgninger, bevilgninger fra EU og nasjonale forskningsbevilgninger, er institusjonen med på å tilføre regionen inntekter som kan være betydelige. Midlene som brukes regionalt, bidrar f.eks. til å opprettholde aktivitet innenfor varehandel, transport, bygg og anlegg. Videre bidrar universitetet til skatteinntekter, og studentene legger igjen egne midler og studielån i regionen. Slik kan det økonomiske bidraget til regionen være betydelig.

- Mobiliseringseffekt. Geografisk nærhet gjør at flere i regionen søker høyere utdanning. Når ungdom har utdanningsmuligheter i egen region, vil flere satse på høyere utdanning. Institusjonene virker med det utdanningsmobiliserende.

- Magneteffekt og knoppskytingseffekt. Universitetet tiltrekker seg annen virksomhet som ønsker å være nær institusjonen, som f.eks. 
forskningsmiljøer. Samtidig ser man at nye foretak springer ut av universitetet.

- Politisk effekt. Universitetet bygger og formidler kompetanse som har betydning for regionens selvforståelse og veivalg. Gjennom formidling av forskning, utredningsarbeid og deltakelse i det offentlige ordskiftet er institusjonen med på å tematisere ulike spørsmål som angår regionen.

Forfatteren trekker imidlertid også fram flere effekter som kan oppfattes som negative. Her er eksempler:

- Flyttetilbøyelighet. Folk med høyere utdanning er mer mobile enn folk uten slik utdanning.

- Sentralisering. Universitetet kan ha en sentraliserende effekt i regionen; det kan skape et pressområde.

- Maktforskyvning. Universitetet kan utfordre etablerte maktforhold i regionen.

I spørsmålet om regionens betydning for universitetet trekkes også fram en del forhold som kan gi viktig drahjelp for institusjonen:

- Regionen kan være en viktig politisk og økonomisk støttespiller. Det kan handle om regionale (universitets)fond, og /eller at politikere fra regionen bidrar til å påvirke nasjonale myndigheter.

- Gjennom tett samarbeid med praksisfelt, praksisordninger, trainee-ordninger o.l. kan regionen få stor betydning for utdanningenes kvalitet og yrkesrelevans.

- Kunnskapsutvikling i samspill mellom universitetet og bedrifter, offentlig virksomhet, frivillige organisasjoner og media kan ha stor betydning for universitetets faglige virksomhet.

Samtidig kan regionen også fungere som en hemsko for universitetet når den for eksempel er lite attraktiv og preget av minkende ungdomskull, når forskningen har lite å hente fra regionen, eller hvis universitetet blir drevet til kortsiktige småoppdrag. 
Avslutningsvis beskriver kapitlet noen nye forutsetninger og perspektiver som kan påvirke forholdet mellom universitet og region framover. Dette kan handle om fenomener som at veksten og den store spredningen av høyere utdanning bidrar til at utdanningene blir alminneliggjort, og dermed ikke så synlige. Det kan handle om hvilken betydning kvinnenes inntog i høyere utdanning får for utdanningene og regionene. Videre kan det handle om digitalisering gjennom utnytting av informasjonsteknologi i utdanning og forskning, men også om utvikling av nettbasert utdanning, med internasjonale tilbud som MOOCs. Spørsmålet stilles om hvordan slikt vil forandre forholdet mellom høyere utdanningsinstitusjoner og regioner. Den siste utfordringen som trekkes fram, er spørsmålet om oppløsning av regioner, nye regiondannelser og ulike regioninndelinger på tvers av sektorer. Hva betyr slike prosesser for samspillet? Dette siste spørsmålet blir òg behandlet nærmere i kapittel 9 og 10.

\section{Kapittel 5}

I dette kapitlet presenterer og drøfter forfatteren ulike perspektiver på hvilken rolle forskning kan spille i en region. Han utvikler en modell for hvordan forskningsbasert kunnskap kan påvirke et regionalt kunnskapssystem og systematiserer og analyserer så, i lys av denne modellen, et antall empiriske forskningsprosjekter gjort i en bestemt region (Agder) i løpet av en tiårsperiode.

Hovedtesen er at hva som til syvende og sist skaper sosiale endringer, sannsynligvis involverer samtidig endring av institusjoner, regler, holdninger og normer i samfunnet.

Innledningsvis presenteres tre modeller for forholdet mellom forskning og kunnskapsutvikling. Den lineære modellen ser for seg at kunnskap starter som forskning, gjerne i form av grunnforskning som kommer med ny kunnskap. Innsikten fra forskningen føres så over og anvendes på et konkret felt. Den interaktive modellen lanseres som en alternativ tilnærming, der det legges vekt på et samspill mellom forskere og aktører i et praksisfelt.

Forfatteren argumenterer for at forskningens mer systemiske og kritiske rolle ikke er særlig godt ivaretatt i disse modellene, og argumenterer for en tredje, kunnskapssosiologisk, tilnærming. 
Ut fra dette presenterer kapitlet en modell for et regionalt kunnskapssystem, der de fire dimensjonene verdier og holdninger, interaksjonsmønstre og relasjoner, makt og posisjoner og institusjoner, lover og regler settes opp mot dimensjonene individuell, eksplisitt kunnskap, kollektiv, eksplisitt kunnskap, individuell, implisitt kunnskap og kollektiv, implisitt kunnskap.

Empirien som analyseres, består av 55 prosjekter rettet mot Agderregionen, der man har bedt forskerne beskrive hva de har gjort, og også bedt dem redegjøre for eventuelle strategier for å få til endringer i samfunnet.

Prosjektene blir først analysert i forhold til forskningsstrategi og forskningsfelt, deretter om prosjektene kunne karakteriseres som hjelpende, bekreftende eller kritiske, og til sist for forskningens intensjoner om påvirkning på det regionale kunnskapssystemet.

Det tas forbehold om at de analyserte prosjektene ikke er representative for forskningsprosjekter rettet mot Agder (og dermed ikke mot regioner generelt), samt at man i det foreliggende materialet ikke har data på i hvilken grad forskningen faktisk har lyktes med å påvirke kunnskapsutvikling. Likevel gir analysen av prosjektene et bilde av at forskningens regionale rolle og betydning er langt mer kompleks enn de to refererte modellene, den lineære modellen og interaksjonsmodellen, ser ut til å anta. Det refererte materialet dokumenterer at det finnes et mangfold av tilnærminger tilgjengelig for å påvirke den regionale kunnskapen. Materialet viser også at forskerne har en stor grad av bevissthet om strategier for å påvirke sosial kunnskap. Kapitlet konkluderer med at et kunnskapssosiologisk perspektiv på forskningen er en fruktbar tilnærming til å forstå forskningens regionale betydning.

\section{Kapittel 6}

I dette kapitlet drøftes det forfatterne beskriver som den tredje rollen til UH-institusjoner, samspillet med omgivelsene, som i dette tilfellet er regionen. Samtidig fokuserer de på utviklingen fra høgskole til universitet, og reiser problemstillingen om hva som kjennetegner utviklingen av den tredje rollen når en regional høgskole blir universitet.

De peker på det dilemmaet som er berørt i flere kapitler, at institusjonene, og i dette tilfellet i særlig grad nye universiteter, på den ene siden 
møter økende konkurranse, sterkere krav om forskningskvalitet, internasjonalisering, konkurranse om forskningsmidler og talenter, og på den andre siden regionale behov og forventninger.

Ut fra en modell for styring (governance) og autonomi utvikler de en typologi der den tredje rollen får noe ulikt innhold avhengig av de arenaene som aktiveres. Disse arenaene betegner de som strategiske, teknokratiske, deliberative eller samfunnsarenaer.

De diskuterer videre fire faser i utviklingen av den tredje rollen. Den første beskrives som tiden før høgskolereformen i 1994. Her fungerte de statlige høgskolene hovedsakelig som undervisningsinstitusjoner, og fremsto som samfunnsutviklere gjennom å desentralisere utdanning og bidra til at distriktene fikk tilgang på høyt utdannet arbeidskraft.

Den andre fasen, etter 1994, betegnes som en fase for regional mobilisering. Denne fasen faller sammen med en internasjonal regionaliseringsbølge som også setter avtrykk i norsk politikk. Regionale partnerskap etableres, og felles for flere av dem er at målet om å utvikle høgskolen til universitet blir en samlende strategi. Åpningen i loven for å akkreditere høgskoler til universitet, førte til at NOKUT, det nasjonale akkrediteringsorganet for sektoren, utviklet konkrete kriterier for akkrediteringen. Disse kriteriene dannet grunnlag for et veikart for de mest ambisiøse regionale partnerskapene. I dette arbeidet handlet det også om å frigjøre regionale midler. Agder og Rogaland er her eksempler på regioner som etablerte fond som bidro sterkt til universitetsetableringen.

Den tredje fasen beskrives som en fase for eksperimentering med den tredje rollen. Dette er fasen etter overgang til universitet, der det søkes etter hvordan man best skulle utforme den regionale rollen. Det ble tatt mange nye initiativer, både fra ledelse og fagmiljøer. Forfatterne argumenterer i denne fasen for at universitetene fra å ha forholdt seg til enkeltbedrifter, inngår i strategisk samarbeid med klyngeorganisasjoner i regionen.

Fase fire betegnes som en fase der den tredje rollen ble forbundet med eksellens i forskning. De nye universitetene tok fatt på et arbeid med å profesjonalisere organisasjonen og øke kvalitet i alle ledd i virksomheten. Dermed ble særlig forskningen og forskningskvaliteten i sterkere grad vektlagt. Nasjonalt var der et fokus på etableringen av sentre for fremragende forskning. Det handlet om eksellente miljøer etablert på tvers av 
universiteter. Dette aktualiserte særlig ordningen med FME, forskningssenter for miljøvennlig energi, og SFI, senter for forskningsdrevet innovasjon, som innebar krav om medvirkning fra bedrifter eller klynger. Dette åpnet for samarbeid mellom de nye universitetene, regionale forskningsmiljøer og næringslivet i regionen. Dette samarbeidet lyktes særlig for Universitetet i Agder og Universitetet i Stavanger.

Slik oppsto det i den fjerde fasen på noen områder modeller for å kombinere kravet om eksellens i forskningen med krav om samhandling med regionen.

\section{Kapittel 7}

I kapittel 7 refereres funn fra en undersøkelse blant norske bedrifter, der fokuset er rettet mot bedriftenes samhandling med universiteter og høgskoler i og utenfor regionen de er lokalisert i. Innledningsvis pekes det på at i Norge rapporterer universitetene årlig antall patenter, lisenser og nye foretak, og de fleste av dem får støtte til denne virksomheten gjennom sine TTO-er (technology transfer office). Men disse rapporteringsindikatorene viser kun en liten del av universitetenes bidrag til regional verdiskaping. Deres øvrige bidrag til eksisterende næringsliv og samfunnet blir i liten grad fanget opp. Studier som den som her blir referert, trengs derfor for å skape et bilde av nettopp denne mer regulære samhandlingen. Undersøkelsens utgangspunkt var bedriftsperspektivet, og den tok for seg samhandling i bred forstand. Ved siden av å se på forskningssamarbeid og kommersialisering, så den også på samarbeid knyttet til utdanning, kompetanseutvikling og samfunnsansvar.

I kapitlet presenteres resultater der man spesielt har sett på omfanget av samarbeid med universiteter og høgskoler, bedriftenes motiver for å samarbeide, innholdet i samarbeidet og hvilke universiteter bedriftene samarbeider med.

Noen hovedresultater av undersøkelsen var:

- Av de 1200 intervjuede bedriftene var det 19,3\% som oppga at de hadde hatt kontakt med universiteter eller høgskoler de siste tre årene. 
- Bedriftene oppgir at den viktigste årsaken til at de samarbeider, er at de vil få tilgang til studenter og ansatte ved universitetene. Tilgang til ny kunnskap er også et viktig motiv, og det er også behovet for å forbedre ferdighetene hos egne ansatte.

- En stor andel av bedriftene peker også på omdømmemessige hensyn som viktige for samhandlingen.

- Undersøkelsen viser at samarbeidet skjer gjennom en rekke kanaler. Når det gjelder forskning, er felles forskningsprosjekter det som angis som den viktigste formen, deretter konsulentoppdrag eller kontraktsforskning.

- Det er jevnt over noe flere bedrifter som samarbeider med universiteter om undervisning, enn det er bedrifter som samarbeider om forskning. Dette gjelder samarbeid om praktikant- og lærlingordninger for studenter, gjennom gjesteforelesninger, ved ordninger knyttet til rekruttering av nye kandidater, og til opplæring av ansatte eller medarbeidere i bedriften. En av fem av de som samarbeider med universiteter og høgskoler, oppgir også at de deltar i pensumutvikling.

- En siste form for samhandling, som også er omfattende, er knyttet til universitetets bredere samfunnsoppdrag. Dette kan handle om samarbeid omkring felles arrangementer som konferanser eller seminarer.

- Bedriftene ble også spurt om hvilke universiteter de samhandlet mest med. I overkant av en firedel av bedriftene som har kontakt med universiteter, oppga NTNU som sin viktigste partner. Etter NTNU var det ingen som skilte seg ut, de resterende universitetene var omtrent like. Det vil si at de store universitetene som Bergen og Oslo ikke samarbeider med flere bedrifter enn de mindre universitetene.

Når det skilles på hvilken region bedriften ligger i, viser undersøkelsen imidlertid at Universitetet i Agder ligger fremst. Hele $79 \%$ av bedriftene på Agder oppgir UiA som sin viktigste partner. Undersøkelsen viser også at gjennomgående samarbeider bedriftene klart mest med universiteter $i$ sin egen region, men det er variasjoner regionene imellom. 
Resultatene fra undersøkelsen er viktige, ikke bare fordi man her får bildet tegnet fra bedriftssiden, men også ved at de viser at samarbeidet omfatter en hel rekke områder, og at undervisningsrelatert virksomhet er såpass omfattende.

\section{Kapittel 8}

Kapittel 8 tar også for seg universitetets regionale engasjement, men spør her om dette blir en atskilt tredje rolle, eller en rolle som er integrert i kjernevirksomhetene utdanning og forskning. Forfatteren utprøver regionalt engasjement empirisk i en regional kontekst og gjennom en konkret case. Fokus i casestudien er hvordan regionalt engasjement tolkes i institusjonens strategiplaner, og hvordan dette har vært fulgt opp gjennom konkrete handlinger.

Innledningsvis presenteres en drøfting av begreper som omhandler relasjonen mellom universitetet og omgivelsene og begrepet regionalt engasjement relatert til ulike former for kunnskap.

Casen som er valgt, er Universitetet i Agder (UiA). Denne er valgt, dels fordi den representerer et av de nye universitetene i Norge, og dels fordi UiA siden begynnelsen av 200o-tallet eksplisitt har arbeidet med å konkretisere det regionale engasjementet. Dataene som analyseres, er hovedsakelig skriftlige kilder i form av strategiplaner for perioden 1995 til 2019. For den siste delen av perioden, 2017 og 2018, er analysene også bygd på intervjuer, observasjon og aktiv deltakelse.

Kapitlet beskriver en utvikling av det regionale engasjementet i strategiplanene. Utgangspunktet i den første planen er en vekt på autonomi og en lineær forståelse av den daværende Høgskolen i Agders rolle. Regionen blir sett som kilde til problemstillinger og datatilfang for forskningen. Utviklingen går videre til en stadig bredere forståelse og et ønske om å bli et forbilde for hvordan en utdannings- og forskningsinstitusjon kan bli en aktiv medspiller i egen region. Begreper som innovasjon og entreprenørskap, næringsrelevant forskning, kunst og kulturelle ytringer, velferd og demokrati tas i bruk. Det snakkes om medskaping, og signalet er at tiden som passiv observatør til den regionale utviklingen er over. Slik går planene fra fase til fase, fram til den siste planen som analyseres, 
der begrepet samskaping står sentralt, og der det regionale engasjementet er viet stor plass. For denne perioden (2017-2018) er det også analysert noen tiltak spesielt rettet mot samskaping i regionen. De illustrerer tiltak både i kjernevirksomheten og i den eksisterende virksomheten mot samfunnet rundt. Avslutningsvis reises spørsmålet om en organisering knyttet til den akademiske kjernen er mer hensiktsmessig med tanke på kunnskapsutvikling og institusjonalisering for samskaping enn de mer dekoplede modellene som ofte ellers er i bruk.

\section{Kapittel 9}

Utgangspunktet for dette kapitlet er at et høyere utdanningssystem kan ses som ulike kombinasjoner av en hierarkisk orden, der akademisk status avgjør rangering mellom institusjonene, og en organisk orden, der relasjonene mellom institusjonene blir definert av ulike funksjoner eller oppgaver gjennom spesialisering. I tillegg defineres et system av høgskolers og universiteters relasjon til staten og til samfunnet.

Begrepet «det geografiske paradigmet» står sentralt i kapitlet. Dette paradigmet blir, som vi har sett i flere av de andre kapitlene, tydelig ved etableringen av distriktshøgskoler. Det innebærer

- at utdanning blir en rettighet som gjøres gjeldende også for ungdom i nasjonens periferier.

- at utfordringer knyttet til rekruttering av kompetansearbeidskraft over hele landet må løses regionalt.

- utvikling av en ny høgskolekultur der akademikere utvikler kunnskap med utgangspunkt i regionene.

Det pekes videre på noe som også kommer fram i flere av de andre kapitlene, at det oppsto et krysspress mellom en arbeidsdeling basert på regionale forskjeller og ulike regionale mandat, og en fagutvikling basert på akademisk kompetanse og konkurranse.

I dette kapitlet står relasjonen mellom institusjonene i det norske universitets- og høgskolesystemet i fokus. Utgangspunkt tas i en beskrivelse av utviklingen mellom institusjoner i Nordland og Nord-Norge, og da 
spesielt relasjonen mellom Høgskolen i Nesna og Høgskolen i Bodø (fra 2011 Universitetet i Nordland) fram mot en fusjon av disse institusjonene til Nord universitet i 2016.

Høgskolen i Nesna var i utgangspunktet en såkalt provinsskole, etablert som lærerutdanning i 1918 for å bøte på lærernøden i fylket. I Bodø ble Statens lærerskoleklasser etablert som et krisetiltak i 1951. I tiden som fulgte, hadde disse to institusjonene en arbeidsdeling seg imellom, Nesna utdannet lærere for fådelte skoler i Bygde-Norge, mens elevene i Bodø fikk en utdanning mer tilpasset sentrale strøk. Kapitlet følger så relasjonen mellom disse institusjonene gjennom de ulike reformene som fulgte.

Etableringen og utviklingen av distriktshøgskole i Bodø falt sammen i tid med åpningen av Universitetet i Tromsø. Nordland distriktshøgskole (NDH) vokste raskt, og det gikk ikke lenge før det ble konkurranse mellom NDH og UiT om studentene fra Nordland fylke. Etter hvert ble det konkurranse om lokalisering av ulike høyere utdanningstilbud i NordNorge, og Nordland distriktshøgskole vant flere av disse.

Ved høgskolereformen, der regionale høgskoler ble fusjonert, fikk Nordland fylke beholde tre høgskoler, den i Nesna, Høgskolen i Bodø, som nå var blitt Høgskolesenteret i Bodø, og Høgskolen i Narvik. Kapitlet viser hvordan reformene påvirket Nesnas kamp for sin eksistens. Underveis hadde kampens kjerne beveget seg fra kravet om å skaffe distriktene motekspertise til kravet om å bevare institusjonens selvstendighet. Ulike strategiske grep ble gjort for å ivareta dette. Samtidig vises det i kapitlet hvordan de ulike strukturendringene som kom, nye perspektiver på organisering og ledelse, den økende vekten på forskning, internasjonalisering og kvalitetssikring, og institusjonens egne strategiske grep for å møte dem, skapte store utfordringer for Høgskolen i Nesna. Det gjorde også utviklingen ved Høgskolen i Bodø, spesielt dennes ønsker og arbeid for å bli akkreditert som universitet, der målet ble endelig oppnådd i 2011.

Det geografiske paradigmet kom mer og mer under press. Vekt på universiteters og høgskolers bidrag til økonomisk vekst i regionene og kvalitet $\mathrm{i}$ utdanning, forskning, utviklingsarbeid og innovasjon innebar en $ø k t$ tendens til regional sentralisering. Dette utfordret også Høgskolen i Nesna fordi denne skolens fokus mer var rettet mot bevaring av små lokalsamfunn enn regional vekst og økonomisk utvikling. 
Strukturreformen, som flere tidligere kapitler har omhandlet, beskrives her som karakterisert av et nytt paradigme som sprengte seg vei, og som samtidig langt på vei sprengte det geografiske paradigmet. Dette betegnes som det akademiske paradigmet. Akademisk kvalitet og status ble førende for fusjonsprosessene, samtidig som den hierarkiske orden slo ut den organiske orden.

Strukturreformen medførte at Høgskolen i Nesna, sammen med Høgskolen i Nord-Trøndelag, i 2016 ble fusjonert med Universitetet i Nordland til Nord universitet. Dermed var Høgskolen i Nesna historie. Men kampen om campus på Nesna ble videreført innenfor det nye universitetet.

\section{Kapittel 10}

Kapittel 10 er avslutningskapitlet. Her tegnes de historiske og geografiske rammene om utviklingen av den regionale høyere utdanning og forskning i Norge opp på en litt annen måte enn det er gjort i flere av de foregående kapitlene. Med støtte i den britiske statsviteren Mark Bevirs tredelte fasemodell for de vestlige lands samfunnsutvikling, der det skilles mellom en nasjonsbyggingsfase, en fase for velferdsstatsutbygging og en fase for den neoliberale og nettverkende stat, argumenterer forfatteren for at utviklingen av høyere utdanning og forskning har skjedd tilpasset disse fasenes ulike krav og muligheter. Dette har gitt en regional struktur som i noe er lik den utviklingen vi har sett i andre land, men som særlig i sin geografiske utstrekning mot overgangen mellom velferdsstatsfasen og den neoliberal stat, nådde en grad av desentralisering som var særegen for Norge, og som best kan forklares gjennom den regionale dimensjonens plass som metapolitisk føring i vårt land.

Kapitlet samler opp i seg mye fra de diskusjonene som er ført i de foregående kapitlene. Samtidig reiser det også spørsmål ved om den geografiske konsentrasjonen av UH-strukturen som skjer fra 1990-tallet og fremover, er bærekraftig fra et videre politisk perspektiv. I en tid der staten reorganiserer den regionale forvaltningsstrukturen både på fylkesog kommunenivå, stiller den kun noen få, overordnede krav til denne reorganiseringen, og da først og fremst knyttet til skala og effektivitet. Staten opptrer slik ut fra et regionalliberalistisk ståsted, der kunnskap om 
og hensyn til regionalt nedarvede tradisjoner, sammenhenger og spenninger spiller en underordnet rolle. Det samme gjelder for reorganisering av UH-sektoren. Staten opptrer slik eksplisitt geografiløst og overlater til aktørene selv å finne fasit for den geografiske strukturen som skal gjelde for fremtiden.

Denne posisjonen er historisk sett eksepsjonell, og står også i skarp motsetning til den detaljstyring av den regionale strukturen som Gudmund Hernes sto for som sektorens statsråd noen tiår tidligere. Begge posisjoner, den overdrevne dirigisme og den geografiløse regionalliberalisme, har skapt utfordringer og konflikter. Flere av disse er beskrevet i dette og i de foregående kapitlene. Akkurat nå er regionalliberalismens følger mest i fokus, slik det er beskrevet i makro i dette kapitlet og i mikro med utsiktspunkt Nesna i kapittel 9.

Det åpne spørsmålet som reises til slutt i kapitlet, er om regionalliberalismen er bærekraftig for et samfunn som grunnleggende er konstituert ved kompromisser mellom sterke regionale interesser. I forlengelsen av dette kommer det spørsmålet som ikke er stilt, men som kapitlet åpner for: Hva slags styringsideologi følger dersom den nytente regionale bevisstheten vi i dag ser blomstre, også kommer i posisjon til å legge sine premisser for UH-sektoren?

\section{Referanser}

Bull, T. (1980). For å si det som det var. Oslo: Cappelen.

Johnsen, H. C. G. (2014). The new natural resource. Knowledge development, society and economics. Farnham: Routledge.

Knudsen, J. P. (2018). Towards a new spatial perspective - Norwegian politics at the crossroads. Norsk Geografisk Tidsskrift - Norwegian Journal of Geography, 72(2), $67-81$.

Rokkan, S. (1967). Geography, religion and social class: Crosscutting cleavages in Norwegian politics. I Lipset, S. M. \& Rokkan, S. (Red.), Party systems and voter alignments: Cross-national perspective (s. 367-444). New York: The Free Press.

Slagstad, R. (1998). De nasjonale strateger. Oslo: Pax. 


\title{
Instrument eller institusjon? Skiftende politiske prioriteringer
}

\author{
Per Olaf Aamodt \\ NIFU - Nordisk institutt for studier av Innovasjon, Forskning \\ og Utdanning \\ Lars Lyby \\ NIFU - Nordisk institutt for studier av Innovasjon, Forskning \\ og Utdanning
}

\begin{abstract}
In Norway, as in all other industrialised countries, a strong expansion in higher education started in late 1950s. This was politically initiated with the aim of a better educated work-force and also broadening access to higher education socially and regionally as well as by gender. In the late 1960s a major reform was initiated in Norway to establish alternatives to universities to handle the expected growth. A new non-university, geographically spread sector was created with the clear aim of stimulating development in all corners of the country.

The present chapter analyses the shifting policies for the regional roles of higher education institutions as stated in central policy documents. During the last 50 years higher education policy has been drawn between their regional roles and institutional concentration. Many colleges have been merged into a few large multi-campus institutions, leaving the impression that the aims of world-class quality and excellence have replaced the regional role. However, most of the campuses that existed before 1990 still exist within new institutional settings.

The original rationale behind a geographically spread institutional structure is less visible in today's policy, but at the same time the regional role of higher education has become broader and perhaps even more important. Back in the 1960s the objectives were mainly enrolling local students, educating the local workforce and the direct effects of the institution. This is still the case, but gradually $\mathrm{R} \& \mathrm{D}$ activities and innovation have become important contributions of higher education institutions.
\end{abstract}

Keywords: educational expansion, higher education, regional policy, institutional pattern

Sitering av dette kapitlet: Aamodt, P. O., \& Lyby, L. (2019). Instrument eller institusjon? Skiftende politiske prioriteringer. I J. P. Knudsen \& T. Lauvdal (Red.), Geografi, kunnskap, vitenskap. Den regionale UH-sektorens framvekst og betydning (s. 25-52). Oslo: Cappelen Damm Akademisk. https://doi.org/10.23865/noasp.73.ch1. Lisens: CC BY 4.0 


\section{Innledning}

Det er solid dokumentert at universiteter og høgskoler spiller en viktig rolle for samfunnsutviklingen. Særlig siden siste halvdel av 1950-tallet har dette blitt vektlagt i stadig sterkere grad, noe som faller sammen med endringer i samfunn og arbeidsliv og den sterke veksten i høyere utdanning. Når universiteter og høgskoler dermed gis et økende samfunnsansvar, vil dette også gjelde for den regionen de er lokalisert i.

Regionale hensyn var på 1960-tallet en viktig begrunnelse for både etableringen av Universitetet i Tromsø og høgskolesektoren - spesielt distriktshøgskolene. Desentralisering av høyere utdanning ble sett på som et viktig distriktspolitisk virkemiddel, ikke minst fordi Distrikts-Norge hadde vansker med å rekruttere høyt utdannet arbeidskraft (Kyvik, 1981; Kyvik, 1999). Målet om lik rett til utdanning og å utjevne de regionale forskjellene var også et viktig premiss: Økte lokale utdanningstilbud ville kunne tiltrekke seg studenter gjennom økt tilgjengelighet, og i neste omgang bidra til at flere høyt utdannede ville bosette seg i regionen. Temaet er fortsatt aktuelt, ikke minst i forbindelse med strukturreformen, men den politiske virkeligheten og begrepsbruken har endret seg betydelig. En sentral del av den planlagte presentasjonen vil derfor være å analysere hvordan mål og virkemidler har endret seg over tid, basert blant annet på en gjennomgang av de mest sentrale NOU-ene og stortingsmeldingene. Universiteter og høgskoler bidrar til sine regioner på mange ulike måter (Arbo (i denne boka); Sæther mfl., 2000; Heggen, 2014; Fulsås, 1993). I dette kapitlet reiser vi spørsmålet om hvordan den regionale betydningen av høyere utdanning har blitt vektlagt i utdanningspolitikken, med hovedfokus på perioden fra og med 1960-tallet.

Universitets- og høgskolesektoren har både i Norge og ellers i Europa tradisjonelt vært kjennetegnet av en utpreget autonomi, ikke minst knyttet til hvordan primærfunksjoner som forskning og utdanning er blitt praktisert og utviklet. Friheten fra ytre innblanding - libertas academica - har vært en sentral selvreferanse og et adelsmerke for høyere utdanningsinstitusjoner siden tidlig opplysningstid. Samtidig har også disse institusjonene i moderne tid løpende vært gjenstand for styring og intervensjon, med henblikk på å skulle realisere politisk fastsatte mål 
om for eksempel økt utdanningsnivå i befolkningen eller større bredde i UH-sektorens utdanningstilbud. Med henvisning til Rómulo Pinheiro kan vi i denne sammenhengen sondre mellom institusjon og instrument, hvor vektleggingen av universiteter og høgskolers eksterne ytelser, som for eksempel deres økonomiske og regionale betydning, medierer et instrumentelt perspektiv på institusjoner. På den andre siden har man forestillingen om utdanninginstitusjoner som selvorganiserende enheter med sine særegne, indre liv og logikker, noe Pinheiro med referanse til blant andre Merton kaller et institusjonelt perspektiv (Pinheiro, 2016, s. 36-37). Dette kapitlet er basert på sentrale policy-dokumenter om høyere utdanning, spesielt offentlige utredninger og stortingsmeldinger. NOU-ene er innspill fra utvalg eller komiteer og ikke nødvendigvis et uttrykk for regjeringens politikk, men danner likevel et viktig grunnlag for politikkutformingen slik den kommer til uttrykk i stortingsmeldingene. Dessuten er stortingsmeldingene ofte mer tilbakeholdne med å flagge politiske prioriteringer. Vi har prioritert dokumenter som danner grunnlag for sentrale reformer fra 1960-tallet til i dag, og ser spesielt etter uttrykk for den regionale rollen til universiteter og høgskoler, men også mer generelle mål for den samfunnsmessige rollen til høyere utdanning.

\section{Fram mot 1960-tallet}

Før Universitetet i Oslo ble etablert i 1811, studerte norske studenter i hovedsak ved Universitetet i København. Universitetet i Oslo forble Norges eneste universitet fram til Universitetet i Bergen ble etablert i 1948, men i mellomtida var det opprettet flere høgskoler (Norges landbrukshøgskole i 1897, Norges tekniske høgskole i 1910, og Norges Handelshøyskole i 1936). Helt fram til midten av 1900-tallet var høyere utdanning i Norge tallmessig temmelig marginalt. Det var først på slutten av 180o-tallet at studenttallet passerte 1500, og veksten var fortsatt relativt moderat helt fram til midten av 1950-tallet. Deretter ser vi en meget rask vekst, i forhold til 1960 ble studenttallet ved universitetene doblet i 1965 og tredoblet i 1970. Etter 1975 stagnerte veksten ved universitetene en del år, mens veksten foregikk ved høgskolene. 


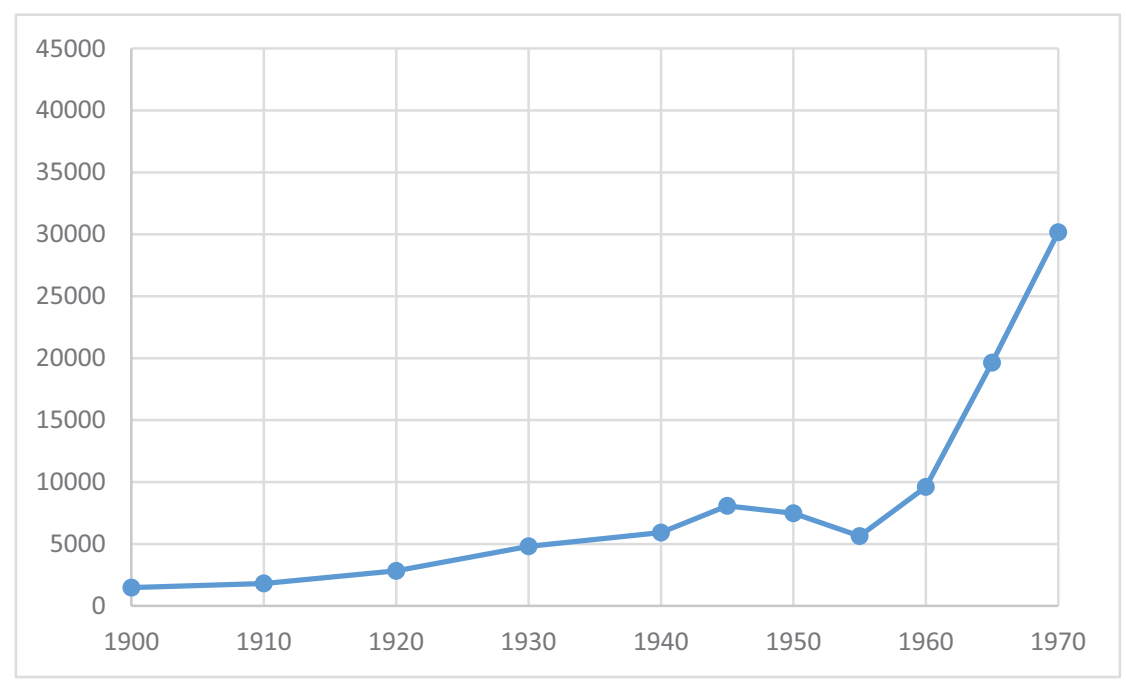

Figur 1. Studenter ved universiteter og vitenskapelige høgskoler 1900-1970.

En viktig forutsetning for veksten i studenttallene var en sterk utbygging av videregående utdanning (gymnaset). Antall artianere økte fra $3750 \mathrm{i}$ 1955 til 5179 i 1960, med en enda sterkere vekst fram til 1965. Dessuten kom i 1969 lov om 9-årig grunnskole, som ga en enklere vei til gymnasutdanning uten å gå veien om realskolen.

Til tross for lave studenttall var man på 1930-tallet opptatt av faren for overproduksjon av akademikere. Slik var det også i de første årene etter 1945, da gjenoppbyggingen etter krigen ble prioritert og høyere utdanning ikke var noe stort satsningsområde. Men det skjedde samtidig noen viktige ting på slutten av 1940-tallet med opprettelsen av Statens lånekasse, som ga økte muligheter for ungdom også fra alle samfunnslag til å finansiere sine studier, og studentsamskipnaden, som har hatt stor betydning for velferdstilbud for studentene.

I løpet av 1950-tallet snur oppmerksomheten fra en fare for overproduksjon til faren for mangel på akademikere. I 1954 tok Forskningsrådenes fellesutvalg initiativ til en utredning av behovet for kandidater. I rapporten, som forelå i 1957 (Forskningsrådenes fellesutvalg, 1957), ble det gjort inngående beregninger for de enkelte akademikergruppene. Hovedkonklusjonen var at utviklingen pekte i retning av et generelt underskudd av universitets- og høgskoleutdannet personale, og at denne mangelen vil 
gjøre seg gjeldende på nesten alle fagområder. Rapporten knytter disse beregningene til viktige samfunnsendringer, som $ø \mathrm{kt}$ behov for spesialutdannet arbeidskraft i servicesektoren og intimt knyttet til industrialiseringsprosessen og økning i levestandard. Vider sies det at Norges $ø$ konomiske posisjon internasjonalt bare kan bevares gjennom økt vekt på kvalitet. Rapporten fikk betydelig oppmerksomhet, og ble fulgt opp i en egen stortingsmelding (Kirke- og undervisningsdepartementet, 1957).

Oppmerksomheten på at høyere utdanning spiller en viktig rolle for utviklingen i samfunnet, er av relativt ny dato, og kommer for alvor inn i politikken på slutten av 1950-tallet. Erkjennelsen som vokste fram på siste halvdel av 1950-tallet om behovet for å øke kapasiteten i høyere utdanning, er ikke noe særnorsk fenomen, og ble understøttet av teorien om kompetanse som «den tredje faktor» og den såkalte humankapitalteorien. Schultz (1961) viste at utdanningsnivået $\mathrm{i}$ et land kan forklare en betydelig del av veksten i BNP. Dessuten viste Mincer (1962) og Becker (1964) hvordan individenes inntekter over livsløpet øker med økende utdanning, noe som tolkes som forskjeller i de ansattes produktivitet. Dette ble etter hvert brukt som en politisk begrunnelse for å investere i utdanning i mange land. Da Sovjetunionen i 1957 lyktes i å sende opp sin første satellitt, Sputnik, sendte det dessuten ut sjokkbølger som førte det til at Vesten rettet søkelyset mot å forbedre sine utdannings- og forskningssystemer for ikke å bli hengende etter i den teknologiske utviklingen.

Da Universitets- og høyskolekomiteen (Kleppe-komiteen) la fram sin innstilling i $1961 \mathrm{og}$ pekte på behovet for vekst i norsk høyere utdanning, var studenttallene allerede på rask vei oppover. Mange faktorer førte til en slik vekst, ikke minst utbyggingen av videregående skoler over hele landet, og velstandsøkningen gjorde at det ble mer attraktivt og tilgjengelig å ta skolegang ut over den obligatoriske folkeskolen. Kleppekomiteen diskuterte lokaliseringen av høyere utdanning, men skrev ikke noe eksplisitt om den regionale rollen til høyere utdanning. Men med sine forslag som la grunnlaget for ekspansjonen i høyere utdanning, la de også indirekte føringer for en desentraliseringspolitikk. Litt senere ble det med utgangspunkt i Ruud-komiteen (1965) vedtatt å opprette et universitet i Tromsø, noe som bidro til for alvor å sette distriktspolitiske mål 
for utdanningspolitikken. Et viktig premiss for å opprette Universitetet i Tromsø var å etablere medisinerutdanning for å bedre tilgangen på leger i Nord-Norge.

\section{0-tallet: vekst og reformplaner}

Før 1970 var det bare universitetene og de relativt små vitenskapelige høgskolene som ble regnet som høyere utdanning. Utviklingen i studenttallet er et resultat av politiske beslutninger om å satse på høyere utdanning, samtidig som veksten i seg selv bidrar til å endre karakteren av universitetene som institusjoner og deres samfunnsmessige rolle. Basert på beregninger fra Forskningsrådenes fellesutvalg utformet Kirke- og undervisningsdepartementet perspektivanalyser om fortsatt sterk vekst, men erkjente samtidig at en så sterk vekst ikke er realistisk innenfor rammene av de tradisjonelle universitetene. Dette er bakteppet for nedsettelsen av «Komiteen til å utrede spørsmål om videreutdanning for artianere og andre med tilsvarende grunnlag» (Ottosen-komiteen). Komiteen ble oppnevnt av regjeringen Gerhardsen 6. august 1965, men etter regjeringsskiftet foretok Borten-regjeringen oppnevning av flere nye medlemmer 3. desember samme år.

I mandatet ble komiteen gitt i oppdrag å utrede hvordan man kunne avlaste universitetene ved å opprette alternativer til de langvarige studiene. Det var også et sterkt politisk press på å bygge opp et større og mer variert utdanningstilbud i distriktene. Desentralisering av høyere utdanning ble betraktet som et viktig distriktspolitisk tiltak som kunne bidra til økt tilgjengelighet, og til at kandidatene vill bli værende i eget hjemstedsfylke (Kyvik, 1981).

Komiteen avla i alt fem delinnstillinger fra 1966 til 1970. I den første delinnstillingen fulgte de opp mandatet og skisserte hovedlinjene, og lanserte forslag om opprettelse og lokalisering av nye høgskoler. Komiteen tok som sitt utgangspunkt at det var viktig å dekke etterspørselen etter studieplasser ved å ekspandere høyere utdanning. De la til grunn beregninger av forventet artianerfrekvens, og anslo at studenttallet ville øke fra ca. 30000 til ca. 90000 i 1985, med en fordeling på 65000 i universiteter og (vitenskapelige) høgskoler og vel 23 ooo i annen postgymnasial 
utdanning. Komiteen konkluderte med at den ønskede og beregnede veksten i studenttallene ville være urealistisk innenfor rammen av de tradisjonelle universitetene. Komiteen sammenfattet i delinnstillingen problemet slik: Det må skaffes til veie et utdanningstilbud som er variert med hensyn til lengde, faglig innhold og geografisk plassering. Et viktig premiss var å kunne tilby studier for ungdom i alle deler av landet for å redusere de geografiske forskjellene i rekruttering. Komiteen argumenterte også for at utviklingen i distriktene var avhengig av økt utdanning i befolkningen, og foreslo en inndeling av landet i utdanningsregioner (som i hovedsak følger fylkesgrensene).

I delinnstilling nr. 2 fremmer komiteen forslag om å korte ned studiene innenfor universitetene. Som alternativer til de lange universitetsstudiene burde det utvikles kortere, mer yrkesrettede studietilbud i et system av distriktshøgskoler som skulle omfatte eksisterende yrkesutdanninger som bygger på examen artium, kortvarige utdanninger, samt nye former for postgymnasial utdanning. Komiteen argumenterer sterkt for denne samlingen av ulike postgymnasiale utdanninger i studiesentre (distriktshøgskoler). De påpeker at en slik utbygging må ses i sammenheng med den generelle distriktspolitikken, der et viktig trekk er å legge til rette for utviklingen av differensierte lokale kulturmiljøer. Slike studiesentre kunne bety en betraktelig økonomisk plussfaktor for de stedene der de blir etablert, til å trekke til seg og holde på særlig kvalifiserte fagfolk, og til å utnytte de begavelsesressursene som finnes i distriktene. De nye studiesentrene skal også utvikle studietilbud som er alternative til universitetene og høgskolene og utdanne personell det er behov for i distriktene. Ottosen-komiteen framhever ellers en rekke mulige distriktspolitiske effekter av etableringen av distriktshøgskolene.

Mange av komiteens forslag møtte motstand, både fra studenter, universitetsansatte og fra profesjoner og profesjonsutdanningene. Men forslaget om å opprette distriktshøgskoler ble fanget opp politisk, og både storting og regjering ønsket å starte opp med en begrenset prøvedrift med distriktshøgskoler som et nytt, selvstendig skoleslag. Komiteen fikk i oppdrag å utrede dette nærmere, og endret på sine planer for delinnstilling 3 , som opprinnelig skulle ha behandlet etter- og videreutdanning. 
I delinnstilling nr. 3 kommer komiteen med nærmere forslag til hvordan distriktshøgskolene kan organiseres og administreres. De fastholder fortsatt at «Med en distriktshøgskole mener komiteen en organisatorisk sammenbygging av en rekke kortere postgymnasiale utdanningsenheter innenfor en nærmere definert region». Komiteen lister opp en rekke eksisterende utdanninger som de mener kan innpasses i et distriktshøgskolesystem, blant annet lærerutdanningene, sosialarbeiderskolene og tekniske skoler. Det ble parallelt også utredet nye studietilbud, blant annet i økonomisk-administrative fag. Utover å omtale utdanningsregionene foreslo ikke komiteen konkrete lokaliseringer.

Kirke- og undervisningsminister Kjell Bondevik tok kort tid etter den tredje komitéinnstillingen initiativ til å utrede prøvedrift med distriktshøgskoler med sikte på oppstart allerede høsten 1969. Dette utløste en rekke lokale initiativ. Underveis mottok departementet en rekke henvendelser og utredninger om etablering av en distriktshøgskole i deres distrikt, og med tilbud om tomter og boliger for studenter og ansatte. Når så departementet fremmer Stortingsproposisjon 136 (1968-69) om prøvedrift med distriktshøgskoler har de gått bort fra forslagene fra Ottosenkomiteen om en samling av eksisterende utdanninger, og foreslår isteden å starte opp med skoler som i første omgang bare omfatter et nytt toårig $ø$ konomisk/administrativt studium. Bakgrunnen for dette er sterk motstand mot å integrere de ulike studiene i felles institusjoner. Satsningen på økonomisk-administrative fag ble av departementet begrunnet med at dette var kompetanse som ville være nyttig for distriktene. Departementet foreslo å lokalisere de tre første skolene til Stavanger, Kristiansand og Molde, men ga også bevilgninger til økonomisk/administrativ undervisning i Trondheim og Skien. Det ble vedtatt å ta opp 150 studenter til det første studieåret ved de første tre skolene. Et viktig utgangspunkt var at både Stavanger og Kristiansand lenge hadde arbeidet aktivt for å få et universitet $\mathrm{i}$ byen, et arbeid som viste seg å bære frukter ved at to av de tre første distriktshøgskolene ble lokaliser der.

I innstillingen fra kirke- og undervisningskomiteen kom det dissenser om å opprette en distriktshøgskole i Telemark fra 1969, eller om man burde vente et år, og om man ikke burde binde seg til å velge Molde i Møre og Romsdal. 
I Stortingsdebatten 20. juni var enkelte fra opposisjonen noe betenkt over den partielle løsningen som var valgt. I debatten var det svært mange av representantene som tok ordet, men de aller fleste var opptatt av hvor de skulle lokaliseres, det vil si i deres valgdistrikt. Det kom også mange innspill om at det burde etableres en skole i et bygdemiljø, noe som trolig bidro til at Bø i Telemark fikk en av de neste høgskolene. Flere representanter var ellers opptatt av at distriktshøgskolene ikke måtte bli annenrangs utdanningsinstitusjoner. Det er liten tvil om at forslaget om distriktshøgskoler ble møtt med stor regional entusiasme, og at byene og lokalsamfunnene som fikk skoler, la forholdene til rette for dem. Noe av entusiasmen henger også sammen med at skolene ble rent statlig finansiert, mens det i Ottosen-komiteen ble antydet at også fylkene skulle bidra i finansieringen. (Framstillingen er basert på Vollset \& Aamodt, 1972.)

Med etableringen av distriktshøgskolene og Universitetet i Tromsø på slutten av 1960-tallet fikk høyere utdanning i Norge en ny og viktig regionalpolitisk rolle som man i ettertid må bedømme som vellykket. Høyere utdanning tok på en måte hele landet i bruk, regionene sluttet opp om sine skoler, og de sterke regionale skillelinjene i rekrutteringen av studenter ble over tid redusert.

\section{Sammenheng mellom regionalpolitikk og utdanningspolitikk}

Distriktspolitiske hensyn og argumenter spilte som nevnt en viktig rolle for etableringen av distriktshøgskolene. Lokaliseringsdebattene var viktige, og fra mange hold ble det framhevet at skolene ville kunne spille en viktig rolle i utviklingen av distriktene, på tilsvarende måte som ved etableringen av Universitetet i Tromsø. De regionalpolitiske målene for høyere utdanning og vedtaket om å opprette distriktshøgskoler har dermed nær sammenheng med den generelle regionalpolitikken eller distriktspolitikken. Det er mulig å se dette ut fra to synsvinkler: for det første om den generelle distriktspolitikken inneholdt henvisninger til høyere utdanning, og for det andre i hvilken grad distriktspolitiske hensyn var førende for utviklingen i høyere utdanning. 
På 1950-tallet ble det foretatt store industriutbygginger, og såkalte hjørnesteinsbedrifter ble etablert med statlige midler i en rekke utkantstrøk for å skape arbeidsplasser og beholde bosettingen i distriktene. Allerede i 1952 kom den første Nord-Norge-planen. I 1961 ble Distriktenes Utbyggingsfond etablert som et virkemiddel til å støtte de delene av landet med fraflytting og svakt arbeidsmarked.

Satsning på høyere utdanning hadde ingen uttalt plass i 1950-tallets distriktspolitikk, denne koplingen kom først tydelig til syne i begrunnelsene for å etablere Universitetet i Tromsø i Ruud-komiteen i 1963, og ble enda sterkere betonet ved etableringene av distriktshøgskolene i 1970.

Distriktspolitikk sto sentralt på 1960- og 1970-tallet, men hadde endret seg fra 1950-tallets tro på storstilet statlig industriutbygging.

Et viktig mål for distriktspolitikken var å redusere flyttestrømmene fra de andre landsdelene til de sentrale delene av Østlandet, og de viktigste virkemidlene var å påvirke disposisjonene til det private næringslivet (Brofoss, 1965). I Stortingsmelding nr. 39 (1967-68) skisseres at det er statens oppgave å legge til rette for at det innenfor norsk industri bygges opp 20-30 administrative miljøer av høy kvalitet og tilstrekkelig bredde. Rundt 1970 ble det laget en rekke nye regionalpolitiske planer, såkalte landsdelsplaner, utarbeidet av egne komiteer. Noen av disse, men ikke alle, var opptatt av utdanning generelt og av høyere utdanning spesielt.

I 1969 kom en innstilling fra Østlandskomiteen (Kommunal og arbeidsdepartementet 1969). Denne innstillingen sa imidlertid ingenting om betydningen av utdanning.

I 1972 kom landselsplanen for Nord-Norge, der drøfting av utdanning, inklusive høyere utdanning var viet betydelig plass. Bakgrunnen for dette var at det var et lavt utdanningsnivå i arbeidsstyrken, og at rekrutteringen til videregående og høyere utdanning var svak (NOU 1972: 33). Et eget utvalg i landsdelskomiteen, ledet av Anders Madslien, avga en egen innstilling om utdanningsoppgavene i Nord-Norge, som dannet utgangspunkt for et kapittel om utdanning og kultur i landsdelsplanen for NordNorge. Det påpekes her at den videregående skolen har blitt utbygd forholdsvis raskt i Nord-Norge, og at antall gymnasiaster øker forholdsvis raskere enn i landet sett under ett. Det påpekes videre at både Universitetet i Tromsø og den øvrige postgymnasiale utdanningen (Nordland 
Distriktshøgskole, lærerskolene og Narvik tekniske skole) er i rask vekst. Utvalget hevder ellers at «Universitetet i Tromsø er kanskje den største enkeltoppgave som det noen gang er gjort vedtak om å gjennomføre i Nord-Norge». Men den videre utbyggingen av universitetet må skje forholdsvis raskt. Samtidig pekes det på at vekstimpulsene av universitetet for landsdelen - utover de rent lokale - ikke vil komme av seg selv. Uten en bestemt styringsstrategi kan man risikere at effektene av universitetet i for stor grad blir konsentrert om Tromsøregionen.

Et av de sentrale problemene i Nord-Norge var (og er) lærermangelen, og utvalget peker på at en «meget stor del av den undervisningen som gis i ungdomsskolen i fag som norsk og matematikk, nå gis av lærere uten fullverdig utdanning i disse fagene». Kirke- og undervisningsdepartementets prognoser pekte i retning av snarlig balanse, men disse syntes å være basert på feilaktige forutsetninger. Utvalget mener at utdanningen av lærere må økes på landsbasis, og det er nødvendig å bygge ut lærerutdanning i Finnmark og i Harstad/Sortland.

Mens utviklingen i videregående utdanning er tilfredsstillende, mener komiteen at de postgymnasiale tilbudene er få og med plass til for få studenter.

I landsdelsplan for Agder og Rogaland (NOU 1973: 28) pekes det på at landsdelen har et relativt godt utbygd postgymnasialt utdanningstilbud, men at det må bygges ut i takt med antall studiesøkende. Komiteen finner det ikke realistisk å fremme krav om et særskilt, tradisjonelt universitet i regionen i planleggingsperioden, men å satse på de to distriktshøgskolene og den øvrige postgymnasiale utdanningen. Men komiteen hevder også sterkt at landets femte universitet, når det kommer, må lokaliseres i Agder/Rogaland. Samtidig påpeker komiteen viktigheten av å utvikle forskningen i regionen. Forskningen må planlegges og koordineres innenfor regionen, og det bør opprettes egnede organer for utvikling av forskningsvirksomheten.

Mens landsdelsutvalget for Nord-Norge gir klart uttrykk for hvilken betydning de ser av høyere utdanning for utviklingen i regionen, er dette mindre framtredende i landsdelsplanen for Agder og Rogaland og fraværende i Østlandskomiteens innstilling. Vi har ikke vurdert nærmere årsaker til denne forskjellen i vektlegging av høyere utdanning. 


\section{Utvikling av høgskolesektoren 1970-1987. Fra Ottosen til Hernes}

Istedenfor planene om regionale studiesentre som skulle omfatte alle eksisterende studietilbud i regionen, ble distriktshøgskolene et eget skoleslag med en utdanningsprofil som ble utvidet i flere retninger etter de første $ø$ konomisk/administrative studiene. Etter at de tre første distriktshøgskolene be etablert i 1969, vedtok Stortinget i 1970 å etablere tre nye skoler, Bø i Telemark allerede samme år, og så Hedmark/Oppland og Nordland.

I 1973 la regjeringen Korvald fram en egen stortingsmelding der de vurderer alle Ottosen-komiteens fem innstillinger samlet (Kirke- og undervisningsdepartementet, 1972-73). I denne meldingen om den videre utbygging og organisering av høyere utdanning avvises en samling av all høyere utdanning i regionale studiesentre. I stedet for regional sentralisme bør man satse på spredning av høyere utdanningsinstitusjoner til forskjellige steder i regionene innenfor de enkelte fylkene som egne utdanningsregioner. Etter regjeringsskiftet trakk regjeringen Bratteli denne meldingen tilbake og la fram en ny melding (Kirke- og undervisningsdepartementet, 1974-75) der de støtter Ottosen-komiteens forslag om en geografisk konsentrasjon. Utviklingen gikk likevel ikke slik, og stortingsflertallet støttet opprettelsen av nye utdanningstilbud på nye lokaliteter. Stortingsmelding nr. 17 støttet forslaget om å betrakte all utdanning utover gymnaset som høyere utdanning (Kyvik, 1999), og etter hvert ble all postgymnasial utdanning oppgradert til høgskoleutdanning. Helsefagene var sist ute, i 1981, da de ble overført fra Helsedepartementet til Kirke- og undervisningsdepartementet.

En ny og sterkt voksende høgskolesektor ble således etablert ved siden av universiteter og det som etter hvert ble betegnet som vitenskapelige høgskoler. Målet om å dempe veksten i universitetene ble realisert, og det meste av veksten skjedde i høgskolene. Det ble innført stillingsstopp ved universitetene, og fra 1974 flatet studenttallene ut og holdt seg helt stabilt på rundt 40 ooo i mer enn ti år. I samme periode vokste antall høgskolestudenter fra ca. 25 ooo til nærmere 60 ooo, og i 1981 passerte høgskolene universitetene i studenttall. Ottosen-komiteens måltall om 90 ooo studenter i 1985 ble passert allerede i 1983, og det som i 1965 trolig framsto som lite sannsynlig, viste seg å bli en sjeldent treffsikker prognose. 
På slutten av 1980-tallet får vi en ny sterk vekst i studenttallene ved universitetene, og så en ny utflating etter 1996. Etter 2000 skyldes den nye sterke veksten i universitetssektoren at tidligere høgskoler blir oppgradert til universitetsstatus.

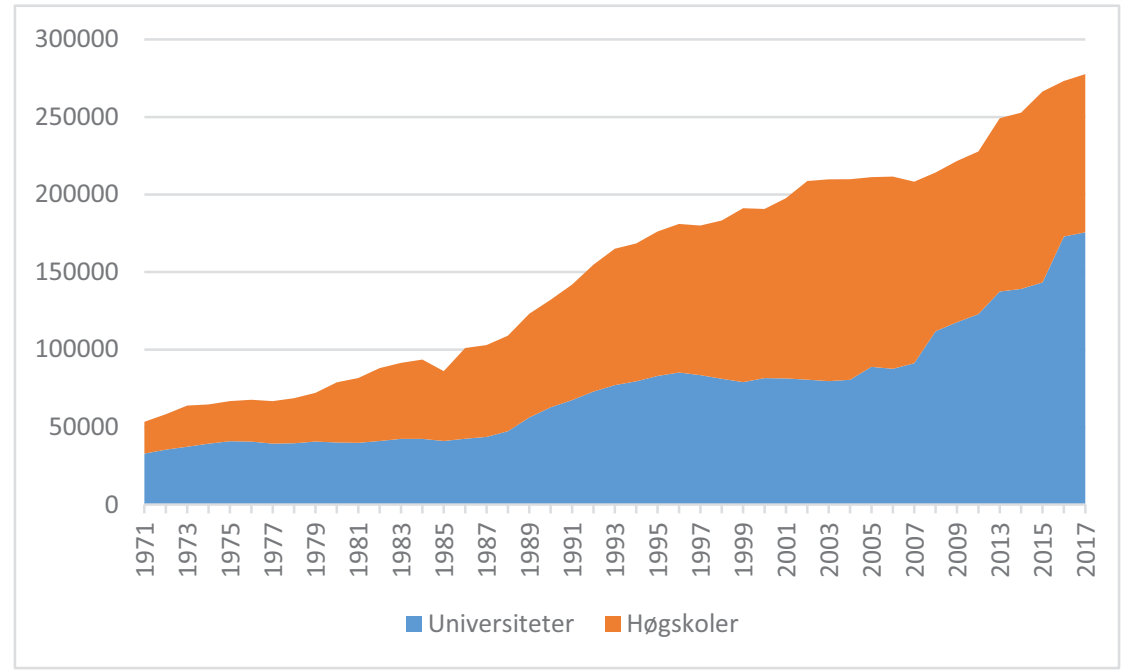

Figur 2. Studenter ved universiteter og høgskoler 1971-2017.

Selv om distriktshøgskolene vokste fra under 1000 studenter i 1971 til ca. 10 ooo på slutten av 1980-tallet, utgjorde de ikke mer enn ca. 15 prosent av det samlede antallet høgskolestudenter, men andelen øker til ca. 20 prosent fram til distriktshøgskolene opphører som egen kategori med Høgskolereformen i 1994. En betydelig del av veksten etter 1980 skjedde for øvrig ved private høgskoler, spesielt BI. Selv om vi finner de fleste studentene i de større byene, var det blitt et omfattende tilbud av høyere utdanning i alle fylker.

Hele 1970-tallet var preget av en sterk distriktslinje i høyere utdanning, men på 1980-tallet ble det reist spørsmål om den store spredningen av studietilbud. Daværende statsråd Einar Førde mente da at vi nærmet oss en grense for desentralisering og ressursbruk i høyere utdanning. Han etterlyste:

... ein debatt om når desentralisering går over til å bli meir oppflising enn reell desentralisering. Samstundes er det igjen tid for å ta fram det gamle spørsmålet om kva som er minste kritiske masse, scerleg for utdanningsinstitusjonar i eit lite land som er avhengig av at forskningsmiljøa og undervisningsmiljøa er breie nok 
til at vi kan halde oppe internasjonal kvalitet. (Stortingets budsjettdebatt høsten 1980, sitert etter Skoie, 1988)

Senere statsråd Lars Roar Langslet uttrykte seg i samme retning som Førde. Det kom også påstander om at Norge hadde verdensrekord i høgskoler. Satsningen på nye regionale høgskoler ble dempet, men samtidig sto ønsket om ytterligere utbygging i distriktene sterkt i Stortinget (Skoie, 1988). Kirke- og undervisningskomiteen mente i 1987 at det bør finnes utdanning i ingeniørfag, økonomisk-administrative fag og helsefag $i$ alle regioner. Denne spenningen mellom spredning og konsentrasjon dannet noe av bakteppet da Hernes-utvalget ble nedsatt i 1988.

Fra Ottosen-komiteens og departementets side var det ikke intensjonen at distriktshøgskolene skulle drive forskning, selv om ansettelseskravene var de samme som ved universitetene. På grunn av stillingsstoppen ved universitetene var det mange nyutdannede akademikere som søkte seg til stillinger ved distriktshøgskolene, og de ønsket å ha de samme vilkårene for å drive forskning som ved universitetene. Utviklingen av forskningsvirksomhet var dermed i stor grad drevet fram av personalet ved distriktshøgskolene, men forskningsvirksomheten var lav ved de andre høgskolene. Etter hvert aksepterte da også Stortinget at forskning kunne finne sted.

Med utviklingen av distriktshøgskolene ble det etter hvert etablert en rekke regionale forskningsenheter. Disse var ikke tilknyttet høgskolene, men sprang likevel ut fra dem. Den første av disse forskningsstiftelsene var Rogalandsforskning allerede i 1973. Nordlandsforskning kom i 1979. Møreforskning i 1980, Østlandsforskning i 1984 og Telemarksforskning i 1986. Det lå forventninger om at denne forskningen skulle være nyttig for regionen, og dermed vokser det fram en ny regional rolle for høyere utdanning, en rolle som tidligere ikke var blitt vektlagt i distriktspolitikken. Etter hvert spilte også Universitetet i Tromsø en viktig regional rolle med sin forskning.

\section{Regionale, internasjonale og globale? 1987 til i dag Hernes-utvalget}

Nyttårsaften 1986 trykker Dagbladet en kronikk av professor Gudmund Hernes, «Kan man ha ambisjoner i Norge?», der han retter søkelyset mot 
kvaliteten i norsk høyere utdanning. Dette er startskuddet til en omfattende debatt, og 22. juli 1987 oppnevner Kultur- og vitenskapsdepartementet et nytt universitetsutvalg med den samme Gudmund Hernes som leder. Et viktig bakteppe er en erkjennelse av at Norge da hadde om lag 200 institusjoner i høyere utdanning, der tre firedeler av dem hadde mindre enn 400 studenter. Utvalget ble blant annet bedt om å vurdere økonomiske og kvalitetsmessige konsekvenser av en slik struktur, og om å fremme «... formene for samarbeid, arbeidsdeling og konkurranse mellom institusjonene ...».

Hernes-utvalget la fram sin innstilling i september 1988, og samler sine forslag i fem hovedpunkter:

- Tiltak for å fremme rekrutteringen til høyere utdanning. Utvalget anslo behov for 105000 studieplasser fra 1995.

- Arbeidsdeling og samarbeid gjennom «Norgesnettet». De foreslo å redusere antall høgskoler til ca. 50, og ikke å etablere flere nye universiteter.

- Styrke norsk forskning, og bedre finansiering for hovedfagsstudenter og stipendiater.

- Øke indre produktivitet gjennom ny personalpolitikk, større og mer hensiktsmessige faglige enheter, styrke faglige lederfunksjoner og minst 5 prosent realvekst de nærmeste årene.

- Utvikling av livslang læring

Hernes-utvalget holder langt på vei fast ved flere av hovedtankene i innstillingen fra Ottosen-komiteen, men peker på at det finnes behov for en ytterligere sentrering av de regionale utdanningsinstitusjonene. På den ene siden går bekymringen på at forskning og utdanning med de mange høgskolene blir for spredt og lokalt innadvendt uten at de får øye på tilsvarende utdannings- og forskningsmiljøer som finnes andre steder i landet. På den andre siden uttrykker utvalget også en frykt for at dette i sum kan svekke den samlede nasjonale forskningsinnsatsen, med mange små miljøer som hver især forsøker å bli selvforsynt på hele bredden av utdanningsfeltet uten muligheter eller ambisjoner om å utvikle spesialiserte forskningsfelt. Med mobilisering av begreper om «integrerte 
nettverk», «knutepunkt» og «forbindelseslinjer» foreslår utvalget at regionene i større grad dyrker mere spesialiserte og spissede forskningsinteresser med henblikk på å skape et «vitalt sammenfelt nasjonalt system av samvirkende institusjoner» (Hernes et al., 1988, s. 109).

Hernes-utvalgets utredning blir fulgt opp med en ny stortingsmelding, St.meld. 40 (1990-91) Fra visjon til virke. Departementet mente at antall institusjoner burde reduseres ytterligere enn det Hernes-utvalget foreslo, og i arbeid med St.meld. 40 fikk de laget en egen utredning (Bakken \& Hveding, 1991). De mente at antallet burde ligge på mellom 20 og 30.

I tråd med Hernes-utvalget fastslår St.meld. 40 (1990-91) at regionene i større grad burde «konsolideres» og spesialiseres fremfor å konkurrere i bredden med alle andre regioner. Men alle regioner kan ikke uten videre få oppfylt sine ønsker. De sentrale utdanningsmyndigheter skal fortsatt ha det grunnleggende ansvar for nasjonal prioritering og koordinering når det gjelder å etablere og eventuelt nedlegge studier. En slik prioritering vil nødvendigvis måtte medføre at alle dagens studietilbud ikke kan gis overalt.

Igjen påpekes det også at de mange små miljøene svekker mulighetene til å etablere robuste forskningsmiljøer, og at mange små høgskoler ofte er lite rasjonelle i drift, har svak utbygd administrasjon og gir dårligere utnytting av faglige ressurser enn større institusjoner.

Disse betraktningene vitner om en endring av perspektivet på de regionale utdanningsinstitusjonene, der deres forsknings- og utdanningsvirksomhet for første gang settes i sammenheng med et mål om en nasjonal integrering av all forskning og utdanning, med sikte på å løfte nivået i hele landet. Samtidig fastholdes oppmerksomheten på utdanningsinstitusjonenes betydning for regionene.

Stortinget gir sin tilslutning til hovedprinsippene i St.meld. 40 (199091), og departementet arbeider videre med en ny høgskolereform som Stortinget slutter seg til i 1993, og som iverksettes fra 1994. Nesten 100 høgskoler slås da sammen til 26 statlige høgskoler. Reformen fører til samlokalisering av en del studietilbud, men flere av de eksisterende studiestedene blir opprettholdt ${ }^{1}$. 


\section{Mjøs-utvalget og Kvalitetsreformen}

Når det ble nedsatt et nytt utvalg for høyere utdanning allerede 10 år etter Hernes-utvalget, hang det mye sammen med at universiteter og høgskoler lenge hadde ønsket større autonomi i faglige og administrative spørsmål. Dessuten var det mye som tydet på at målene om bedre gjennomføring av studiene, som sto sentralt i både Ottosen-komiteen og Hernes-utvalget, ikke var innfridd. Mjøs-utvalget ble oppnevnt i april 1998 med et svært bredt mandat, et mandat som ikke presenterte noen klar «diagnose» slik mandatet til Hernes-utvalget formulerte. Utvalget skulle

- gi en samlet framstilling av utviklingen i høyere utdanning sett i lys av de siste ti års utdanningsreformer med spesiell vekt på kvalitet og effektivitet

- vurdere behov for endringer ut fra sektorens lovpålagte oppgaver i lys av nye krav fra studenter, samfunns- og næringsliv

- vurdere behov for endringer som følge av økt internasjonalisering

- vurdere dimensjoneringen i et langsiktig perspektiv og vurdere rekruttering i lys an demografiske forhold

- vurdere strategier og vilkår for omstilling ved institusjonene

- vurdere sammenhengene mellom utdanningssystemet og arbeidslivet

- vurdere gradsstrukturen og utviklingen av studietilbudene

- vurdere insitamentsstrukturen, bl.a. prinsippet for finansiering

- vurdere rammene for oppdragsvirksomhet

Utvalgets innstilling forelå i mai 2000, og kom med svært mange gjennomgripende forslag i gradsstruktur, vektlegging av undervisningsog veiledningsformer, institusjonsstruktur og akkrediteringsformer, institusjonenes tilknytning til staten, finansiering og intern styring og organisering. Innstillingen møtte mye kritikk og debatt, men svært mange av forslagene ble fremmet i stortingsmeldingen og senere vedtatt i Stortinget.

I Mjøs-utvalgets utredning finner vi en klar videreføring av et økonomisk rasjonale, der høyere utdanning i distriktene sammenstilles med de regionale arbeidsmarkedenes behov og muligheter for vekst. Høyere utdanningsinstitusjoner skal fortsatt være en pådriver i styrkingen av 
kompetanse i regionenes arbeidsmarked. Dette understrekes blant annet gjennom å peke på hvilke kvaliteter som potensielt ligger i regionale høgskoler og universiteters betydning for lokal næringsutvikling. Denne $ø$ øonomiske kodifiseringen av en regionalt forankret universitets- og høgskolepolitikk kan vi gjenfinne i utpekningen av følgende regionale idealer for høyere utdanningsinstitusjoner. Basert på en utredning om høgskolenes regionale betydning påpeker utvalget at institusjonene i høyere utdanning kan fungere som sentre til å bistå regionene, tiltrekke seg og holde på kompetansekrevende virksomheter, styrke det regionale tilbudet av høyt kvalifisert arbeidskraft og fungere som sosiale og kulturelle samlingssteder.

I Mjøs-utvalget vies mye oppmerksomhet til hvordan regionale universiteter og høgskoler kan bidra til å skape lokal næringsvekst og sikre kvalifisert arbeidskraft ute i distriktene. Universiteter og høgskoler skal muliggjøre regionenes økonomiske bærekraft og utvikling. Men i St. meld. nr. 27 (2000-2001) om Kvalitetsreformen nevnes ikke den regionale rollen til universiteter og høgskoler (Kirke-, utdannings- og forskningsdepartementet, 2000-01).

Ett av de viktigste elementene i Kvalitetsreformen var at høgskoler kunne gis status som universitet etter nærmere bestemte kriterier og etter akkreditering av NOKUT. Universitetet i Stavanger ble opprettet i 2005, Universitetet i Agder i 2007, og Universitetet i Nordland i 2011.

\section{Stjernø-utvalget og strukturreformen}

På bakgrunn av utviklingen i norsk høyere utdanning siden Høgskolereformen i 1994 og etter Kvalitetsreformen i 2003 ble et nytt utvalg oppnevnt 24. mai 2006 for å vurdere den videre utviklingen av norsk høyere utdanning. Utvalget skulle ta utgangspunkt i universitetenes samfunnsrolle, og Soria Moria-erklæringen om å styrke det regionale universitets- og høgskolesystemet. Mandatet var å vurdere tiltak for å sikre at strukturen av universiteter og høgskoler skulle svare på en rekke utfordringer om kvalitet $\mathrm{i}$ utdanning og forskning, blant annet å sikre samspill med lokalt og regionalt samfunnsliv, sikre tilførsel av kvalifisert arbeidskraft, dekke etterspørselen etter studieplasser, sikre god regional balanse i studietilbud og kompetanse, skape livskraftige institusjoner og robuste fagmiljøer og god utnytting av samfunnets ressurser. 
Stjernø-utvalget la fram sin innstilling 22. januar 2008. En av utvalgets diagnoser er at svakheten med strukturen i det norske universitetsog høgskolesystemet er at den framstår som fragmentert, med et stort antall små institusjoner og fagmiljøer som konkurrerer med et fåtall større institusjoner om studenter, personale og faglig prestisje. «Det er flere utfordringer knyttet til dagens institusjonsstruktur og styringssystem $i$ høyere utdanning $i$ forhold til universitetenes og høyskolenes regionale rolle. Mange institusjoner er ikke robuste nok til å håndtere de samlede virkningene av skjerpet konkurranse som følge av demografiske endringer og urbaniseringsprosesser, eller forventningene om økt internasjonalisering og om å bidra mer til utviklingen av regionen. De er for små til å kunne omstille seg, og forventningene fra ledelsen er ofte svake eller utydelige» (NOU 2008:3 (Stjernø-utvalget)).

Utvalget drøfter flere alternative modeller for en ny struktur for norsk høyere utdanning, men faller ned på det de kaller «flercampusmodellen». All statlig høyere utdanning i Norge samles i 8-10 flercampusuniversiteter med tyngdepunkt i ulike deler av landet.

I Stjernø-utvalgets utredning finner vi en klar kontinuitet fra Hernes-utvalgets råd om å konsolidere og slå sammen utdanningsinstitusjoner i regionene, nettopp for å styrke fagmiljøene og unngå utdanningstilbud som forblir bleke kopier av hverandre, uten noen samhandling eller muligheter for å styrke hverandre. I den forbindelse blir også det «regionale mandatet» til utdanningsinstitusjonene, altså deres tilførsel av kompetanse til omgivelsene, nå betinget av at kvaliteten er tilstrekkelig høy, og at fagmiljøene er robuste.

Stjernø-utvalgets forslag møtte motbør, og ble ikke vedtatt, selv om det var politisk støtte til hovedmålene. Departementet under den rød-grønne regjeringen valgte heller en "frivillighetslinje», der de anmodet institusjoner om å slå seg sammen og satte av midler til prosessene (SAK). Flere institusjoner utredet muligheter for sammenslåing, og noen ble realisert (bl.a. mellom Universitetet i Tromsø, Høgskolen i Tromsø og Høgskolen i Finnmark, og mellom høgskolene i Oslo og Akershus, senere universitetet OsloMet). Regjeringen Solberg med statsråd Torbjørn Røe Isaksen ønsket likevel å framskynde konsentrasjonsprosessen, og la fram stortingsmeldingen Konsentrasjon for kvalitet, Meld. St. 18 (2014-2015). Både 
underveis i arbeidet med stortingsmeldingen og etter vedtok flere institusjoner å slå seg sammen:

- Høgskolene i Vestfold og Buskerud og senere også Høgskolen i Telemark (senere Universitetet i Sørøst-Norge

- Høgskolene i Hedmark og Lillehammer til Høgskolen i Innlandet (har søkt akkreditering som universitet)

- Høgskolene Stord/Haugesund, Bergen og Sogn og Fjordane

- NTNU og høgskolene i Sør-Trøndelag, Ålesund og Gjøvik

- Universitetet i Nordland med Høgskolen i Nesna og Nord-Trøndelag til Nord universitet

Det norske institusjonslandskapet har dermed endret seg mye. Av offentlige institusjoner var det i 20034 universiteter, 7 vitenskapelige høgskoler og 25 statlige høgskoler, mens det i 2018 var 10 universiteter, 5 vitenskapelige høgskoler og 5 statlige høgskoler. I tillegg kommer en statlig kunsthøgskole, tre private vitenskapelige høgskoler og 13 private høgskoler, de fleste svært små.

I dag er nesten alle institusjonene flercampusinstitusjoner, men dette er ikke noe nytt. Slik sett er mye av den modellen som Stjernø-utvalget foreslo, blitt realisert, selv om konstellasjonene er blitt en del annerledes på veien. Så langt har ikke fusjonsprosessene ført til reduksjon i antall studiesteder.

Samtidig som strukturreformen hadde konsentrasjon som sitt mål, ble det lagt stor vekt på institusjonenes regionale rolle. Det legges vekt på at UH-sektoren skal sikre arbeidskraft i distriktene og bidra til å styrke lokalt næringsliv, osv., selv om dette her ikke er et primært omdreiningspunkt. Selv om en av strukturreformens erklærte mål er «regional utvikling», legges det i liten grad vekt på å synliggjøre hvordan reformen eventuelt skal bidra til å styrke regionene. De regionale universiteter og høgskoler har ikke lenger en «primærfunksjon» som økonomiske pådrivere, men blir nå i økende grad hektet opp på høyere utdanning som et globalt system, som blant annet skal svare på forventninger om «robusthet», internasjonaliserte fagnettverk og publikasjoner i internasjonale tidsskrift.

Vi finner altså en dreining som ikke kommer til syne som et markant brudd med de tidligere dominerende forestillingene om 
utdanningsinstitusjonenes regionale betydning, men ved at forventningene til de regionale utdanningsinstitusjonenes «vitenskapelighet» og akademiske nivå blir mere markant fremtredende. Selv om forestillingen om universitets- og høgskolesektoren som en særlig drivkraft i regionene fortsatt er til stede, betones det i mindre omfang utover på 9o- tallet og fremover. Den direkte koblingen mellom forskjellige kompetansebehov i distriktene og utdanningsinstitusjonene som primærleverandør av disse kompetansene, havner etter hvert noe i bakgrunnen for mer forskningsstrategiske vurderinger. Formulert annerledes ser det ut til at den direkte betydningen av utdanningsinstitusjonenes noervor i regionene blir viet mindre politisk oppmerksomhet. De regionale utdanningsinstitusjonene tillegges ikke i like stor grad en regional primærfunksjon, tvert imot blir det nå avgjørende at de skal komme utover sin «regionalitet» og lokale forankring som utdanningsinstitusjoner; de skal være internasjonalt orienterte og omstilles til å drive mer med forskning. Dette betyr ikke at det regionale spørsmålet forsvinner, men at rammen rundt de politiske diskusjonene om regionale utdanningsinstitusjoner blir foldet inn i en generell forskningspolitisk optikk, og i noe avtagende grad en instrumentell distriktspolitisk optikk.

Etter 2000 ser vi samtidig konturene av et nytt argument, som forsøker å aksentuere det internasjonale konkurranseaspektet i UH-sektoren, iakttatt gjennom globaliseringens prisme. Dette blir også fremført i forbindelse med forventninger og krav til de regionale institusjonene. I Konsentrasjon for kvalitet, Meld. St. 18 (2014-2015), heter det for eksempel at «universiteter og høyskoler er regionalt forankret, men det er ikke ensbetydende med å vore en lokal eller regional institusjon. Institusjonene må vore internasjonalt orienterte og konkurransedyktige innenfor sine faglige prioriterte områder. Likeledes finnes det mange eksempler på norske bedrifter som er regionalt forankret, men konkurrerer $i$ et globalt marked. Disse trenger samarbeidspartnere som kan bidra med kunnskap og kompetanse for global konkurransekraft» (Kunnskapsdepartementet, 2014-2015, s. 20). Her ligger det altså en oppfordring til de regionale utdanningsinstitusjonene om at de i større grad bør forme sitt selvbilde og modellere sine virkefelt etter de nye betingelsene frembrakt av den globale tidsalderens æra, med alt hva det innebærer av radikalt nye vilkår for konkurranse 
om forskere, forskningsmidler, prestisje, oppmerksomhet og studenter. Hvorvidt et slikt bilde i noen grad rent faktisk sammenfaller med virkeligheten, er naturligvis en annen sak.

\section{Avsluttende diskusjon En politikk for vekst}

I dette kapitlet har vi gått gjennom hvordan regionalpolitiske mål er blitt formulert i politikken for høyere utdanning siden 1960-tallet. Den regionalpolitiske dimensjonen har vært til stede i hele perioden, men har endret karakter i takt med vekst og endringer i høyere utdanning og i samfunnet. Det har funnet sted både reelle endringer og endringer i språkbruk. Mens «distriktspolitikk» var et sentralt begrep på 1960- og 70-tallet, er dette erstattet med «regionalpolitikk». Vi skal ikke her gå nærmere inn på de reelle endringene i denne politikken, de reflekterer selvsagt de store endringene som har skjedd i denne perioden i næringsstruktur, næringspolitikk og ikke minst i utdanningssystemet.

Det er få samfunnssektorer som kan oppvise en lignende vekst som universiteter og høgskoler, selv om noe av veksten skyldes at det først var etter 1970 at en rekke eksisterende utdanninger ble definert som høyere utdanning. Fra ca. 10 ooo studenter ved universiteter og høgskoler har tallet vokst til over 250 ooo i dag, en vekst som også henger sammen med at nesten all ungdom begynner i videregående opplæring. I denne perioden har Norge gått fra å være et utdanningsfattig til et utdanningsrikt system (Aamodt \& Stølen, 2003). Politikken for vekst ble utformet rundt 1960, og ble begrunnet ut fra at høyere utdanning var viktig for samfunnsutviklingen, og at arbeidslivet ble stadig mer kompetansebasert (Grøgaard \& Aamodt, 2006). Kandidater med høyere utdanning fant seg jobber i stadig nye deler av arbeidsmarkedet.

\section{Desentraliseringspolitikk}

Kjølen til vårt moderne masseutdanningssystem i høyere utdanning ble strukket på 1960-tallet, og Ottosen-komiteen var her helt sentral. Komiteen framhevet behovet for vekst, men at en slik vekst ikke kunne ivaretas 
innenfor de etablerte universitetene. I tråd med utviklingen i mange andre land ble det skapt alternativer til universitetene ved høgskoler som ble etablert i alle deler av landet. Denne politikken var også et eksplisitt uttrykk for å utjevne forskjeller mellom landsdelene både med hensyn til rekrutteringen av studenter og av kvalifisert arbeidskraft. Etableringen av Universitetet i Tromsø og det nye høgskolesystemet utformet som følge av Ottosen-komiteens forslag ble betraktet som viktige virkemidler til en slik utjevning. Et viktig element i denne politikken ble etablering av distriktshøgskoler i omtrent alle fylker, med unntak av der hvor det fantes et universitet, og som sammen med et stort antall høgskoler for utdanning av bestemte yrker (f.eks. lærere, sykepleiere, ingeniører, og sosialarbeidere) utgjorde en desentralisert høgskolesektor. Denne desentraliserte strukturen bidro positivt til rekrutteringen av studenter og overfor arbeidsmarkedet, samtidig som institusjonene i seg selv hadde viktige ringvirkninger.

\section{Samordning av et fragmentert system}

Mange av høgskolene var små, og på 1980-tallet kom det flere innspill om mer konsentrasjon. Men Stortinget ville fortsette en desentraliseringslinje, og mente for eksempel at man burde ha tilbud om ingeniørutdanning i alle fylker. I 1987 nedsatte Kultur- og vitenskapsdepartementet et nytt utvalg for høyere utdanning - Hernes-utvalget. Mandatet framhevet behovet for økt kvalitet, og påpekte problemet med det store antallet små institusjoner, og ba om en utredning av en struktur med bedre samarbeid og arbeidsdeling.

Hernes-utvalget framhever den store satsningen som er gjort, og framveksten av et system som ivaretar sterk vekst. Men de konstaterer også at institusjonsstrukturen har utviklet seg i en motsatt retning av det Ottosen-komiteen anbefalte, og støtter at en nedre grense på 500 studenter ville være et fornuftig tall. Det er til sammenligning interessant å merke seg at i Strukturmeldingen (Meld. St. 18 (2014-2015)) er det nedre tallet satt til 5000.

Hernes-utvalget er mest opptatt av å konsentrere og finne samarbeidsformer for å bedre kvaliteten, og sier lite om distriktspolitikk, men skriver at utdannings- og forskningspolitikken må ses som en del av distriktspolitikken, og at et spredt utdanningstilbud er viktig for å sikre 
kompetanseutviklingen i alle deler av landet. De foreslår ikke konkret å legge ned studiesteder, men dette kan sies å ligge innbakt i forslag om samlokalisering.

I motsetning til Ottosen-komiteen legger Hernes-utvalget stor vekt på forskningen. Dette reflekterer blant annet at spesielt distriktshøgskolene etter hvert bygde opp en økende forskningsvirksomhet. Dette bidrar igjen til at hensynet til en sterkere konsentrasjon av de faglige ressursene kommer mer i forgrunnen enn når en bare tar hensyn til undervisningen.

Alt i alt må en kunne si at den sterke vekten på distriktshensyn i politikken for høyere utdanning som kom klart fram på 1960- og 1970-tallet, måtte vike for økende oppmerksomhet om kvalitet, konsentrasjon og styringshensyn med Hernes-utvalget og i forberedelsene til Høgskolereformen i 1994. Høgskolereformen ble dessuten en integrert del av de statlige styringsreformene på 1990-tallet med vekt på målstyring, budsjettering, virksomhetsplanlegging, resultatrapportering, evaluering og statlig kontroll (Kyvik, 1999). Reformen var dermed ikke bare utformet som svar på utfordringer innenfor høyere utdanning.

I departementets retningslinjer for de nye institusjonene etter Høgskolereformen og i forarbeidene til en ny felles lov om høyere utdanning fastslås både retten og plikten til å drive FoU generelt, og ikke minst FoU som kan styrke næringsutvikling og offentlig sektor i regionene (Kyvik, 1999). Den direkte koplingen til distriktspolitikk er ikke lenger klart uttalt, men den regionale rollen og vekten på samfunnsrelevans for høgskolesektoren trekkes fram.

\section{Mot en ny struktur for høyere utdanning}

Bare få år etter Høgskolereformen nedsettes Mjøs-utvalget, som får et bredt og omfattede mandat. Et viktig utgangspunkt for dette utvalget var institusjonenes ønske om mer forvaltningsmessig autonomi og mindre departemental detaljstyring.

Mjøs-utvalget legger stor vekt på høyere utdannings rolle for samfunnet, men uten eksplisitte distriktspolitiske henvisninger. Den påfølgende stortingsmeldingen, som fremmer Kvalitetsreformen, nevner imidlertid ingenting om høyere utdannings samfunnsmessige rolle. I vår sammenheng er de viktigste sidene ved Kvalitetsreformen at høgskolene gis 
anledning til opprykk til universitetsstatus, og en sterk vekst i antall nye studieprogrammer både på lavere og høyere nivå.

Etter Kvalitetsreformen ble høgskolene i Stavanger, Agder og Nordland oppgradert til universitetsstatus, og i løpet av de senere årene har strukturreformen gitt Norge en helt ny institusjonsstruktur. Argumentene har i hovedsak vært å skape mer robuste fagmiljøer, men samtidig blir deres rolle for samfunnet og regionen framhevet. Det er verdt å merke seg at til tross for at antall institusjoner er redusert, består foreløpig de fleste av studiestedene.

\section{Er distriktspolitiske hensyn blitt mindre viktig?}

Tilsynelatende er dette riktig. Andre hensyn - kvalitet, effektivitet, konsentrasjon og styringsevne - har kommet mye mer i forgrunnen. Hensynet til å utjevne geografiske forskjeller veier ikke lenger tyngst. Det er ikke spesielt overraskende. Utviklingen av høgskolesystemet, sammen med etableringen av Universitetet i Tromsø - samt endringer i grunnopplæringen - har bidratt til å redusere de regionale forskjellene over tid. Trolig er dette også medvirkende til at en klar underrepresentasjon av kvinner er snudd til et klart overskudd. Ser vi høyere utdanning under ett, har det også skjedd en viss sosial utjevning. UH-politikken har med andre ord vært et vellykket instrument til å utjevne de regionale ulikhetene, og har dermed et stykke på vei overflødiggjort seg selv. Behovene for de spesifikt distriktspolitiske målene om rekruttering er dermed ikke til stede i samme grad som for 50 år siden, og dermed er også mange av argumentene for den desentraliserte institusjonsstrukturen svekket. Til tross for samlingen av høyere utdanning i færre og større institusjoner er det likevel fortsatt en sterk spredning av studiestedene, selv om det ble foretatt en del samlokaliseringer i forbindelse med Høgskolereformen i 1994, blant annet i Oslo og i Agder.

Selv om mange av de opprinnelig distriktspolitiske målene med høyere utdanning er langt mindre uttalt, har de ikke blitt borte, men har antatt nye former. Argumentene for at høyere utdanning skal bidra i samfunnsutviklingen generelt og i sine regioner, står minst like sterkt som for 50 år siden. Og gradvis har de politiske målene for høyere utdanning kommet til å omfatte et bredere spekter enn rekruttering: økt vekt på FoU som virkemiddel i regionene, samspill mellom UH og arbeidsliv og innovasjon. I 
et slikt perspektiv kan man kanskje si at de regionalpolitiske målene med høyere utdanning ikke er svekket, kanskje snarere tvert om, men de har antatt nye former.

Den regionale betydningen til høyere utdanning har våren 2019 kommet klarest til syne ved Nord universitet, der ledelsens forslag om å redusere antall studiesteder har vakt stort regionalt engasjement.

\section{Instrumentelle eller institusjonelle trekk}

Innledningsvis viste vi til Rómulo Pinheiro, som foretar en sondring mellom institusjon og instrument, der vektleggingen av universiteter og høgskolers eksterne ytelser, for eksempel deres økonomiske og regionale betydning, medierer et instrumentelt perspektiv på institusjoner. På den andre siden har man forestillingen om utdanninginstitusjoner som selvorganiserende enheter med sine særegne, indre liv og logikker, noe Pinheiro med referanse til blant andre Merton kaller et institusjonelt perspektiv (Pinheiro, 2016, s. 36-37). I den nyere utdanningspolitiske historien i Norge er det ikke mulig å identifisere en konsistent dikotomi, men vi kan se at begge disse oppfatningene kommer til syne med forskjellig tyngde på forskjellige tidspunkt i hele den norske etterkrigstiden frem til i dag. Vi kan derimot peke på at de politiske prioriteringene i denne perioden i økende grad blir opptatt av å skulle understøtte institusjonene i deres «indre liv» (forskning og utdanning), og at denne utviklingen kanskje er særlig markant i spørsmålet om UH-sektorens regionale betydning.

I løpet av 1980- og 90- tallet ser vi en utdanningspolitikk som i større grad ønsker å bidra til å fremme og høyne UH-sektorens institusjonelle primærfunksjon, i form av undervisning og forskning. Det instrumentelle blikket på UH-sektoren forsvinner ikke av den grunn, men den regionale og økonomiske betydningen av høyere utdanningsinstitusjoner blir betinget av at disse institusjonene samtidig holder et høyt faglig nivå. Det innebærer at det nå, i større grad enn tidligere, oppstår en politisk interesse for hvordan disse institusjonene kan bli bedre til å ivareta sin kjernefunksjon, altså hvordan universiteter og høgskoler kan bli bedre i sin forskning og undervisning. Grovt sagt og noe forenklet så finner 
vi en forskyvning i det politiske blikket på UH-sektoren, som i mindre grad utgår fra spørsmål om «hvordan UH-sektoren kan bidra til å realisere politiske mål for samfunnet?» og i større grad begynner å spørre «hvordan UH-sektoren kan bli bedre i sine grunnleggende funksjoner». Her ser vi også at politikken synes å «gjenoppdage» seg selv som sentral premiss for å kunne la institusjonene realisere sine primære funksjoner; politikken skal nå skape et best mulig grunnlag for at institusjonene skal skape seg selv som internasjonalt orienterte og konkurransedyktige institusjoner, både i undervisning og forskning. På den andre siden er det samtidig slik at det instrumentelle blikket, i form av lokale behov og UH-sektorens generelle rolle i regional utvikling osv., stadig er til stede i de politiske vurderingene av UH-sektoren.

\section{Referanser}

Aamodt, P. O. \& Stølen, N. M. (2003). Vekst i utdanningssystemet. I Statistisk sentralbyrå: Utdanning 2003 - ressurser, rekruttering og resultater. Statistiske analyser nr. 69.

Bakken, A. L. \& Hveding, E. (1991). Styringsordninger for regionale høgskoler. En utredning for Kirke-, utdannings- og forskningsdepartementet.

Becker, G. (1964). Human capital: Theoretical and empirical analysis with special references to education. Chicago: University of Chicago Press.

Brofoss, E. (1965). Distriktsutbyggingspolitikk. Bind I og II. Stensilerte forelesninger, Universitetet i Oslo, 1965.

Fulsås. N. (1993). Universitetet i Tromsø 25 år. Tromsø: Universitetet i Tromsø.

Grøgaard, J. B. \& Aamodt, P. O. (2006). Veksten i høyere utdanning: Noen drivkrefter og konsekvenser. I J. B. Grøgaard \& L. A. Støren (Red.), Kunnskapssamfunnet tar form. Utdanningseksplosjonen og arbeidsmarkedets struktur. Oslo: Cappelen Akademisk Forlag.

Kirke- og undervisningsdepartementet (1966-1970). Komitéen til å utrede spørsmål om videreutdanning for artianere og andre med tilsvarende grunnutdanning. Innstilling om videreutdanning for artianere m. v. (1-5). (Ottosenkomiteen). Oslo: Kirke- og undervisningsdepartementet.

Kirke- og undervisningsdepartementet (1957). Om tilgangen og behovet for akademisk arbeidskraft (Meld. St. 72 1957). Oslo: Kirke- og undervisningsdepartementet.

Kirke- og undervisningsdepartementet (1973-74). Om den videre utbygging og organisering av høyere utdanning (Meld. St. 66 1973-74). Oslo: Kirke- og undervisningsdepartementet. 
Kirke- og undervisningsdepartementet (1973-74). Om den videre utbygging og organisering av høyere utdanning (Tillegsmelding til Meld. St. 66 1973-74). Oslo: Kirke- og undervisningsdepartementet.

Kirke-, utdannings- og forskningsdepartementet (1990-91). Fra visjon til virke (Meld. St. 36 1990-91). Oslo: Kirke-, utdannings- og forskningsdepartementet.

Kirke-, utdannings- og forskningsdepartementet (2000-01). Gjør din plikt. Krev din rett (Meld. St. 27 2000-01). Oslo: Kirke-, utdannings- og forskningsdepartementet.

Kommunal- og arbeidsdepartementet (1969). Innstilling fra Østlandskomiteen.

Kunnskapsdepartementet (2014-15). Konsentrasjon for kvalitet (Meld. St. 18: 2014-15). Oslo: Kunnskapsdepartementet.

Kyvik, S. (1981). The Norwegian regional colleges. A study of the establishment and implementation of a reform in higher education. Rapport. Oslo: NAFVs utredningsinstitutt.

Kyvik, S. (Red.) (1999). Evaluering av høgskolereformen. Sluttrapport. Oslo: Norges forskningsråd.

Mincer, J. (1962). On-the-job training: Costs, returns and some implications. Journal of Political Economy $70(5)$ 2, 50-79.

NOU 1972: 33. (1972). Om landsdelsplan for Nord-Norge. Forslag til plan for utviklingen av landsdelen. Oslo: Miljøverndepartementet.

NOU 1973: 28. (1973). Om landsdelsplan for Agder og Rogaland. Forslag til plan for utviklingen av landsdelen. Oslo: Miljøverndepartementet.

NOU 1988: 28. (1988). Med viten og vilje (Hernesutvalget). Oslo: Kulturdepartementet.

NOU 2000: 14. (2000). Frihet med ansvar. Om høgre utdanning og forskning i Norge (Mjøsutvalget). Oslo: Kirke-, utdannings- og forskningsdepartementet.

NOU 2008: 3. (2008). Sett under ett. Ny struktur i høyere utdanning (Stjernøutvalget).

Pinheiro, R. (2016). Assessing change in higher education from the perspective of excellence versus relevance. Pathways through higher education research: A festschrift in honour of Peter Maassen (s. 37-40). Oslo: Universitetet i Oslo.

Schultz, T. (1961). Investment in human capital. American Economic Review, 51(5), 1-17.

Skoie, H. (1988). Offentlig politikk for universiteter og høgskoler 1945-1988 hovedtrekk. Vedlegg til NOU 1988: 28.

Sæther, B., Mønnesland, J., Onsager, K., Sørlie, K. \& Arboe, P. (200o). Høgskolenes regionale betydning (Vedlegg 9 i NOU 2000: 14).

Vollset, G. \& Aamodt. P. O. (1972). Distriktshøgskoler og samfunnsutvikling. Distriktspolitikk eller rasjonalisering av høyere utdanning (Hovedoppgave I sosiologi, Institutt for sosiologi). Oslo: Universitetet i Oslo.

Woodhall, M. (1992). Economic development and higher education. I B. Clark \& G. Neave (Red.), The encyclopedia of higher education vol 2. Oxford/New York/Seoul/ Tokyo: Pergamon Press. 


\title{
Regionale universiteter og utdanningspolitiske paradokser
}

\author{
Ivar Bleiklie \\ Universitetet i Bergen
}

\begin{abstract}
The chapter seeks to shed light on university reforms in Norway since 1980 and asks how well-designed the reforms are regarding their capacity to strengthen the impact of universities in the regions where they are located. The chapter starts by asking how well-suited universities are to meet the expectations they face in the regions where they are located. It argues that the institutions in many ways have organizational characteristics - as academic and bureaucratic organizations that are not well-suited to fulfilling varied and dynamic local needs. Subsequently the chapter analyzes the reforms and changes characterizing higher education - in terms of growth, internationalization and standardization - that may contribute to understanding the current situation. Finally, it takes a closer look at ongoing reforms and transformational processes and their indications of possible trends in the coming years. Here, changing expectations and tensions arising from multiple goals are emphasized in order to understand the obstacles faced by government attempts to enhance labor market relevance by means of structural reforms with institutional mergers as a main ingredient.
\end{abstract}

Keywords: higher education, policy, governance, systems, institutions, organizations

\section{Innledning}

Europeiske universiteter er innhentet av en ny virkelighet. Den kan beskrives gjennom flere forskjellige prismer som samlet og hver for seg viser omfattende endringer. Enten vi ser på vekst og tilgang til høyere utdanning, ledelse, organisering og styringsformer, undervisning og studiehverdag, forskning og annet akademisk arbeid eller universitetenes

Sitering av dette kapitlet: Bleiklie I. (2019). Regionale universiteter og utdanningspolitiske paradokser. I J. P. Knudsen \& T. Lauvdal (Red.), Geografi, kunnskap, vitenskap. Den regionale UH-sektorens framvekst og betydning (s. 53-74). Oslo: Cappelen Damm Akademisk. https://doi.org/10.23865/noasp.73.ch2.

Lisens: CC BY 4.0 
forhold til omgivelsene, møter vi grunnleggende, og i noen tilfeller revolusjonerende endringer.

I dette kapitlet skal jeg rette søkelyset mot noen av disse endringene med vekt på de offentlige universitetenes organisering og styringsformer og stille spørsmål ved hvor formålstjenlige de er med tanke på det som er denne bokens tema: universitetenes regionale betydning.

I den første delen av kapitlet skal jeg ta utgangspunkt i spørsmålet om hvor godt egnet dagens universiteter er til å innfri behov og forventninger som vi finner i de forskjellige regionene der de er lokalisert. Her vil jeg argumentere for at institusjonene på mange måter er organisert slik at de ikke vil være særlig innrettet på å møte varierte og skiftende lokale behov. Stikkord her er akademisering og byråkratisering. Deretter skal jeg analysere en del trekk ved de reformene og endringene som har preget høyere utdanning, og som kan bidra til å forklare dagens situasjon. Stikkord her er vekst, internasjonalisering og standardisering. Endelig skal jeg se nærmere på hva pågående reformer og endringsprosesser sier om mulige utviklingstrekk i årene som kommer, og her er stikkordene skiftende forventninger og spenninger mellom forskjellige mål. I den sammenheng peker to pågående utviklingstrekk seg ut: et forsterket fokus på arbeidsmarkedsrelevans og strukturreformer med sammenslåing av institusjoner som viktigste ingrediens.

\section{Regionale universiteter, statlige reformer og tre paradokser}

Kunnskapen om hvordan universiteter og høyere utdanningsinstitusjoner former og formes av de nære omgivelsene, er begrenset. La meg først si litt om noe av det vi vet.

I tillegg til at de er faglige institusjoner, er universiteter også byråkratiske organisasjoner (Mintzberg, 1979) med lange beslutningslinjer, hvis sentrale ressurs - fast ansatte i vitenskapelige stillinger - representerer langsiktige investeringer.

Samtidig er universitetene svært avhengig av omgivelsene (Bleiklie et al., 2015, 2017). Det er ikke først og fremst de nære regionale omgivelsene det er snakk om, men de nasjonale avhengighetene som er bygd inn 
i statlige finansierings- og evalueringsordninger, internasjonale avhengigheter (europeiske finansieringsordninger og reguleringer), internasjonale rankinger og faglige standarder utviklet av vitenskapelige disipliner. Potensielt kan finansielle avhengigheter utvikles lokalt og regionalt dersom det finnes aktører som har interesser og ressurser å sette inn på å etablere samarbeidsrelasjoner mellom universitetene og lokale aktører i offentlig eller privat sektor.

I tillegg er de behovene universitetene skal møte, svært varierte. En studie fra California (Scott \& Kirst, 2014) peker på at universiteter ikke er spesielt godt egnet til å innrette seg etter raske endringer i etterspørsel etter arbeidskraft og forskning. I California finnes det på den ene siden en dynamisk høyteknologisk sektor (jf. Silicon Valley) og på den andre siden mer stabile behov for eksempel knyttet til offentlige og private tjenester som helse og utdanning samt offentlig administrasjon. Raske endringer i utdanningsbehov ble i praksis møtt av andre tilbydere enn de store offentlige universitetene, i første rekke mindre, private aktører. Da ser jeg bort fra nettverket av høyteknologiske bedrifter i Silicon Valley og fremstående forskningsuniversiteter som Stanford University.

I Norge finnes det ikke et like variert og sammensatt høyere utdanningssystem som i California, og i praksis er de regionale universitetene og/eller statlige høgskolene noe nær monopolinstitusjoner i sine regioner. Det vil si at utdanningsinstitusjonene ikke er spesielt godt egnet til å reagere på behov og forventninger som kommer til uttrykk i dynamiske og omskiftelige markeder. Unntak finnes der spesielle industrinære teknologiske fagmiljøer har utviklet nære bånd til enkeltbedrifter, slik det er tilfellet i Horten og på Stord.

Endelig er de enkelte faglige miljøene innenfor høyere utdanning svært forskjellige og forholder seg til ulike aktører og miljøer i samfunnet. Mens noen tradisjonelt har tette forhold til arbeidslivet, har andre knapt direkte kontakt med aktører utenfor sitt eget fagfelt. Tette forhold til arbeidslivet er vanlig i profesjonsfag som medisin, sykepleie, jus og ingeniørfag,

Disse tre trekkene - standardisering, avhengighet av omgivelsene og varierte lokal- og fagmiljøer - gjør at det er gode grunner til å stille spørsmål ved hvor godt egnet norske universiteter og høgskoler er til å 
møte fremtidens behov for forskning og undervisning slik de fremstår i de regionene der de befinner seg. I forlengelsen av dette spørsmålet er det også nærliggende å spørre hvor godt egnet de siste årenes reformer er til å styrke institusjonenes evne til å bidra til og å styrke økonomi og offentlig tjenesteyting i sine egne regioner.

Hvilke relasjoner vil prege forholdet mellom institusjonene og egne regioner og lokalsamfunn? Jeg skal skissere noen utviklingstrekk som kan bidra til å kaste lys over spørsmålet. Det ene er et forsterket fokus på arbeidsmarkedsrelevans og yrkesretting av høyere utdanning. Det andre er sammenslåing av institusjoner til større flercampusinstitusjoner. Videre finnes det politiske føringer og insentiver som skal bidra til å utvikle fremragende miljøer med klare profiler. Endelig har det skjedd en sentralisering og standardisering av evaluerings- og akkrediteringsordninger, og ikke minst opptak av studenter til høyere utdanning, som synes å ha en rekke uintenderte, uforutsette og uønskete konsekvenser for utdanningsinstitusjonenes lokale/regionale tilpasning.

De senere årene har fokuset på arbeidsmarkedsrelevans blitt forsterket, og institusjonene har begynt å utvikle tiltak for å fremme relevans slik at de kan gi egnet utdanning til nye generasjoner av lokale studenter og forsyne bedriftene i regionen med etterspurt og velutdannet arbeidskraft. En grunn til dette er at Norge, som mange økonomisk avanserte land, har nådd et stadium der rundt $50 \%$ av hver ny generasjon tar høyere utdanning. Det er gode grunner for å bygge ut høyere utdanning, gitt at det er en klar statistisk sammenheng mellom utdanningsnivået $\mathrm{i}$ et land og $ø$ konomisk velstand, sosial velferd og graden av lykke befolkningen opplever. Derfor har også kapasitet og utbygging av høyere utdanning vært det dominerende perspektivet fra politikernes side siden begynnelsen av 1960-tallet, mens mindre oppmerksomhet har vært viet hvordan denne veksten burde fordeles på forskjellige utdanningsretninger. Dette kan illustreres med at det viktigste styringsredskapet til de sentrale myndighetene for dimensjonering av høyere utdanning, fastsetting av studieplasser ved den enkelte institusjon, stor sett har blitt brukt til å planlegge vekst. Det er først i de senere år at det har blitt foreslått nye og mer drastiske grep for å oppnå en bedre tilpasning mellom arbeidsmarkedets antatte behov og dimensjonering av høyere utdanning. Et av de første forslagene i 
den retning finner vi i Produktivitetskommisjonens første rapport (NOU 2015: 1). Her anbefaler kommisjonen mer håndfaste tiltak for å sikre: 1) at flere studenter ledes mot fagområder (teknologi) som det antas å bli størst behov for i kommende år, og bort fra studieplasser i humaniora og samfunnsvitenskap, 2) at studier og studiesteder med lav studentetterspørsel kan legges ned, 3) en overgang fra lange akademiske studier til kortere fagstudier og større satsing på kvalitet i høyere utdanning.

De problemstillingene kommisjonen tok opp knyttet til høyere utdanning og forskning, gjenspeiler tema som lenge hadde vært studert innenfor den litteraturtradisjonen som kalles «forskning om forskning» eller «Science and Technology Studies» (STS) (Gibbons et al., 1994; Nowotny et al., 2001). Denne litteraturen legger blant annet vekt på at høyere utdanning og forskning har blitt integrert i økonomi, politikk og samfunn på en helt ny måte når en stor del, om ikke et flertall, av nye rekrutter til arbeidsmarkedet har høyere utdanning og til dels forskningserfaring. Samtidig er stadig større deler av næringslivet avhengig av forskningskompetanse fordi de bruker eller produserer forskningsbaserte produkter (Bleiklie \& Byrkjeflot, 2002). Dette kommer tydelig til uttrykk i Produktivitetskommisjonens første rapport, som legger vekt på at kunnskap er samfunnets viktigste ressursgrunnlag for høy produktivitet, og at utdanningssystemet er det viktigste virkemiddelet for å påvirke «kunnskapskapitalen» (NOU 2015: 1, s. 338). Denne utviklingen betyr at høyere utdanning og forskning har blitt en stor offentlig sektor som naturlig utsettes for en helt annen oppmerksomhet fra politikere, media og samfunnet generelt enn bare for et tiår siden.

Det forsterkete fokuset på dimensjoneringen av høyere utdanning kan være utløst av at politiske aktører ser for seg at behovet for høyt utdannet arbeidskraft er i ferd med å mettes. Mange høyere utdanningssystemer ser ut til å bevege seg i den retningen, og i Danmark og Japan finner vi eksempler på at myndighetene forsøker å bremse vekst ved å redusere kapasiteten til deler av sine høyere utdanningssystemer for å håndtere det som anses å være overkapasitet (Bleiklie, 2017; Kvalitetsudvalget, 2015). Her må det likevel understrekes at det er betydelig variasjon på tvers av land. Oppfatningene av «metning» vil ventelig variere avhengig av hvordan formålet med høyere utdanning defineres, for eksempel som ulike typer av velferdskonsum eller investeringer i human kapital. 
I Norge og flere andre europeiske land, eksempelvis Belgia, Danmark, Finland, Sverige, Frankrike og England, har det skjedd omfattende endringer i det høyere utdanningslandskapet. Hovedgrepet fra myndighetene her er sammenslåing av institusjoner (eller tettere samarbeid i ulike konstellasjoner kalt «allianser», «føderasjoner» e.l.). De sammenslåtte institusjonene omfatter gjerne flere studiesteder med til dels store geografiske avstander og med større avstand organisatorisk og geografisk mellom de fleste ansatte og ledelsen.

Det er viktig å ta med den historiske bakgrunnen for de endringene som skjer i dag. For det første skjedde det en massiv ekspansjon i antallet institusjoner innenfor høyere utdanning fra slutten av 1960-tallet med utbyggingen av de regionale og senere statlige høgskolene. Det første skrittet var vedtaket om etablering av 15 distriktshøgskoler i 1969, som ble gjennomført i løpet av 1970-tallet. Deretter fulgte Høgskolereformen i 1994, som omfattet 98 regionale høgskoler (distriktshøgskoler, pedagogiske høgskoler, ingeniørhøgskoler, sosialhøgskoler, helsefaghøgskoler, militære høgskoler) som ble integrert i det statlige høyere utdanningssystemet i form av 26 statlige høgskoler. Selv om dette formelt sett økte antallet statlige høyere utdanningsinstitusjoner fra 11 til 38, var Høgskolereformen i 1994 først og fremst en sammenslåingsreform som reduserte tallet på offentlige høyere utdanningsinstitusjoner drastisk.

Spesielt etter Kvalitetsreformen i 2003 er det utviklet omfattende standardiserte styrings- og kontrollsystemer som gjør det mulig å måle og påvirke resultatet av institusjonenes virksomhet bedre enn før. Et felles lovverk, finansierings-, akkrediterings- og evalueringssystem, felles stillingsbetegnelser og lønnssystem, enhetlig grads- og karaktersystem, samt et felles system for registrering av forskningsresultater gjorde det mulig å sammenligne institusjonenes effektivitet og kvalitet som utdannings- og forskningsinstitusjoner. Et viktig formål var å etablere prosedyrer og insentiver som bidrar til å utvikle fremragende miljøer og profilerte, synlige institusjoner. Disse systemene ble delvis ivaretatt av et mer differensiert forvaltningsapparat med flere nye enheter under Kunnskapsdepartementet. I dag omfatter det enheter som blant andre NOKUT, Utdanningsdirektoratet, Samordna Opptak, SIU og Forskningsrådet. Et viktig formål var å utvikle administrativ kapasitet 
som gjorde det mulig å overvåke, kontrollere og følge opp institusjonenes effektivitet og kvalitet.

Det statlige høyere utdanningssystemet omfattet etter Høgskolereformen i 1994 (jf. s. 58) svært ulike utdanningstradisjoner, der universitetene representerte klassiske forskningsorienterte idealer, og de regionale høgskolene representerte kortere yrkesorienterte profesjonsutdanninger. Dette etablerte en spenning innad i systemet, der det over tid skjedde en standardisering ovenfra som tilsa økt akademisering. Viktige elementer i standardiseringen var etableringen av felles gradssystem, kompetansekriterier, evaluerings- og akkrediteringskriterier og ikke minst finansieringssystemet som ble innført med Kvalitetsreformen fra 2003. Strukturreformen har ført til en enda sterkere omforming av det norske høyere utdanningslandskapet med ytterligere sammenslåinger som har redusert tallet på statlige høgskoler fra 26 til $5 \mathrm{og} ø \mathrm{kt}$ antallet universiteter fra 4 til 10 (6 siden 2005, hvorav 3 de siste 3 årene). Den innebærer også at spenninger mellom ulike utdannings- og forskningstradisjoner i stor grad flyttes inn i de nye sammenslåtte institusjonene.

Hvis vi ser bort fra de fire eldste universitetene og de fem spesialiserte vitenskapelige høgskolene, har de fleste nye universiteter og statlige høgskoler sine tyngste utdanningstilbud på fem felt: lærer-, helsefag-, sosialarbeider-, ingeniør- og økonomisk-administrativ utdanning.

På tre av disse feltene (lærer-, helsefag- og sosialarbeiderutdanning) er behov og etterspørsel relativt forutsigbare fordi en vesentlig del av fremtidige behov for offentlige tjenester som kandidater på disse feltene skal møte, er avhengig av demografiske forhold. Selv om endringer i flyttemønstre, offentlig politikk og næringsvirksomhet kan påvirke lokal etterspørsel og tilbud, er den relative stabiliteten høy. Det er derfor grunn til å vente at de store offentlige utdanningsinstitusjonene vil kunne møte behovene og de relativt gradvise endringene i etterspørselen på disse feltene. Til dels vil dette også kunne gjelde de to andre utdanningene siden de hovedsakelig utdanner studenter til arbeid i kommunal og fylkeskommunal administrasjon og tjenesteyting. I den grad tilbudene er rettet mot privat næringsliv, for eksempel private teknologibedrifter, kan stabiliteten være lavere og gjøre tilpasning vanskeligere. Gitt dette utgangspunktet, er det grunn til å spørre hvordan strukturreformen kan bidra til å 
sette institusjonene bedre i stand til å møte lokale og regionale behov i arbeidsmarkedet.

Til sammen representerer disse tendensene tre paradokser som, om de ikke representerer uløselige konflikter, stiller institusjoner og myndigheter overfor utfordringer som kan bli vanskelige å håndtere:

Det første er forholdet mellom arbeidsmarkedsrelevans, regional utvikling og sikring av regionale utdanningsbehov, der lokal tilpasning av fagmiljøer står sentralt, og etableringen av større og mer byråkratiske, fusjonerte enheter med en ledelse som befinner seg relativ langt fra de ulike fagmiljøene. Det er grunn til å stille spørsmål om hvordan institusjonene kan tenkes å håndtere spenningen mellom disse elementene i politikken, og om denne strukturpolitikken er best egnet til å imøtekomme lokale og regionale behov.

Det andre paradokset er den åpenbare motsetningen mellom å utvikle fremragende institusjoner med klare profiler og sammenslåingen av ulike typer av institusjoner til støre, amorfe institusjoner der eventuelle fremragende miljøer inkorporeres i større enheter med sammensatte profiler og ambisjoner.

Det tredje paradokset, som i noen grad henger sammen med det andre, er akademiseringen, som standardiseringen av gradssystem, finansieringssystem, stillingskategorier, samt akkrediterings- og evalueringsprosedyrene har lagt til rette for, sett opp mot ønsket om yrkesorientering og relevans i studietilbudet. Et tydelig uttrykk for akademiseringen er økningen i tallet på universiteter sammenlignet med tallet på statlige høgskoler.

Et viktig, men lite kommunisert aspekt, er at denne typen spenninger som til nå først og fremst har blitt håndtert på sentralt politisk nivå, i større grad er blitt institusjonenes ansvar og må håndteres internt.

\section{Reformbølger og fremveksten av det høyere utdanningssystemet}

Skal vi forstå hvordan vi har endt opp med et høyere utdanningssystem som er preget av disse spenningene, kan det være nyttig å se nærmere på to sider ved den offentlige reformpolitikken slik den har utviklet seg 
siden ekspansjonen i høyere utdanning tok til for alvor etter 1960. Det ene trekket er at reformbølger med skiftende formål, til dels parallelt med lignende reformer i andre europeiske land, har avløst hverandre (Bleiklie et al., 2000, s. 1) Ekspansjonspolitikk fra 1960 til ca. 1970, 2) yrkesretting og lavere gradsutdanning fra ca. 1980 til 1990, 3) kvalitet med vekt på forskning og organisatorisk integrasjon fra ca. 1990 til ca. 2000, 4) kvalitet, standardisering og styring fra 2003 til 2013 og 5) strukturpolitikk og vekt på undervisningskvalitet, relevans for næringsliv og arbeidsmarkedet. Det andre trekket er New Public Management-inspirerte reformer som med økende styrke har preget høyere utdanning fra ca. 1990 og frem til i dag.

\section{Ekspansjonspolitikk 1960-75}

I 1960 hadde Norge 6 høyere utdanningsinstitusjoner på universitetsnivå (universiteter og vitenskapelige høgskoler) med til sammen ca. 8300 studenter, noe som var en beskjeden økning siden 1945. I 1970 hadde studenttallet blitt mer enn tredoblet til noe over 30 ooo studenter fordelt på 10 institusjoner. I årene som fulgte, vokste studenttallene raskt. Den første reformbølgen, preget av ekspansjonspolitikk, var innrettet mot å øke de eksisterende institusjonenes kapasitet til å ta imot den økende etterspørselen etter høyere utdanning. Den store økningen fant først og fremst sted innenfor de åpne eller «frie» studier i humaniora, inkludert dagens samfunnsvitenskapelige disipliner og i naturvitenskapelige fag. Dette utbyggingsmønsteret, der studenttallene økte mest der utgiftene per studieplass var lavest, har preget utbyggingen av det høyere utdanningssystemet frem til i dag.

\section{Yrkesretting og regionalisering 1975-1990}

Reformbølgen med vekt på yrkesretting og laveregradsstudier skjedde først og fremst gjennom utbyggingen av de nye distriktshøgskolene fra 1969 og utover på 1970-tallet. Formålet med utbyggingen var dels å fylle et behov for kortere yrkesrettet og rimeligere høyere utdanning, lette presset på universitetene og tilby «distriktsrelevant utdanning» (Jerdal, 1996) 
som kunne møte eksisterende lokale behov for kvalifisert arbeidskraft. I praksis førte dette til at distriktshøgskolene bygde ut 2- og 3-årige utdanninger, blant annet i økonomisk-administrative fag. I tillegg tok universitetene opp konkurransen om studentene ved å satse mer på kortere yrkesrettete laveregradsstudier. Reformperioden innvarslet begynnelsen på utviklingen av et binært høyere utdanningssystem med en spenning mellom to verdisett som på ulike måter har preget norsk høyere utdanning frem til i dag, mellom akademiske kvalifikasjoner og status på den ene siden og yrkesrettet relevans på den andre.

\section{Kvalitetspolitikk og høyeregradsstudier 1990-2000}

Rundt 1990 begynte en tredje reformbølge, som igjen innebar en omlegging av politikken. Nå var det faglig kvalitet som sto i fokus med satsing på forskning og høyeregradsstudier. Samtidig skulle integrasjonen mellom institusjonene styrkes gjennom tettere samarbeid i en nettverksstruktur som ble døpt «Norgesnettet». I denne perioden arbeidet myndighetene for å beholde den eksisterende binære strukturen med statlige høgskoler og institusjoner på universitetsnivå (universiteter og statlige høgskoler). Forsøk fra enkelte statlige høgskoler på å oppnå universitetsstatus ble derfor avvist, og gjennom Høgskolereformen i 1994 ble de regionale institusjonene forsøkt integrert innenfor en klarere formell ramme. Dreiningen av politikken i denne perioden bygde på en annen forestilling om forholdet mellom arbeidsmarked og utdanning. Tanken var at utdanning ikke bare skal møte eksisterende etterspørsel, men bidra til å utvikle økonomien og arbeidsmarkedet. I ytterste konsekvens betyr det at jo høyere utdanningsnivå arbeidskraften har, jo bedre er det for økonomisk utvikling og konkurransekraft. Den påviste statistiske sammenhengen mellom utdanningsnivået i et land og økonomisk utviklingsnivå dannet et viktig grunnlag for denne tankegangen (Meyer \& Ramirez, 200o). Tenkningen om faglig kvalitet, høyeregradsutdanning og forskning la føringer på integrasjonsprosessen og ga styrke til akademisering eller akademisk drift som en vesentlig drivkraft bak integrasjonen. 


\section{Kvalitetspolitikk og styring 2000-2010}

Kvalitet sto også i fokus i den neste perioden, som ble innledet med Kvalitetsreformen i 2003: Med innføring av et felles gradssystem, finansieringssystem, kvalitetssikringssystem, system for institusjonsstyring og utbygging av sentrale styringsorganer som NOKUT, sørget reformen for å bringe sammen en faglig reform, med styrings- og administrative reformer innenfor en felles overordnet tankegang, på en klarere og mer kraftfull måte enn tidligere. Kvalitetsreformen la stor vekt på undervisningskvalitet, men etter at ekstramidlene som ble bevilget for å heve undervisningskvaliteten, tok slutt etter tre år, var det fokuset på forskningskvalitet som kom til å prege perioden fordi finansieringssystemet som ble innført, i praksis favoriserte forskningsuniversitetene. Samtidig ble den bastante motstanden mot å svekke det binære systemet lagt til side, og det ble etablert et sett med kriterier som måtte oppfylles om en institusjon skulle oppnå universitetsstatus. Ansvaret for å avgjøre søknader fra statlige høgskoler om å bli universitet ble lagt til NOKUT. Derfor økte også andelen høgskoler med ambisjoner om å oppnå universitetsstatus. Tre strategier ble fulgt: å etablere nok master- og doktorgradsstudier til å tilfredsstille NOKUTs krav, slå seg sammen med en annen høgskole for å dele på byrdene ved en slik satsing, eller slå seg sammen med et allerede etablert universitet. I årene 2005-2007 fikk tre institusjoner, to av dem statlige høgskoler, universitetsstatus. I denne perioden ble akademisering ikke bare stimulert, men til dels lagt til grunn for de standardiserte styringssystemene, stillingssystemet og gradssystemet, som alle ble utformet på en måte som ikke bare favoriserte de tradisjonelle forskningsuniversitetene, men også stimulerte de andre institusjonene til å strekke seg etter de samme privilegiene.

\section{Konsentrasjon og relevans fra 2010 av}

Den siste reformperioden står vi i praksis midt oppi, selv om den såkalte strukturreformen formelt ble gjennomført i kjølvannet av regjeringens stortingsmelding Konsentrasjon for kvalitet (Meld. St. 18 (20142015)). Reformen har ført til etableringen av fem nye institusjoner - tre universiteter og to statlige høgskoler - som nå står oppe i omfattende 
iverksettingsprosesser. Det står institusjonene fritt hvordan de vil gjennomføre prosessen, og hvilke faglige og organisatoriske mål de ønsker å oppå. De fleste statlige høyere utdanningsinstitusjoner er nå større institusjoner med flere læresteder spredt over til dels store geografiske områder.

Hvis vi ser på målsettingene for reformen, er de, i likhet med tilsvarende reformer i andre europeiske land, mange og omfattende (Pruvot et al., 2017). Regjeringen fremhever seks mål: kvalitet, robusthet, tilgang til utdanning og kompetanse over hele landet, regional utvikling, verdensledende forskningsmiljøer, effektiv ressursbruk. Bortsett fra den generelle forutsetningen om at institusjoner og fagmiljøer må være av en viss uspesifisert størrelse, sies det lite om hvordan målsettingene kan nås, og hvordan de står i forhold til hverandre. Det som er tydelig i et reformhistorisk perspektiv, er at formålene som høyere utdanning skal tjene, er blitt flere (utdanning, forskning og flere former for formidling og samfunnsnytte), mer ambisiøse (verdensledende) og mer mangfoldige (med flere fagmiljøer, studentgrupper, næringslivsaktører og offentlige aktører med varierte krav og forventninger).

\section{Modeller for organisering og styring av universiteter}

En fellesnevner for de politiske kravene og forventningene som høyere utdanningsreformer har stilt universitetene overfor siden 1980-tallet, er et sett med underliggende forestillinger om hvordan institusjonene bør styres og organiseres. Disse forestillingene er forankret i New Public Management (NPM)-tenkning (Neave, 2002; Pollitt \& Bouckaert, 2011). Det er altså ikke bare endrete omgivelser, vekst og spesifikke utdannings- og forskningspolitiske mål som har drevet frem reformene, men i økende grad det som var nye forestillinger om hvordan universiteter og høgskoler bør organiseres og styres. Slike forslag ble stadig viktigere elementer i reformpolitikken, fra en forsiktig begynnelse i siste halvdel av 1980-tallet, til de omfattende endringene som preget reformpolitikken på 200o-tallet.

Disse reformene innebar at den tradisjonelle måten å begrunne universitetenes organisasjons- og beslutningsstruktur på, har blitt avløst av 
et helt nytt sett av ideer. Tradisjonelt har universitetet først og fremst blitt forstått som et akademisk fellesskap. Den nye tankegangen, derimot, innebar at universitetet blir sett på som bedrift (Bleiklie et al., 200o; Brunsson \& Sahlin, 2000; Musselin, 2007; Olsen, 2005). Ifølge idealet om universitetet som «akademisk fellesskap» er institusjonell autonomi og akademisk frihet to sider av same sak, siden ledelse og viktige beslutninger er i hendene på kollegiale organer befolket av uavhengige vitenskapelig ansatte. Beslutningsmakt er knyttet til ideen om universitetet som en organisasjon bestående av en rekke disiplinære fellesskap, med preferanser som er styrt av sterke normer om vitenskapelig atferd og vitenskapelig arbeid. Det «akademiske fellesskap» styres følgelig nedenfra, i samsvar med felles vitenskapelige normer som deles av de ulike faglige fellesskapene. Idealet kan spores tilbake til Middelalderuniversitetet, og har vært dominerende i ulike moderniserte versjoner frem til rundt 1980. De siste tiårene er utvilsomt preget av en bevegelse bort fra dette idealet og over mot bedriftsidealet, som har vært kommentert av en rekke forfattere (Amaral et al., 2003; Becher \& Kogan, 1992; Clark, 1998; Gornitzka et al., 2005; Neave, 2002; Olsen, 2005; Seeber et al., 2015; Slaughter \& Leslie, 1997).

Idealet om universitetet som «bedrift» innebærer at institusjonell autonomi skal gi institusjonens ledelse et grunnlag for å treffe strategiske beslutninger med sikte på å tilfredsstille interessene til de viktigste berørte partene av bedriftens virksomhet. Individuell akademisk frihet er derfor inngjerdet av de antatte behovene og interessene til strategisk viktige berørte parter. Beslutningene fattes innenfor hierarkiske strukturer som er utformet med tanke på å utstyre lederne med autoritet og administrative ressurser, slik at de kan iverksette strategisk viktige beslutninger i organisasjonen. Beslutningsmakt er samlet hos ledelsen, som styrer de ansatte som enkeltpersoner ved å påvirke atferden deres gjennom ulike insentiver. Dette skjer ikke bare ved at ledere gis mer myndighet. Beslutningsmakten styrkes dessuten ofte ved at de faglige fellesskapene i stor grad mister sitt organisatoriske grunnlag for å påvirke interne beslutningsprosesser gjennom avvikling av disiplininstitutter og andre grunnenheter basert på faglige fellesskap. Når makten samles hos ledelsen og strategisk viktige interessenter, vil den enkelte vitenskapelig ansattes 
makt dermed være mer avhengig av hvilke bytteforhold hun eller han har med ledelsen. Forskere som kontrollerer store eksterne midler, har høy prestisje. Det samme gjelder forskere som (i tillegg) sitter i strategiske posisjoner på eksterne beslutningsarenaer av betydning for institusjonen, og/eller har tilegnet seg ressurser som kan konverteres i intern innflytelse og høy grad av autonomi i forhold til interne ledere og maktstrukturer (Bleiklie et al., 2015, 2017).

Selv om bedriftsidealet innebærer at offentlig organisasjoner, offentlige universiteter inkludert, bør bli 'komplette organisasjoner' med klare mål og administrativ kapasitet til å opptre som strategiske aktører (Brunsson \& Sahlin-Andersson, 200o), er det flere som har pekt på at dette idealet neppe kan realiseres fullt ut (Musselin, 2007; Olsen, 2005; Weick, 1976). De legger vekt på at universiteter, i kraft av sine egenartete oppgaver, er 'spesifikke' organisasjoner som må operere med uklare teknologier og under betingelser som krever at beslutninger treffes gjennom prosesser som beveger seg nedenfra og opp i organisasjonen. Følgelig må de organiseres på bestemte måter som setter dem i stand til å løse sine oppgaver, noe som tilsier at det akademiske fellesskapet fortsatt har en viktig rolle å spille om institusjonene skal gjøre dette på en faglig forsvarlig måte. De to idealene og spenningen mellom dem har begge satt sine spor både i innholdet til og implikasjonene av høyere utdanningsreformer. Dette tilsier at NPM-reformer i høyere utdanning har sin klare egenart.

\section{Fem styringsrevolusjoner og noen organisatoriske implikasjoner}

Den måten NPM-inspirerte ideer har manifestert seg på i de høyere utdanningsreformene, har i økende grad virket både på systemnivå, organisasjonsnivå og på de enkelte ansattes og studentenes arbeidssituasjon. Det som var etablerte prinsipper for organisering og styring av høyere utdanning for 35 år siden, har praktisk talt blitt snudd på hodet. «Styringsrevolusjon» er derfor en treffende betegnelse, og nedenfor skal jeg peke på fem viktige revolusjoner i styring og organisering av høyere utdanning i Norge og de fleste vesteuropeiske land: 
1 Systemintegrasjon: Historisk sett har høyere utdanning bestått av en eller et begrenset antall universiteter og vitenskapelige høgskoler som til dels ble regulert direkte av de sentrale myndighetene, noen ganger gjennom spesifikke lover for den enkelte institusjon. Dagens høyere utdanningssystemer omfatter vanligvis alle institusjoner som bygger på videregående utdanning og på forskjellige måter bidrar til et felles overordnet mål under felles lovgivning, finansieringssystem og evaluerings- og akkrediteringssystemer, og som omfatter utdanninger som tidligere ble sett som yrkesorienterte og ikke-akademiske (Guri-Rosenblit et al., 2007).

2 Beslutningsprosesser: Sentrale beslutningsprosesser ved universitetene var tidligere basert på at organisasjonens beslutninger skulle gjenspeile preferansene til professorene eller den akademiske staben. I dag er tendensen at beslutninger treffes i en hierarkisk ovenfra-ned-prosess slik at de skal gjenspeile strategiene til organisasjonens toppledelse. Institusjonelle ledere opererer på en måte som ligner toppledere $\mathrm{i}$ andre store bedrifter, arbeider tett med interessenter i omgivelsene og treffer beslutninger med store konsekvenser for universitetene som organisasjoner (Amaral et al., 2003).

3 Finansiering: Mens offentlige universiteter tradisjonelt har fått dekket sine utgifter gjennom direkte bevilgninger fra staten, gjerne basert på innsatsfaktorer som antall fast ansatte i faglige stillinger og/eller antall studenter, er bevilgningene nå kjennetegnet av: a) mindre detaljert regelstyring av budsjettene fra statens side, b) at budsjettene i økende grad er basert på resultatindikatorer (f.eks. antall avlagte eksamener og/eller akademiske grader, antall og utbredelse av forskningspublikasjoner) snarere enn innsatsfaktorer (Lepori et al., 2007). Dessuten er ekstern finansiering blitt viktig, spesielt for de mest forskningsintensive universitetene.

4 Kvalitetssikring og evaluering: Tradisjonell evaluering og kvalitetssikring dreide seg vanligvis om vurderinger av enkeltpersoners akademiske prestasjoner knyttet til eksamensprosedyrer og ansettelsesprosesser. Disse evalueringsformene har nå blitt supplert med organisasjonsmessig evaluering og kvalitetssikring gjennom akkreditering, evalueringer og andre prosedyrer som kjennetegnes ved: 
a) etablering av nasjonale akkrediterings- og/eller evalueringsorganer; b) en sterk faglig-akademisk innflytelse når det gjelder å utvikle legitime evalueringskriterier og prosedyrer (Reale \& Seeber, 2013); c) en dobbel maktoverføring fra enkeltinstitusjoner og lokale faglig ansatte til nasjonale eller overnasjonale organer og akademiske elitegrupper i forbindelse med akkreditering og kvalitetssikring.

5 Arbeidsorganisering: Mens akademisk arbeid tidligere ble utført individuelt, blir det nå i økende grad utført av grupper. Denne utviklingen har blitt presset frem av: a) fremveksten av former/mekanismer for forskningsfinansiering som stiller krav om at forskerne skal arbeide i tverrfaglige, tverrinstitusjonelle og/eller internasjonale grupper; b) sammenslåinger av mindre disiplinærinstitutter i større enheter; og c) formalisering av organiserte tematiske forskergrupper som omfatter faglig ansatte i seniorstilinger, rekrutteringsstillinger og studenter på høyere nivå (Mohrman et al., 2007).

Gjennom disse fem prosessene har universitetene endret seg langs flere dimensjoner. Den ene er en bevegelse mot sterkere administrative apparater med bedre kapasitet til strategisk styring. Den andre går i retning av sterkere og mer komplekse former for avhengighet av omverdenen i forbindelse med vitale funksjoner som politisk regulering, finansiering, evaluering og styring. Den tredje er økende standardisering, nasjonalt og internasjonalt, som kan bidra til å redusere handlingsrommet til den enkelte institusjon og legge klare begrensninger på den institusjonelle autonomien i praksis.

I et organisasjonsteoretisk perspektiv har måten universitetene styres på, og de faglig ansattes innflytelse internt, beveget seg bort fra desentraliserte «organiserte anarkier» der innflytelse var forankret i ulike disiplinære fellesskap (Cohen et al., 1972), i retning av 'penetrerte hierarkier' der en mer sentralisert organisasjon, med sterkere ledelse og større administrativ kapasitet, samtidig er innvevd i en rekke gjensidige, finansielle og faglige avhengighetsforhold internasjonalt og nasjonalt (Bleiklie et al., 2015, 2017). Styrkingen av ledelsen og de administrative strukturene ved hver enkelt institusjon betyr ikke at faglig ansatte ganske enkelt har blitt skjøvet ut av maktposisjonene og satt under administrasjon. 
Derimot har den faglige, akademisk innflytelsen endret karakter på to måter. Mens den tidligere var basert på akademiske posisjoner innenfor institutter eller grunnenheter ved de enkelte institusjonene, er den nå i økende grad basert på posisjoner knyttet til organer innen forskningsfinansiering (f.eks. NFRs programstyrer), kvalitetsvurdering (evalueringsutvalg), redaksjonsutvalg, faglige vurderingskomiteer, offentlige utvalg og eksterne institusjonsstyrer. Akademisk makt er dermed i økende grad basert på posisjoner i tverrinstitusjonelle og i noen grad internasjonale nettverk heller enn akademiske posisjoner innenfor det enkelte universitet. Mens universitetene som «organiserte anarkier» var preget av desentraliserte beslutninger og svak ledelse med liten styringskapasitet, er styringskapasiteten i dagens 'penetrerte hierarkier' også begrenset, til tross for sterkere ledelse og administrative strukturer. Begrensningene ligger først og fremst i forsterket avhengighet av omgivelsene, finansielt (ekstern finansiering), faglig (ansettelser og forfremmelser) og strategisk (evalueringer). Mens rasjonaliteten i det akademiske fellesskapsidealet er knyttet til institusjonaliserte verdier der institusjonell autonomi og akademisk frihet sto sentralt, er rasjonaliteten i bedriftsidealet knyttet til forventninger om strategisk styring i transaksjonsforhold til den enkelte ansatte og til omgivelsene. Ledelse har med andre ord beveget seg bort fra en verdibasert, kollegial modell der ledere representerer fellesskapet av sine like, til et interessebasert transaksjonsforhold der ledere utveksler ressurser med sine ansatte. Sistnevnte kan, ved å bidra med ressurser til organisasjonen i form av penger, akademisk prestisje eller viktige eksterne posisjoner, konvertere disse i intern innflytelse og personlig autonomi.

Så langt kan vi konstatere at komparative studier tyder på at NPMreformer har hatt et globalt gjennomslag på fire områder: 1) ideologien tjener som begrunnelse for reformer med fokus på mer effektive institusjoner og undervisning og forskning av bedre kvalitet; 2) fremveksten av formelle organisatoriske strukturer for institusjonell evaluering og konkurranseutsatt forskningsfinansiering; 3) formalisering av prosedyrer og oppbygging av sentraladministrative apparater for å oppnå en rekke effektivitets- og kvalitetsmål; 4) økt formell institusjonell autonomi, kombinert med svekking av forbindelsen mellom institusjonell og individuell autonomi. Inndelingen i organisatoriske grunnenheter er ikke i samme 
grad basis for fagmiljøer, men preges snarere av større produksjonsenheter for større konglomerater av fagmiljøer.

Likevel er det slik at det varierer i hvor stor grad de fem «styringsrevolusjonene» i praksis har blitt gjennomført og påvirket forholdet mellom sentrale myndigheter og den enkelte institusjon, og deretter forholdet mellom akademiske institusjoner og den enkelte faglig ansatte (Paradeise et al., 2009). Mye tyder på at internasjonalt sterke forskningsuniversiteter har hatt en unik evne til å bevare styringsformer som sikrer sterk faglig innflytelse (Paradeise \& Thoenig, 2013). Likevel er hovedforklaringen på variasjonene knyttet til nasjonal tilhørighet, og dette forklarer forskjeller i styring og organisering av universiteter bedre enn forskjeller mellom institusjonstyper - for eksempel mellom tradisjonelle og «nye» universiteter og mellom allmenne forskningsuniversiteter og spesialiserte universiteter (Seeber et al., 2014). Samtidig er integrasjonen av høyere utdanningssystemer et felles trekk ved europeisk høyere utdanning, som kan bidra til å opprettholde og tydeliggjøre nasjonale forskjeller, der nasjonale regjeringer aktivt arbeider for å standardisere utdanningstilbud og organisasjonsformer med utgangspunkt i nasjonale tradisjoner (Bleiklie \& Michelsen, 2013; Paradeise et al., 2009). Her ser vi at egenskaper ved nasjonale politisk-administrative regimer legger visse rammer for hvordan utdanningsinstitusjoner og -systemer styres, samtidig som høyere utdanning som politisk sektor også er preget av særegne tradisjoner som legger sine spesifikke føringer på hvordan sektoren er styrt og organisert (Bleiklie et al., 2017). Et forhold som potensielt kan redusere slike særegenheter i sektoren, er utviklingen av et europeisk akademisk arbeidsmarked, slik det har vokst frem de siste 10 til 15 årene.

\section{Avslutning}

Norske universiteter har gjennomgått grunnleggende endringer som organisasjoner. De ulike reformbølgene viser hvordan universiteter og høgskoler har blitt pålagt stadig nye oppgaver. De er gjenstand for sterkere press for å åpne seg mot omgivelsene, lokalt, nasjonalt og internasjonalt, og ta inn over seg nye krav og forventninger fra samfunnet. Samtidig har systemet og de enkelte institusjonene gjennomgått omfattende endringer 
i styrings- og organisasjonsformer. Dette setter myndighetene bedre i stand til å øke presset mot institusjoner og ansatte til å ivareta stadig flere oppgaver og hensyn. I tråd med dette utvikles det ikke bare måter å måle den enkeltes og institusjonenes arbeidsinnsats og produktivitet på når det gjelder forskning og undervisning, men også når det gjelder formidling og andre former for samfunnsrelevante aktiviteter. De tre paradoksene jeg pekte på innledningsvis, betyr at alle oppgavene ikke kan løses like godt til enhver tid. Reformbølger med sine særegne prioriteringer for eksempel når det gjelder vekt på korte, yrkesrettete versus lange forskningsorienterte utdanninger - er et uttrykk for dette. Dette viser også at systemene ikke er stabile, og at skiftende politiske prioriteringer like gjerne skyldes endrete ideologisk betonte forestillinger om hva som bør prioriteres, som klart formulerte sosiale og økonomiske behov (Meyer \& Ramirez, 2000). Siden universiteter i dag finnes i alle deler av landet, dreier en del av forventningspresset seg om å møte regionale og lokale behov innenfor utdanning og forskning. Vi vet mindre om variasjoner i lokal tilpasning, selv om «regionale» universiteter gjerne forutsettes å utvikle tydelige lokale bånd som preger innrettingen av utdannings- og forskningstilbud. I lys av dette presset har jeg stilt spørsmål ved om institusjonene vil være i stand til å møte forventningene. Spesielt har jeg stilt spørsmål ved om kombinasjonen av økende standardisering, akademisering og internasjonalisering innenfor stadig større flercampusinstitusjoner er egnet til å møte behov for lokal og regional tilpasning. Spenningene i politikken tilsier at utviklingen innenfor den enkelte institusjon kan gå i flere retninger. Selv om det er grunn til å anta at trykket fra standardiserings- og akademiseringsprosessene er tunge (Kyvik, 2019), så møter de trolig varierende grader av oppslutning og motstand i fagmiljøene (Michelsen \& Halvorsen, 2002). Det er mye som tyder på at noen fagmiljøer er i god posisjon til å yte motstand, bremse akademiseringsprosessen og beholde tette bånd til lokale bedrifter og en sterk yrkesorientering i studietilbudet. Derfor er det av stor interesse å undersøke nærmere hvordan forholdet mellom lokale bedrifter og regionale universiteter er organisert på institusjonsnivå, men også relasjonene mellom de enkelte fagmiljøene og de delene av næringslivet og den offentlige forvaltningen de betjener. Hvordan institusjonene håndterer balansen mellom akademisering 
og standardisering på ene siden og lokal tilknytning og yrkesretting på ulike fagfelt på den andre siden, er én viktig problemstilling, en annen er hvordan denne balansen påvirkes av de pågående fusjonsprosessene. Begge deler er spørsmål det er av stor interesse å klarlegge bedre enn det er gjort til i dag.

\section{Referanser}

Amaral, A., Meek, L. \& Larsen, I. M. (Red.) (2003). The higher education managerial revolution? Dordrecht: Kluwer Academic Publishers.

Becher, T. \& Kogan, M. (1992). Process and structure in higher education. Milton Keynes: Open University Press.

Ben-David, J. \& Zloczower, A. (1991). Universities and academic systems in modern societies. I J. Ben-David, Scientific Growth. Berkley, Los Angeles, London: University of California Press.

Bleiklie, I. (2017). Some assumption about the relationship between higher education, the labor market, vocational education and the political system. Paper presentert på Scancor Spring Seminar, Organizations, Institutions, and Nation-States, Weatherhead Center for International Affairs, Harvard University, Cambridge, 11. -12. mai 2017.

Bleiklie, I. \& Byrkjeflot, H. (2002). Changing knowledge regimes - universities in a new research environment. Higher Education, 44(2-3), 519-532.

Bleiklie, I., Enders, J. \& Lepori, B. (2015). Organizations as penetrated hierarchies: Environmental pressures and control in professional organizations. Organization Studies, 36(7), 873-896.

Bleiklie, I., Enders, J. \& Lepori, B. (Red.) (2017). Managing universities: Policy and organizational change in a Western European comparative perspective. Basingstoke: Palgrave MacMillan.

Bleiklie, I., Høstaker, R. \& Vabø, A. (200o). Policy and practice in higher education. Reforming Norwegian universities. London and Philadelphia: Jessica Kingsley.

Brunsson, N. \& Sahlin-Andersson, K. (2000). Constructing organizations: The example of the public sector reform. Organization Studies, 21(4), 721-746.

Clark, B. R. (1998). Creating entrepreneurial universities: Organizational pathways to transformation. Oxford, New York, Tokyo: IAU Press/Pergamon.

Cohen, M. D., March, J. G. \& Olsen, J. P. (1972). A garbage can model of organizational choice. Adminstrative Science Quarterly, 17, 1-25.

Gornitzka, A., Kogan, M. \& Amaral, A. (red.) (2005). Reform and change in higher education: Analyzing policy implementation (s. 97-116). Dordrecht: Springer. 
Guri-Rosenblit, S., Sebkova, H. \& Teichler, U. (2007). Massification and diversity of higher education systems: Interplay of complex dimension. Higher Education Policy, 20, 373-389.

Jerdal, E. (1996). Distriktshøskolen - alternative utdanning? I I. Bleiklie (Red.), Kunnskap og makt. Norsk høyere utdanning i endring. Oslo: Tano-Aschehoug.

Kvalitetsudvalget (2015). Nye veje og høje mål. Kvalitetsudvalgets samlede analyserapport. København: Utvalg for kvalitet og relevans i de Videregående Uddannelser.

Kyvik, S. (2009). The dynamics of change in higher education. Expansion and contraction in an organizational field. Dordrecht: Springer.

Lepori, B. et al. (2007). Comparing the evolution of national research policies: What patterns of change? Science and Public Policy, 34(6), 372-388.

Mintzberg, H. (1979). The structuring of organizations. Englewood Cliffs, NJ: Prentice-Hall.

Musselin, C. (2007). Are universities specific organisations? I G. Krücken, A. Kosmützky \& M. Torka (Red.), Towards a multiversity? Universities between global trends and national traditions (s. 63-84). Bielefeld: Transcript.

Meyer J. \& Ramírez, F. (200o). The world institutionalization of education. I J. Schriver (Red.), Discourse formation in comparative education (s. 111-132). New York: Peter Lang Publishers.

Michelsen, S. \& Halvorsen, T. (red.) (2002). Faglige forbindelser. Profesjonsutdanning og kunnskapspolitikk etter Høgskolereformen. Bergen: Fagbokforlaget.

Mohrman, K., Baker, D. \& Ma, W. (2007). The research university in transition: The emerging global model, Higher Education Policy, 21(1), 5-27.

Neave, G. (2002). The stakeholder perspective historically explored. I J. Enders \& O. Fulton (Red.), Higher education in a globalizing world. International trends and mutual observations. Dordrecht: Kluwer.

NOU 2015: 1 (2015). Produktivitet - grunnlag for vekst og velferd.

Produktivitetskommisjonens første rapport (s. 338-361). Utredning fra et utvalg oppnevnt av regjeringen Solberg 7. februar 2014. Avgitt til Finansdepartementet 10. februar 2015. Oslo: Departementenes sikkerhets- og serviceorganisasjon Informasjonsforvaltning.

Nowotny, H., Scott, P. \& Gibbons, M. (2001). Re-thinking science. Knowledge and the public in an age of uncertainty. Cambridge: Polity.

Olsen, J. P. (2005). The institutional dynamics of the (European) university. ARENA Working Paper Nr. 15, Center for European Studies, University of Oslo, mars 2005. Oslo: Universitetet i Oslo.

Paradeise, C., \& Thoenig, J. (2013). Academic institutions in search of quality: Local orders and global standards. Organization Studies, 34(2), 189-218.

Paradeise, C., Reale, E., Bleiklie, I., \& Ferlie, E. (Red.) (2009). University governance. Western European comparative perspectives. Dordrecht: Springer. 
Pollitt, C., \& Bouckaert, G. (2011). Public management reform: A comparative analysis: New public management, governance, and the neo-weberian state (3. utg.). Oxford: Oxford University Press.

Scott, W. R. \& Kirst, M. W. (2017). Higher education and Silicon Valley. Baltimore: Johns Hopkins University Press.

Seeber, M. et al. (2014). European universities as complete organizations?

Understanding identity, hierarchy and rationality in public organizations. Public Management Review, 17(10), 1444-1474.

Slaughter, S. \& Leslie, L. (1997). Academic capitalism. Baltimore: Johns Hopkins University Press.

Weick, K. E. (1976). Educational organizations as loosely coupled systems. Administrative Science Quarterly, 21, 1-19. 


\title{
KAPITTEL 3
}

\section{Reformer i UH-sektoren. Det muliges kunst}

\author{
Nicoline Frølich \\ NIFU - Nordisk institutt for studier av Innovasjon, Forskning \\ og Utdanning
}

Jarle Trondal

Institutt for statsvitenskap og ledelsesfag, Universitetet i Agder

\section{Joakim Caspersen}

NTNU Samfunnsforskning

\section{Ingvild Reymert}

\author{
NIFU - Nordisk institutt for studier av Innovasjon, Forskning \\ og Utdanning
}

\begin{abstract}
Public sector reform tends to harbour competing ambitions, problems and solutions. Reforms in higher education policy are no exception. They are often multi-faceted phenomena, partly because higher education institutions are complex organizations with wide-ranging expectations and demands from a variety of stakeholders. This chapter argues that higher education institutions cannot 'organize away' competing objectives, but rather aim to create organizational designs which help complex institutions to live with complex reforms. The chapter examines the 'Structural Reform' in Norwegian higher education and how higher education institutions responded. Launched in April 2015, it resulted in a large-scale organizational redesign of the higher education landscape through merger processes between university colleges as well as between universities and university colleges. As with other reforms in higher education, the Structural Reform focused on several desirable but competing objectives such as high-quality education and research, regional development and world leading academic environments.
\end{abstract}

Keywords: higher education, public sector reform, organisational design, universities, university colleges, mergers

Sitering av dette kapitlet: Frølich, N., Trondal, J., Caspersen, J., \& Reymert, I. (2019). Reformer i UHsektoren. Det muliges kunst. I J. P. Knudsen \& T. Lauvdal (Red.), Geografi, kunnskap, vitenskap. Den regionale UH-sektorens framvekst og betydning (s. 75-98). Oslo: Cappelen Damm Akademisk. https://doi. org/10.23865/noasp.73.ch3.

Lisens: CC BY 4.0 


\section{Introduksjon}

Strukturmeldingen (Kunnskapsdepartementet, 2015), som ble lagt frem våren 2015, la grunnlaget for en stor fusjonsprosess i norsk høyere utdanning. Meldingen ble lansert med forslag om å redusere antallet institusjoner for høyere utdanning i Norge for å oppnå høy kvalitet i høyere utdanning:

Vi har nå satt i gang arbeidet med en stortingsmelding om struktur $i$ høyere utdanning. Målet med prosessen er å sikre høy kvalitet $i$ alle studietilbudene $i$ universitets- og høyskolesektoren. Vi tar sikte på at stortingsmeldingen legges fram våren 2015. Vi skal ikke starte strukturarbeidet med å tegne kartet. Først vil vi sette tydelige kvalitetskrav, så vil strukturen i høyere utdanning følge av disse standardene. Jeg tror likevel det er sannsynlig at en av konklusjonene i prosessen vil veere at vi bør redusere antallet institusjoner. Det betyr ikke nødvendigvis en reduksjon $i$ antallet loeresteder eller campuser, men kvalitetskravene må få konsekvenser for strukturen. (daværende kunnskapsminister Torbjørn Røe Isaksen, se Regjeringen, 2014a)

Dette kapitlet viser at reformens fokus på kvalitet ikke var så enkelt å gjennomføre. Det viste seg raskt at strukturreformen kom til å handle om å realisere konkurrerende målsettinger i UH-sektoren. Reformen skulle fremme regional utvikling, relevans og god tilgang på utdanning $i$ hele landet, samtidig som Norge skulle få flere verdensledende fagmiljøer og hevde seg bedre i den internasjonale konkurransen om forskningsressurser og kunnskapsutveksling. Spenninger mellom konkurrerende målsettinger er imidlertid ikke nytt i UH-sektoren, reformen aktualiserte en varig spenning mellom relevans og eksellens i sektoren.

Relevans og eksellens kan ses på som ulike kvalitetsaspekter eller ulike kvaliteter i høyere utdanning, og reformens mål var slik sett å fremme slike kvaliteter. Kvalitet $i$ høyere utdanning kan ses på som et sammensatt fenomen med minst fire betydninger: Kvalitet betegner det som er fremragende eller eksellent. Kvalitet i høyere utdanning betyr også å være relevant. Det kan bety å være effektiv og å være i henhold til en standard (Frølich, 2015; Harvey \& Green, 1993). UH-institusjonenes mandat er å oppfylle disse kvalitetsaspektene, men som målsettinger kan de komme i innbyrdes konkurranse. I dette kapitlet diskuterer vi hvordan 
UH-organisasjoner møter krav om å iverksette et sett med konkurrerende målsettinger i lys av strukturreformen.

Kapitlet viser at UH-organisasjonene møter problembeskrivelsen for sektoren om at den består av mange små og sårbare fagmiljøer, med en sammensatt argumentasjon som begrunner hvert enkelt læresteds forslag om sin nye plass i UH-strukturen i Norge. Mens reformen la til grunn en oppfatning om at økt størrelse var løsningen på kvalitetsutfordringene, bruker UH-organisasjonene ulike sett med argumenter i møte med reformen. Vi viser hvordan UH-organisasjonene møter reformen med ulike forståelser av hva kvalitet er, og hvordan reformen skal fremme dette. Interessant nok ser vi at lærestedene bruker argumentet om å øke den regionale betydningen og UHs relevans både som argument for å fusjonere og som argument for å la være. Dette står i en interessant motsetning til reformens hovedargument om fusjoner som virkemiddel for å fremme verdensledende forskning. Vi fortolker reformprosessen i lys av ulike organisasjonsteoretiske vinklinger på reformer og finner at stiavhengighet og tidstypiske rasjonaliserte myter kan se ut til å forklare utfallet så langt.

Kapitlet gir en gjennomgang av bakgrunnen for reformen knyttet til problemet med små og sårbare fagmiljøer, løsningsforslaget med sammenslåinger, internasjonale utviklingstrekk og enkelte trekk ved den norske reformen. I neste omgang presenterer vi noen teoretiske ideer som benyttes for å kaste lys over reformene. I den empiriske delen av kapitlet presenterer vi hvordan UH-organisasjonene har respondert på strukturreformen. Kapitlet avsluttes med noen betraktninger om reformens årsak og fremtid.

\section{Problemet: små og sårbare fagmiljøer}

I en tale samme dag som reformen ble varslet i januar 2014, sa ministeren:

I dag er kvalitetsforskjellene i universitets- og høyskolesektoren for store, og regjeringen vil la kvaliteten avgjøre hvor mange høyskoler og universiteter Norge skal ha i fremtiden.

For over ti år siden ble kvalitetsreformen gjennomført i høyere utdanning $i$ Norge. Reformen har ført til flere positive endringer. Blant annet har de fleste studietilbudene blitt mer relevante, og samarbeidet med studiesteder $i$ utlandet har økt. 
Samtidig har vi flere indikasjoner på at studiekvaliteten ikke har bedret seg som forventet. Derfor la regjeringen nylig frem en plan for hvordan vi skal sikre Norge de universitetene og høyskolene vi trenger for fremtiden.

En rekke fagevalueringer viser at vi har utfordringer når det gjelder kvaliteten $i$ norsk høyere utdanning. Dette understrekes av funn Nasjonalt organ for kvalitet $i$ utdanningen (NOKUT) har gjort. De viser også at grunnutdanningene, det vil si bachelorgrader og korte profesjonsutdanninger, som sykepleier- eller ingeniørutdanningene, nedprioriteres. Flere analyser, blant annet Stjernø-utvalgets NOU-rapport fra 2008, viser at vi sprer ressursene til forskning og høyere utdanning for tynt. Vi har for mange små og sårbare fagmiljø som tilbyr de samme utdanningene. Det fører til at for mange loeresteder konkurrerer med hverandre, $i$ stedet for å samarbeide. Da er faren stor for å ende opp $i$ en ond sirkel der vi motarbeider den kvaliteten vi ønsker å oppnå. Her trengs det åpenbart grep. (Regjeringen, 2014b)

I argumentasjonen for strukturreformen står diagnosen små og sårbare fagmiljøer sentralt. I meldingen argumenteres det innledningsvis som følger:

Det er mange positive utviklingstrekk $i$ den norske universitets- og høyskolesektoren. Men det er også en rekke utfordringer, sarlig knyttet til små, sårbare forskningsmiljøer og mange spredte, små utdanningstilbud med sviktende rekruttering. Den samlede internasjonale deltakelsen er også lavere enn ressursgrunnlaget tilsier.

Derfor er det nødvendig å endre strukturen i universitets- og høyskolesektoren og samle ressursene på forre, men sterkere institusjoner. Strukturreformen skal styrke kvaliteten på utdanningen og forskningen. Tilgangen til høyere utdanning skal vere god over hele landet, og institusjonenes regionale rolle skal videreutvikles. (Kunnskapsdepartementet, 2015)

Problembeskrivelsen i Stortingsmeldingen var derfor relativt klar og koblet til «små, sårbare forskningsmiljøer og mange spredte, små utdanningstilbud med sviktende rekruttering. (...) Derfor er det nødvendig å endre strukturen i universitets- og høyskolesektoren og samle ressursene på færre, men sterkere institusjoner». Meldingen definerer en rekke krav til institusjonene, med et mål om å skape sterke og stabile fagmiljøer. 
Disse kravene uttrykkes som et sett kvalitetsindikatorer som lanseres som et sett kriterier institusjonene vil bli målt på med tanke på om de kan fortsette som selvstendige enheter eller bør fusjonere med andre. Reformen er uklar i den forstand at motstridende målsettinger formuleres der hensynet til verdensledende forskning møter hensynet til regional tilgang til høyere utdanning. Likevel, medisinen som foreskrives for å nå begge målsettinger, er fusjoner.

\section{Løsningen - sammenslåinger}

Siden lanseringen av strukturreformen i 2015 har det norske UH-landskapet blitt betydelig endret på kort tid. Den raske reduksjonen av antall læresteder og omfattende sammenslåinger på kryss og tvers i sektoren kan forstås i et historisk-institusjonelt perspektiv, der strukturreformen ses som avhengig av tidligere reformprosesser i norsk UH-sektor. Strukturreform er slik sett ikke et nytt tiltak i sektoren. Tidligere oppfatninger av hva som er egnede løsninger, synes å forme fremtidige løsningsforslag. Strukturreformen har aner tilbake til kvalitetsreformen i 2003, som blant annet ga høgskolene mulighet til å søke universitetsstatus. Høgskolene selv er et gammelt resultat av høgskolereformen i 1994, og siden begynnelsen av 200o-tallet har det pågått omfattende strukturendringer i UH-landskapet, spesielt i etterkant av Stjernø-utvalgets rapport i 2008 (Stjernø-utvalget, 2008), som dannet grunnlaget for SAK-politikken (Samarbeid, Arbeidsdeling og Faglig Konsentrasjon) (Elken \& Frølich, 2016).

På denne måten drives endringene i UH-landskapet både av strukturinitiativer som fusjoner og sammenslåingsprosesser og av endringer i reguleringer som muliggjorde endringer i institusjonskategori, fra høgskole til universitet. Flere høgskoler har endret institusjonskategori i denne reformperioden (Stavanger, Agder, Ås og Nordland) og oppnådde universitetsstatus. I etterkant av strukturreformen har flere høgskoler og universitet fusjonert og blitt til «nye» institusjoner, som Universitetet i Tromsø, Norges arktiske universitet, Nord universitet og Norges teknisk-naturvitenskapelige universitet - NTNU. I tillegg har flere høgskoler slått seg sammen med et ønske om å bli sterkere og for i neste omgang å oppnå universitetsstatus. Storbyuniversitetet (OsloMet) og Universitetet 
i Sørøst-Norge har fått universitetsstatus på denne måten, mens høgskolene i Vestlandet og Innlandet har signalisert et slikt mål.

Endringene i kjølvannet av strukturreformen kan derfor ikke ses uavhengig av lange, inkrementelle utviklingstrekk og endringsprosesser i norsk UH-sektor, der flere av fusjonene har foregått gradvis og over lang tid. Som for eksempel UiT, som har gjennomført fusjoner med flere høgskoler i løpet av de 10 siste årene. UiT og Høgskolen i Tromsø fusjonerte i 2009, i 2013 fusjonerte Høgskolen i Finnmark og UiT, og i 2016 fusjonerte UiT med Høgskolen i Harstad og Høgskolen i Narvik (Tellmann, Røsdal \& Frølich, 2016).

\section{Internasjonale utviklingstrekk}

Endringene i det norske UH-landskapet har slik sett foregått over mange år. I tillegg kan strukturreformen også ses i sammenheng med internasjonale utviklingstrekk i organiseringen av offentlig sektor og høyere utdanning. De siste 30 årene har det blitt vanlig å gå bort fra tanken om universiteter og høgskoler som særegne institusjoner (Bleiklie \& Frølich, 2014; Musselin, 2007) og i større grad vurdere dem på lik linje med andre organisasjoner (Christensen, 2011; Paradeise, Reale, Bleiklie \& Ferlie, 2009). Dette utviklingstrekket bidrar til at UH-institusjonene blir forsøkt reformert i tråd med generiske idealer for styring og ledelse, og forklarer at de i dag kjennetegnes av ulike konkurrerende styrings- og ledelsesidealer.

Mange europeiske land har også gjennomført strukturendringer i høyere utdanning med mål om økt effektivitet og kvalitet de siste tiårene (Boer et al., 2017). Selv om begrunnelsene for sammenslåingsprosessene varierer, har de til felles at de i stor grad handler om å kombinere kvalitet og effektivitet (Pruvot, Estermann \& Mason, 2015). Samtidige reformer på tvers av land kan ses som uttrykk for tilpasning til internasjonale normative reformomgivelser, noe vi kommer tilbake til nedenfor.

\section{Komplekse endringsprosesser}

Som nevnt innledningsvis har høyere utdanningsinstitusjoner et bredt samfunnsmandat og skal oppnå flere og konkurrerende målsettinger 
koblet til ulike samfunnsoppgaver - i form av utdanning og forskning av høy kvalitet, men også som bidragsytere til regional utvikling og innovasjon (Castells, 2001).

Vi har også vektlagt at UH-organisasjoner som moderne kunnskapsorganisasjoner har utviklet seg i retning av å bli mer lik andre organisasjoner - og at de i mindre grad ses på som særegne institusjoner. Dette bidrar til at de lettere utsettes for krav om reformer, lik de andre organisasjoner møter. I lys av dette har UH-organisasjoner gjennomgått en rekke reformer med et fokus på å skape helhetlige organisasjoner med strategisk kapasitet (Krücken \& Meier, 2006; Seeber et al., 2015). Dette innebærer ofte økt oppmerksomhet knyttet til å strømlinjeforme organisasjonen internt og forsterke den administrative styringslinjen. Men det medfører ikke at særegne kjennetegn ved disse organisasjonene nødvendigvis forsvinner - de er fortsatt organisasjoner preget av betydelig faglig ekspertise, som tradisjonelt har gjort dem «bunntunge», og som utfordrer deres muligheter til å opptre som strategiske aktører (Whitley, 2008). Dette uttrykkes gjerne som at UH-organisasjonene kjennetegnes av ulike interne logikker, både en administrativ og en faglig logikk. Reformer i UH-sektoren henter derfor legitimitet og medvirkning fra begge logikkene. Denne sammensatte organiseringen av UH-organisasjoner fører til at statlige reformer ofte møtes med motstridende logikker og gjerne tilsynelatende inkonsistente responser. Slike dilemmaer mellom konkurrerende målsettinger og spenninger koblet til dynamikkene mellom ulike logikker, finnes igjen i de fusjonerte institusjonene og preger mulighetene de har til å realisere mål. I endringsprosesser som fusjoner vil disse spenningene kunne produsere nye utfordringer fordi organisasjonene som fusjonerer, har særegne historier, tradisjoner, og normer for hvordan spenninger har blitt håndtert tidligere.

På toppen av dette kommer en geografisk faktor: Geografi og geografiske avstander er et viktig tilleggsmoment i den norske prosessen. Flere av de nyfusjonerte institusjonene har mange campuser med spredte lokasjoner som kompliserer både den faglige og den administrative organisasjonsstrukturen. Fusjonsprosessenes geografiske element kommenteres nedenfor. 


\section{Kan og bør målkonflikter organiseres bort?}

Kolliderende interne styringslogikker reflekterer at UH-organisasjonene preges av ulike prinsipper for organisering av myndighetsstruktur (Larsen, 1999; Larsen, Maassen \& Stensaker, 2009; Maassen \& Stensaker, 2003), og de har som diskutert over en sammensatt og kompleks organisasjonsstruktur - tilsvarende hybride og turbulente organisasjoner (Greenwood, Raynard, Kodeih, Micelotta \& Lounsbury, 2011). Disse organisasjonene karakteriseres gjerne av rasjonaliseringsprosesser knyttet til styring og ledelse der bedriftsinspirerte styringsidealer har blitt mer fremtredende (Larsen, 1999), samtidig som de vektlegger medvirkning for å skape legitimitet i beslutnings- og endringsprosesser (se andre nylige organisasjonsevalueringer Elken \& Røsdal, 2015; Lekve, Elken, Røsdal \& Gleinsvik, 2014; Lekve, Kyvik et al., 2014; Røsdal, Elken, Stensaker \& Gunnes, 2015).

Det kan argumenteres for at et effektivt organisasjonsdesign for å realisere konkurrerende målsettinger handler om å finne balanse mellom konkurrerende mål (Egeberg \& Trondal, 2018). Vi argumenterer derfor for at det verken er mulig eller ønskelig å organisere seg bort fra målkonflikter, og for at organisasjonsendringer handler om å skape organisasjonsformer som kan håndtere spenninger mellom ulike logikker og styringsidealer på en måte som ikke blokkerer institusjonene (Ansell, Trondal \& Øgård, 2017). Vi legger vekt på at UH-organisasjonene skal realisere et sett med konkurrerende mål nedfelt i særegne trekk, tradisjoner, historie og identitet. Dette danner grunnlag for rivninger ved fusjonsreformer der tidligere ulike organisasjoner skal bli til en ny organisasjon. I diskusjonen av strukturreformen og de pågående endringsprosessene i norsk UH-sektor har vi også vektlagt at endringsprosessene er komplekse organisasjonsendringer som det kan være sentralt å sikre medbestemmelse og legitimitet for, for at målene i strukturreformen skal kunne iverksettes.

\section{Hvordan skal møtet mellom reformer og organisasjoner forstås?}

Møtet mellom reformer og organisasjoner kan forstås ut fra flere teoretiske perspektiver. Vi velger å se på trekk ved organisasjoner, trekk ved 
reformer, trekk ved omgivelsene, og forholdet mellom organisasjoner, deres historie og omgivelsene. Dette kapitlet legger særlig vekt på forholdet mellom trekk ved reformene og trekk ved organisasjonene for å belyse UH-organisasjonenes respons på strukturmeldingen.

\section{Trekk ved organisasjoner}

I fremstillingen over har vi vektlagt at UH-organisasjoner er kjennetegnet ved at de skal oppfylle et sammensatt mandat og utsettes for forventninger om å realisere konkurrerende målsettinger: De skal for eksempel være fremragende og relevante på samme tid. Et organisasjonsteoretisk perspektiv vil vektlegge at interne organisasjonsmessige kjennetegn ikke bare forklarer hvordan organisasjoner virker, men også hvordan de endrer seg. Trekk ved organisasjonen former beslutningsadferden og beslutningsprosesser, og gjør visse strategiske valg mer sannsynlige enn andre (Waldo, 1952). Trekkene ved organisasjonen mobiliserer oppmerksomhet og handlingskapasitet rundt visse problemer og løsninger, mens de ignorerer andre; de fokuserer oppmerksomhet på visse konflikt- og samarbeidslinjer, gir problemløsningskapasitet, og skaper muligheter for koordinering (Egeberg \& Trondal, 2018). Organisasjonsfaktorer er derfor ikke symbolske artefakter (Brunsson, 1989; Meyer \& Rowan, 1977), men strukturer som skaper systematisk skjevhet i organisasjoners handlinger. Ett forbehold må imidlertid nevnes: Disse antakelsene gjelder særlig i organisasjoner som er stabile, og der grunnleggende antakelser ikke er gjenstand for konflikt - for eksempel i nye organisasjoner eller i organisasjoner under transformasjon (Olsen, 2017). Vi forventer derfor at dette perspektivet vil ha begrenset gyldighet for UH-organisasjoner som både kjennetegnes av ulike og konkurrerende oppfatninger internt om hva som er organisasjonens formål og hensikt, og som i vårt tilfelle er under transformasjon eller i det minste satt under forventning om å gjennomføre endringer.

\section{Trekk ved reformer}

I vår gjennomgang av reformer og utviklingstrekk i UH-sektoren nasjonalt og internasjonalt la vi vekt på at strukturreformen må fortolkes i lys 
av en lang reformhistorie i norsk UH-sektor og også i lys av reformer i universitets- og høgskolesektoren internasjonalt. I et organisasjonsteoretisk perspektiv vil man anta at trekk ved hvordan reformer organiseres, påvirker selve reformprosessen på to måter: For det første kan eksisterende strukturer, demografi og lokaliseringer påvirke selve reformprosessen; for det andre kan reformprosessene være bevisst organisatorisk designet for å oppnå bestemte mål. For eksempel kan vi anta at reformprosesser vil forløpe ulikt om de er vertikalt forankret i organisasjonens ledelse for eksempel hos rektor ved et universitetet - eller om de er forankret i bunnen av organisasjonen - for eksempel i fagstabene ved universitetenes institutter. Reformer i UH-sektoren kritiseres ofte for å være forankret mer i toppen enn i bunnen av organisasjonene. Dette vil påvirke hvilke aktører og argumenter som oppfattes som legitime og effektive, og således påvirke selve reformprosessen. Dersom reformprosessene er vertikalt desentraliserte, kan vi anta at berørte parter, slik som interesseorganisasjoner og interne fagforeninger, blir mobilisert og aktiverer motstand (Egeberg \& Trondal, 2018). Reformer som også omfatter flere organisasjoner, kan antas å bli mer kompliserte enn om de bare omfatter én organisasjon. Slik kan flercampusreformer mobilisere flere aktører og argumenter og bli mer komplekse enn éncampusreformer. Endelig, siden dag-til-dag beslutningsprosesser ved universitetene nødvendigvis må pågå parallelt med reformaktiviteter, blir spørsmålet hvor mye ekstra stand-by organisatorisk kapasitet som finnes for reform (March \& Olsen, 1989). Derfor vil organisatorisk kapasitet/størrelse spille inn: Større universiteter vil lettere kunne avse ekstra oppmerksomhet rundt en reform enn små universiteter.

\section{Egenskaper ved omgivelsene}

Som nevnt over, preges reformer gjerne av samtidige reformer i andre land. Når det gjelder strukturreformer, har vi sett at mange andre land også har gjennomført likende reformer i UH-sektoren med formål å fremme kvalitet og effektivitet. Denne utviklingen kan forstås ut fra et omgivelsesperspektiv, som er en bred kategori ideer som antar at organisasjoner er åpne systemer, og at organisasjoner tilpasser seg sine nære 
omgivelser (Fligstein, 2001; Meyer \& Rowan, 1977; Pfeffer \& Salanick, 1978). Selznick (1957) argumenterte for at organisasjoner må tilpasse seg sine omgivelser for å vokse og overleve. En idé om institusjonell endring gjennom diffusjon og isomorfi forklarer endring gjennom tilpasning til institusjonaliserte omgivelser og institusjonelle felt. Institusjoner oppstår og tilpasser seg rasjonaliserte myter, ideer og normer i omgivelsene som gir mer eller mindre upresise oppskrifter på hvordan «moderne» organisasjoner bør struktureres, bemannes, lokaliseres og ledes (Meyer \& Rowan, 1977; Tolbert \& Zucker, 1983). Særlig blant nye organisasjoner og organisasjoner som befinner seg i situasjoner som er uklare og usikre, vil søke legitimitet gjennom å tilpasse seg omgivelsenes kulturelle regler og oppskrifter. Oppskrifter som assosieres med det «moderne», antas å spre seg fra en organisasjon til en annen, samt mellom land. Tilpasningspresset kommer i bølger som kortvarige moter (Abrahamson, 1991) eller som langsiktige og dype trender med globalt nedslagsfelt (Meyer, Boli, Thomas \& Ramirez, 1997). På denne måten blir en organisasjonsreform løsningsdrevet snarere enn problemdrevet (DiMaggio \& Powell, 1983). Det finnes ulike drivere for slik tilpasning, slik som stater, internasjonale organisasjoner, konsulentfirmaer og transnasjonale nettverk. Det finnes også komplekse dynamikker for spredning, der kulturelle regler filtreres og oversettes i møte med lokale organisasjoner, og der organisasjoner dermed reproduserer seg selv (Sahlin \& Wedlin, 2008). I tråd med dette har en såkalt pragmatisk litteratur presentert en mellomposisjon mellom stabilitet og endring, der organisasjoner både tilpasser seg omgivelser for å løse pågående problemer og samtidig forsvarer sentrale kjerneverdier (Ansell, Boin \& Farjoun, 2015). En empirisk forventning er likevel at organisasjoner tilpasser seg omtrent samme reformløsning innenfor samme tidsperiode, selv om lokale problemer varierer.

\section{Organisasjoner, deres historier og omgivelsene}

Strukturreformen la til grunn at norsk UH-sektor var kjennetegnet av små og sårbare fagmiljøer, og hadde som hovedformål å fusjonere for å fremme bedre kvalitet i forskning og høyere utdanning. Umiddelbart var 
det enkelt å se at formålet fremsto som å styrke verdensledende forskning i Norge. Vi har også argumentert for at formålet med fusjonene var å fremme et bredere sett av målsettinger som også konkurrerer med hverandre - verdensledende og relevant, på en gang. Empirisk undersøker vi hvordan UH-organisasjonene møtte dette forventningssettet.

Vår fortolkning ligger tett opp til dette tredje perspektivet, som legger vekten på relasjonen mellom organisasjoner, deres historie og omgivelsene. Sammenhengen kan tenkes å bli påvirket av en rekke faktorer, som allerede påpekt av Herbert Simon (1957). I den første (sårbare) fasen i en organisasjons liv vil den være på søken etter egen misjon, form, rolle og identitet. Den utvikler rutiner og kapasiteter for å håndtere hendelser og for å lære av egne erfaringer. På denne måten blir organisasjonens egen historie kodet inn i regler og rutiner. Som følge av dette kan organisasjonens struktur ikke endres gjennom rasjonelt design. Reformer vil snarere bidra til inkrementell endring gjennom lokal tilpasning og læring fra historie og organisasjonens nære handlingsomgivelser. Reformer oppstår derfor ikke bare som følge av omgivelsespress, som et svar på funksjonelle behov, eller som et fritt valg, men også tilpasset og lagret oppå allerede eksisterende institusjonelle arrangementer (Mahoney \& Thelen, 2010). Raske og omfattende endringer forklares derfor gjennom sjokk og kriser som bidrar til å delegitimere eksisterende arrangementer (Streeck \& Thelen, 2005). På denne måten må reformatorer ta hensyn til hva som er historisk og institusjonelt rimelig og akseptabelt (March \& Olsen, 1989), samt fokusere på eksterne hendelser som muliggjør stiendrende intervensjon. En generell forventning er at strukturreformer tilpasser seg tidligere reformer i UH-sektoren.

\section{UH-organisasjonenes respons på strukturreformen}

Nå skal vi se nærmere på hvordan UH-organisasjonene forholdt seg til planene om en strukturreform. Det innebærer at vi ser organisasjonsendringene fra lærestedenes ståsted. For å belyse lærestedenes argumentasjon vil følgelig perspektivet som vektlegger sammenhengen mellom organisasjoner, deres identitet og reformer, være mest relevant, 
men også perspektivet om måten organisasjoner er strukturert på, samt reformperspektivet.

Etter at ministeren lanserte planene om en strukturreform, ble UHorganisasjonen oppfordret til å beskrive sine strategiske styrker og plassere seg i et fremtidig landskap som skulle bestå av færre universiteter og høgskoler. Her analyserer vi de dokumentene lærestedene sendte til departementet, med vekt på hvilke læresteder som bruker hvilke argumenter, og hva som er innholdet i argumentene. Gjennom responsen til institusjonene blir det tydelig hvordan organisasjonsdemografi, organisasjonsstruktur og lokalisering spiller inn på institusjonenes valg, men også hvordan de forsøker å skape en balanse mellom konkurrerende målsettinger.

Analysen viser at blant høgskolene var det bare Høgskolen i Harstad (HiH) og Høgskulen i Sogn og Fjordane (HiSF) som var kritiske til fusjon. Høgskolen i Østfold (HiØ) ønsket å fusjonere, men hadde ingen aktuell fusjonspartner. I argumentasjonen legger $\mathrm{HiH}$ og HiSF vekt på at deres regionale oppgave og faglige profil ikke er forenlig med fusjoner med andre institusjoner. HiSF tviler på at deres rolle som en viktig institusjon for regionen og distriktene vil bli ivaretatt av en ledelse i Oslo og Bergen. HiSF skriver:

Profilen vår skal vere høg fagleg kvalitet og attraktive studiestader lokalisert i småskala samfunn, der vi skal vidareutvikle kompetansen vår og nytte ut dei gode vilkåra vi har for å skape engasjerande og stimulerande forskings- og loeringsmiljø med tett oppfølging av den einskilde. Vi skal utvikle forskingsbasert kunnskap og nyskaping innanfor dei yrkesfelta høgskulen utdannar til, og innanfor dei områda der HiSF har sarskilte fortrinn med basis i geografisk plassering, kompetanse og regionalt samfunns og arbeidsliv. Vurderinga vår er at HiSF $i$ dag er ein vel fungerande høgskule med god kvalitet som står fram som eit regionalt kraftsentrum, og som i stor grad har utvikla seg i samsvar med det som i si tid var målsetjingane med desentralisering av høgre utdanning i Noreg.

Blant de vitenskapelige og kunsthøgskolene ønsker kun Arkitektur- og designhøgskolen i Oslo (AHO) sammenslåing, og da med Kunsthøgskolen i Oslo (KHiO) og Norges Musikkhøgskole (NMH) for å skape en «kraftfull stemme både innen UH-sektoren, ut mot kulturfeltet og mot 
samfunnet for øvrig». De vitenskapelige høgskolene er også opptatt av at deres faglige profil og styrke ikke vil bedres gjennom sammenslåinger, og de ønsker å fortsette alene.

Noen av universitetene og de vitenskapelige høgskolene kan tenke seg å slå seg sammen med forskningsinstitutter, Universitetet i Oslo (UiO), Universitetet i Agder (UiA) og Norges miljø- og biovitenskapelige universitet (NMBU) og heller samarbeide sterkere. UiO trekker spesielt fram Universitetssykehuset som en viktig ekstern institusjon de vil samarbeide med. Blant universitetene er både Universitetet i Bergen (UiB), Norges teknisk-naturvitenskapelige universitet (NTNU) og Universitetet i Tromsø (UiT) positive til fusjoner og sterkere samarbeid. I det følgende vil vi diskutere UH-organisasjonenes ulike argumenter for reform.

Regionale og lokaliseringmessige argumenter: Ulike argumenter for reform kan brytes ned i ulike kategorier. Et interessant poeng er at mange av argumentene er tosidige, det vil si at de brukes både for å argumentere for en ny struktur og for å bevare den gamle. Et eksempel på dette er det vi har kalt regionale argumenter. Høgskolenes regionale rolle er noe som ofte brukes som argument for høgskolenes strategiske mål, og ligger til grunn for deres vurdering av fusjoner. Høgskolen i Hedmark (HiHe), Høgskolen i Nord-Trøndelag (HiNT), Høgskolen i Sør-Trøndelag (HiSF), og $\mathrm{Hi} \varnothing$ argumenterer for at en av deres viktigste oppgaver er deres nøkkelrolle i regionen for å skaffe nødvendig kompetanse, være en støttespiller for lokalt næringsliv og skape vekst i regionen. For å sikre denne rollen gjennom strukturendringene i UH-sektoren blir fusjon et alternativ for å sikre fagmiljøer med tilstrekkelig kompetanse og størrelse, og da gjerne med andre høgskoler i nærområdet (f.eks. HiNT og HiST). Som vi diskuterte ovenfor, er disse regionale argumentene de samme som HiSF og $\mathrm{HiH}$ brukte for å ikke ønske sammenslåing. En annen variant av det regionale argumentet er at $\mathrm{UH}$-institusjonene spiller en viktig rolle i å løfte utdanningsnivået i regionene. Dette understrekes blant annet av $\mathrm{HiH}$, HiHe, HiNT og UiA, der UH-organisasjonene har et samfunnsansvar for å heve et lavt regionalt utdanningsnivå.

Et generelt samfunnsperspektiv og samfunnsansvar er også noe som brukes som argument. Mens institusjonene i distriktene har et sterkt 
regionalt fokus, understreker de nye universitetene særlig, samt $\mathrm{UiO}$, at de har et nasjonalt samfunnsansvar. Dette ser vi blant annet i at det regionale aspektet løftes frem av $\mathrm{HiSF}$ og $\mathrm{HiH}$, men da for å understøtte en beslutning om ikke å fusjonere. De som bruker regionale argumenter, trekker frem at de rekrutterer studenter først og fremst fra regionen, og at studentene etter studiet søker jobb der. Særlig regionenes behov for helsefagarbeidere trekkes fram. UiT argumenterer også for sin sentrale rolle i å sikre arbeidskraft i regionen.

Et lignende argument til det regionale argumentet er det vi kan kalle distriktsperspektivet. Der regionargumentet handler om betydningen for de lokale omgivelsene, er distriktsperspektivet mest opptatt av à å knesette en motsetning til et sentrum. HiSF argumenterer slik:

Vidareføring av lokal autonomi er etter vårt syn ein føresetnad for å realisere ønska strategisk profil. Vi har vanskeleg for å sjå at det ville skjedd ei liknande satsing på å byggje attraktive studiestader og vel fungerande fagmiljø dersom studiestadane Sogndal og Førde skulle byggjast opp, styrast og leiast frå Oslo eller Bergen.

Om ikke som en direkte motsetning til distriktsargumentet, så er det også institusjoner som bruker urbanitet og geografisk nærhet til byen som et argument. Høgskolen i Bergen (HiB) og HiST mener en fusjon med universitetene vil skape sterkere institusjoner i byene («En fusjon $\mathrm{i}$ Bergen mellom UiB og HiB vil styrke Bergen som kunnskapsby»), samtidig som det også vil styrke «Vestlandet som nasjonalt tyngdepunkt». HiST argumenter på sin side for at fusjon med NTNU vil være med på å styrke «Kunnskapsbyen Trondheim».

Faglige argumenter: To typer argumenter som også henger sammen, er de som retter seg mot å styrke forskningsmiljøer, og de som retter seg mot å styrke fagmiljøer knyttet til utdanning og forskning i sammenheng. Institusjoner som i størst grad rendyrker argumenterer for styrkede forskningsmiljøer, er Høgskolen i Gjøvik (HiG), Høgskolen i Lillehammer (HiL) og HiST. De peker på at forskningsmiljøene deres vil bli styrket gjennom sammenslåing. HiG viser særlig til hvordan deres teknologifag vil bli styrket ved en sammenslåing med NTNU. HiST viser til at forskningskompetansen på NTNU vil styrke deres fagmiljøer. HiL argumenterer på følgende vis: 
I et landskap med forre institusjoner vil den fremste satsningen for å utvikle nasjonale toppmiljøer med internasjonale ambisjoner $i$ vår region voere en fusjon mellom HiL og HiG.

UiT argumenterer også for at fusjoner i landsdelen kan bidra til å styrke forskning på naturgitte fagområder i landsdelen.

Å styrke forskning faller også sammen med et argument om å styrke utdanningen ved institusjonene. Høgskulen i Stord/Haugesund (HSH) er tydelig på at deres fagmiljøer vil bli styrket med en sammenslåing med UiS. De vil få sterkere fagmiljøer til å tilby bedre utdanninger:

De utdanningene som tilbys ved HSH (grunnskolelorer- og førskoleloererutdanning, sykepleierutdanning, ingeniørfag, og økonomi og administrasjon) tilbys også ved UiS, med unntak av maritim utdanning. Høgskolen og Universitetet kan bli del av et større utdannings- og forskningsmiljø, hvor det vil vore mulig å skape synergieffekter basert på et enda tettere samarbeid. Innenfor disse fagmiljøene har vi ulike spisskompetanser som kan skape ytterligere robusthet i en felles institusjon.

Argumentet rettet mot å styrke utdanningene i samspill med forskningsmiljøene går oftest igjen. HiNT mener utdanningene vil bli styrket gjennom en sammenslåing med HiST eller Universitetet i Nordland (UiN). UiT og NTNU argumenter også for at fusjoner vil styrke utdanningene på fagområder som teknologi, lærerutdanning og profesjonsfag.

Det er relativt stor enighet blant høgskolene om at forskningsmiljøene vil bli styrket av fusjoner. HiHe argumenterer blant annet med dette, men viser også til at geografisk avstand vil være en utfordring når det gjelder å styrke fagmiljøene ved en fusjon, og at naturlige samarbeidspartnere ikke alltid finnes i det geografiske nærområdet:

I valet mellom ulike vestlandsalternativ, har vi heile tida kome attende til at HiSF i stor grad har samarbeidspartar som like mykje ligg utanfor som innafor dette geografiske området.

HiSF peker heller mot at samarbeid i like stor grad kan styrke forskningsmiljøene, og antar heller ikke at en fusjon i seg selv vil virke styrkende. For mange av de vitenskapelige høgskolene og enkelte av universitetene er økt 
faglig samarbeid fremsatt som et alternativ til fusjon. Til dette hører også et argument om arbeidsfordeling basert på egenart. Dette brukes i hovedsak som et argument mot sammenslåing. Høgskolen i Hedmark skriver:

Først og fremst ønsker vi å utvikle og styrke mer forpliktende samarbeid med andre - både høyere utdanningsinstitusjoner og arbeids- og samfunnsliv. Slikt samarbeid skal fremme høy kvalitet $i$ utdanning og forskning, men også bidra til profilering og arbeidsdeling innenfor ulike fagområder og til å styrke arbeidslivsrelevans- og arbeidslivstilknytning

Enkelte institusjoner ser også forskning og utdanning i sammenheng i sine vurderinger av fusjoner. HSH mener det er enklere å dimensjonere utdanningene med en sammenslåing med UiS. UiA er et eksempel på en institusjon som mener samarbeid og ikke fusjoner vil hjelpe dem med det samme:

UiAs utfordringer knyttet til f.eks. studenters og ph.d.-stipendiaters tidsbruk, vil ikke kunne løses ved sammenslåinger med andre institusjoner. De problemene må søkes løst ved intern fokusering og prioriteringer, og i gode samarbeidsorganiseringer med nasjonale og internasjonale samarbeidspartnere på de ulike fagområdene.

Ved UiT argumenteres det på samme måte:

For å unngå ressurssløsende konkurranse mellom institusjonene er det ønskelig med en diskusjon om ansvarsdeling innen både forskning, utdanning og infrastruktur. Videre bør forpliktende samarbeidsformer mellom forskningsinstitusjoner styrkes.

Studenter: I forlengelsen av vektleggingen av sammenhengen mellom forskning og utdanning pekes det også på studentkonkurranse og rekruttering som viktig. Dette var også et sentralt område i KDs argumentasjon om små og sårbare miljøer. HiNT og HiST legger vekt på at en sammenslåing vil styrke rekrutteringen av studenter i en samlet Trøndelagsregion. HiST viser til at tilhørighet til studentbyen Trondheim er en fordel for rekruttering, men at konkurransen med NTNU er umulig. En sammenslåing med NTNU vil løse dette. HiNT viser til at sammen med HiST kan de dekke regionens kompetansebehov, og de håper på en bedring i 
søkningen til institusjonen. Særlig bekymring knyttes til rekruttering av studenter når endrede kompetansekrav i blant annet lærerutdanningen blir innført:

Innføring av karakterkrav på faglorerutdanningene fra høsten 2015 vil - ut ifra dagens søkermasse, gi en nedgang på ca. 20-30 \% kvalifiserte søkere, mens forslaget om innføring av 4 i Høgskolen i Nord-Trøndelag matematikk for opptak på GLU fra høsten 2016, vil gi en nedgang på ca. $15 \%$. Dette vil vere krevende for disse utdanningene, dersom tiltak ikke iverksettes.

Internasjonalisering: Internasjonalisering brukes også som argument for og mot fusjon. Norges Handelshøyskole (NHH) og Samisk høgskole (SH) hevder at økt samarbeid med utlandet vil styrke fagmiljøene, og bruker internasjonalisering som et argument mot fusjon. UiA, NMBU og UiO har også internasjonale ambisjoner, og ser ikke fusjoner som en løsning på dette. SH, UiO, NMBU og NHH har alle fagfelt der de hevder seg internasjonalt, og vil i større grad orientere seg internasjonalt enn å fusjonere med andre norske UH-institusjoner. Nasjonale fusjoner ses ikke som forenlig med en slik strategi. UiB og NTNU viser til at fusjoner nasjonalt og lokalt for dem også kan innebære en midlertidig svekkelse av deres internasjonale faglige nivå.

Samtidig er internasjonalisering også et argument som flere bruker for å argumentere for en fusjon. HiG, HiL, HiST og AHO har internasjonale ambisjoner de mener vil bli styrket ved en sammenslåing. I redegjørelse for en mulig sammenslåing med $\mathrm{KHiO}$ og $\mathrm{NMH}$ heter det fra $\mathrm{AHO}$ :

En sammenslått institusjon vil kunne understøtte og styrke internasjonaliseringsarbeidet, både når det gjelder studentrekruttering og faglig rekruttering. Det vil vere viktig at det enkelte fagmiljø innenfor den nye institusjonen kan videreføre og styrke sine spesifikke faglige internasjonale nettverk.

Institusjoner som vektlegger internasjonalisering gjennom fusjonering, argumenterer for muligheter til økt internasjonal finansiering av forskningsprosjekter. Samtidig brukes også argumentet om internasjonalisering for å peke på en orientering internasjonalt, og at de dermed ser utover etter partnere, ikke innover i Norge. 


\section{Reform - hva så?}

Som eksemplene ovenfor har vist, er det en rekke ulike argumenter som er brukt, og som på ulikt vis svarer på «oppgaven» gitt av Kunnskapsdepartementet. Ikke overraskende ser vi at de samme argumentene brukes for og mot sammenslåing. Hvordan skal møtet mellom reformer og UH-organisasjoner således forstås? Tidligere skisserte vi ulike organisasjonsteoretiske perspektiver og påpekte blant annet at hvordan reformer organiseres, påvirker selve reformprosessen, ikke minst gjennom at reformprosessen i seg selv kan være bevisst organisatorisk designet for å oppnå visse mål. Strukturreformen fremstår som godt politisk håndverk i denne betydningen: Den følger opp tidligere UH-reformer samtidig som den legger opp til bred involvering fra lærestedene, der de selv var med på å tegne det fremtidige kartet for norsk UH-sektor i sine svar til departementets forslag til reform og reformprosess. Denne form for desentralisert reformstruktur mobiliserer berørte parter og deres argumenter, og har en tendens i dette tilfellet til å mobilisere motstand mot reform. En slik reformstruktur påvirker således hvilke aktører og argumenter som oppfattes som legitime og effektive, og dermed også selve reformprosessen. Analysen av lærestedenes argumentasjon viser et sammensatt sett av begrunnelser for sammenslåingene, ikke minst er det interessant at økt regional betydning brukes som argument både for og mot å fusjoner med andre UH-institusjoner. Reformen mobiliserte på mange måter allerede eksisterende oppfatninger ved UH-institusjonene, og således ble samme løsning svar på ulike problemer. Vi kan anta at den desentraliserte prosessen, der lærestedene selv ble bedt om å finne sin plass, bidro til at det enkelte lærested vektla de argumentene som passet best med deres identitet, historie og tradisjon - innenfor rammen av det de oppfattet som mest hensiktsmessig for å fremme deres egne interesser. Vi ser også tegn til at fusjonene som også omfatter flere UH-organisasjoner, ble mer kompliserte enn reformer som omfattet færre organisasjoner. Flercampusreformer ble derfor gjennomgående mer komplekse. For eksempel ser det ut til at flercampusfusjonene som for eksempel NTNU og UiT kan ha mobilisert flere aktører og argumenter, og dermed ble vanskeligere å styre enn fusjoner mellom to parter. 
Vi kan også anta at lærestedene tilpasset forventningene til reformen til «globale» oppskrifter på hvordan «moderne» organisasjoner bør se ut. Dette er tydelig i forståelsen av at små og sårbare fagmiljøer var en problembeskrivelse som i liten grad bestrides og fremskynder fusjonsprosessene ved lærestedene. Reformen kan derfor ses som uttrykk for myter og moter som assosieres med det moderne - slik som størrelse og flercampusuniversitetet. Når reformer innehar institusjonaliserte løsninger, har de større sannsynlighet for å spre seg relativt motstandsløst til UH-organisasjonene. På denne måten blir organisasjonsendringene og strukturreformer løsningsdrevet snarere enn problemdrevet.

I tillegg kan vi fortolke reformargumentene i lys av at de enkelte lærestedene har utviklet sin særegne organisatoriske kapasitet for å håndtere reformer og for å lære av egne erfaringer, og dermed også for å etablere sin egen institusjonelle sti over tid. Når organisasjonens egen historie har blitt kodet inn i egne regler og rutiner, vil lokale argumenter lettere bryte gjennom i nasjonale reformer. Betoningen av regionale argumenter kan ses som uttrykk for dette. I tillegg kan vi tolke ministeren dit at han som institusjonell designer tok hensyn til hva som var rimelig og akseptabelt når han ba UH-organisasjonene foreslå sine egen plass. Likevel ble UH-institusjonenes organisatoriske kapasitet benyttet for å mobilisere deres historiske rolle i møte med en standardisert nasjonal reform.

Samlet sett viser studien at målkonflikter ofte ikke organiseres bort, men aksentueres i møte med reformer (Ansell et al., 2017). Balansen mellom målene varierte noe etter UH-institusjonenes organisering og institusjonelle egenart, samt også noe etter hvordan selve reformene artet seg på det enkelte lærestedet. Gjennomgående synes likevel etablerte måter å «gjøre ting på» i stor grad å forklare hvordan UHorganisasjonene møtte strukturreformen. Disse møtene reflekterer også iboende interne styringslogikker i UH-organisasjonene, preget av ulike prinsipper for organisering av myndighetsstruktur og en sammensatt og kompleks organisasjonsstruktur - ikke ulikt hybride og turbulente organisasjoner. Et effektivt organisasjonsdesign for å realisere konkurrerende målsettinger handler derfor ofte om å finne balanse mellom konkurrerende målsettinger og løsninger. Det kan argumenteres for at det ikke er mulig eller ønskelig å organisere seg bort fra målkonflikter, 
men at organisasjonsendringer handler om å skape organisasjonsformer som kan håndtere spenninger på en måte som ikke blokkerer institusjonene.

\section{Referanser}

Abrahamson, E. (1991). Managerial fads and fashions - the diffusion and rejection of innovations. Academy of Management Review, 16(3), 586-612.

Ansell, C., Boin, A. \& Farjoun, M. (2015). Dynamic conservativism: How institutions change to remain the same. I M. S. Kraatz (red.), Institutions and ideals: Philip Selznick's legacy for organizational studies. Bingley: Emerald.

Ansell, C., Trondal, J. \& Øgård, M. (Red.). (2017). Governance in turbulent times. Oxford: Oxford University Press.

Bleiklie, I. \& Frølich, N. (2014). Styring og ledelse i politikk om høyere utdanning. I N. Frølich, E. Hovdhaugen \& L. I. Terum (Red.), Kvalitet, kapasitet og relevans. Utviklingstrekk i norsk høyere utdanning. Oslo: Cappelen Damm Akademisk.

Boer, H. d., File, J., Huisman, J., Seeber, M., Vukasovic, M. \& Westerheijden, D. F. (Red.) (2017). Policy analysis of structural reforms in higher education. Prosesses and outcomes. London: Palgrave Macmillan.

Brunsson, N. (1989). The organization of hypocrisy. San Francisco: Wiley.

Castells, M. (2001). Universities as dynamic systems of contradictory functions. I J. Muller, N. Cloete \& S. Badat (Red.), Challenges of globalization. South African debates with Manuel Castells (s. 206-223). Cape Town: Maskew Miller Longman.

Christensen, T. (2011). University governance reforms: Potential problems of more autonomy? Higher Education, 62(4), 503-517. https://doi.org/10.1007/s10734-0109401-Z

DiMaggio, P. J. \& Powell, W. W. (1983). The iron cage revisited. Institutional isomorphism and collective rationality in organizational fields. American Sociological Review, 48, 147-160.

Egeberg, M. \& Trondal, J. (2018). An organizational approach to public governance. Oxford: Oxford University Press.

Elken, M. \& Frølich, N. (2016). Pulling the plug in a bathtub - the big consequences of a small change in Norwegian higher education. I J. Huisman, H. de Boer, D. Westerheijden, M. Vukasovic, M. Seeber \& J. File (Red.), Policy analysis and structural reforms in higher education: Examining policy success and failure. New York: Springer International.

Elken, M. \& Røsdal, T. (2015). Organisering på fakultetsnivå: Tilleggsanalyse i forlengelsen av fase 2-rapporten HiOAs organisasjonsdesign for framtiden. Hentet fra https://www.nifu.no/publications/1245882/ 
Fligstein, N. (2001). Organizations: Theoretical debates and the scope of organizational theory. Hentet fra https://sociology.berkeley.edu/sites/default/files/ faculty/fligstein/inter.handbook.paper.pdf

Frølich, N. (red.) (2015). Hva skjer i universiteter og høgskoler? Perspektiver fra vitenskapelig ansatte og studenter. Oslo: Universitetsforlaget.

Greenwood, R., Raynard, M., Kodeih, F., Micelotta, E. R. \& Lounsbury, M. (2011). Institutional complexity and organizational responses. The Academy of Management Annals, 5(1), 317-371.

Harvey, L. \& Green, D. (1993). Defining quality. Assessment \& Evaluation in Higher Education, 18(1), 9-34.

Krücken, G. \& Meier, F. (2006). Turning the university into an organizational actor. I G. S. Drori, J. W. Meyer \& H. Hwang (Red.), Globalization and organization: World society and organizational change. Oxford: Oxford University Press.

Kunnskapsdepartementet. (2015). Konsentrasjon for kvalitet. Strukturreform i universitets- og høyskolesektoren. (Meld. St. 18 (2014-2015)). Hentet fra https:// www.regjeringen.no/no/dokumenter/meld.-st.-18-2014-2015/id2402377/

Larsen, I. M. (1999). Høgskolestyrets styringsrolle og høgskolerådets rådgivningsrolle. Delrapport. Oslo: Norges forskningsråd.

Larsen, I. M., Maassen, P. \& Stensaker, B. (2009). Four basic dilemmas in university governance reform. Higher Education Management and Policy, 21(3), 1-18.

Lekve, K., Elken, M., Røsdal, T. \& Gleinsvik, A. (2014). HiOAs organisasjonsdesign for fremtiden: Ekstern underveisevaluering av styring og ledelse, faglig og administrativ organisering, Høgskolen i Oslo og Akershus - Fase 2.

Lekve, K., Kyvik, S., Stensaker, B., Vabø, A., Elken, M., Røsdal, T., \& Gleinsvik, A. (2014). HiOA underveis mot strategiske mål? Ekstern underveisevaluering av styring og ledelse, faglig og administrativ organisering, Høgskolen i Oslo og Akershus.

Maassen, P. \& Stensaker, B. (2003). Interpretations of self-regulation: The changing state-higher education relationship in Europe. The dialogue between higher education research and practice. I R. Begg (Red.), The dialogue between higher education research and practice (s. 85-95), Dordrecht: Springer.

Mahoney, J. \& Thelen, K. (2010). A theory of gradual institutional change. I J. Mahoney \& K. Thelen (Red.), Explaining institutional change. Cambridge: Cambridge University Press.

March, J. G. \& Olsen, J. P. (1989). Rediscovering institutions. The organizational basis of politics. New York: Free press.

Meyer, J. W., Boli, W. J., Thomas, G. M. \& Ramirez, F. O. (1997). World society and the nation-state. American Journal of Sociology, 103(1), 144-181. 
Meyer, J. W. \& Rowan, B. (1977). Institutional organizations: Formal structures as myth and ceremony. American Journal of Sociology, 83, 340-363.

Musselin, C. (2007). Are universities specific organisations? I G. Krücken, A. Kosmützky \& M. Torka (Red.), Towards a multiversity? Universities between global trends and national traditions. Bielefeld: Transcript Verlag.

Olsen, J. P. (2017). Democratic accountability, political order, and change. Oxford: Oxford University Press.

Paradeise, C., Reale, E., Bleiklie, I. \& Ferlie, E. (Red.) (2009). University governance. Western European comparative perspectives. Dordrecht: Springer.

Pfeffer, J., \& Salanick, G. R. (1978). The external control of organizations. A resource dependence perspective. New York: Harper and Row.

Pruvot, E. B., Estermann, T. \& Mason, P. (2015). University mergers in Europe.

Regjeringen (2014a). Klare prioriteringer i høyere utdanning og forskning. (pressemelding, 14.01.2014). Hentet fra https://www.regjeringen.no/no/aktuelt/ klare-prioriteringer-i-hoyere-utdanning-/id749226/

Regjeringen (2014b). Bedre kvalitet i høyere utdanning (tale/innlegg, 14.01.2014). Hentet fra https://www.regjeringen.no/no/aktuelt/bedre-kvalitet-i-hoyereutdanning/id751716/

Røsdal, T., Elken, M., Stensaker, B. \& Gunnes, H. (2015). Evaluering av faglig understruktur ved Høgskolen i Bergen. Oslo: NIFU.

Sahlin, K. \& Wedlin, L. (2008). Circulating ideas: Imitation, translation and editing. I R. Greenwood, C. Oliver, K. Sahlin \& R. Suddaby (Red.), Handbook of organizational institutionalism. Los Angeles: Sage.

Seeber, M., Lepori, B., Montauti, M., Enders, J., de Boer, H., Weyer, E., ... Reale, E. (2015). European universities as complete organizations? Understanding identity, hierarchy and rationality in public organizations. Public Management Review, 17(10), 1444-1474. https://doi.org/10.1080/14719037.2014.943268

Selznick, P. (1957). Leadership in administration. New York: Harper \& Row.

Simon, H. (1957) [1945]. Administrativ behavior (2. utg, red.). New York: Macmillan.

Stjernøutvalget. (2008). Sett under ett. Ny struktur i høyere utdanning (NOU 2008: 3) Oslo: Kunnskapsdepartementet.

Streeck, W. \& Thelen, K. (2005). Introduction: Institutional change in advanced political economies. I W. Streeck \& K. Thelen (Red.), Beyond continuity. Oxford: Oxford University Press.

Tellmann, S. M., Røsdal, T. \& Frølich, N. N. (2016). Gjennomgang av organisasjonsstrukturen ved UiT Norges arktiske universitet. Oslo: NIFU.

Tolbert, P. S. \& Zucker, L. G. (1983). Institutional sources of change in the formal structure of organizations: The diffusion of civil service reform, 1880-1935. Administrative Science Quarterly, 28(1), 22-39. 
KAPITTEL 3

Waldo, D. (1952). Development of theory of democratic administration. American Political Science Review, 46(1), 81-103.

Whitley, R. (2008). Universities as strategic actors: Limitations and variations. I L. Engwall \& D. Weaire (Red.), The university in the market (s. 23-37). London: Portland Press Ltd. 


\title{
Universitet og region - en sammensatt relasjon
}

\author{
Peter Arbo
}

Universitetet i Tromsø - Norges arktiske universitet

\begin{abstract}
Over the past 50 years, there has been a large-scale expansion and decentralization of higher education in Norway. Today, there are universities throughout the country, and the institutions are expected to serve as drivers for regional development. This chapter explores the many-faceted and symbiotic relationship between university and region. The chapter is based on a comprehensive literature review and the author's own empirical research. First, it examines the advantages and disadvantages that a region may have from a university. Next, the lens is turned and the question is: What difference can the region make to the university? Six major transformations outside and within the universities currently changing the ways in which universities and regions interact are then discussed. As a result of these changes, universities are facing increasingly complex demands and expectations, and the final part of the paper elucidates some of the dilemmas that this creates for the governance of the institutions.
\end{abstract}

Keywords: university, region, interaction, transformation of higher education

\section{Innledning}

Universiteter har alltid hatt en særskilt betydning for den byen eller regionen der kjernevirksomheten er lokalisert. Forholdet mellom et universitet og det omkringliggende samfunn kan i perioder være spenningsfylt, men kunnskapsinstitusjonene tiltrekker seg talentfulle mennesker, de gir $ø$ kt økonomisk omsetning, de bidrar til spredning av nye ideer, og de kaster ofte glans over sin hjemby (Bender, 1988). Bak opprettelsen av de

Sitering av dette kapitlet: Arbo, P. (2019). Universitet og region - en sammensatt relasjon. I J. P. Knudsen \& T. Lauvdal (Red.), Geografi, kunnskap, vitenskap. Den regionale UH-sektorens framvekst og betydning (s. 99-130). Oslo: Cappelen Damm Akademisk. https://doi.org/10.23865/noasp.73.ch4.

Lisens: CC BY 4.0 
fleste høyere læresteder ligger det derfor et langvarig lokalt engasjement. Det samme gjelder for de eldre skolene og vitenskapelige institusjonene som universitetsetableringen bygger på. Alle universitetshistoriene starter typisk nok med en lang beretning om forhistorien, som kan omfatte vitenskapsselskap, lærerskoler, museer og observatorier. Men om det ligger en lokal innsats til grunn, hever det seg alltid en høyere himmel over universitetene. I sin virksomhet og orientering peker de langt ut over de nærmeste by- og regiongrensene. Så selv om et universitet er lokalisert $i$ en region, er det ikke primært til for regionen.

\section{Den regionale dimensjonen}

De europeiske universitetene har helt siden middelalderen vært bærere av en kunnskap med allmenne gyldighetsfordringer. Disse var først forankret i de hellige skrifter og antikkens mestere, men ble etter hvert basert på eksperimentering, observasjon og kritisk etterprøving. Fokuset skiftet fra bevaring og overlevering av kunnskap til generering av ny kunnskap. Kunnskapen tilhørte ikke en eksemplarisk fortid, men en framtid som med fornuftens hjelp var åpen for perfeksjonering (Koselleck, 1988). På 180o-tallet ble universitetene sentrale hevstenger for nasjonal modernisering. Med de tyske universitetene som forbilde søkte de å kombinere en internasjonal lærdomskultur med praktiske embetsutdanninger og en økende vitenskapelig aktivitet (Collett, 2004). Universitetene tjente de framvoksende nasjonalstatene og fikk til gjengjeld statlig støtte og en betydelig faglig autonomi. Både vitenskapen og den moderne staten sto for det allmenne, slik Dag Østerberg (2015) har formulert det. De var tvillinginstitusjoner; begge barn av opplysningstiden (Frank \& Meyer, 2007).

Det Kongelige Frederiks Universitet er et typisk eksempel. Universitetet, som ble etablert i 1811, skulle først og fremst sikre utdanning av embetsmenn i eget land. Professorene ble selv embetsmenn, og den nye institusjonen fikk en avgjørende betydning for oppbyggingen av en norsk statsforvaltning (Collett, 1999; Slagstad, 2006). Fra andre halvdel av 180o-tallet ble det også lagt økende vekt på forskning, med en tilhørende akademisk spesialisering. Universitetet kastet dermed lys over ulike sider ved den nye nasjonen - naturforhold, befolkning, næringsveier, historie, språk og kultur - noe som ble viktig i nasjonsbyggingen. 
Det nasjonale ble igjen understreket ved etableringen av de nye høgskolene som kom i perioden fra inngangen til 1900-tallet og fram til andre verdenskrig, da vitenskap og teknologi etter hvert ble tettere koblet. Det var Norges Landbrugshøiskole (1897), Norges Tekniske Høiskole (1910), Noregs Lærarhøgskule (1922), Norges Tannlægehøiskole (1928), Norges Veterinærhøiskole (1935) og Norges Handelshøiskole (1936). Alle markerte en økende vitenskapeliggjøring av praktiske håndverksyrker, som nå gradvis fikk en akademisk status, og alle markerte en mobilisering av kunnskap og nye former for ekspertise for landets utvikling (Slagstad, 2007). Fram til andre verdenskrig var det en selvfølge at de sentrale kunnskapsinstitusjonene skulle være nasjonale både i navnet og i gavnet. Universitetet i Bergen, som ble etablert i 1946 etter en mangeårig universitetskamp, føyde seg i all hovedsak inn i den gamle universitetstradisjonen (Forland \& Haaland, 1996).

Det var først på 1960-tallet at utdanningspolitikken begynte å få en eksplisitt regional dimensjon. Demokratiske og egalitære verdier var på frammarsj i hele Europa, og det var blitt bred aksept for at staten skulle bidra til industriutvikling og utjevning av levekår. Det gjaldt også geografiske ulikheter. I Norge ble Utbyggingsprogrammet for Nord-Norge i 1961 avløst av Distriktenes utbyggingsfond. I den rådende distriktspolitiske tenkningen ble oppmerksomheten rettet mot alt det distriktene manglet for å kunne bli moderne. Utdanning ble i økende grad betraktet som en kilde til økonomisk og sosial framgang, og både i OECD og på nasjonalt nivå ble utdanningsplanlegging og utdanningsreform satt på dagsordenen (Eide, 1995). Dette omfattet alle nivåer, inklusive høyere utdanning, som nå ble behandlet som en felles postgymnasial eller tertiær kategori. Det var klart at de store etterkrigskullene og den generelle troen på utdanning ville gi økt tilstrømming til de høyere lærestedene. Samtidig ble det pekt på at en bred velferdsstatlig utbygging og en utvikling i retning av mer «intelligensindustri» ville gi et større behov for høyt utdannet arbeidskraft. Mye talte imot å kanalisere hele den forventede veksten inn i de eksisterende universitetene og vitenskapelige høgskolene. Det kom også stadig sterkere krav fra «utdanningsfattige» landsdeler om bedre utdanningsmuligheter i egen region og en bedre fordeling av akademisk arbeidskraft. 
Ruud-komiteen (1965), som fikk i oppdrag å utrede forutsetningene og behovet for å etablere Universitetet i Tromsø, representerte et viktig vendepunkt. Komiteen støttet seg på en undersøkelse gjennomført av ett av komitemedlemmene - Torstein I. Bertelsen, professor i medisin ved Universitetet i Bergen og opprinnelig fra Harstad. Han publiserte i 1963 en artikkel i Tidsskrift for Den norske logeforening, der han dokumenterte den nære sammenhengen mellom fødested, studiested og arbeidssted for norske leger (Bertelsen, 1963). Konklusjonen var klar: Skulle man avbøte den store legemangelen i nord, hjalp det verken med pisk eller gulrot. I stedet måtte det etableres en medisinerutdanning i Nord-Norge som kunne gi nordnorsk ungdom muligheten til å studere og finne sitt virke i egen landsdel. Det samme ble antatt å være gyldig for andre typer universitetsutdannet arbeidskraft. Dette understreket behovet for en desentralisering av høyere utdanning, noe som ble fulgt opp gjennom opprettelsen av Universitetet i Tromsø og Ottosen-komiteens forslag om etablering av såkalte distriktshøgskoler. De nye tilbudene reflekterte dels et ønske om å skape noe nytt i forhold til de etablerte lærestedene, og dels var de et ledd i en distriktspolitisk innsats for å gi lik rett til høyere utdanning, heve utdanningsnivået og styrke tilgangen på universitets- og høgskoleutdannet arbeidskraft $\mathrm{i}$ alle deler av landet.

I dag har vi en vel utbygd universitets- og høgskolesektor. Femti år etter at de første distriktshøgskolene ble opprettet, er alle de tidligere høgskolene i ferd med å bli innlemmet i eller omgjort til universiteter. Dagens universitets- og høgskolelov gjør det klart at alle institusjonene skal ivareta utdanning og forskning på høyt internasjonalt nivå. De forventes å spre og formidle resultatene av forskningen og bidra til at resultatene omsettes i innovasjon og økt verdiskaping. De skal også tilby videre- og etterutdanning, og de skal ha et omfattende samarbeid med andre vitenskapelige institusjoner, næringsliv, myndigheter og internasjonale organisasjoner. Dessuten blir det slått fast at institusjonene skal samarbeide med lokalt og regionalt samfunns- og arbeidsliv.

Jeg skal i dette kapitlet se nærmere på samspillet mellom universitet og region. Jeg vil først drøfte hvilke fordeler og ulemper en region kan ha av et universitet. Så vil jeg snu på det og drøfte hvilke fordeler og ulemper et universitet kan ha som følge av en tett regional tilknytning. Deretter 
peker jeg på en del sentrale endringsprosesser i og utenfor høyere utdanning som skaper nye vilkår for samhandling. Det vil si at jeg prøver å se framover og vurdere konsekvensene av pågående transformasjoner. Avslutningsvis peker jeg på noen dilemmaer, særlig for de som skal lede kunnskapsinstitusjonene. Synspunktene som presenteres, er basert på egen forskning og erfaringene fra å delta i diverse styrer, råd og utvalg innenfor sektoren.

\section{Universitetets betydning for regionen}

Det foreligger både nasjonalt og internasjonalt et stort antall studier av universiteter og deres regionale samspill og effekter (se bl.a. Arbo \& Benneworth, 2007; Benneworth, 2019; Benneworth \& Fitjar, 2019; Drucker \& Goldstein, 2007; Florax, 1992; Huggins \& Johnston, 2009; Nilsson, 2006; Pinheiro, Benneworth \& Jones, 2012; Rutten, Boekma \& Kuipers, 2003; Sæther, Mønnesland, Onsager, Sørlie \& Arbo, 200o). Dette ble et populært forskningstema fra midten av 1980-tallet, da det internasjonalt ble en økende interesse for forskningsbasert innovasjon og søkelyset ble rettet mot Silicon Valley, Bostons Route 128, Cambridge i Storbritannia og andre suksessrike høyteknologisentre (Arbo \& Selstad, 2004; Segal Quince Wicksteed, 1985; Tatsuno, 1986; Saxenian, 1996). De fleste studiene har vært opptatt av å dokumentere hvordan universitetene fungerer som drivkraft for regional utvikling. I et forsøk på å syntetisere denne litteraturen har jeg selv pekt på ti gunstige effekter som en universitetsetablering kan ha, og jeg har brukt Universitetet i Tromsø (UiT) som eksempel (Arbo, 2011; NOU 2008: 3, kapittel 16). UiT er en institusjon som kommer i en mellomposisjon mellom de gamle, etablerte universitetene og de nye, og som er godt egnet for å belyse forholdet mellom universitet og region. La meg kort gjennomgå de viktigste effektene.

\section{Potensielle gevinster for regionen}

Et universitet har for det første en økonomisk multiplikatoreffekt, knyttet til de inntekts- og etterspørselsvirkningene som oppstår. Gjennom statlige bevilgninger, midler fra forskningsråd og EU samt andre bidrags- og oppdragsprosjekter er institusjonen med på å tilføre regionen inntekter. 
En stor del av disse blir brukt regionalt, noe som gir økonomiske ringvirkninger. UiT Norges arktiske universitet hadde for eksempel i 2018 en omsetning på knapt fire milliarder kroner. Det meste av dette går til å lønne de rundt 4000 ansatte og til å drifte bygninger, fartøy og utstyr. Universitetet er dermed ikke bare en stor og viktig arbeidsplass i seg selv, men bidrar til å opprettholde aktiviteten innenfor varehandel, transport, bygg og anlegg, hotell og restaurant og en rekke andre bransjer som leverer varer og tjenester til UiT, de ansatte og deres familier. På samme måte er skatteinntektene vesentlige for å ivareta det kommunale tjenestetilbudet. De 16500 studentene skal også bo og leve gjennom studieåret, basert på egne midler og støtte fra Lånekassen, og i tillegg kommer de mange tilreisende i forbindelse med møter, konferanser og andre faglige arrangementer.

For det andre har et universitet en mobiliseringseffekt. Når ungdom har utdanningsmuligheter i egen region, og de ikke må reise langt av gårde for å studere, vil flere velge å satse på høyere utdanning. Institusjonene påvirker med andre ord studiebøyeligheten; de virker utdanningsmobiliserende (Fulsås, 1993). Felles for de aller fleste lærestedene er derfor at de henter en stor del av studentene sine fra egen region (Stambøl, 2011). Ifølge UiTs Felles studentsystem 2016/2017 kom 66 prosent av studentene fra Nord-Norge, 22 prosent fra Sør-Norge og 12 prosent fra utlandet. ${ }^{1}$ Dette mønsteret har vært ganske stabilt over flere år. I Troms og Finnmark velger hovedtyngden av de som søker seg til høyere utdanning, å studere ved UiT.

Et universitet har for det tredje en tilbudseffekt. Hovedoppgaven er å gi utdanning, og de ferdig utdannede kandidatene gir i neste runde et større tilbud av kompetent arbeidskraft i regionen. Både offentlige og private virksomheter høster dermed fordelen av en bedre kompetansetilgang. Tidligere var det et stort problem å rekruttere og holde på akademisk arbeidskraft i Nord-Norge, men dette har endret seg. UiT, medregnet de innfusjonerte høgskolene i Tromsø, Finnmark, Harstad og Narvik, utdanner årlig omkring 2700 kandidater (bachelor, master, ph.d.). Kandidatundersøkelsen 2017 for UiT (Kantar TNS, 2017) viste at ett til tre

1 Her er førstegangsregistrert adresse ved søknad til UiT lagt til grunn. 
år etter endt utdanning var en del av kandidatene fortsatt under utdanning, i permisjon eller lignende, men rundt 8 o prosent var i jobb. Av disse arbeidet 71 prosent i Nord-Norge. Av de nordnorske studentene var det hele ni av ti som fant seg jobb i landsdelen, mens det blant de som kom fra andre deler av landet, bare var fire av ti som var blitt igjen i nord. Helt i tråd med hva Bertelsen i sin tid fant for norske leger, ser vi altså at mange av studentene forblir i den regionen der de har vokst opp og tatt sin utdanning (se også Gythfeldt \& Hagen, 2013; Røbert, 2014).

Bedre kompetansetilgang gir større utviklingsmuligheter for næringsog arbeidslivet i regionen. Her vil de økonomiske effektene være avhengig av virksomhetenes evne til å fange opp, utnytte og omsette denne kompetansen i form av nyskaping og omstilling. På mange områder er det likevel klart at kompetansetilgangen direkte bidrar til et bedre tjenestetilbud til befolkningen og dermed har en regional serviceeffekt. Det gjelder innenfor helse og omsorg, utdanning, offentlig administrasjon, planlegging og alle andre serviceytelser der formell kompetanse er utslagsgivende. Kandidatundersøkelsen 2017 for UiT viste at to tredeler av de uteksaminerte kandidatene jobbet i offentlig sektor, mens en tredel jobbet i privat sektor. Da Universitetet i Tromsø ble vedtatt opprettet, var utbyggingen av sykehuset, som tjener som universitetsklinikk, en viktig del av beslutningen. Serviceeffekten er dermed også knyttet til den generelle utbyggingen og oppgraderingen av de institusjonene som leverer tjenester til befolkningen. I dag er sykehusene i Tromsø, Harstad og Narvik en del av Universitetssykehuset Nord-Norge, mens deler av legeutdanningen også foregår i Bodø, Alta, Hammerfest og Karasjok.

Et universitet kan for det femte ha en magneteffekt. Det vil si at universitetet er med på å tiltrekke seg annen virksomhet som ønsker å være lokalisert nær institusjonen på grunn av de rekrutterings- og samarbeidsmulighetene som dette gir. Etableringen av UiT har for eksempel brakt en rekke nye forskningsorienterte virksomheter til Tromsø, slik som Norut, Nofima, Havbruksstasjonen, Havforskningsinstituttet og Siva innovasjonssenter Tromsø. UiT var også en sterk pådriver for flyttingen av Norsk Polarinstitutt fra Oslo til Tromsø og for opprettelsen av Framsenteret, som nå blant annet huser avdelingskontorene til Norsk institutt for naturforskning, Norsk institutt for luftforskning og Norsk 
institutt for kulturminneforskning. Likeså har enkelte private bedrifter kommet til Tromsø, slik som Microsoft.

For det sjette kan et universitet ha en knoppskytningseffekt. Med det sikter jeg til at nye foretak springer ut av universitetet, basert på den forskningen og kompetansen som utvikles. Dette vil ofte skje i et samspill med de andre kunnskapsinstitusjonene som er bygd opp. UiT og det øvrige forskningsmiljøet i Tromsø har for eksempel bidratt til etableringen av mer enn 80 nye bedrifter (Arbo, 2018). Hovedtyngden er innenfor marin og medisinsk bioteknologi, akvakultur og IKT koblet til satellittkommunikasjon, jordobservasjon og telemedisin. Disse bedriftene gir utvidete jobbmuligheter for høyt utdannede kandidater, og mange av dem opprettholder en nær tilknytning til de forskningsmiljøene som de er sprunget ut av.

Et universitet er for det sjuende en viktig møteplass, noe som gjør at det har en nettverkseffekt. Gjennom studier, veiledning, forskningsprosjekter, kollegialt samarbeid, konferansedeltakelse og utvekslinger blir det skapt kontakter og bygd nettverk. Effekten er ikke lett å måle, men det er liten tvil om at denne nettverksbyggingen er med på å styrke den sosiale kapitalen. Utvidete samhandlingsnett gir tilgang til informasjon og andre ressurser, og de bidrar til å opparbeide tillit og underlette koordinering. Mange av de som har tatt sin utdanning ved et studiested, blir viktige brohoder til andre kulturer og miljøer når studietiden er over. Dette har ikke bare verdi for universitetet, men også for den byen og regionen som universitetet er en del av.

Som en åttende effekt vil jeg trekke fram at et universitet gjerne har en kulturell miljøeffekt. Det setter sitt preg på omgivelsene i form av arkitektur, kunst- og kulturliv, uteliv og frivillig foreningsinnsats. De mange studentene skaper et aktivt og levende miljø, og sammen med de ansatte og deres familier gjør de studiestedene til sentre for rikholdige kulturaktiviteter. Hadde ikke Tromsø vært universitetsby, ville for eksempel neppe Tromsø internasjonale filmfestival, Nordlysfestivalen, Buktafestivalen, Ordkalotten og mange andre evenementer ha eksistert.

Et universitet kan for det niende ha en politisk effekt. Jeg tenker her på at universitetet bygger og formidler kompetanse som har betydning for samfunnets selvforståelse og veivalg. Gjennom forskning, 
utredningsarbeid og deltakelse i det offentlige ordskiftet er institusjonen med på å tematisere ulike spørsmål som angår regionen. UiT har for eksempel bidratt til å løfte fram det nordnorske, det samiske og det arktiske. Dette gjør at universitetet ofte fungerer som et regionalt talerør og en politisk premissgiver i mange sammenhenger. Universitetet former agendaer og identiteter, og det bringer fram nye stemmer.

Til sist bør det nevnes at et universitet kan ha en ikke ubetydelig symbolsk imageeffekt. Det er en av grunnene til at mange regioner har ivret for å bli universitetsregion. Universitetet er med på å gi regionen høyere status og prestisje. Bare institusjoner akkreditert som universitet kan i dag bruke denne betegnelsen, og ved å ha en slik kunnskapsinstitusjon signaliseres det at regionen er en del av det moderne kunnskapssamfunnet. Stortingsvedtaket i 1968 om å opprette UiT var i seg selv en viktig symbolsk handling. Vedtaket markerte at Nord-Norge nå ville bli en fullverdig del av kongeriket (Fulsås, 1993).

De ti effektene som jeg nå har vist til, vil selvsagt gjøre seg gjeldende i varierende grad, avhengig av institusjonenes størrelse og fagprofil, det omkringliggende nærings- og arbeidslivet, ressursene som står til rådighet, og hvor attraktive både universitetet og regionen oppfattes. Det kan være relativt få koblinger mellom institusjon og region, men et ordinært universitet med campusbasert undervisning og forskning vil aldri kunne operere helt adskilt fra samfunnet omkring. Universitetet vil sette sine spor. Det vil alltid være interaksjoner og avhengigheter begge veier. Jeg har så langt trukket fram ringvirkninger som de fleste vil oppfatte som positive, men fra en regional synsvinkel er det ikke gitt at universitetet bare blir oppfattet som en velsignelse. En universitetsetablering endrer de økonomiske, sosiale, politiske og kulturelle forholdene i en region, og dette kan bli mottatt på ulike måter.

\section{Potensielle ulemper for regionen}

De som tar høyere utdanning, tilegner seg kunnskaper, ferdigheter og vitnemål som kvalifiserer for nasjonale og internasjonale arbeidsmarkeder. Det er derfor ikke overraskende at flyttetilbøyeligheten stiger med utdanningsnivået (Stambøl, 1992, 1995). Folk med høyere utdanning er 
mer mobile enn de som har lavere utdanning. Enkelte har i lys av dette reist spørsmålet om hvilken verdi høyere utdanning har for distriktene. Edmund Edvardsen og Jens-Ivar Nergård, begge tidligere professorer ved UiT, har argumentert for at skolen utdanner ungdommen ut av distriktene (Bråthen, 1998; Edvardsen, 1981, 1989). Den formidler urbane verdier, holdninger og virkelighetsoppfatninger. Distriktsungdommen blir dermed fremmedgjort og løsrevet fra sin lokale kontekst. De blir gjort til «trekkfugler» i stedet for til «stamfugler». Ottar Brox har også helt siden tidlig på 1970-tallet, før de første studentene begynte ved Universitetet i Tromsø, advart mot et snarlig akademikeroverskudd. «Selv uten de kandidatkull som Tromsø om noen år kommer til å bidra med, er det sannsynlig at det snart går mot markedsdekning», hevdet han i 1972, og la til: «En stor del av de som kommer ut av Universitetet i Tromsø i 1980 må regne med å få store problemer med å få jobb» (Brox, 1972). I likhet med Caplan (2018) og forfattere før han (Berg, 1970) har Brox advart mot «overforbruk» av utdanning og argumentert for at læring skjer best gjennom praktisk arbeid og yrkeserfaring (Omvik, 2011).

Nå er sysselsettingsraten gjennomgående stigende med utdanningsnivået, så de som har høy utdanning, har større sjanser for å finne seg en jobb enn de som har lav utdanning. Men det er klart at dersom det er manglende samsvar mellom universitetets kandidatproduksjon og den regionale etterspørselen etter arbeidskraft, kan universitetet være med på å sluse ungdom ut av regionen. Utdanningene kan være populære, men om det ikke finnes relevante og konkurransedyktige jobber i regionen, vil den aktuelle landsdelen bli tappet for kompetanse. Dette kan bli forsterket hvis søkningen til universitetsstudier går sammen med en generell nedvurdering av håndverksfag, praktisk yrkesopplæring og ikke-akademiske kunnskapsformer, slik at svært få velger utdannings- og yrkesveier som det kanskje er et udekket behov for. Disse problemene vil særlig kunne gjøre seg gjeldende i distriktskommuner med et spinkelt arbeidsmarked og et privat næringsliv som tradisjonelt ikke har etterspurt kandidater med høyere utdanning. Tilstrømningen til utdanningssystemet kan i første omgang gjøre det lettere for de som blir igjen, og som ikke satser på videre skolegang, å konkurrere om de lokale jobbene. Men om det etter hvert blir mange ledige akademikere som kjemper om jobber som de 
formelt sett er overkvalifiserte for, kan dette bidra til å utestenge de som har minst utdanning.

For Nord-Norges del har nok den største kompetanseflukten alltid vært knyttet til at relativt mange av de unge har reist ut for å ta sin utdanning, og at bare et fåtall har vendt tilbake til landsdelen etterpå for å bo og arbeide der. UiTs kandidatundersøkelse for 2017 viste at universitetet samlet sett gir et kompetansetilskudd via flytting. 64 prosent av de uteksaminerte kandidatene kom fra Nord-Norge, basert på registrert hjemsted ved 16-årsalderen, mens 71 prosent av kandidatene fant seg jobb i landsdelen etterpå. Det har altså ikke vært en «brain drain», men en «brain gain». Det er imidlertid vesentlige forskjeller mellom studiene. Attraktive embetsstudier og andre tilbud som bare finnes ved et fåtall studiesteder, vil typisk ha studenter fra hele landet og sysselsette over hele landet. Ta for eksempel jus, der én av tre Tromsø-studenter finner jobb i Oslo etter endt utdanning. Det er jurister, sivilingeniører og samfunnsvitere som i størst grad forlater landsdelen etter endt studietid.

De høyere utdanningsinstitusjonene vil også vanligvis ha en sentraliserende effekt innad i regionen (Kunnskapsdepartementet, 2010; Stambøl, 2013). Mange velger å slå seg ned i nærheten av studiestedet. De kan ha funnet seg en partner som ennå studerer eller allerede er i jobb. De kan selv ha fătt en fot innenfor arbeidsmarkedet i løpet av studietiden. De kan ha skaffet seg bolig. Eller de har knyttet andre bånd til studiestedet. UiT har utvilsomt bidratt til en sentralisering, særlig til Tromsø-området. Ifølge den siste kandidatundersøkelsen kom 20 prosent av kandidatene fra Tromsø-regionen, mens 35 prosent endte opp der etterpå, hvilket utgjorde halvparten av alle kandidatene som jobbet i Nord-Norge. Tilsvarende tall ble funnet i den siste kandidatundersøkelsen for Universitetet i Nordland, som ble gjennomført i 2012 (Rambøll, 2013). Den viste at 68 prosent av kandidatene fant seg arbeid i Nordland, hvorav halvparten i Bodø. Konsentrasjonen av kandidater rundt studiestedene kan skape press både på arbeidsmarkedet og på boligmarkedet. De som står uten godt betalte jobber eller rike foreldre, stiller her svakest i konkurransen.

Da Universitetet i Tromsø ble etablert, oppsto det en kulturkollisjon i småbyen Tromsø. Med universitetet fulgte radikale studenter og demonstrasjonstog, og mange av byens innbyggere reagerte negativt på dette 
«fremmedelementet», som til og med gjorde sitt inntog i lokalpolitikken og i fagbevegelsen. Skismaet har nok nær sammenheng med den spesielle politiske konjunkturen på begynnelsen av 1970-tallet. Det er også i etableringsfasen at slike spenninger særlig vil kunne gjøre seg gjeldende. Men universitet og region kan være i utakt på flere måter. Mye av forskningen kan for eksempel fortone seg som virkelighetsfjern og lite relevant. Universitetet kan dermed bli stemplet som et elfenbeinstårn. I Tromsø bidro medisinerutdanningen og helseforskningen til at mange raskt så verdien av universitetsforskningen. Tromsøundersøkelsen, som er en omfattende kartlegging og analyse av befolkningens helsetilstand, og som har pågått regelmessig helt siden 1974, er et godt eksempel. Forskningsprosjektet har dannet utgangspunktet for et stort antall publikasjoner og doktorgrader. Samtidig har det ført til at en stor del av Tromsøs innbyggere er blitt tatt inn til en grundig helseundersøkelse med rådgivning og eventuell oppfølging. Men forskningen kan også være kontroversiell. Det gjelder for eksempel forskningen ved UiT omkring urfolk og minoritetsspørsmål, som har bidratt til at Stortinget nå har opprettet en sannhetskommisjon som skal granske fornorskingspolitikken overfor samer og kvener. Her står historiefortolkninger, identiteter og omfordeling av rettigheter på spill. Dette har skapt en opprivende mediedebatt i nord, der noen av de fremste forskningsmiljøene ved UiT blir angrepet og anklaget for å være ideologiske og partiske. Når universitetet utfordrer etablerte maktforhold og hierarkier i regionen, blir det ikke nødvendigvis omfavnet og betraktet som positivt i alle leirer.

\section{Regionens betydning for universitetet}

Jeg har til nå konsentrert meg om hvilken betydning et universitet har for den regionen der det er lokalisert. Hva med den omvendte sammenhengen? Hvilken betydning har regionen for universitetet? Igjen står vi overfor et sammensatt bilde.

\section{Potensielle gevinster for universitetet}

Regionen kan gi viktig drahjelp for universitetet på flere måter. For det første vil regionen ha betydning for rekrutteringen av både studenter og 
ansatte. Mens universitetet kan fungere som en magnet for regionen, vil en attraktiv region gi universitetet ekstra tiltrekningskraft. Her ser det ut til at de mest sentrale og folkerike regionene har et fortrinn. De har det mest varierte studietilbudet, arbeidstilbudet, servicetilbudet og kulturtilbudet. I hovedstadsregionen er det få av de unge som reiser ut for å studere, og Oslo mottar samtidig mange studiesøkende utenfra. De kommer fordi de vet at dette er et sted der de kan få ivaretatt et bredt spekter av interesser, og de kommer fordi andre har tenkt likedan før, slik at nykommerne gjerne har bekjente der. De samme faktorene teller for de som vurderer en jobb på universitetet, men her kan også andre forhold være mer utslagsgivende, slik som jobbmuligheter for ektefelle og skoleog fritidstilbud for barn.

Regioner som ikke er like sentrale, kan spille på andre fortrinn. Ved siden av å tilby mindre og mer oversiktlige studiemiljøer, kan de være attraktive i kraft av universitetets fysiske utforming, tilgangen på studenthybler og boliger, et lavere prisnivå, kortere reisetider, gode idrettsfasiliteter, allsidige friluftsmuligheter, spennende festivaler og mye annet. Ikke minst spiller vertskommunen en viktig rolle. Den kan gjøre en forskjell gjennom aktiv tilrettelegging og støtte til utbygging av studenthybler, barnehager, kollektivtransport og andre tjenester.

Regionen vil for det andre kunne ha betydning for utdanningene og deres kvalitet og yrkesrelevans. Det kan være en stor styrke for universitetet å ha regionale avtakere i offentlig og privat sektor som engasjerer seg i utformingen av studietilbudene, deltar i gjennomføringen av studieprogrammene og tilbyr praksisplasser og muligheter for skriving av prosjektoppgaver. Dette er med på å sikre at utdanningene er oppdaterte og etterspurte. Studierelatert kontakt med arbeidslivet øker sannsynligheten for at studentene vil finne en relevant jobb etter endt utdanning. Profesjonsfag, slik som sykepleierutdanning og lærerutdanning, har lenge vært kjennetegnet ved et tett samarbeid med yrkes- og praksisfeltene, men vi ser nå at tilsvarende samarbeid bygges ut i tilknytning til stadig flere studieprogrammer, og at det etableres nye traineeordninger. Et nært utdanningssamarbeid med eksterne aktører kan også resultere i mer etter- og videreutdanningsaktivitet og dermed økte oppdragsinntekter til universitetet. Alle universiteter og høgskoler er i dag pålagt å ha et 
råd for samarbeid med arbeidslivet (RSA). Verdien av dette rådet vil bli bestemt både av hva den enkelte institusjon gjør, og av hvordan det regionale nærings- og arbeidslivet velger å engasjerer seg.

For det tredje vil regionen kunne være en vesentlig ressurs når det gjelder forskningsvirksomheten. Noen ganger er det slik at temaer og problemstillinger nær sagt springer ut av regionen, i den forstand at de griper fatt i særskilte regionale utfordringer eller erfaringer. Det kan for eksempel handle om partisanene i Finnmark og deres innsats og skjebne under og etter andre verdenskrig. Eller det kan handle om årsakene til en regional overhyppighet av visse dødelige sykdommer, slik som hjerteog karsykdommer, som i sin tid var utgangspunktet for Tromsøundersøkelsen. Men selv om empirisk materiale og eksempler blir hentet fra regionen, skjer det vanligvis med sikte på å besvare spørsmål av mer allmenn karakter. UiT har for eksempel et senter for fremragende forskning (CAGE) som forsker på gasshydrater i Arktis, for dermed å forstå virkningene av metanutslipp på havmiljø og klimasystem generelt. God forskning prøver gjerne å se det allmenne i det særegne og det særegne i det allmenne. Følgelig kan et godt kjennskap til forholdene i egen region være et fortrinn og bidra til å gjøre forskningsmiljøet til en mer interessant samarbeidspartner for andre forskningsmiljøer internasjonalt.

Kunnskapsutviklingen skjer også i mange tilfeller i et samspill med bedrifter, offentlige myndigheter, frivillige organisasjoner og media. Det å ha mange relevante samarbeidspartnere i regionen er derfor gunstig for universitetet. De eksterne aktørene kan selv etterspørre forskning og tilføre ressurser, de kan være partnere i forskningssøknader, og de kan være med på å sette opp felles forskningssentre og dele på infrastruktur. Forskningsmiljøene i Tromsø har hatt et tett bedriftssamarbeid gjennom flere konsortier og sentre for forskningsbasert innovasjon, slik som Mabcent (Centre on Marine Bioactives and Drug Discovery) og CIRFA (Centre for Integrated Remote Sensing and Forecasting for Arctic Operations). Et annet godt eksempel er samarbeidsprosjektet mellom UiT og Finnfjord smelteverk om å redusere bedriftens CO2-utslipp gjennom dyrking av mikroalger og produksjon av fiskefôr. Ellers samarbeider UiT med alt fra lokalhistoriske foreninger og hagelag til Andøya 
rakettskytefelt og Kystvakten. Nærhet, tillit og felles ønsker om å utvikle regionen er i mange tilfeller en drivkraft i samarbeidet.

Et fjerde moment, som er mindre viktig enn de foregående, men som likevel er verdt å nevne, er at regionen kan ha betydning for universitetets evne til å fungere som en møteplass. For å kunne arrangere større konferanser og kongresser er det mange ting som må ordnes - påmelding, betaling, møtelokaler, overnatting, servering med mer. Et universitet har sjelden et profesjonelt apparat for å ivareta alle vertskapsfunksjonene. Hvis man derimot kan støtte seg på gode arrangører, hoteller og attraksjoner, er det lettere å kunne ta på seg større faglige arrangementer og sikre at alt går som smurt. Regionen er dermed med på å tilrettelegge for at universitetet kan bli en viktig møteplass.

For det femte kan regionen være en sterk politisk støttespiller for universitetet. Dette er blitt klart demonstrert gjennom bidragene til universitetsprosjektene i Stavanger, Agder, Nordland og Innlandet. Her har fylkeskommuner, kommuner, regionale energiverk og banker gått sammen om å kanalisere betydelige midler til institusjonene. Via Kompetanseog universitetsfondet for Innlandet, som ble opprettet i 2005, ble det for eksempel mobilisert 183 millioner kroner til de tre høgskolene i Gjøvik, Lillehammer og Hedmark. Alle satsingene på nye master- og doktorgrader ble finansiert med to tredeler fra fondet og en tredel fra høgskolene selv. Med dette klarte de tre høgskolene å bygge opp 17 mastergrader og fem doktorgrader fram til 2012. Støtte har også blitt gitt til forskningsprosjekter, senterdannelser og professorater, og det har vært avgitt politiske uttalelser og støtteerklæringer. Det er liten tvil om at den regionale innsatsen har vært avgjørende for alle de nyere universitetsprosjektene.

\section{Potensielle ulemper for universitetet}

Men om regionen kan gi viktig drahjelp for et universitet, kan den også fungere som en hemsko. En lite attraktiv region, med få kompetansekrevende jobbmuligheter, nedadgående ungdomskull og mange som reiser ut for å studere, kan slå negativt ut med hensyn til rekrutteringen og i neste omgang kvaliteten på både studenter og lærerkrefter. Utdanningene kan svekkes på grunn av manglende kontakt med nærings- og 
arbeidslivet i regionen eller fordi de sentrale avtakerne er lite opptatt av eksperimentering, læring og kunnskapsutvikling. På samme måte kan forskningen ha lite å hente fra regionen. Det kan skyldes at bedrifter og offentlige myndigheter ikke ser betydningen av forskning, eller at de mangler forutsetninger for å inngå i et nært forskningssamarbeid. Det kan også være at universitetet via det regionale samarbeidet blir drevet $\mathrm{i}$ retning av kortsiktige og anvendt orienterte forsknings- og utredningsoppdrag. I så fall kan en sterkere løsrivelse fra regionen være nødvendig for å heve forskningsambisjonene og -nivået. Sterk lokalpolitisk støtte kan også være tvetydig og skape problematiske bindinger, noe jeg vil komme tilbake til.

\section{Nye forutsetninger og perspektiver}

Spørsmålet som jeg nå vil reise, er om vi i dag ser utviklingstrekk som kan tenkes å modifisere det bildet som jeg hittil har tegnet. Hvordan blir forholdet mellom universitet og region i årene framover? Høyere utdanning har vært i støpeskjeen mer eller mindre permanent siden 1960-tallet. Den ene reformbølgen har avløst den andre. Særlig siden tusenårsskiftet har Bologna-prosessen og en skjerpet internasjonal konkurranse satt agendaen (Collett, 2004). Parallelt med dette har forestillingene om regionen endret seg. Sammenligner vi dagens situasjon med situasjonen ved inngangen til 1970-tallet, da Universitetet i Tromsø og de første distriktshøgskolene ble opprettet, er det flere markante endringer som har funnet sted. Jeg vil her særlig trekke fram seks omveltninger (se også Fulsås, 2018).

\section{Utdanningsvekst}

Den første er den generelle veksten innenfor høyere utdanning. Alle prognosene som i sin tid ble laget av Kleppe-komiteen, Ottosen-komiteen og Hernes-utvalget, viste seg å undervurdere den sterke utdanningsveksten som kom. Martin Trow drøftet tidlig på 1970-tallet de mange utfordringene knyttet til denne ekspansjonen (Trow, 1973). Han pekte på at veksten ville ha konsekvenser for alle sider ved høyere utdanning - finansiering, styring, opptak, undervisning, eksamensformer, forskning og institusjonenes rolle i samfunnet. Han så for seg en utvikling i tre faser - fra 
eliteutdanning via masseutdanning til universell utdanning - der utfordringene ville være ekstra store i overgangene mellom disse fasene. Den første overgangen kom da mer enn 15 prosent av årskullene tok høyere utdanning, den andre da andelen passerte 50 prosent. Da Trow skrev tidlig på 1970-tallet, var høyere utdanning fremdeles en eliteutdanning i Europa, mens USA hadde nådd masseutdanningens tidsalder. I dag er høyere utdanning i ferd med å bli universell i Europa så vel som i USA (OECD, 2018).

Ifølge Trow ville synet på høyere utdanning endre seg i løpet av de tre fasene. Så lenge adgangen er begrenset og forbeholdt et lite mindretall, vil høyere utdanning bli betraktet som et privilegium. Når høyere utdanning blir masseutdanning, vil utdanning bli betraktet som en rettighet for alle som tilfredsstiller de formelle kvalifikasjonskravene. Når høyere utdanning blir universell, vil det å ta slik utdanning nærmest bli obligatorisk. Trow pekte også på at det ville skje en utdanningsinflasjon i yrkeslivet, men han var langt mindre pessimistisk enn de som bare betraktet utdanning som et seleksjonsinstrument for arbeidsgivere (Arrow, 1973; Spence, 1973) eller et posisjonelt gode, som synker i verdi når flere skaffer seg det samme godet (Hirsch, 1976). Trow mente at etter hvert som stadig flere jobber fylles opp av kandidater med høyere utdanning, vil jobbene bli omdefinert og innholdet oppgradert. Koblingene mellom spesifikke utdanninger og yrker vil bli løsere, og de som ikke har høyere utdanning, vil oppleve større press på å skaffe seg formelle kvalifikasjoner for å kunne delta i konkurransen om jobbene.

I Norge har den omfattende utbyggingen og desentraliseringen av universitets- og høgskoletilbudet langt på vei gjort tilgangen til høyere utdanning til en rettighet. Alle deler av landet har nå fått ett eller flere universiteter, og institusjonene har nådd ut til en stor del av befolkningen. For eksempel har UiT ved utgangen av 2018 ti studiesteder (fra Mo i Rana i sør til Svalbard i nord), mens Nord universitet har ni studiesteder (fra Stjørdal i sør til Stokmarknes i nord). I denne prosessen er høyere utdanning blitt alminneliggjort. Statusen og glansen som tidligere fulgte med en universitetsetablering, har blitt redusert. Dagens studenter går ikke på universitetet; de går på skolen. Men dette er ikke ensbetydende med at høyere utdanning er blitt mindre viktig. Tvert imot er det snakk 
om en basal del av kunnskapssamfunnets infrastruktur (Arbo \& Selstad, 2004). Typisk for infrastrukturer er at de lett blir usynlige når de fungerer, men det merkes raskt når de svikter (Edwards, 2003; Star, 1999).

\section{Kvinnenes inntog}

Den andre store omveltningen er kvinnenes inntog i høyere utdanning. På 1960-tallet utgjorde kvinnene en liten minoritet blant studentene. I dag er 60 prosent av alle studentene her i landet kvinner. I Norge er både studier og arbeidsliv mer kjønnsdelt enn i mange andre land (Reisel \& Teigen, 2014), men det er grunn til å merke seg at kvinnene nå er i stort flertall i prestisjestudier som medisin og jus. At kvinnene i økende grad erobrer høyere utdanning, har reist en debatt om fagenes kunnskapsinnhold og om virkningene for studiemiljøet, for yrkesutøvelsen og for de som skal betjenes. Det er også bekymring for hva som vil skje med yrkenes status og lønnsnivå etter hvert som andelen kvinnelige yrkesutøvere stiger. Det diskuteres om det bør innføres mannskvoter eller andre incentiver for å bedre kjønnsbalansen i studier der mennene er i ferd med å forsvinne.

I et regionalt perspektiv er det særlig det store gapet i studietilbøyelighet mellom menn og kvinner som er interessant. Gapet er størst i flere av distriktsfylkene, med Finnmark på topp. Av alle fra Finnmark som tar høyere utdanning, er to av tre kvinner. En så stor kjønnsforskjell må få konsekvenser. De som tar høyere utdanning, vil være opptatt av å kunne bruke utdanningen sin etterpå når de søker seg en jobb. Ut fra prinsippet om at like barn leker best, kan det også forventes at utdanningsnivået påvirker partnervalget. I sum øker disse faktorene sannsynligheten for at kvinneunderskuddet i distriktene vil øke.

\section{Enhetlig institusjonssystem}

Den tredje sentrale endringen er utviklingen fra et todelt til et enhetlig institusjonssystem. Martin Trow (1973) så for seg at veksten innenfor høyere utdanning ville gi en stadig mer heterogen studentmasse. De store forskjellene med hensyn til bakgrunn, evner, ambisjoner og yrkesønsker ville kreve en sterkere differensiering av utdanningssystemet. Dette ble 
det også lagt opp til i Norge på 1960-tallet. Det ble foreslått at distriktshøgskolene primært skulle gi kortvarige, yrkesrettede utdanningstilbud. Men skillelinjene begynte raskt å bli mer diffuse. Distriktshøgskolene ble ikke paraplyer for all høyere utdanning i regionene. I stedet fikk de utvikle seg som små universitetskopier, og sammenslåingen av gamle og nye høgskoler gjennom høgskolereformen i 1994 styrket de akademiske aspirasjonene. Deretter fulgte en serie med omlegginger som gradvis visket ut skillet mellom høgskole og universitet - innføringen av felles stillingsstruktur, felles lov med krav om forskningsbasert utdanning, felles gradsstruktur pluss muligheten for opprykk fra høgskole til universitet etter nærmere fastsatte kriterier. I dag har vi i Norge 10 universiteter, fem vitenskapelige høgskoler, seks statlige høgskoler og diverse private og andre statlige høyere utdanningsinstitusjoner. Hvis denne utviklingen fortsetter, vil høgskolekategorien snart forsvinne. Alle de statlige høgskolene vil bli universiteter, enten gjennom fusjoner, egne akkrediteringssøknader eller ved at betegnelsen høgskole rett og slett faller bort.

Disse reformene har ført til at alle institusjonene nå konkurrerer på en arena der de fremste internasjonale forskningsuniversitetene danner forbildene og setter standardene (Musselin, 2018; Yudkevich, Altbach \& Rumbley, 2016). Selv om Kunnskapsdepartementet har videreført tankene om Norgesnettet og oppfordrer de høyere utdanningsinstitusjonene til å utvikle sin egen profil, blir de alle vurdert og belønnet etter de samme standardiserte kriteriene. Ingen av disse handler om institusjonenes bidrag til å høyne utdanningsnivået og fremme utvikling i egen region. Dette skaper store utfordringer, ikke minst for de profesjonsrettede høgskoleutdanningene og de nye universitetene med stort innslag av slike utdanninger (Slottemo, 2016). Det særnorske kravet til universitetsopprykk er at de må ha minst fem mastergrader og fire doktorgrader, og de møter strengere krav når det gjelder formell kompetanse, forskerutdanning, forskningsaktive fagmiljøer, internasjonalt samarbeid og publisering i godkjente kanaler. Lærerutdanningen har gått fra å være en treårig bachelorutdanning til å bli en femårig masterutdanning, noe som betyr at flere av de ansatte må ha førstestillingskompetanse, og det er kommet høyere karakterkrav for opptak til lærer- og sykepleierutdanningene. Med innføringen av «stykkprisfinansiering», der deler av den statlige 
bevilgningen er knyttet til studiepoengproduksjon og avlagte grader, har også studentenes etterspørsel blitt et viktigere premiss for hvilke studier institusjonene har råd til å tilby.

Fjerningen av det todelte systemet betyr i en viss forstand en likestilling av institusjonene. På den andre siden impliserer det en sterkere hierarkisering innenfor universitetskategorien (Fulsås, 2000). Idet høgskolene rykker opp og får universitetsstatus, utvikler det seg en klarere intern differensiering blant universitetene i form av status, prestisje og ressurstildeling (Slagstad, 2007). Etableringen av den såkalte U5-gruppen, der de eldste universitetene i Norge lager sine egne møteplasser på siden av Universitets- og høgskolerådet, kan ses som et uttrykk for dette. Det at profesjonsutdanningene blir dreid i mer akademisk retning, fører også til at fagskolene seiler opp som mulige alternative tilbydere av kortvarige, yrkesrettede utdanninger (NOU 2014: 14). Ifølge Per Nyborg, tidligere ekspedisjonssjef i Kultur- og vitenskapsdepartementet og generalsekretær i Universitets- og høgskolerådet, har «høyskolene (...) sviktet det tradisjonelle høyskoleoppdraget. Når høyskolene nå vil bli universiteter, vil vi trenge en ny faghøyskole som kan tilby høyere yrkesutdanning basert på erfaringskunnskap og faglig utviklingsarbeid» (Larsen, 2016). De nye universitetene kan dermed møte en tøffere konkurranse fra flere kanter.

\section{Digitaliseringen}

Den fjerde store omveltningen er knyttet til digitaliseringen, som i løpet av få tiår har omformet arbeid, dagligliv og mellommenneskelige relasjoner. Ved universitetene har digitaliseringen hatt dyptgripende konsekvenser for måten vi driver forskning og undervisning på. Det gjelder utstyr og instrumenter i vitenskapens tjeneste; innsamling, lagring og bruk av data; muligheter for beregning, modellering og simulering; samarbeid med kolleger, og publisering og formidling via sosiale medier. I undervisningen blir det tradisjonelle forelesningsformatet utfordret av online-kurs, videoer, digitale læringsplattformer og virtuelle klasserom. Studentene skal utvikle sine egne læringsporteføljer, og eksamen blir digital. Digitaliseringen har også endret de administrative systemene og service- og støttefunksjonene. Ikke minst er det skapt helt nye muligheter 
for å sammenstille informasjon og kvantifisere og rangere alle mulige prestasjoner, noe som har bidratt til å endre måten sektoren blir styrt på (Muller, 2018). Det skjer i dag en rask utvikling innenfor kunstig intelligens, sensorer, big data og tingenes internett, der ulike typer teknologier smelter sammen.

Digitale medier og Internett har skapt en mer grenseløs verden. Mens noen hevder at den nye teknologien opphever avstand, peker andre på at den skaper mer fragmenterte og komplekse rom (Malecki \& Moriset, 2007). Uansett åpnes det opp for at koblingene mellom universitet og region blir løsere. Den enkelte institusjon kan tilby utdanninger over hele landet, og alle regioner får potensielt tilgang til et stort antall utdanningsleverandører som kan bidra til livslang læring. Nå er distanseundervisning ikke noe nytt. Brevskoler og korrespondansekurs har eksistert i over hundre år. Flere av de mindre høgskolene har også søkt å øke eget studenttall ved å være aktive og arrangere nettbaserte kurs, ofte i samarbeid med NKI, NKS (nå Høyskolen Kristiania), Folkeuniversitetet, Studiesenteret.no og andre aktører. Det nye er de åpne nettkursene, såkalte MOOCs (Massive Open Online Courses), som nå tilbys i økende omfang internasjonalt. Ledende universiteter, slik som Stanford, Harvard og MIT, har engasjert seg, og det har på få år vokst fram mange store tilbydere: edX, Coursera, Udacity, Udemy, Khan Academy og FutureLearn. Wageningen University \& Research i Nederland startet for eksempel sitt første MOOC-kurs i desember 2014 og har etter fire år over en halv million registrerte kursdeltakere fra hele verden. Spørsmålet er om de åpne nettkursene vil komme på toppen av de eksisterende, campusbaserte studietilbudene, eller om de vil omforme og langt på vei fortrenge andre tilbud. De nye aktørene kan komme til å utfordre universitetene ikke bare når det gjelder deres undervisningstjenester, men også deres akkrediteringsmonopol (Arbo, 200o).

\section{Internasjonal mobilitet}

Den femte endringen er den økende vektleggingen av internasjonal mobilitet. Bologna-prosessen, som ble initiert i 1999 og i dag omfatter 48 stater og EU-kommisjonen, har tatt sikte på å skape et felles europeisk område for høyere utdanning, slik at det blir lettere å studere og arbeide på tvers av 
landegrensene. Grunntanken er at en utdanning anerkjent i ett land, automatisk skal bli anerkjent i et annet. For å gjøre utdanningene sammenlignbare og sikre kvalitet og nivå er de høyere utdanningene blitt organisert i tre sykluser (bachelorgrad, mastergrad og doktorgrad), det er laget beskrivelser av forventet læringsutbytte i form av kvalifikasjoner, det er etablert felles prinsipper for akkreditering og kvalitetssikring, og det er innført et system med konvertible kredittpunkter - kalt studiepoeng på norsk basert på antatt arbeidsinnsats målt i timer (European Credit Transfer and Accumulation System). I tillegg er det opprettet flere stipendprogrammer for å fremme mobilitet, slik som Erasmus+ og Nordplus. Norske studenter som reiser ut, kan dessuten få ekstra lån og stipend fra Lånekassen.

Gjennom Bologna-prosessen har Norge forpliktet seg til et mål om at 20 prosent av studentene skal ha et studieopphold i utlandet, og ambisjonen er å løfte denne andelen til 50 prosent. Enkelte institusjoner går også lenger, slik som NTNU, der ledelsen har signalisert at alle studenter i framtida må regne med å ha et utenlandsopphold bak seg for å kunne ta en universitetsgrad. Det diskuteres om kortvarige opphold og virtuell mobilitet skal telles med, men hovedbudskapet er at utenlandsopphold etter hvert skal bli normalen for alle studenter. Når utdanning mer og mer handler om bevegelighet, er dette nok en faktor som vil endre forholdet mellom universitet og region. Gode internasjonale samarbeidsavtaler og tilrettelagte utvekslingsordninger kan bli viktigere kriterier når studentene skal velge lærested. Flere utreisende og innreisende studenter kan gi nye impulser og bidra til å vitalisere studiestedene. Det samme gjelder utenlandske forskere og ph.d.-kandidater, som tilfører verdifull kompetanse. Fravær av studieavgifter og lønn under ph.d.-utdanningen har gjort Norge til et attraktivt land for mange utdanningssøkende. Men når utdanningene blir på engelsk, mange av de ansatte og studentene ikke snakker norsk, og de forblir svakt integrert i lokalsamfunnet, vil ringvirkningene av universitetet bli annerledes enn før.

\section{De mange regionene}

Den siste endringen som jeg vil trekke fram, er oppløsningen av regionen. Med det sikter jeg til at hele den territorielle referanserammen er 
blitt mer uklar og omstridt. Da Universitetet i Tromsø ble etablert, var det som det nordnorske universitetet. Det skulle tjene landsdelen, som strakte seg fra Bindal til Grense Jakobselv. Universitetet var selv en del av den kulturelle reisningen som gjorde Nord-Norge til en sentral identitetsregion (Brox, 1966; Drivenes, Hauan \& Wold, 1994a, 1994b; Heløe, 2016). Samtidig med at UiT ble etablert, ble det drevet en samordnet landsdelsplanlegging i regi av Landsdelskomiteen for Nord-Norge (NOU 1972: 33). Men fra midten av 1970-tallet ble planlegging, utbygging og andre samfunnstjenester hektet på de nye fylkeskommunene, og fylkesgrensene ble stadig viktigere. I høyere utdanning fikk vi regionale høgskolestyrer i hvert enkelt fylke. På 1980-tallet fulgte den samepolitiske mobiliseringen, som førte til etableringen av Sametinget i 1989, og siden har både Barentsregionen og nordområdene vært drevet fram som konkurrerende regionprosjekter i nord. Parallelt med dette har staten valgt å organisere sin regionale virksomhet etter høyst ulike inndelingsprinsipper, og den pågående regionreformen har igjen skapt nye grenser og grensekriger. Dette har multiplisert antallet regioner som til enhver tid kan gjøres relevant (Arbo, 2007a; Niemi, 1996; Røvik, 2011). Samtidig er den gamle distriktspolitikken, som representerte en statlig distriktsutbygging basert på en likhetsnorm, blitt avløst av en regionalpolitikk som sier at det er den enkelte region som må sørge for innovasjon og vekstkraft (Arbo, 2007b).

De høyere utdanningsinstitusjonene er en del av dette spillet. Kampen for et eget universitet i Bodø forsterket splittelsene i nord og ga næring til bykampen mellom Tromsø og Bodø. Med strukturreformen i universitets- og høgskolesektoren er det atter en gang tegnet nye regioner. Flertallet i Stjernø-utvalget (NOU 2008: 3) så for seg en politisk styrt gruppering av de høyere utdanningsinstitusjonene i landsdelsregioner med et etablert universitet i spissen. Slik gikk det ikke. Myndighetene stilte i $2014 \mathrm{krav}$ om fusjonering, men det ble opp til institusjonene å velge sine partnere. Dermed ble Nordland og Nord-Trøndelag koblet sammen via Nord universitet, som skulle prøve å finne sin plass mellom Universitetet i Tromsø og NTNU. NTNU fikk på sin side et fotfeste i Ålesund og på Gjøvik og har nettopp åpnet en avdeling for etter- og videreutdanning i Oslo.

Et viktig moment er at strukturreformen har gitt mange flercampusinstitusjoner. I sammenslåingsprosessene har vi sett et stort engasjement 
fra kommunestyrer, regionråd, fylkesting, lokale næringsforeninger og avisredaktører, som alle har hatt sterke meninger om organiseringen av de nye institusjonene og lokaliseringen av fakulteter og ledelsesfunksjoner. Da ledelsen ved Nord universitet foreslo å konsentrere fagmiljøene til to campuser (Bodø og Levanger), ble det full mobilisering på Helgeland og i Namdalen. Dette viser at høyere utdanning blir oppfattet som viktig. På den andre siden betyr det at universitetene ikke bare møter én region, men et virvar av motstridende lokalinteresser og pressgrupper. Det er etter hvert blitt veldig mye geografi. Fredrik Thue (2017) og Narve Fulsås (2018) har pekt på at utviklingen innenfor høyere utdanning har skapt en paradoksal situasjon: På nasjonalt plan har det skjedd en avpolitisering. Strategiske spørsmål er blitt overlatt til NOKUT som nøytralt ekspertorgan. På lokalt og regionalt nivå har det derimot skjedd en hyperpolitisering. Høyere utdanningspolitikk er mer enn noen gang blitt lokal- og regionalpolitikk.

\section{Navigering i vanskelig farvann}

Jeg startet med å drøfte samspillet mellom universitet og region fra et regionalt ståsted. Hvilken betydning har universitetet for regionen? Deretter prøvde jeg å se det fra et institusjonelt ståsted. Hvilken betydning har regionen for universitetet? Så har jeg rettet søkelyset mot noen sentrale endringsprosesser som setter samspillet i et nytt perspektiv. Gjennomgangen har vist at det gir liten mening å snakke om regionalt engasjement som en tredje oppgave for universitetene; som noe som kommer i tillegg til utdanning og forskning. Universitetene ivaretar mange roller. De er regionalt innvevd, og de vil alltid stå i et symbiotisk forhold til sine omgivelser. Både universitetene og deres omgivelser blir imidlertid stadig mer komplekse, og for å håndtere denne kompleksiteten må universitetene bygge inn en rekke ulike hensyn og krav i sin egen organisasjon og virksomhet. Avslutningsvis vil jeg derfor peke på noen av dilemmaene som dette reiser, særlig for de som skal lede institusjonene.

Det er blitt vanskeligere å være en liten institusjon innenfor dagens høyere utdanningssystem. Gjennom universitets- og høgskoleloven og hundrevis av forskrifter er universitetene og høgskolene underlagt krav 
og retningslinjer for opptak, studier, eksamen, klager, rammeplaner, studiekvalitet, akkreditering, delagasjon av myndighet og mye annet. Det gis også mange føringer og bestillinger gjennom tildelingsbrev og tilbakemeldinger fra etatsstyringsmøter. Dette innebærer at institusjonene må ha et stort antall systemer og rutiner på plass. De må blant annet lage langtidsplaner, virksomhetsplaner, årsbudsjett, beskrivelser av kvalitetssystemer, risiko- og sårbarhetsanalyser og ledelsessystemer for informasjonssikkerhet. Videre må de lage strategier og handlingsplaner for alt fra likestilling til internasjonalisering, og de er pålagt en omfattende rapporteringsvirksomhet. Dette krever ikke bare en profesjonell administrasjon, men en administrasjon som er stor nok til å ivareta alle oppgavene. I selve styringen av sektoren ligger det derfor et press i retning av sammenslåinger. Små institusjoner risikerer i dag å bli overbelastet.

Samtidig møter institusjonene motstridende forventninger. På den ene siden skal de ha robuste fagmiljøer av høy kvalitet. De skal være forskningsaktive, publisere internasjonalt, drive forskningsbasert undervisning og tilby attraktive fag- og læringsmiljøer. På den andre siden skal de være regionalt relevante og distriktsnære. I samfunnsoppdraget, særlig for de tidligere høgskolene, ligger det at de skal levere forskning og utdanne kandidater som regionen etterspør. Slike spenninger er det mange av. Utdanningene skal for eksempel ha høy faglige kvalitet, men det forventes også at institusjonene driver billig og effektiv masseutdanning. De skal stille høye krav til alle som vil inn. Samtidig skal de bidra til likhet og sosial inkludering. De skal kvalifisere for morgendagens ukjente arbeidsliv. Samtidig skal de sørge for at kandidatene får seg jobb her og nå. Alle institusjonene skal utvikle sin egen, distinkte profil. Samtidig er de underlagt standardiserte indikatorer som måler hver og en av dem på det samme. Universitetene forventes å opptre som strategiske aktører. Samtidig blir det understreket at prinsippene om forskningsfrihet og høy grad av faglig og institusjonell autonomi skal gjelde.

De spenningsfylte forventningene kunne tidligere bli ivaretatt av ulike institusjoner. Hernes-utvalget så for seg at høgskolene skulle ha hovedansvaret for profesjonsutdanningene og den regionale forskningen, 
mens universitetene skulle ha hovedansvaret for grunnforskningen og forskerutdanningene. I dag er alle de høyere utdanningsinstitusjonene i ferd med å bli universiteter. Det betyr at spenningene for en stor del må håndteres innenfor rammene av de fusjonerte institusjonene, som nå er blitt større, mer sammensatte og spredt på flere studiesteder. Her er noen bekymret for «akademisering», mens andre er bekymret for «høyskolifisering» eller «gymnasifisering». Det er dragkamper om ressurser mellom bachelor-, master- og ph.d.-utdanningene, og mellom ulike fagmiljøer og studiesteder. I denne situasjonen kan den regionale støtten vise seg å være et tveegget sverd. Den har i mange tilfeller vært avgjørende i universitetsbyggingen og etableringen av nye randsoneinstitusjoner, men den legger også restriksjoner på hva institusjonene kan gjøre.

Et mantra i dagens høyere utdanningspolitikk er «konsentrasjon for kvalitet» (Kunnskapsdepartementet, 2015). Det skal skapes sterke og konkurransedyktige fagmiljøer, noe som er institusjonenes eget ansvar - hvis ikke kommer NOKUT og truer med å trekke akkrediteringen tilbake. Følgelig må institusjonene kunne omrokere ressurser og eventuelt legge ned små og sårbare studiesteder. Men dette er problematisk siden campusstrukturen langt på vei er skapt gjennom tidligere stortingsvedtak. Under fusjonsprosessene kan det også være gitt diverse løfter og garantier. Så selv om universitets- og høgskolestyrene i prinsippet står fritt tilå treffe sine organisatoriske beslutninger, vil de i praksis ofte være bundet, og beslutningene kan lett bli blokkert. Dette er i ferd med å bli et ømt punkt ved flere av de sammenslåtte institusjonene, og det understreker hvilket minefelt de nå må navigere i. Konfliktene har hittil toppet seg rundt Nord universitet, der departementet i 2019 nærmest satte styret under administrasjon. De lokale og regionale interessentene mobiliserte mot universitetsledelsen og nedleggingsforslagene, men de protesterte også mot sentralpolitisk ansvarsfraskrivelse. Det ble vist til at universitetet var underfinansiert i forhold til kravene som ble stilt og de mange utdanningsstedene som institusjonen hadde, og det ble krevd at staten som eier måtte gripe inn. De regionale protestene kan derfor være tvetydige for universitetene. De kan svekke deres omdømme og legitimitet. Nord universitet ble på Nesna omdøpt til «Mord universitet». Samtidig 
kan protestene sanke politisk støtte i Stortinget og kanskje utløse statlige ekstrabevilgninger.

\section{Avslutning}

I forskningen om symbiotiske relasjoner mellom biologiske organismer blir det pekt på at organismene kan være mer eller mindre avhengige av hverandre for overlevelse. Samlivet kan være preget av mutualisme (det kommer begge til gode), kommensalisme (den ene oppnår fordeler uten at den andre blir berørt) eller parasittisme (den ene snylter på den andre, slik at den andre parten blir skadelidende). I relasjonen mellom universitet og region kan nok begge til en viss grad leve uavhengig av hverandre. De ressursene som universitetet trenger, kommer primært fra staten og andre overregionale kilder. Regionen kan på sin side ha begrenset nytte av det nærmeste universitetet. Men utviklingen har gått i retning av større gjensidig avhengighet. Det skyldes veksten i høyere utdanning, institusjonenes stadig bredere kontaktflate og den økte samfunnsmessige betydningen av vitenskapsbasert kunnskap og teknologi. Holder vi oss til den biologiske analogien, kan universitetet og regionen dermed inngå i et positivt samspill. De kan gjensidig styrke og berike hverandre. Men det kan også være slik at det fortrinnsvis er den ene parten som har fordeler, mens den andre forblir uberørt eller svekket. Alternativt kan både universitetet og regionen virke negativt på hverandre. De kan holde hverandre tilbake, stagnere og bli stadig mer marginaliserte.

Jeg har i dette kapitlet prøvd å kaste lys over disse prosessene og hva som er forutsetningene for det ene eller andre utfallet. Samtidig har jeg understreket at universitetene opererer på mange nivåer. Det er som formidlere, brobyggere og knutepunkter i omfattende kunnskapsnettverk som «mikrokosmoser av det globale og universelle» (Frank \& Meyer, 2007) - at de har sin sentrale verdi. Det er viktig å opprettholde desentraliserte utdanningstilbud og tilrettelegge for livslang læring, men en ensidig regional orientering vil bety at institusjonene blir provinsielle og uten faglig kvalitet. Her blir det også stadig mer uklart hva som egentlig menes med regionen. Mens universitetene eksploderer og sprenger grenser, ser det ut til at mange av regionene imploderer og blir stadig mer fragmenterte. 


\section{Referanser}

Arbo, P. (200o). Universitetene og høgskolene - kunnskapssamfunnets knutepunkter? I H. Gammelsæter (Red.), Innovasjonspolitikk, kunnskapsflyt og regional utvikling. Trondheim: Tapir Akademisk Forlag.

Arbo, P. (2007a). Den regionale fellesnevner. Plan, 39(2), 20-27.

Arbo, P. (2007b). Landsdelsplanlegging før og nå. Kart og Plan, 67(1), 16-26.

Arbo, P. (2011). Universitetet som regional utviklingsaktør. I S. Jentoft, J.-I. Nergård \& K. A. Røvik (Red.), Hvor går Nord-Norge? Tidsbilder fra en landsdel i forandring (s. 213-222). Stamsund: Orkana Akademisk.

Arbo, P. (2018). Universitetet som nyskapingsfabrikk. Ottar, 319, 14-21.

Arbo, P. \& Benneworth, P. (2007). Understanding the regional contribution of higher education institutions: A literature review, OECD Education Working Papers, No. 9. Paris: OECD Publishing. https://doi.org/10.1787/161208155312

Arbo, P. \& Selstad, T. (2004). Kunnskapssamfunnets institusjoner og transformasjoner. I P. Arbo \& H. Gammelsæter (Red.), Innovasjonspolitikkens scenografi: Nye perspektiver på noringsutvikling (s. 25-49). Trondheim: Tapir Akademisk Forlag.

Arrow, K. J. (1973). Higher education as a filter. Journal of Public Economics, 2(3), $193-316$.

Bender, T. (Red.) (1988). The university and the city: From medieval origins to the present. New York/Oxford: Oxford University Press.

Benneworth, P. (Red.) (2019). Universities and regional economic development: Engaging with the periphery. London/New York: Routledge.

Benneworth, P. \& Fitjar, R. D. (2019). Contextualizing the role of universities to regional development: Introduction to the special issue. Regional Studies, Regional Science, 6(1), 331-338.

Berg, I. (1970). Education and jobs: The great training robbery. New York: Praeger. Bertelsen, T. I. (1963). Hvor kommer lægene fra og hvor blir de av? Tidsskrift for Den norske loegeforening, 861-870.

Brox, O. (1966). Hva skjer i Nord-Norge? Oslo: Pax.

Brox, O. (1972). Undervisning og forskning i relasjon til økonomisk og sosial utvikling i Nord-Norge. Arbeidsdokument nr. 23, Landsdelskomiteen for NordNorge.

Bråthen, T. (1998). Utdanning tapper distriktene for ungdom. Nordlys, 21. februar 1998.

Caplan, B. (2018). The case against education: Why the education system is a waste of time and money. Princeton: Princeton University Press.

Collett, J. P. (1999). Historien om Universitetet i Oslo. Oslo: Universitetsforlaget.

Collett, J. P. (2004). Frihetens tunge bør. Nytt Norsk Tidsskrift, 2/2004, 182-193. 
Drivenes, E.-A., Hauan, M. A. \& Wold, H. A. (Red.) (1994a). Nordnorsk kulturhistorie 1: Det gjenstridige landet. Oslo: Gyldendal.

Drivenes, E.-A., Hauan, M. A. \& Wold, H. A. (Red.) (1994b). Nordnorsk kulturhistorie 2: Det mangfoldige folket. Oslo: Gyldendal.

Drucker, J. \& Goldstein, H. (2007). Assessing the regional economic development impacts of universities: A review of current approaches. International Regional Science Review, 30(1), 20-46.

Edvardsen, E. (1981). Skolen som en parentes i samfunnet. Norsk Pedagogisk Tidsskrift, nr. 7 .

Edvardsen, E. (1990). Fra streifdyr til standfugl? Identitetsdanning og rekruttering i distriktene. Rapport 2/1990, Avdeling for praktisk-pedagogisk utdanning. Tromsø: Universitetet i Tromsø.

Edwards, P. N. (2003). Infrastructure and modernity: Force, time and social organization in the history of sociotechnical systems. I T. J. Misa, P. Brey \& A. Feenberg (Red.), Modernity and technology (s. 185-226). Cambridge, MA: MIT Press.

Eide, K. (1995). OECD og norsk utdanningspolitikk: En studie av internasjonalt samspill. Oslo: Utredningsinstituttet for forskning og høyere utdanning.

Florax, R. (1992). The university: A regional booster? Economic impacts of academic knowledge infrastructure. Aldershot: Avebury.

Forland, A. \& Haaland, A. (1996). Universitetet i Bergens historie. Bind I. Universitetet i Bergen.

Frank, D. J. \& Meyer, J. W. (2007). University expansion and the knowledge society. Theory and Society, 36(4), 287-311.

Fulsås, N. (1993). Universitetet i Tromsø 25 år. Universitetet i Tromsø.

Fulsås, N. (2000). Frå binært til hierarkisk system i høgre utdanning? Historisk tidsskrift, 130, 385-396.

Fulsås, N. (2018). Universitetet, landsdelen og avviklinga av Nord-Noreg. Ottar, 319, 7-13.

Gythfeldt, K. \& Hagen, K. (2013). Hva betyr høgskolene for rekruttering av arbeidskraft til egne regioner? Søkelyset på arbeidslivet, 30(3), 235-250.

Heløe, L. A. (2016). «Nye folkevalgte regioner» - en dårlig løsning på distriktenes problemer. Nytt norsk tidsskrift, 33(3), 230-241.

Hirsch, F. (1976). Social limits to growth. Cambridge, MA: Harvard University Press.

Huggins, R. \& Johnston, A. (2009). The economic and innovation contribution of universities: A regional perspective. Environment and Planning C: Politics and Space, 27(6), 1088-1106.

Kantar TNS (2017). Kandidatundersøkelsen 2017. UiT Norges arktiske universitet, Høgskolen i Harstad og Høgskolen i Narvik. Tromsø: UiT Norges arktiske universitet. 
Koselleck, R. (1988). Vergangene Zukunft: Zur Semantik geschichtliche Zeiten. Berlin: Suhrkamp Verlag.

Kunnskapsdepartementet (2015). Konsentrasjon for kvalitet - Strukturreform i universitets- og høyskolesektoren. (Meld. St. 18 (2014-2015)). Oslo: Kunnskapsdepartementet.

Larsen, Ø. (2016). Per Nyborg: På tide med en faghøyskole? Intervju med Per Nyborg. Michael, 13(1), 67-72.

Malecki, E. J. \& Moriset, B. (2008). The digital economy: Business organization, production processes, and regional development. London/New York: Routledge.

Muller, J. Z. (2018). The tyranny of metrics. New Jersey: Princeton University Press.

Musselin, C. (2018). New forms of competition in higher education, Socio-Economic Review, 16(3), 657-683.

Niemi, E. (1996). Nord-Norge - én region eller regionenes region? I B. A. Berg \& E. Niemi (Red.), Energi, modernisering og byutvikling i Nord-Norge. Rapport fra det 29. nordnorske historieseminaret, Hammerfest 1.-3.10.2004 (s. 87-104). Tromsø: Institutt for historie, Universitetet i Tromsø.

Nilsson, J.-E. (Red.) (2006). The role of universities in regional innovation systems - a Nordic perspective. København: Copenhagen Business School Press.

NOU 1972: 33. (1972). Om landsdelsplan for Nord-Norge; Forslag til plan for utvikling av landsdelen. Oslo: Miljøverndepartementet.

NOU 2008: 3. (2008). Sett under ett - Ny struktur i høyere utdanning. Oslo: Kunnskapsdepartementet.

NOU 2014: 14. (2014). Fagskolen - et attraktivt utdanningsvalg. Oslo: Kunnskapsdepartementet.

OECD (2018). Education at a Glance 2018: OECD Indicators. Paris: OECD Publishing. https://doi.org/10.1787/eag-2018-en

Omvik, E. (2011). Advarer mot overutdanning. Intervju med Ottar Brox. Universitas, 7. september 2011. Hentet fra http://universitas.no/akademia/56409/ advarer-mot-overutdanning/

Pinheiro, R., Benneworth, P. \& Jones, G. A. (Red.) (2012). Universities and regional development: A critical assessment of tensions and contradictions. London/ $\mathrm{New}$ York: Routledge.

Rambøll (2013). Universitetet i Nordland kandidatundersøkelse 2012. Oslo: Rambøll Management Consulting.

Reisel, L. \& Teigen, M. (Red.) (2014). Kjønnsdeling og etniske skiller på arbeidsmarkedet. Oslo: Gyldendal Norsk Forlag.

Rutten, R., Boekema, F. \& Kuijpers, E. (Red.) (2003). Economic geography of higher education: Knowledge infrastructure and learning regions. Abingdon: Routledge. 
Ruud-komiteen (1965). Innstilling om Mulighetene for høgre undervisning og utvidet forskning i Tromsø, avgitt den 5. januar 1965 til Kirke- og undervisningsdepartementet.

Røberg, K. I. K. (2014). Høgskolenes betydning for regional rekruttering til næringsrettede profesjonsyrker. HiOA Rapport 2014 nr. 7. Oslo: Høgskolen i Oslo og Akershus.

Røvik, K. A. (2011). Exit Nord-Norge? Lange linjer i landsdelens utvikling. I S. Jentoft, J.-I. Nergård \& K. A. Røvik (Red.), Hvor går Nord-Norge? Tidsbilder fra en landsdel i forandring (s. 23-39). Stamsund: Orkana Akademisk.

Saxenian, A. (1996). Regional advantage: Culture and competition in Silicon Valley and Route 128. Harvard, MA: Harvard University Press.

Segal Quince Wicksteed (1985). The Cambridge phenomenon: The growth of high technology industry in a university town. Cambridge, UK: Segal Quince Wicksteed Ltd.

Slagstad, R. (2006). Kunnskapens hus. Oslo: Pax.

Slagstad, R. (2007). Høyskolen som kunnskapens hus. Arbeidsnotat nr. 01/2007, Senter for profesjonsstudier, Høgskolen i Oslo. Oslo: Høgskolen i Oslo.

Slottemo, H. G. (2016). Et HiNT av kunnskap. Ei historie om Høgskolen i NordTrøndelag, 1994-2016. Nytt Norsk Tidsskrift, 33(1-12), 34-44.

Spence, M. (1973). Job market signaling. The Quarterly Journal of Economics, 87(3), 355-374.

Stambøl, L. S. (1992). Flytting og utdanning 1986-1989. Rapporter 92/15. Oslo: Statistisk sentralbyrå.

Stambøl, L. S. (1995). Flytting og arbeidsstyrken. Rapporter 95/28. Oslo: Statistisk sentralbyrå.

Stambøl, L. S. (2011). Den regionale betydningen av universiteter og høgskoler. Vedleggsrapport til NOU 2011:3 Kompetansearbeidsplasser - drivkraft for vekst i hele landet. Oslo: Kommunal- og regionaldepartementet.

Stambøl, L. S. (2013). Studentvandringer. Rekruttering til studier og tilførsel av nye høyt utdannende i et geografisk perspektiv. Rapporter 6/2013. Oslo-Kongsvinger: Statistisk sentralbyrå.

Star, S. L. (1999). The ethnography of infrastructure. American Behavioral Scientist, 43(3), 377-391.

Sæther, B., Mønnesland, J., Onsager, K., Sørlie, K. \& Arbo, P. (200o). Høgskolenes regionale betydning. NIBR prosjektrapport 2000: 9. Oslo: Norsk institutt for byog regionforskning.

Tatsuno, S. (1986). The technopolis strategy: Japan, high technology, and the control of the twenty-first century. New York: Prentice Hall.

Thue, F. W. (2017). Høgskoler på randen av universitetsstatus - akademisk løft eller dyp-politisering? Nytt Norsk Tidsskrift, 34(3), 286-300. 
Trow, M. (1973). Problems in the transition from elite to mass higher education. Berkeley: Carnegie Commission on Higher Education.

Yudkevich, M., Altbach, P. G. \& Rumbley, L. E. (Red.) (2016). The global academic rankings game: Changing institutional policy, practice, and academic life. New York: Routledge.

Østerberg, D. (2015). Universitetet som sosial institusjon - en sosiologisk betraktning. Sosiologisk tidsskrift, 23(1-2), 96-108. 


\title{
KAPITTEL 5
}

\section{Forskningens regionale betydning}

\author{
Hans Christian Garmann Johnsen
}

Universitetet i Agder

\begin{abstract}
This chapter addresses the regional impact of research. The chapter presents, and partly develops, a framework for analysing how research in a region impacts the knowledge forms in the region. In order to do so, the chapter both presents a systemic approach to the impact of research-based knowledge, defines itself within a sociology of knowledge tradition and also, based on that, uses a model of a regional knowledge system as a framework for analysing the impact of different kinds of regionally related research. This model divides the regional knowledge system into areas characterised by either institutions, norms, attitudes or rules. The chapter used this model of the regional knowledge system to map 55 different research projects that have been conducted in the Agder region of Norway over the last 15 years. The 55 projects represent a wide range of topics and disciplines. Based on this mapping, the chapter argues that a) the research projects have a clear strategy for the particular knowledge area in the region they are targeting and uses relevant methodologies for this purpose, b) research-based knowledge is supportive, helpful and critical in relation to existing regional knowledge, and c) research-based knowledge addresses a large spectrum of knowledge forms in the region. The chapter does not discuss the impact of this knowledge with respect to social change. Furthermore, a limitation of the study, as well as a suggestion for further research, is that it does not analyse how social change might be a result of parallel changes within several knowledge forms in the region.
\end{abstract}

Keywords: regional knowledge system, knowledge forms, sociology of knowledge, research-based knowledge

\section{Introduksjon}

Begrepet kunnskapssamfunnet er lansert for å betegne hvordan samfunnet i økende grad baseres på og utnytter kunnskap, ikke minst forskningsbasert kunnskap. Forskningen sees som en viktig bidragsyter

Sitering av dette kapitlet: Johnsen, H. C. G. (2019). Forskningens regionale betydning. I J. P. Knudsen \& T. Lauvdal (Red.), Geografi, kunnskap, vitenskap. Den regionale UH-sektorens framvekst og betydning (s. 131-154). Oslo: Cappelen Damm Akademisk. https://doi.org/10.23865/noasp.73.ch5.

Lisens: CC BY 4.0 
til å produsere ny kunnskap. Men, hva skjer med denne kunnskapen? Hvordan er veien videre fra at en forsker har funnet et eller annet, til samfunnet anvender eller tar hensyn til denne nye kunnskapen? Hvordan er sammenhengen mellom ny forskningsbasert kunnskap og samfunnsmessig endring? Mer spesifikt, hva er betydningen av å ha et aktivt forskningsmiljø i en region? Hvordan påvirker det regionen? Dette er enkle kunnskapssosiologisk spørsmål som det er lett å stille, men vanskelig å svare på. Det er sannsynlig at sosial endring skjer som en parallell bevegelse av institusjoner, regler, holdninger og normer i samfunnet. Hvis vi således skal forstå effekten av forskning, altså i denne sammenhengen forskningens regionale betydning, må vi se på den samlede betydning den har på alle disse områdene.

Bidraget i dette kapitlet tar således utgangspunkt i diskusjonene om kunnskapssamfunnet, men diskusjonen her vil likevel i liten grad rette seg mot spørsmål som hvilken målbar effekt forskning har, eller om forskning har vært årsak til sosial endring eller vært en innovasjonsdriver på ulike områder. Rammen for denne drøftelsen tillater ikke det. Jeg vil begrense meg til å diskutere spørsmålet om hva slags påvirkning vitenskapelig kunnskap og forskning har på den generelle kunnskapen $\mathrm{i}$ samfunnet. Intensjonen er altså ikke å si noe om hva som skjer av faktiske samfunnsmessig endringer som følge av forskning. Intensjonen er å se på hvordan den forskningsbaserte kunnskapen adresserer ulike deler av det regionale kunnskapssystemet og forsøker å påvirke dette.

I det følgende skal jeg anlegge et kunnskapssosiologisk perspektiv på spørsmålet om hvilken rolle forskningen kan spille i en region. Jeg skal gjøre to ting. Først skal jeg presentere og delvis utvikle en modell for hvordan forskningsbasert kunnskap påvirker et regionalt kunnskapssystem, dernest skal jeg presentere noen funn fra empiriske arbeider gjort $\mathrm{i}$ Agder-regionen over et tiår. Jeg skal argumentere for følgende: Forskningens regionale roller og betydning er langt mer kompleks enn det de to mest refererte modellene, den lineære modellen og interaksjonsmodellen, ser ut til å anta. Spør vi hva betydningen av forskning er, vil svaret være at forskning på sitt beste bidrar til styrking av samfunnets kunnskap, men kan også bidra til å fremme interesser, maktposisjoner eller simpelthen gi feil kunnskap om ting. Det er i kraft av sitt mangfold at forskningen med 
sin innsikt kan bidra til en bred samfunnsdebatt og en opplyst allmenhet, som igjen er nøkkelen til å utvikle et kunnskapssamfunn.

For å underbygge argumentet over skal jeg i dette kapitlet vise, med basis i empiri fra Agder, hvordan anvendt forskning foregår i relasjon til Agderregionen, og hvordan denne forskningen påvirker kunnskapsdannelsen i regionen. For å kunne gjøre dette skal jeg referere og delvis utvikle en modell for kunnskapsutvikling i en region. Gjennom å koble empirien til modellen skal jeg forsøke å tegne at bilde av mangfoldet av kunnskapsformer og forskningstilnærminger som utspiller seg i regionen. Ut fra dette argumenteres det i dette kapitlet for at et kunnskapssosiologisk perspektiv på forskningen er en fruktbar tilnærming til å forstå forskningens regionale betydning.

\section{Teoretisk bakteppe: Tre modeller}

Jeg skal kort forsøke å posisjonere argumentet i dette kapitlet innenfor det feltet som handler både om hvordan kunnskap utvikler seg i samfunnet, og om forskningens sosiale betydning. Jeg skal presentere tre modeller og argumentere for hvorfor jeg legger til grunn en av disse modellene.

Man kan på den ene siden tenke seg en lineoer modell: Kunnskap starter som forskning, gjerne i form av grunnforskning som kommer fram med helt ny kunnskap. Denne forskningen er så gjenstand for mer anvendt forskning. Innsikten fra grunnforskningen føres over på et konkret, anvendbart felt. Et eksempel på dette kan være kvantefysikk, som er brukt til å lage kvantedatamaskiner, eller forskningen som oppdaget gener og har resultert i anvendelse av genteknologi innenfor kreftforskning. Fra den anvendte forskningen blir kunnskapen kanskje plukket opp av en bedrift som ser kommersielle muligheter i å utnytte den. I eksemplene over kan det være å produsere og selge kvantedatamaskiner eller kreftmedisiner. På denne måten kommer det nye produkter og tjenester i samfunnet som antas å gi økt velferd.

Denne lineære kunnskapsforståelsen kan vi føre tilbake i tid. En sentral eksponent for den var den franske sosiologen August Comte (Comte, 1988). Comte argumenterte allerede på midten av 18oo-tallet for viktigheten av forskning, nettopp fordi den inngår i en slik lineær 
fornyelsesprosess i samfunnet. Argumentet er gjentatt mange ganger, blant annet i forskningspolitiske sammenhenger. I Meld. St. 4 (2018-2019) Langtidsplan for forskning og høyere utdanning 2019-2028 skriver regjeringen innledningsvis blant annet:

Forskning og høyere utdanning står sentralt i utviklingen av et bærekraftig samfunn, der kunnskap er nøkkelen til nye, grønne og lønnsomme arbeidsplasser og en bedre og mer effektiv offentlig sektor. Den teknologiske utviklingen, med digitalisering som et gjennomgripende element, gir store muligheter, men byr også på utfordringer blant annet med hensyn til personvern og samfunnssikkerhet. Ulikhetene i samfunnet øker, og motsetninger polariseres. Samtidig står vi overfor store utfordringer når det gjelder klima og miljø, som bare kan møtes i samarbeid med andre land. Dette danner rammen for regjeringens langtidsplan for forskning og høyere utdanning. De overordnede målene for planen er å styrke Norges konkurransekraft og innovasjonsevne, møte store samfunnsutfordringer og utvikle fagmiljøer av fremragende kvalitet. (Kunnskapsdepartement, 2018)

Denne lineære tenkningen støter likevel på noen utfordringer: Er det nå slik at all forskning inngår i slike enkle lineære prosesser? Er det slik at all forskning representerer ny kunnskap som så genererer en ny lineær prosess? Og er det slik at all ny forskning leder fram til økt velferd, eller et bærekraftig samfunn, slik det er formulert over?

Det er nokså selvsagt at svaret på disse spørsmålene er nei. For det første, det meste av det som utføres av forskning i dag, er ikke grunnforskning, men nettopp anvendt forskning i ulike former. Startpunktet er ikke nødvendigvis at forskningen gir ny kunnskap. Startpunktet er i like stor grad utfordringer i samfunnet eller i bedrifter. Videre er det slik at forskning både kan være kritisk, den kan være sektoriell og den kan være normativ.

Dette er noen av årsakene til at det er lansert en alternativ modell, en interaktiv modell. Det er ulike navn på denne modellen. Et viktig bidrag til forståelse av den interaktive modellen kom fra forskerne Gibbons, Limoges, Nowotny, Schwartzman, Scott og Trow, som i 1994 lanserte begrepet the new production of knowledge (Gibbons et al., 1994). Dette arbeidet har generert en stor litteratur om universitetenes tredje rolle (Etzkowitz \& Leydesdorff, 200o) og såkalt co-generation of knowledge 
(Levin \& Greenwood, 2001). Denne litteraturen har igjen generert mer case-baserte studier av samskaping av kunnskap mellom universitet og region, eksempelvis Karlsen, Larrea, Wilson og Aranguren (2012). Det er på basis av og inspirert av denne litteraturen at Universitetet i Agder nylig definerte en ny strategi som heter samskaping av kunnskap. Denne strategien er altså et ekko av denne interaktive tenkningen.

Men den interaktive modellen støter også på noen utfordringer. Den forutsetter på sett og vis at det er et relasjonsforhold mellom forskeren og aktører i praksisfeltet, og at disse er bevisste på å løse oppgaver sammen. Det forutsetter også at kunnskapen som skapes, har en klar adresse. Det er således en modell som ikke er egnet til å analysere virkningen av forskningsbasert kunnskap på et mer systemisk nivå, det man kunne kalle den indirekte virkningen av kunnskap. Eksempelvis kommer dette klart fram i bærekraftdebatten; forskningen kan for eksempel bidra til å effektivisere oljeproduksjonen, men denne forskningen vil ikke uten videre kunne ta stilling til om fortsatt oljeproduksjon er ønskelig. Hvis målsettingen er, slik regjeringen skriver over, et bærekraftig samfunn, vil teknologisk utvikling innenfor oljeutvinning bidra til eller undergrave en slik målsetning? Mer generelt: Vil forskning som bidrar til nye produkter og bedre konkurranseevne for bedrifter, samtidig bidra til økt forbruk i verden eller økt bruk av ressurser, eller vil det øke bærekraft? Vil forskning på gener løse problemer for mennesker eller skape nye? Slike spørsmål er det vanskelig å svare på.

Jeg vil argumentere for at forskningens mer systemiske og kritiske rolle ikke er særlig godt ivaretatt i de to nevnte modellene. Den lineære modellen ser ikke uten videre helhetsbildet i forskningen, og den interaktive modellen er ikke uten videre egnet til å adressere forskningen i kritisk forstand. Derfor er det relevant å snakke om en tredje modell; den kunnskapssosiologiske modellen. I den kunnskapssosiologiske modellen kommer effekten av forskning fram i form av den måten den påvirker meningsstrukturen i samfunnet på. Forskning foregår på ulike måter, og forskningsprosessene organiseres på ulike måter like mye som forskningsresultatene tolkes og brukes på ulike måter. Hvordan kan vi fange inn dette mangfoldet? I det følgene skal jeg forsøke å forklare hva en kunnskapssosiologisk tilnærming innebærer. 


\section{Forskning i et kunnskapssosiologisk perspektiv}

Kunnskapssosiologen har sin bakgrunn i den klassiske sosiologien fra 18oo-tallet, utviklet av sosiologer som Emil Durkheim og Max Weber. Et hovedpoeng i deres analyse er den økte differensieringen i samfunnet (Weber, 1947; Durkheim, 200o). Felles er også synet på vitenskapen som en viktig driver i utviklingen av samfunnet. Rasjonalisering av det sosiale, vil noen si, er nettopp kjennetegnet på det moderne samfunn. Selve begrepet kunnskapssosiologi har sin opprinnelse tidlig på 190o-tallet, utviklet av Karl Mannheim, Max Scheler og Alfred Schütz (Mannheim,1979; Schütz, 1972; Scheler,1973). Argumentet deres er at kunnskap er forankret i sosiale strukturer og utvikles innenfor en livsverden. Kunnskap er forskjellig fra informasjon eller fakta i den forstand at noe blir kunnskap når det blir forstått, det vil si når det gir mening. Kunnskap er altså knyttet til fortolkning og til meningsstrukturer i samfunnet (Fuller, 2002).

Sosiologen Robert Merton regnes som pioneren i å anvende kunnskapssosiologi på vitenskap i form av vitenskapssosiologi (Merton, 1945). Merton har gitt viktige bidrag til å analysere fremveksten av vitenskapen som en strukturert prosess i samfunnet. Det har avstedkommet to perspektiver; et internt perspektiv på vitenskapens organisering og et eksternt perspektiv på vitenskapen i forhold til samfunnet rundt. Denne sosiologiske tradisjonen fikk en oppblomstring etter andre verdenskrig som følge av diskusjoner innenfor vitenskapsteori. Thomas Kuhn og Paul Feyerabend var sterke talsmenn for å sette søkelyset på hvordan forskere arbeider, og hva slags sosiale strukturer de inngår i (Kuhn, 1970; Feyerabend, 2010). Gjennom post-positivismen kan man si at vitenskapssosiologien blir en del av vitenskapsfilosofien. Både det interne og det eksterne perspektivet, hvordan vitenskapen organiseres, og hvordan den inngår i sosiale strukturer, tas videre inn i kunnskapssosiologien.

Karin Knorr-Cetinas arbeid omkring vitenskapen som epistemiske kulturer er viktig innenfor denne tradisjonen (Knorr-Cetina, 1999). Epistemiske kulturer er definert som forståelseshorisonter som deles av forskere innenfor et felt. En sentral tenker innenfor den eksterne sosiologiske analysen av vitenskapen er Fritz Machlup. Machlup startet et stort arbeid om produksjon og distribusjon av kunnskap fra 1950-tallet, og begynte med å lage empiriske kategorier for måling av effekten av 136 
kunnskap (Machlup, 1984). Et mer populærvitenskapelig arbeid basert på Machlup ble til Daniel Bells bestselger fra 1973 om det post-industrielle samfunn (Bell, 1973). Bell knytter veksten i satsing på universiteter og forskning, økning i antall studenter og i kunnskapsintensitet i produksjonen, til økonomisk og sosial utvikling, og han populariserer begrepet kunnskapssamfunnet (Stehr, 1994; Stehr \& Meja, 2005).

Disse korte glimtene fra kunnskapssosiologien utgjør noe av bakteppet for den diskusjonen vi får på 1990-tallet, og som ble referert over, om en mer aktiv kobling mellom akademia og samfunn. I denne diskusjonen ble også regionalisering en dimensjon. Eksempelvis, Richard Florida lanserte begrepet «lærende region» i 1995 (Florida, 1995) og innenfor EU ble man etter hvert mer oppmerksom på regionen som en økonomisk enhet (Rodrigues, 2002).

Det arbeidet jeg selv har deltatt i, og som har bidratt til empirien i dette kapitlet, er inspiriet av de perspektivene som er referert over. For eksempel gjorde vi sammen med kolleger en kartlegging av ulike forskningsmiljøer ved Universitetet i Agder (Pinheiro, Normann \& Johnsen, 2016). To forhold kom fram av de analysene vi gjorde, som er relevante for argumentet her: For det første registrerte vi klare strukturelle ulikheter mellom de ulike forskningsmiljøene. I så måte indikerer det relevansen av Knorr-Cetinas idé om epistemiske kulturer. For det andre registrerte vi at fagmiljøene ved et nytt universitet som Universitetet i Agder i stor grad imiterte de strukturene man har på tilsvarende fagmiljøer ved etablerte universiteter. Begge deler peker i retning av en institusjonalisering av forskning. Begge observasjonene underbygger således at forskninger inngår i, og skjer i innenfor, sosiale strukturer som påvirker meningsdannelse og forståelse. Min vurdering er at dette underbygger relevansen av det kunnskapssosiologiske perspektivet.

\section{Kunnskap i en region}

For å kunne si noe om hvordan ny kunnskap påvirker etablert kunnskap i en region, og dermed eventuelt bidrar til kunnskapsutvikling, er den nødvendig å skissere hva som forstås med kunnskap i en region. Dette var bakgrunnen for at jeg, sammen med kolleger, i boken Applied Social 
Science Research in a Regional Knowledge System (Johnsen et al., 2016) definerte noe vi kalte en modell for et regionalt kunnskapssystem. Vi kunne ha brukt ordet diskurs, men kom til at kunnskapssystem var et mer presist og konkret begrep, selv om ordet system kunne oppfattes veldig mekanisk. I den nevnte boken er det teoretiske grunnlaget for dette nærmere redegjort for. Modellen ble også videreutviklet i boken Coping with the Future (Johnsen et al., 2018). I det følgende skal jeg begrunne modellen og gjøre noen ytterligere presiseringer.

Utgangspunktet for den analysen som gjøres her, er at kunnskap er en sosial konstruksjon som skapes i sosiale prosesser der det foreligger ulike normer og validitetskrav. Videre er utgangspunktet det vi kan kalle «den kommunikative vending», forstått som at det er i form av ordsetting og språk at kunnskapen formes (Habermas, 1981, 2018). Dette er et epistemologisk utgangspunkt som innebærer at vi ser på kunnskapsprosessene ut fra et kunnskapssosiologisk perspektiv. En tenker som kommer tett på dette perspektivet, er den tyske sosiologen Jürgen Habermas, men vi har også en norsk tilnærming til dette gjennom arbeidene til arbeidslivssosiologen Bjørn Gustavsen (Toulmin \& Gustavsen, 1996). Begge har arbeidet for en samfunnsforskning som bidrar til økt kommunikativ rasjonalitet.

Jeg understreker sterkt at disse referansene kun er et utgangspunkt. Den måten jeg under vil definere et kunnskapssystem på, er en videreutvikling av disse prinsippene til anvendelse i en mer avgrenset kontekst, slik som en region. I hvilken grad en region virkelig er avgrenset kunnskapsmessig, vil være et empirisk spørsmål. Selvsagt vil mange temaer ikke ha regionen som grense. Likevel ser vi, med erfaring fra egen region (Agder), at visse spørsmål og oppfatninger sirkulerer her samtidig som de er ganske fremmede for andre. Det er grunn til at likestilling og religion er et viktigere tema på Agder enn på Østlandet. På samme måte er det en grunn til at ulvespørsmålet engasjerer mer på Østlandet enn på Vestlandet, og at folk i nord er mer opptatt av Barentsregionen enn folk i sør. Det er således rent intuitivt sannsynlig at det danner seg egne «diskurser» $\mathrm{i}$ regioner.

Også fra andre datakilder vet vi at det utvikler seg ulike forståelser i ulike regioner. Eksempelvis viser erfaringer med landsdekkende statlige foretak som NAV (Breit, Fossestøl, Pedersen, \& Thorbjørnsrud, 2017) 
og også fra de ulike regionale helseforetakene at ulike regioner har ulike praksiser (se Riksrevisjonen, Dokument 3:2 2017-2018). Ofte er nettopp argumentet for å desentralisere beslutninger at det er ulike regionale og lokale forhold og hensyn som bare de som er i regionen, forstår i tilstrekkelig grad. Hvis det ikke var slik, ville regionalisering mer generelt ikke gi mye mening. Jeg legger således til grunn at det i en region dannes kunnskap. For likeledes å koble dette til den case-regionen jeg refererer til, Agder, så kan det henvises til at Universitetet i Agder i sin strategi både har fremhevet sin regionale betydning og har, som nevnt, satt samskaping av kunnskap høyt på dagsorden. Så, hvordan samskapes kunnskap, eller for å vinkle det mot det spørsmålet som dette kapitlet forsøker å besvare: Hvilken rolle spiller forskningsbasert kunnskap i kunnskapsdannelsen i det regionale kunnskapssystemet på Agder?

\section{Kunnskapens former}

Før vi kan svare på dette, må vi tilbake til spørsmålet: Hva er et regionalt kunnskapssystem? Mer grunnleggende enn dette er spørsmålet: Hva er kunnskap? I den sosiologiske litteraturen blir dette spørsmålet ofte liggende ubesvart, og man foretrekker å snakke om hvilke former kunnskapen kommer i, og hvilke områder kunnskapen berører. Til det første, så skilles det ofte mellom det som er eksplisitt kunnskap, og det som er mer implisitt eller taus kunnskap. På den ene side har vi en konkret ting vi vet noe om, og som vi vet at vi vet. For eksempel kan vi vite hvor mange uføre det er på Agder i henhold til registrering i NAV-systemet, og ut fra SSB-data om den formelle kompetansen på Ager er lavere enn på Østlandet eller ikke.

Men kunnskap kan også være innbakt i normer og kutymer. Eksempelvis er manglende yrkesdeltakelse for kvinner på Agder blitt forklart med kultur. Spør du den enkelte kvinne om de valg hun gjør, så vil hun sannsynligvis si at ut fra hennes situasjon og samlede vurdering velger hun slik og slik. For henne er det rasjonelle valg, basert på eksplisitt, individuell kunnskap. Vi må generelt anta at kvinner på Agder som er hjemmeværende, anser dette som sitt eget valg. En sosiolog vil likevel kunne si at når det i et geografisk område er tydelige forskjell på i hvilken grad 
kvinner velger å være hjemmeværende med barn (for å ta det som eksempel) sammenlignet med andre områder, så tyder det på strukturelle årsaker eller effekten av kollektive normer; altså kollektiv, implisitt kunnskap.

Eksplisitt kunnskap kan både være kollektive forestillinger og personlig viten, men de to trenger ikke være identiske. Eksempelvis: Selv om mange forskere mener at evolusjonsteorien er riktig, er det ikke gitt at alle mennesker deler denne oppfatningen. Det er heller ikke gitt at folk handler ut fra eksplisitt kunnskap. Det fleste vet mye om sunt kosthold, likevel er det ikke alle som spiser sunt. Likeledes kan implisitt kunnskap både være personlige anliggender og erfaringer samtidig som det kan være kollektive normer og adferdsmønstre. De to trenger ikke være identiske. Vi kan være enig i en norm i betydningen at vi anerkjenner det som en gjeldende norm, uten at vi alltid følger den i vårt personlige liv. Våre personlige normer eller implisitte måter å gjøre ting på kan være både bedre og dårligere enn «den generelle normen».

Som vi skal se under, adresserer forskningsbasert kunnskap alle disse kunnskapsformene. Noen forskere ønsker å bidra med eksplisitt kunnskap om det som foregår, andre ønsker å adressere holdninger, normer, verdier og oppfatninger folk har. Noe kunnskap retter seg direkte til individer og deres eksplisitte forståelse av ting, annen kunnskap inngår i større grad som del av en kollektiv diskurs. I og med at disse kunnskapsformene er løst koblet til hverandre, er det ikke uten videre gitt at endring $\mathrm{i}$ en av kunnskapsformene har avgjørende betydning for endring $\mathrm{i}$ kunnskapssystemet. Dette underbygger argumentet om at vi må se på de samlede systemiske virkningene av den forskningsbaserte kunnskapen for å forstå dens betydning for samfunnet.

Så hvordan er det ny kunnskap påvirker et kunnskapssystem? Hvis vi igjen lener oss til Habermas, så definerer han noen grunnleggende diskurser som regulerer vår legitimitetsforståelse (Habermas, 2018). Det som skiller dem, er at de har ulikt legitimitetskrav. Hovedskillet går mellom tre diskurser: den moralske, den etisk og den pragmatiske diskursen. Den moralske diskursen er knyttet til vår livsverden, og legitimitetskravet knytter seg til autentisitet. Når vi agerer i livsverden, er det vår opplevelse og refleksjon i nær dialog med enkeltmennesker som utgjør diskursens ramme. Troverdighet, og dermed legitimitet, oppstår idet man tolker 
intensjoner og motiver. Ting som er sagt og gjort i god mening, står sterkere enn ting man betviler troverdigheten til. Det betyr også at forskningsbasert kunnskap har en utfordring med å «trenge inn i» livsverden.

Dette siste poenget var et av de viktigste argumentene for det arbeidet Bjørn Gustavsen initierte med tanke på en aksjonsforskningstilnærming til endring på arbeidsplassen. Gustavsen ønsket å fornye norsk arbeidslivsforskning gjennom dialogiske utviklingsprosesser. På den måten ønsket han å skape utvikling nedenfra ved at den var forankret i et personlig engasjement hos den enkelt (Toulmin \& Gustavsen, 1996). I disse prosessene er forskerens rolle å fasilitere dialogen og derigjennom bidra til at deltakerne selv utvikler nye forståelser av de temaene man diskuterer. Argumentet for dette er både at dette innebærer en mer demokratisk forskerrolle, og samtidig at denne forskningen potensielt når fram til deltakerne, skape ny kunnskap og fører til endring.

Den etiske diskursen knytter seg til normene som regulerer vår sosiale omgang. Dette er felles normer som utvikler seg i sosiale miljøer, både på et mer overordnet nivå og i det vi kunne kalle subgrupper. Legitimitetsgrunnlaget her er ofte aksept og etterlevelse, men også slik at normer begrunnes med referanse til andre, mer overordnede normer. Muligheten for å endre et normsystem ligger i å få kollektiv aksept for slike endringer. Forskning kan ofte ha som mål å påpeke uheldige sider ved normer og mønstre. Det betyr ikke uten videre at disse endrer seg. Kosthold kan kanskje tjene som illustrasjon, fordi kostholdseksperter til stadighet er ute i media og sier at vi bør endre kostholdet slik og slik (noe som tyder på at det ikke etterleves).

Den pragmatiske diskursen knytter ser til materielle forhold. Dette kan handle om makt og posisjoner, om hvem som tar avgjørelser, og hvordan fordeling av goder er. Her er ofte referansen produktivitet, rettferdighet eller effektivitet. I det liberale demokratiet vi lever i, har det blitt etablert en balanse mellom politisk makt og markedets makt, mellom stat og det offentlige på den ene siden, og den enkelte på den andre, for å neve noe. Ofte omtaler vi vårt samfunnssystem som den norske modellen, og den fremstilles gjerne som en gunstig og legitim modell. Det er ikke mulig å forklare nøyaktig hvorfor vi har dagens konfigurasjon av institusjoner, og hvorfor den har relativt bred støtte. Vi ser fra andre land at 
deres «modeller» utfordres. Legitimiteten forutsetter at modellen anses som akseptabel og har støtte i befolkningen. Forskningen kan gå inn på enkeltdeler av modellen og påpeke skjevheter, feil eller urettferdigheter. Modellen er ikke så rigid at den ikke kan justeres. Den er i kontinuerlig endring fordi samfunnssituasjonen endrer seg. Her er det et stort rom for deltakelse fra forskningen.

Habermas har i sine senere arbeider i økende grad påpekt også det juridiske og rettslige systemet som en separat diskurs. Hans argument er at den pragmatiske diskursen i stor grad har sin legitimitet knyttet til den rettslige diskursen. Likeledes er argumentet at mens den pragmatiske diskursen har sitt legitimitetsgrunnlag i en form for aksept, er ikke dette et tilfredsstillende grunnlag for å ha en rettsstat. En liberal og demokratisk rettsstat må i tillegg ha en referanse til abstrakte, rettslige prinsipper for likeverd og likbehandling, samt rettferdige prinsipper for transaksjoner og relasjoner i samfunnet. Selv om noen av disse abstrakte prinsippene er universelt gyldige, trenger vi en kontinuerlig diskusjon om «rules of the game».

Kommunikativ rasjonalitet oppnår man når man kombinerer de fire diskursene, det vil si at man har en forståelse av betydningen av både det subjektive, det sosiale, det institusjonelle og det legale. Kommunikativ rasjonalitet er således et systemisk begrep som tar utgangspunkt i de ulike strukturelle lagene som er med å påvirke vår forståelse av verden. Følger vi Habermas (2018), vil ingen av oss noen gang kunne «bryte helt ut» av disse strukturelle lagene. Vi er alle forankret i en struktur- og livsverden, som danner basis for hvordan vi ser på andres livsverden. Men vi kan på et strukturelt nivå si noe om betingelser for rasjonalitet som innbefatter samspillet mellom de ulike diskursene jeg har beskrevet over.

\section{Et regionalt kunnskapssystem}

Jeg følger Steve Fuller (2002) når han argumenterer for at vi bør studere nærmere hvordan forskningsbasert kunnskap påvirker konkrete holdninger, institusjoner og maktformer i samfunnet. For å kunne gjøre det må vi definere et sosialt kunnskapssystem. I vårt tilfelle er det en region. Så, hvordan kan vi bruke det som er sagt over om kunnskapens former, 
til å definere et regionalt kunnskapssystem? For det første må vi nedskalere noen av de temaene vi har vært inne på, til en regional kontekst. De fire nevnte diskursene er ikke alle spesifikke for en region. De omtaler forhold som er både nasjonale og internasjonale, men de har alle en anvendelse i en gitt region. I et regionalt kunnskapssystem finner man holdninger, normer, fordeling av økonomiske ressurser, ulike maktsentre og ulike besluttende organer. Vi kan altså finne igjen de ulike diskursene i form av verdier og forestillinger, relasjoner, maktposisjoner og institusjoner. Vi kan således tenke oss at dette sammen med kunnskapsformene konstituerer det regionale kunnskapssystemet.

Det neste spørsmålet som da reiser seg, er: Hvordan utfordres disse kunnskapsområdene av de ulike formene for kunnskap? Her kan man tanke seg at dette gir seg relativt logisk ut fra det som ellers er sagt: Normer endrer seg når folk ikke lenger aksepterer dem, verdier endrer seg når folk ikke lenger tror på dem, og så videre. Det materialet jeg skal presentere under, viser da også tydelig at de forskerne som ønsker å påvirke kunnskapsutviklingen i samfunnet, samtidig har klare ideer om hva de kan påvirke og hvordan de kan påvirke det. I tabellform vil det se slik ut:

\begin{tabular}{|l|l|l|l|l|}
\hline & $\begin{array}{l}\text { Verdier og } \\
\text { holdninger }\end{array}$ & $\begin{array}{l}\text { Interaksjonsmønstre } \\
\text { og relasjoner }\end{array}$ & $\begin{array}{l}\text { Makt og } \\
\text { posisjoner }\end{array}$ & $\begin{array}{l}\text { Institusjoner, } \\
\text { lover og regler }\end{array}$ \\
\hline $\begin{array}{l}\text { Individuell, } \\
\text { eksplisitt } \\
\text { kunnskap }\end{array}$ & $\begin{array}{l}\text { Endring av } \\
\text { personlige } \\
\text { preferanser }\end{array}$ & $\begin{array}{l}\text { Endret individuell } \\
\text { reaksjon på normer og } \\
\text { mønstre }\end{array}$ & $\begin{array}{l}\text { Individuell } \\
\text { «protest» mot } \\
\text { makt og posisjoner }\end{array}$ & $\begin{array}{l}\text { Individuell kritikk } \\
\text { av institusjoner og } \\
\text { lover }\end{array}$ \\
\hline $\begin{array}{l}\text { Kollektiv, } \\
\text { eksplisitt } \\
\text { kunnskap }\end{array}$ & $\begin{array}{l}\text { Endring i } \\
\text { kollektive } \\
\text { preferanser }\end{array}$ & $\begin{array}{l}\text { Kollektiv endring av } \\
\text { normer og mønstre }\end{array}$ & $\begin{array}{l}\text { Kollektiv reaksjon } \\
\text { på makt og } \\
\text { posisjoner }\end{array}$ & $\begin{array}{l}\text { Kollektiv reaksjon } \\
\text { på institusjoner, } \\
\text { lover og regler }\end{array}$ \\
\hline $\begin{array}{l}\text { Individuell, } \\
\text { implisitt } \\
\text { kunnskap }\end{array}$ & $\begin{array}{l}\text { Endring i } \\
\text { personlige verdier } \\
\text { og holdninger }\end{array}$ & $\begin{array}{l}\text { Endring i opplevelse } \\
\text { av legitimitet til } \\
\text { sosiale grupper }\end{array}$ & $\begin{array}{l}\text { Endret tiltro til } \\
\text { makt og posisjoner }\end{array}$ & $\begin{array}{l}\text { Endring i syn og } \\
\text { tro på institusjoner } \\
\text { samt ønske om } \\
\text { endring av lovverk }\end{array}$ \\
\hline $\begin{array}{l}\text { Kollektiv, } \\
\text { implisitt } \\
\text { kunnskap }\end{array}$ & $\begin{array}{l}\text { Endring i } \\
\text { kollektive verdier } \\
\text { og holdninger }\end{array}$ & $\begin{array}{l}\text { Ending av sosiale } \\
\text { mønstre }\end{array}$ & $\begin{array}{l}\text { Endrede holdninger } \\
\text { og opplevelse av } \\
\text { legitimitet til makt } \\
\text { og posisjoner }\end{array}$ & $\begin{array}{l}\text { Endrede } \\
\text { holdninger til og } \\
\text { opplevelse av } \\
\text { legitimitet }\end{array}$ \\
\hline
\end{tabular}

Tabell 1. Hvordan endres det regionale kunnskapssystemet.

Tabellen kan leses slik: Hvis du vil påvirke individers verdier som kan anses som implisitt kunnskap, må du velge en forskningstilnærming som 
adresserer endring i personlige verdier og holdninger. Hvis ditt fokus er interaksjonsmønster i form av hvordan dette uttrykker seg i eksplisitte normer, må du adressere kollektiv endring av normer og mønstre. Hvis du vil adressere implisitt, kollektiv kunnskap i forhold til autoriteter i form av makt og posisjoner, så må du komme i inngrep med holdninger og opplevelse av legitimitet til makt og posisjoner.

Svakheten med modellen over er at den ikke i tilstrekkelig grad fanger opp det vi diskuterte innledningsvis og som vi kan karakterisere som komplekse endringsmekanismer. I forhold til tabell 1 innebærer det at man ser på sammenhengen mellom endring på et kollektivt og et individuelt nivå, eller sammenhengen mellom endringer av institusjoner og endringer av holdninger. Som nevnt, er det sannsynlig at sosiale endringer skjer som en parallell bevegelse av institusjoner, regler, holdninger og normer. Likevel kan tabellen være nyttig som ramme for å analysen her. Intensjonen min er, som nevnt innledningsvis, begrenset til å se på hvordan den forskningsbaserte kunnskapen adresserer ulike deler av kunnskapssystemet og forsøker å påvirke dette.

\section{Det empiriske materialet: Forskning på Agder}

I den empiriske delen av dette kapitlet skal jeg forsøke å vise med utgangspunkt i forskningsprosjekter på Agder, hvordan forskning retter seg inn mot ulike sidene av et regionalt kunnskapssystem slik det er beskrevet over. Det materialet jeg skal bruke, er hentet fra fire forskersamarbeid jeg har ledet, og som har resultert i fire bøker (Johnsen, Halvorsen \& Repstad, 2009; Johnsen \& Amundsen, 2014; Johnsen, Torjesen \& Ennals, 2015; Johnsen, Hauge, Magnussen \& Ennals, 2016).

I alle de fire bokprosjektene er forskerne blitt bedt om å redegjøre for sine strategier for å få til endringer i samfunnet. Tilsammen er 55 forskningsprosjekter presentert i disse fire bøkene. De aller fleste adresserer utfordringer i egen region, altså Agder. Alle er relevante for egen region selv om de adresserer mer generelle problemstillinger. Alle forskerne er fra Agder, nærmere bestemt Universitetet i Agder (tidligere Høgskolen i Agder) og Agderforskning. Det er en viss skjevhet i utvalget i retning av samfunnsforskning. Boken Forskning møter praksis (Johnsen 
\& Amundsen, 2014) var skrevet på vegne av Institutt for arbeidsliv og innovasjon ved UiA, som i dag er en del av det som heter Handelshøyskolen ved UiA. Boken Applied Social Science Research in a Regional Knowledge System (Johnsen et al., 2016) var skrevet på oppdrag fra Agderforskning (nå del av NORCE), som var et samfunnsforskningsinstitutt. De to andre bøkene, derimot, er initiativ der samtlige fakulteter ved Universitetet i Agder har deltatt. Det første bokprosjektet, som ble kalte $\AA$ forske blant sine egne (Johnsen et al., 2009), var et initiativ som kom fra forskerne selv. Det andre, som ble til boken Higher Education in a Sustainable Society (Johnsen et al., 2015), var et initiert fra rektoratet ved Universitetet i Agder.

\section{Forskningsstrategi og forskningsfelt}

Vi skal nå se på de mønstrene som danner seg når vi klassifiserer de 55 prosjektene. Som nevnt er disse prosjektene forskernes egen beskrivelse av hva de har gjort, og i noen tilfeller også beskrivelse av hvilke strategier de har fulgt og hvorfor. Vi kan legge til grunn en antagelse om at forskere retter sin forskning inn mot det feltet de vil påvirke, og velger strategier ut fra dette, inkludert valg av metode eller metodologi. Metoden under er å konstruere noen kategorier og se om de mønstrene vi får fram, støtter opp om de antagelsene jeg har formulert. Jeg begynner med forskerens valg av forskningsstrategi i forhold til forskningsfelt og bruker samme inndeling som er brukt i Applied Social Science Research in a Regional Knowledge System.

Det er videre naturlig å tenke seg at forskerens strategi har betydning for hvordan forskeren samhandler med praksisfeltet. Eksempelvis, hvis man har som mål med sitt arbeid å hjelpe en spesiell organisasjon eller en spesiell gruppe mennesker, så vil ens forskningsstrategi være rettet inn mot dette. Har man som mål å delta i en overordnet diskusjon om regioners utvikling, så vil likeledes hvordan man forsker, og hva slags materiale som er relevant, i noen grad styres av dette. I figur 1 under er det skilt mellom hvorvidt forskeren adresserer et individuelt, et sosial eller et strukturelt samfunnsnivå.

Det er også naturlig å tenke seg at forskningsmetode er tilpasset det feltet man er engasjert i. Statistiske studier vil, for eksempel, være mer 
relevant hvis man retter seg mot strukturelt eller sosialt nivå, enn hvis man har et individ eller en individuell situasjon i fokus. Man kan likeledes tenke seg at man må være «nærere på» praksis hvis man skal ha en tett dialog med enkeltmennesker enn hvis man ser på strukturelle forhold i en region. Man kan stå på avstand som en observatør hvis man skal analysere strukturelle endringer i samfunnet. Under er de 55 prosjektene summert opp i form av hvor mange prosjekter som faller innenfor de enkelte kombinasjonene ut fra disse kategoriene.

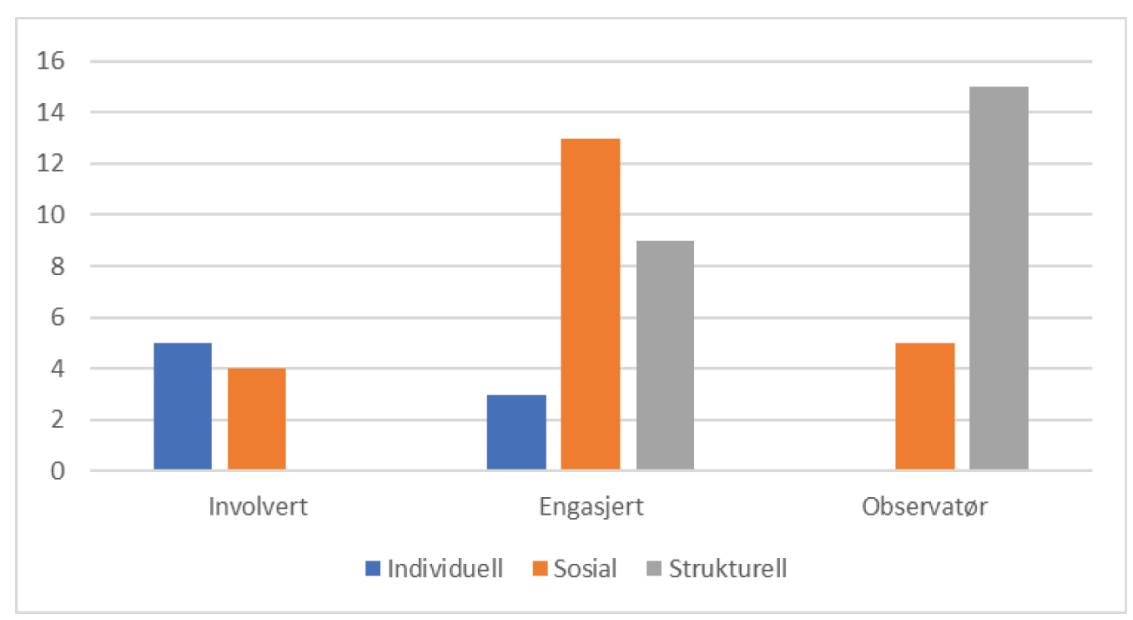

Figur 1. Forskningsstrategi og forskningsfelt.

Det er viktig å understreke at det materialet som ligger til grunn her, ikke er et representativt eller «statistisk» utvalg. Man kan ikke trekke for vidtgående konklusjoner på grunnlag av dette materialet. Det som er hensikten med oversikten over, er å se på selve mønsteret. I stor grad bekrefter det en hovedantagelse om at hvis man arbeider rettet mot enkeltindivider, så arbeider man mer involvert enn hvis man arbeider med strukturelle utfordringer i samfunnet. Av de prosjektene som er representert i utvalget, ser vi at den største gruppen er «engasjerte» forskere.

I begrepet engasjert ligger det en vurdering av at prosjektene har en viss normativ profil. Engasjert er en kategori mellom det å være involvert på den ene siden og en observatør på den andre. Engasjert innebærer at forskeren er tett på praksis og har sterk interaksjon med praksis eller har et sterkt normativt engasjement. Vi ser at denne typen forskning 
adresserer spørsmål både på et individuelt, sosialt og strukturelt nivå. Et eksempel på et prosjekt som er klassifisert som engasjert på individnivå, er et etnografisk prosjekt som hadde til formål å skape bedre forståelse i virkemiddelapparatet for integrering av somaliske kvinner i en kommune på Agder. Et eksempel på engasjert forskning på et strukturelt nivå er et prosjekt som diskuterer hvordan man kan få til et økt fokus på bærekraft i ingeniørutdanningen.

En illustrasjon av prosjekter i gruppen involvert/individuell er et prosjekt som handler om en fenomenologisk tilnærming til spørsmålet om hvilke utfordringer unge musikktalenter møter gjennom utdanningssystemet. Prosjektet har fulgt noen få musikkelever over tid, og innsikten fra prosjektet har hatt stor betydning for diskusjonen om organisering av musikkutdanningen i videregående skole. Vi finner også i denne gruppen et prosjekt som adresserer det å være en moderne prest. I gruppen engasjert/ sosial har vi plassert et prosjekt om CSR på Agder, der prosjektet har hatt til hensikt å skape økt bevissthet rundt temaet sosialt ansvar. Vi finner også et prosjekt om samspill mellom studenter og lærere i utdanning. Innenfor gruppen observatør/strukturelt har vi et prosjekt om klyngeutvikling på Agder, der argumentet er at innovasjonspolitikken i større grad bør rette seg inn mot å støtte opp om utvikling av næringsklynger. Her finner vi også prosjekter om ernæringspolitikk, om innføring av LEAN-konsepter i virksomheter og diskusjoner om universiteters samfunnsoppdrag.

Vi ser at prosjekter med en engasjert forskningsprofil som adresserer en spesifikk sosial gruppe eller tema, utgjør flesteparten av disse prosjektene. Vi ser også at den største enkeltgruppen av prosjekter er prosjekter der forskeren står «på avstand» som observatør og analyserer strukturelle forhold i samfunnet. Flere av disse prosjektene handler om utviklingen av universitetet i regionen og om regional innovasjonspolitikk. De to blanke kategoriene gir en viss bekreftelse på at logikken i figuren gir mening. Det er ikke forventet at man finner prosjekter med disse profilene.

\section{Hjelpende, bekreftende eller kritisk forskning}

Ut fra betraktningene over kan det være av interesse å se å hvilken forestilling forskeren har om sin egne rolle i prosjektet. Slik vi definerte 
forholdet mellom involvert, engasjert og observatør over, gikk skillet på grad av normativitet. Men hva ligger i dette «normative» engasjementet? Ønsker man å hjelpe, bekrefte, styrke eller å kritisere noe? I figur 2 under har vi forsøkt å klassifisere prosjektene ut fra hva forskerne sier eksplisitt, eller hva vi leser ut av prosjektene ut ifra hvilken intensjon prosjektet har. Likeledes har vi skilt mellom hvorvidt prosjektene retter seg mot individer, mot det sosiale/kulturelle system eller mot organisasjoner og institusjoner.

Som man vil se under, er det ingen nødvendig sammenheng mellom mønstrene i figur 1 og 2. Ser vi på gruppen individuell i figur 1, så er det 8 prosjekter. I figur 2 er det 7 prosjekter som er klassifisert som individuelt. Likeledes er det med de andre kategoriene. Forskjellen skyldes at i figur 1 så vi på hvem prosjektet tar utgangspunkt i, hva som er deres empiriske grunnlag. I figur 2 er det utfallet av prosjektet som er vurdert. Eksempelvis kan man studere en person på en institusjon med tanke på å forstå personens situasjon, men man kan samtidig bruke denne innsikten til å kritisere (eller hjelpe) institusjonen. Ut fra disse vurderingene gir vårt materiale følgende mønster:

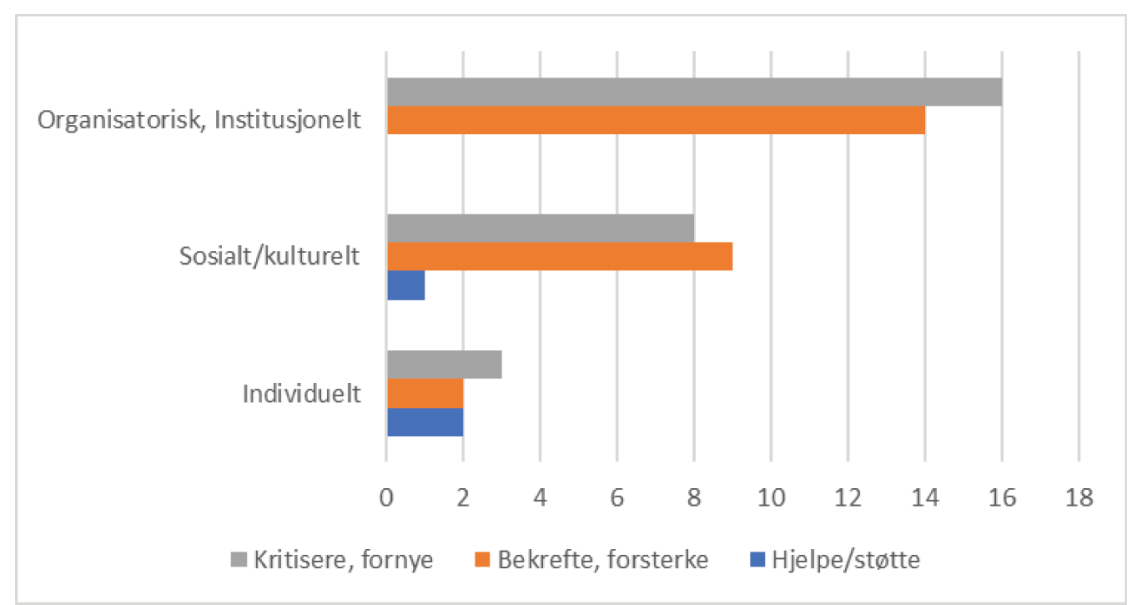

Figur 2. Hjelpende, bekreftende eller kritisk forskning.

Av figur 2 ser vi at mens noen ganske få prosjekter er rettet mot å være hjelpende eller støttende, er hovedtyngden av dem enten bekreftende eller forsterkende på de praksiser man studerer eller kritiske (alternativt 
fornyende) i forhold til disse praksisene. I forhold til de to siste kategoriene, bekreftende eller kritisk, deler materialet seg sånn noenlunde på midten. De fleste prosjektene retter sin argumentasjon mot et organisatorisk/institusjonelt nivå. Av disse er omtrent halvparten bekreftende og halvparten kritiske. Bekreftende prosjekter vil typisk være prosjekter der forskeren ut fra empiriske funn kommer med forslag til mindre justeringer eller forbedringer av praksis. Kritiske prosjekter vil typisk påpeke at nåværende praksis ikke er gunstig og bør endres. For å illustrere det første, kan vi vise til et prosjekt som har foreslått en ny og bedre forretningsmodell for kulturinstitusjoner, som eksempel på det siste kan vi vise til et prosjekt om bærekraftig diett, som sier at nåværende spisemønster (og dermed landbruksproduksjon) ikke er bærekraftig.

\section{Forskningens betydning for et regionalt kunnskapssystem}

Hvordan kan vi tenke oss at den forskningen som er klassifisert over, påvirker et regionalt kunnskapssystem? Igjen er klassifiseringen gjort uavhengig av figurene 1 og 2 over. Spørsmålet vi har stilt for å kunne foreta klassifiseringen under, er hvem og hva det er som potensielt blir påvirket gjennom forskningen. Hvis vi plasserer prosjektene i den modellen for det regionale kunnskapssystemet vi har utviklet tidligere (tabell 1), får vi fram følgende mønster:

Det kanskje mest påfallende mønsteret som fremkommer gjennom figur 3, er at mens 30 av 55 prosjekter i figur 2 ble klassifisert som at de adresserte et institusjonelt/organsatirisk nivå, så er det i figur 3 kun 17 prosjekter som direkte kommer med innspill til institusjoner, lover eller regler. Av disse igjen retter kun 9 seg til det vi har kalt kollektiv eksplisitt kunnskap. Med andre ord er det bare en liten del av forskningen som forsøker å påvirke konkrete institusjoner eller lover/regler i samfunnet. Brorparten av prosjektene er vesentlig «mykere» i formen. Den største gruppen retter seg mot interaksjonsmønstre og relasjoner.

Ut fra figur 3 kan vi med de forbeholdene vi har gjort tidligere, muligens se noen trekk som sier noe om hvordan et regionalt universitet og en regional forskningsstiftelse interagerer med et regionalt kunnskapssystem. For 


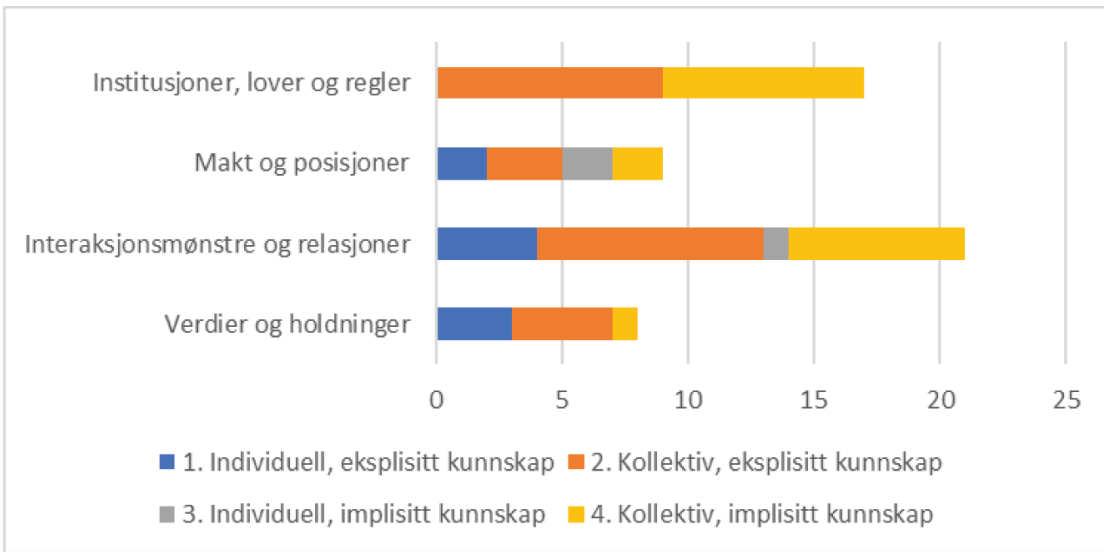

Figur 3. Forskningens påvirkning på det regionale kunnskapssystemet.

det første er bredden av prosjekter påtagelig. Så å si alle sider av et kunnskapssystem slik det her er definert, kan være gjenstand for forskning. For det andre kan oversikten over supplert med figur 1 og 2 indikere at mye forskning på Agder har vært en form for «samskaping», det vil si at den retter seg mot de verdier og praksiser man har på Agder. Fra figur 2 vet vi at bortimot halvparten av disse er kritiske, mens den andre halvparten er bekreftende.

Refleksjoner basert på det foreliggende empiriske materialet må naturligvis ses i lys av de forbehold som er tatt, inkludert at vi i det materialet som er presentert, ikke har data på i hvilken grad forskningen har lyktes med å påvirke kunnskapsutvikling. Eksempelvis, hvis vi ser på prosjektet Gud på Sørlandet, er det er vanskelig å si om det har bidratt til økt sekularisering eller en mer liberal praktisering av religion. At det har vært en slik utvikling, er sannsynlig, men årsak er vanskeligere å påberope. Likeledes er det vanskelig å si om prosjektet Getting Chinaready har gitt oss flere kinesiske turister, eller om prosjektet Women network har bidratt til flere kvinner i ledende stillinger. Likevel, hvis vi antar at de 55 prosjektene gir et visst bilde av den forskningen som foregår ved et regionalt universitet og forskningsinstitusjon, hva forteller dette oss?

Vi startet med å skille mellom en lineær, interaktiv og systemisk forståelse av forskningens betydning. Jeg vil argumentere for at når vi skal forstå 
forskningens betydning samlet, så fanger en systemisk tilnærming bedre denne helheten enn de to andre modellene, den lineære og den interaktive. I det materialet jeg har presentert, er det eksempler på både lineære og interaktive prosjekter, men likevel er mitt argument at for å forstå den samlede betydningen av forskning i forhold til et kunnskapssystem, så er den systemiske tilnærming i form av kunnskapssosiologi nødvendig.

Videre har vi definert det regionale kunnskapssystem i form av kunnskapsformer og diskurser. Her finner jeg at det Habermas ville kalle den etiske diskursen, er den diskursen som forskningen i størst grad retter seg mot. Dette tilsier en klar regional forankring av forskningen fordi den etiske diskursen er definert som en sosial og kontekstuelt basert diskurs. Det er en diskurs der man i stor grad må være en «insider» for å kunne delta. Det er også en diskurs der forskningen selv er en del av diskursen, og der man således står overfor et betydelig selvreferanseproblem; man forsker på noe man selv er en del av. En av verdiene av å diskutere hvordan forskningen inngår i et regionalt kunnskapssystem, kan således være å bevisstgjøre denne selvreferanseproblematikken og dermed skape større kommunikativ rasjonalitet i møtet mellom forskningen og praksis.

\section{Konklusjon: Forskningens regionale betydning}

I dette kapitlet har jeg forsøkt å gjøre to ting; for det første definere et regionalt kunnskapssystem og for det andre, basert på et empirisk materiale fra Agder, forsøke å se på hvordan forskning påvirker det regionale kunnskapssystemet.

Jeg har hevdet at endringer i kunnskap gir sosiale endringer når dette skjer som en parallell bevegelse av institusjoner, regler, holdninger og normer i samfunnet. Hvis vi således skal forstå effekten av forskning, altså forskningens regionale betydning, må vi se på den samlede betydning den har på alle disse områdene. Den empiriske delen av kapitlet har vært begrenset til å se på hvordan den forskningsbaserte kunnskapen i utvalgte prosjekter fra Agder har adressert ulike deler av det regionale kunnskapssystemet og forsøkt å påvirke dette.

Selv om det ikke kan trekkes generelle konklusjoner ut fra empirien som er presentert, opprettholdes argumentet om at forskningens 
regionale rolle og betydning er langt mer kompleks enn det de to mest refererte modellene, den lineære modellen og interaksjonsmodellen, ser ut til å anta. Empirien tilsier at det er et mangfold av tilnærminger til å påvirke den regionale kunnskapen. Videre tilsier empirien at forskerne har stor grad av bevissthet om strategier for å påvirke sosial kunnskap. Den viser også at det er et mangfold av slike strategier, og at de både er kritiske og bekreftende. Det er således meningsfullt å si at den samlede effekt av disse innspillene og aktivitetene fra forskerne er noe mer enn hvert enkelt forskningsprosjekt. Hva den samlede systemiske virkningen er, er vanskelig å påvise. Likevel vil jeg ut fra dette argumentere for at et kunnskapssosiologisk perspektiv på forskningen er en fruktbar tilnærming til å forstå forskningens regionale betydning.

\section{Referanser}

Bell, D. (1973). The coming of the post-industrial society. New York: Basic Books.

Breit, E., Fossestøl, K., Pedersen, E. \& Thorbjørnsrud, T. (2017). Samarbeidsdrevet innovasjon i NAV. AFI-rapport 2017:5. Oslo: Arbeidsforskningsinstituttet, Høgskolen i Oslo og Akershus.

Comte, A. (1988) [1830]. Introduction to positive philosophy. Cambridge: Hackett Publishing Company.

Durkheim, E. (2000) [1902]. De la division you travail social. Nordic edition 2000: About the social division of labor. Copenhagen: Hans Reitzels Forlag.

Etzkowitz, H., \& Leydesdorff, L. (2000). The dynamics of innovation: From national systems and 'mode 2 ' to a triple helix of university-industry-government relations. Research policy, 29(2), 109-123.

Feyerabend, P. (2010) [1975]. Against method. New York: Verso Books.

Florida, R. (1995). Toward the learning region. Futures, 27(5), 527-36.

Fuller, S. (2002). Social epistemology. Indiana: Indiana University Press.

Gibbons, M., Limoges, C., Nowotny, H., Schwartzman, S., Scott, P. \& Trow, M. (1994). The new production of knowledge: The dynamics of science and research in contemporary societies. London: Sage.

Habermas, J. (2007) [1968]. Knowledge and human interest. Cambridge: Polity Press. Habermas, J. (1981). Theori des kommunikativen. Engelsk oversettelse: McCarthy, T. (1997). The theory of communicative action. Vol 1: Reason and the realization of society. Vol 2: Lifeworld and system: A critique of functionalist reason. London: Polity Press.

Habermas, J. (2018). Philosophical introductions: Five approaches to communicative reason. Cambridge: Polity Press. 
Holzner, B. \& Marx, J. H. (1979). Knowledge application: The knowledge system of society. Boston: Allyn and Bacon.

Johnsen, H. C. G. \& Amundsen, I. (Red.). (2014). Forskning møter praksis. Kristiansand: Portal.

Johnsen, H. C. G., Halvorsen, A. \& Repstad, P. (Red.). (2009). Å forske blant sine egne: Universitet og region - noerhet og uavhengighet. Kristiansand: Høyskoleforlaget.

Johnsen, H. C. G., Hauge, E. S., Magnussen, M. L. \& Ennals, R. (Red.). (2016). Applied social science research in a regional knowledge system: Balancing validity, meaning and convenience. New York: Routledge.

Johnsen, H. C. G., Holtskog, H. \& Ennals, R. (2018). Coping with the future: Rethinking assumptions for society, business and work. London: Routledge.

Johnsen, H. C. G., Torjesen, S. \& Ennals, R. (2015). Higher education in a sustainable society: A case for mutual competence. Heidelberg: Springer.

Karlsen, J., Larrea, M., Wilson, J. R. \& Aranguren, MJ. (2012). Bridging the gap between academic research and regional development in the Basque Country. European Journal of Education, 47(1), 122-138.

Knorr-Cetina, K. (1999). Epistemic cultures: How the sciences make knowledge. Cambridge, MA: Harvard University Press.

Kuhn, T. S. (1970) [1962]. The structure of scientific revolutions. Chicago: Chicago University Press.

Kunnskapsdepartementet (2018). Langtidsplan for forskning og høyere utdanning 2019-2028. (Meld. St. 4 2018-2019). Oslo: Kunnskapsdepartementet.

Levin, M. \& Greenwood, D. (2001). Pragmatic action research and the struggle to transform universities. I H. Bradbury \& P. Reason (Red.), Handbook of action research: Participative inquiry and practice. London: Sage.

Machlup, F. (1984). Knowledge: Its creation, distribution and economic significance. Princeton: Princeton University Press.

Mannheim, K. (1979) [1929]. Ideology and utopia: An introduction to the sociology of knowledge. London: Routledge and Keegan Paul.

Merton, R. A. (2005) [1945]. The sociology of knowledge. I N. Stehr \& V. Meja (Red.), Society and knowledge: Contemporary perspectives in the sociology of knowledge and science. New Brunswick, NJ: Transaction Books.

Nowotny, H., Scott, P. \& Gibbons, M. (2001). Rethinking science: Knowledge production and the public in an age of uncertainty. Oxford: Polity Press.

Pinheiro, R., Normann, R. \& Johnsen, H. C. G. (2016). External engagement and the academic heartland: The case of a regionally-embedded university. Science and Public Policy, 43(6), 787-797.

Riksrevisjonen (2017). Riksrevisjonens kontroll med forvaltningen av statlige selskaper for 2016. Dokument 3:2 (2017-2018). Oslo: Riksrevisjonen. 
Rodrigues, M. J. (2002). The new knowledge economy in Europe: A strategy for international competitiveness and social cohesion. Cheltenham: Edward Elgar.

Scheler, M. F. (1973). Selected philosophical essays. Evanston, IL: Northwestern University Press.

Schütz, A. (1972) [1932]. The phenomenology of the social world. London: Heinemann Educational Books.

Stehr, N. \& Meja, V. (Red.). (2005). Society and knowledge: Contemporary perspectives in the sociology of knowledge and science. New Brunswick, NJ: Transaction Books.

Stehr, Nico. (1994). Knowledge societies. London: Sage.

Toulmin, S. \& Gustavsen, B. (1996). Beyond theory: Changing organisations through participation. Amsterdam: John Benjamins Company.

Weber, M. (1947). The theory of social and economic organization. Oxford: Oxford University Press. 


\title{
KAPITTEL 6
}

\section{Den tredje rollen: Fra distriktshøgskole til universitet}

Roger Normann

NORCE Norwegian Research Centre

Rómulo Pinheiro

Universitetet i Agder

\begin{abstract}
This chapter discusses the evolution of third-mission collaboration by tracking the historical unfolding of third-mission engagement in the Norwegian higher education sector and against the backdrop of changes in the institutional profiles and legal statuses of domestic providers. We categorise developments into four distinct phases and develop a novel typology on the evolution of third-mission roles and the tensions that emerge from this, to be empirically tested and applied in other geographical contexts. The research problem being addressed is: What characterises third-mission engagement in the transition from regional college to a full-fledged university? The findings are of relevance to managers and policy makers, in addition to social science researchers interested in the topic.
\end{abstract}

Keywords: university collaboration, third-mission, engagement, tensions, university governance, Norway

\section{Introduksjon}

Flere av de nye unge universitetene, som Universitetet i Sørøst-Norge, Universitetet i Agder, Universitetet i Stavanger og Nord universitet deler institusjonell historie ved at de er resultat av flere fusjonsprosesser

$1 \quad$ Kapitlet er en original videreutvikling i norsk språkdrakt av forskning først presentert av forfatterne i boka Higher Education and Regional Development (Pinheiro et al., 2018). Kapitlet bygger på forskning utført innenfor Czech-Norwegian Research Programme (EEA Grants 2014-2021).

Sitering av dette kapitlet: Normann, R., \& Pinheiro, R. (2019). Den tredje rollen: Fra distriktshøgskole til universitet. I J. P. Knudsen \& T. Lauvdal (Red.), Geografi, kunnskap, vitenskap. Den regionale UH-sektorens framvekst og betydning (s. 155-175). Oslo: Cappelen Damm Akademisk. https://doi.org/10.23865/noasp.73.ch6. Lisens: CC BY 4.0 
mellom tidligere distriktshøgskoler. Særlig var det høgskolereformen i 1994, der en rekke høgskoler ble samlet, som drev frem denne utviklingen. Det nasjonale høyere utdanningslandskapet har etter dette kontinuerlig vært i prosess mot sammentrekning og konsentrasjon. Felles for distriktshøgskolene, som ble høgskoler og senere universiteter, er at de ofte har vært tett knyttet til de stedene der de har vært lokalisert. Mange av disse stedene har vært det som ofte kalles rurale og institusjonelt tynne regioner (Amin \& Thrift, 1995), der høgskolene ofte hadde rollen som kunnskapsnoder som produserte kunnskapsarbeidere til privat og offentlig virksomhet. De var også viktige som kunnskapsleverandører og samarbeidspartnere til små og mellomstore virksomheter og mange steder også som en av de største arbeidsplassene. For en lokalbefolkning der mange hadde fått hele eller deler av egen utdanning ved distriktshøgskolen, bidro nok denne også til å forsterke følelse av tilhørighet og identitet med stedet. I overgangen fra distriktshøgskole til fusjonert høgskole og fra fusjonert høgskole til universitet var det mange steder også et viktig perspektiv i fusjonsprosessen å bevare denne identiteten og tilhørigheten til institusjonen i befolkningen.

Samtidig skulle de nye høgskolene og universitetene møte en annen utfordring. Hvordan skulle man arbeide for å møte kravene til det som i økende grad var en konkurranseutsatt sektor med økte krav til forskningskvalitet, internasjonalisering og konkurranse om forskningsmidler og forskningstalenter? Dette gjorde at de nye institusjonene måtte håndtere et tilsynelatende dilemma: Hvordan kunne man for det første utvikle interne strukturer, arbeidsrutiner og insitamenter som gjør at man overlever og vokser i takt med økt nasjonal og internasjonal konkurranse om studenter og forskningsmidler? Samtidig som man for det andre bevarte sin institusjonelle og lokale identitet og ivaretok komplekse og ofte motstridende behov og forventninger hos regionale aktører? Det mulige dilemmaet kan da bestå i at lokale behov og forventninger ikke er kompatible med økte krav og forventninger til eksellens innenfor undervisning og forskning. I dette kapitlet drøfter vi med utgangspunkt i institusjonell teori noen av utfordringene knyttet til utvikling av den tredje rollen når distriktshøgskoler blir universiteter. Den tredje rollen, den regionale utviklingsrollen, er og har vært diffust forstått og praktisert. 
Den betyr også ulike ting innenfor ulike fagdisipliner. Men fellesnevnere knyttet til rollen vil inkludere begreper som relevans, nytte, samarbeid og direkte interaksjon mellom fagmiljøer og personer og institusjoner som er utenfor en klassisk akademisk sfære, og som ofte kun har begrenset erfaring med denne. Spørsmålet vi på bakgrunn av dette søker å belyse, er: Hva kjennetegner utviklingen av den tredje rollen når høgskoler blir universitet?

Den tredje rollen kan på grunn av sin kompleksitet og uklarhet skape målkonflikter, målkonflikter som kan være større enn dem knyttet til de mer institusjonaliserte og bedre forståtte, som forskningsrollen og undervisningsrollen. Et utgangspunkt for dette kapitlet er at denne type målkonflikter knyttet til den tredje rollen vil komme til overflaten i fusjonsprosesser og i overgangen mellom ulike institusjonelle statuser.

Dette kapitlet bygger på forskning utført innenfor Czech-Norwegian Research Programme (EEA Grants 2014-2021), og et prosjekt som gikk mellom 2015 og 2017 om universitetets utviklingsroller i perifere regioner ${ }^{2}$ I tillegg trekker vi veksler på forskning og anvendte prosjekter vi har utført på og for høyere utdanningsinstitusjoner både i Norge og internasjonalt ${ }^{3}$. Resten av kapitlet er strukturert slik at vi først redegjør kort for noen nasjonale utviklingstrekk som er vesentlige for praktiseringen av den tredje rollen. Deretter drøfter vi, i hovedsak med utgangspunkt i institusjonell teori (March \& Olsen, 1989, 1995; Olsen, 2007), et rammeverk for å fortolke utvikling av den tredje rollen. Kapitlet konkluderes med en analyse og ved at vi går tilbake til forskningsspørsmålet og trekker frem noen hovedfunn og refleksjoner.

2 Mer info her: http://www.perifproject.eu/

3 a) Moving Towards the Responsible University? A cross-disciplinary network on higher education's role in the context of growing social and economic inequalities (2017-2018). b) UiA+HiT? Organisasjonsmodeller, næringsutvikling og funksjonell region (2013). c) Mulighetsstudie for Technology Transfer Office (TTO) ved Universitetet i Agder (2011). d) Higher education and regional development. The University and College Network for Western Norway. e) Utredning av alternative modeller for kommersialisering av forskning ved Universitetet i Agder (2018). f) Higher education and regional development. The University and College Network for Western Norway (2019-2020). g) Assessing the contribution of the higher education sector to welfare creation in Indonesia (2015-2016). 'Neighbours in different worlds? Comparing university strategies and roles in Indonesia and Singapore' (2016-2017). 


\section{Nasjonale utviklingstrekk og styringssignaler}

Norsk høyere utdanning har tradisjonelt hatt en binær inndeling bestående av universiteter og høgskoler, der høgskolene typisk har hatt en hovedrolle med å gi tilbud om yrkes- og profesjonsutdanninger og universitetene med fagutdanningene. Flere norske utdanningsinstitusjoner har forløpere som strekker seg tilbake til tidlig 180o-tall. Men det er først etter andre verdenskrig og i særlig grad på 1960- og 70-tallet at man systematisk får etablert regionale høgskoler (distriktshøgskoler) over hele landet (Kyvik, 1981). Fra et styringsperspektiv ble distriktshøgskolene til som et resultat av en konvergens mellom distriktspolitikken og utdanningspolitikken, der målsettinger knyttet til å bevare bosetting og arbeidsplasser i distriktene gjennom å forberede det på kunnskapssamfunnet sto sentralt (Bleiklie et al., 2000).

Høgskolene som vi kjenner dem i dag, er i stor grad et resultat av fusjoner mellom tidligere statlige, regionale og distriktshøgskoler. Den første store fusjonsbølgen foregikk på 1990-tallet og ble initiert av Brundtlandregjeringen og satt ut i livet av daværende statsråd Gudmund Hernes. Målet med høgskolereformen var at høgskolene skulle drives mer effektivt ved hjelp av stordriftsfordeler. Dette var en ikke frivillig prosess, men den var effektiv ved at den resulterte i at 98 høyere utdanningsinstitusjoner i 1994 ble fusjonert til 26 høgskoler (Kyvik, 2002).

Den nasjonale politikken om hva som var høgskolens rolle og ansvar, har endret seg de siste 50 årene. I 1968 uttalte regjeringen at den viktigste forskjellen mellom et universitet og en høgskole var at sistnevnte ikke skulle engasjere seg i forskning (Kirke- og undervisningsdepartementet, 1968). En konsekvens av dette var at høgskolen heller ikke kunne ha en forskningsbasert tredje-rolle eller forskningsbasert undervisning. Allerede i 1970 ble denne posisjonen justert. Nå mente regjeringen at høgskoler kunne engasjere seg i forskningsbaserte aktiviteter med sikte på å adressere anvendte forskningsbehov i sine regioner/distrikter. Regjeringen mente videre at høgskolene i lys av sin institusjonelle profil først og fremst var egnet til å engasjere seg i forskning relatert til samfunnsvitenskap og humaniora. De skulle ikke drive med naturvitenskapelig eller teknologisk forskning. Dette skulle være forbeholdt de etablerte universitetene (Kirke- og undervisningsdepartementet, 1969). Etter høgskolereformen i 158 
1994 ble dette igjen endret. Nå het det at alle aktiviteter, inkludert tredje-rolle-aktiviteter, på alle utdanningsinstitusjoner i Norge skulle være forskningsdrevet (Universitets- og høyskoleloven, 1995). Distriktshøgskolene hadde vært en suksess i den forstand at de hadde hatt en rask vekst utover på 1970- og 80-tallet, en utvikling drevet frem av en økende etterspørsel etter sykepleiere, økonomer, ingeniører og lærere (Pinheiro \& Stensaker, 2018).

Flere har påpekt at vi ikke har en autorativ definisjon av hva som menes med «den tredje rollen» (Gulbrandsen \& Nerdrum, 2009). Dette gjenspeiles også i mange strategiprosesser ved norske universiteter og høgskoler, en øvelse som gjerne kommer til i etterkant av at et nytt rektorat er tilsatt eller valgt og skal ta fatt på sin gjerning, eller i forbindelse med en fusjonsprosess. Likevel inneholder disse dokumentene fra disse strategiprosessene gjerne formuleringer som uttrykker at det tredje oppdraget er like viktig som forskning og undervisning (Gulbrandsen \& Nerdrum, 2009). Det at institusjonene uttrykker viktigheten av den tredje rollen, er imidlertid et relativt nytt fenomen i Norge og noe som har forsterket seg i årene etter at vi fikk Universitets- og høyskoleloven, 1995.

\section{Den tredje rollen}

\subsection{Perspektiver og kunnskap}

Det finnes ingen universell, internasjonal definisjon av hva den tredje rollen innenfor høyere utdanning skal innebære. Samtidig er forskere generelt enige om at dette er en rolle og et mandat som skiller seg fra den første (undervisning) og den andre (forskning). Den tredje rollen har sitt opphav i USA og i Storbritannia, i USA ved etableringen av Land-Grant Colleges på 180o-tallet (Christy \& Williamson, 1992) og i Storbritannia ved etableringen av «civic» eller «red brick»-universiteter rundt industribyer som Manchester, Liverpool og Newcastle mfl. (Whyte, 2015). Både LandGrant Colleges og «red brick»-universiteter hadde fokus på landbruk og på tekniske utdanninger. De spilte i denne forstand viktige roller i den generelle industrialiseringen av samfunnet. Men det vi i dag omtaler som den tredje rolle ble, utenfor Land-Grant Colleges og«red brick»-universitetene, ikke betraktet som en del av et universitets hovedaktivitet. Dette 
var aktiviteter som ved disse institusjonene gjerne ble lokalisert i deres randsoner, ofte for å beskytte universitetet mot ekstern innflytelse, det Selznick kaller «co-optation» (Selznick, 1984 [1949]).

Engelske forskere har vært spesielt opptatt av den rolle som universiteter spiller eller kan spille i regional utvikling. John Goddard og kollegaene hans ved Newcastle University har hatt det som er blitt beskrevet som en instrumentell tilnærming til den tredje rollen (Pinheiro et al., 2015; Pinheiro et al., 2012). Goddard har fokusert på hva den tredje rollen krever av struktur, ledelse og insentiver ved institusjonen (Chatterton \& Goddard, 2000; Goddard, 1997; Goddard \& Puukka, 2008). Goddards modell ble på 2000-tallet inkludert i OECDs program for regional utvikling og innovasjon (OECD, 2007). Den inneholdt et metodisk fokus på selv-evaluering og strategisk toppledelse. Denne modellen har igjen blitt kritisert for å være normativ, for å ignorere institusjonelle tilnærminger (akademiske normer, verdier, tradisjoner osv.) og for å ikke ta nok hensyn til organisasjonenes iboende strukturelle og kulturelle kompleksitet (Pinheiro et al., 2015; Pinheiro et al., 2012). I de siste årene har forskere søkt å utvikle et konseptuelt rammeverk som komplementerer Goddards perspektiver. Det har bidratt til at argumenter både for og imot rollen har blitt mer nyanserte (Harding et al., 2007; Pinheiro et al., 2017). Blant annet viser studier at hvis universiteter skal ha en strategisk og praktisk betydning i sine omgivelser, må også den tredje rollen være tett koblet til, bygge på og bidra til undervisnings- og forskningsrollen (Benneworth et al., 2017; Pinheiro \& Benneworth, 2018; Pinheiro et al., 2018). Den tredje rolle må med andre ord, for å være meningsfull, være tett koplet både strategisk og praktisk til de øvrige av universitetets kjerneoppgaver.

\subsection{Et analytisk rammeverk}

Som vist over har vi ikke en autorativ definisjon som vi kan bygge en presis forståelse og beskrivelse av den tredje rollen på. Ulike forskningstradisjoner, ideologier og fagfelt legger et noe ulikt innhold i denne rollen. En måte å tilnærme seg begrepet på er derfor å vise noen av spenningene og motsetningene man kan finne i litteraturen 
om begrepet og rollen. Figur 1, som er en typologi tilpasset fra Normann og Pinheiro (2018), tar utgangspunkt i fire ulike teori- og forståelsesrammer om hva et universitet er, og i forlengelsen av dette en forståelse av den tredje rollen.

Én forståelse er å betrakte universiteter som en teknokratisk arena, som et instrument som skal oppfylle spesifikke samfunnsmål. Dette vil ha likheter med hva Levin og Greenwood (2016) har kalt det neoliberale, offentlige universitet. En motsats til dette vil være karikaturen av et universitet som et elfenbenstårn som er avsondret fra sine omgivelser, og der de lærde uforstyrret kan arbeide for å nå sine vitenskapelige og faglige mål. Universitetet i denne forstand er en strategisk arena først og fremst for å realisere interne mål. Mange vil likevel hevde at universiteter, deres ansatte og ledere, vil prøve å balansere både interne og eksterne mål og forventninger. I typologien under skiller vi mellom to varianter hvor universitetene er styrt av ulike institusjonelle forventninger; universiteter som deliberativ arena og universiteter som samfunnsarena.

Innenfor institusjonell teori finner vi et analytisk rammeverk som lar oss fortolke universiteter innenfor den rammen som indikeres over (March \& Olsen, 1989, 1995; Olsen, 2007). Institusjonell teori, slik den er blitt uttrykt og utviklet av March og Olsen, tar hensyn både til interne og eksterne prosesser og dynamikker og til hvordan samspillet mellom dem former institusjoner og deres utvikling. Et skille som vi da kommer frem til, er å skille mellom universitetet som instrument og universitetet som institusjon (Olsen, 2007). Denne begrepsbruken innebærer at hvis noe er et instrument, er det et middel vi bruker for å oppnå noe annet. Forstår vi universiteter som instrumenter, blir da nøkkelspørsmålet: For hvem er universitetet et instrument (Olsen, 2007)?

Selv om det er både godt empirisk og teoretisk grunnlag for å forstå og beskrive universiteters instrumentelle side (Levin \& Greenwood, 2016), har de også en institusjonell side, som vi kan forstå som normer, konstituerende regler og forventninger til passende adferd og praksis (March \& Olsen, 1998). Disse normene gir, først og fremst akademikerne, en identitet og et formål (Merton, 1973) - som ikke nødvendigvis er i samsvar med universitetet som et instrument for å nå bestemte eksterne (f.eks. politiske) agendaer. 
Institusjonelle normer, verdier og meningssystemer er relativt varige, og dermed gir de også formål og retning til personer og organisasjoner som er varige over tid, retninger som kan være i strid med eksterne dynamikker og endringer i forventninger og krav (March \& Olsen, 1998). Slike eksterne forventninger, normer og institusjonelle forventninger, slik de blir utformet i lov og regelverk for sektoren, er viktige premisser for hvordan den tredje rollen skal utformes av institusjonene. Dette kan igjen skape spenninger og motsetninger både internt i universitetsorganisasjonene og mellom universitetsorganisasjonen og dens omgivelser. Dette ser vi også i studier av norsk empiri (Stensaker et al., 2016).

I tillegg følger vi Olsen (2007) og skiller mellom universitetet som et system som primært styres av interne faktorer, og som et system som primært blir formet av eksterne krefter. Interne faktorer kan forstås som formaliserte strukturer, ledelse og strategi, men også som tause normer, verdier og identiteter knyttet til de enkelte fagdisiplinene og områdene (Becher \& Trowler, 2001). Eksterne faktorer kan for eksempel være regulativer og administrative føringer knyttet til realisering av nasjonale politiske mål.

Det å forstå universitetet som en strategisk arena betyr å forstå det som en institusjon drevet og styrt av rasjonalitet, normer og koder som ligger i de akademiske disiplinene. Universitetet er i dette perspektivet en uavhengig og selvstyrt institusjon i samfunnet, der utformingen av den tredje rollen er en konsekvens av tradisjoner og normer slik de har vært praktisert i ulike epistemiske grupperinger innenfor universitetet (Johnsen et al., 2017; Pinheiro et al., 2016). Maktstrukturen er også avledet fra posisjonen til de epistemiske grupperingene ved universitetet. Dermed er autoritet og utøvelse av lederskap koplet til en meritokratisk dimensjon der legitimitet i stor grad hentes fra faglig autoritet. Om ledere lykkes, vil avhenge av om de klarer å lage akseptable kompromisser mellom grupperinger som har divergerende synspunkter (Pellizzoni, 2001). Den tredje rollen vil innenfor den strategiske arenaen bli vurdert opp mot og utført i den grad den bidrar til en effektiv realisering av mål og ambisjoner knyttet til kjerneoppgaver som forskning og undervisning.

Forstår vi universitetet som en teknokratisk arena, er denne et instrument for å realisere mål satt av eksterne parter som offentlige 
myndigheter, næringsliv og andre. Universitetet vil her søke å manøvrere og forbedre sin relative posisjon i samfunnet ved å tilpasse sine egne strategier til de som er satt og forventet av eksterne stakeholdere. Lederskap består her av å mestre byråkratiske forventninger og det politiske spillet slik at man evner å forme et samarbeid basert på en instrumentell avstemning av egne mål og eksterne forventninger (Pellizzoni, 2001). I denne modellen vil markedsbaserte mekanismer og byråkratiske prosedyrer trumfe interne forventninger og krav fra fagdisiplinene. Den tredje rollen blir her hva eksterne stakeholdere forventer at den skal være. Frihetsgraden til universitetet ligger i eventuelle uklarheter og vaghet knyttet til hvordan den tredje rollen skal utformes. De eksterne forventningene kan også være motstridende, og de kan overstige kapasiteten universitetet har til å oppfylle dem, en problemstilling som ofte blir referert til som «mission overload» (Castells, 2001; Enders \& Boer, 2009).

Felles for de to foregående modellene er at universitetet blir et instrument for å oppnå bestemte mål, enten satt av interne eller eksterne aktører. Innenfor universitetet som en deliberativ arena-modellen, styres universitetet av de verdier og identiteter som er knyttet til normer om hva universitetet er eller kan være som demokratisk institusjon der en åpen, fri og deliberativ dialog for utveksling og utvikling av kunnskap finner sted (Levin \& Greenwood, 2016). Lederskap er i denne modellen knyttet til og legitimert av demokratiske idealer, og makt kommer her fra deliberasjonen. Den og de som kan fremsette argumenter gjennom en deliberativ prosess som vinner tilslutning i det offentlige rom, får også gjennomslag. Denne type meningsdannelse kan legge normative føringer på hva tredje-rolle-forventninger rettes mot. For eksempel vil bedrifter som ikke forstås som etiske i sin forretningsførsel, for eksempel knyttet til arbeiderrettigheter og likestilling, eller bruker teknologier som bidrar til forurensning, være samarbeidsarenaer som på grunn av at de ikke verdimessig er avstemt med verdiene til universitetet, bli nedprioritert eller svartelistet. En forventning til tredje-rolle-samarbeid innenfor denne modellen er at eksterne samarbeid blir prioritert ut ifra i hvilken grad de normativt er avstemt med eller forsterker universitetets egne normer og verdier. 


\begin{tabular}{|c|c|c|}
\hline Governance: & Styrt av interne prosesser & Styrt av eksterne prosesser \\
\hline $\begin{array}{l}\text { Instrumentell } \\
\text { (mål-middel- } \\
\text { rasjonalitet) }\end{array}$ & $\begin{array}{l}\quad \text { Strategisk arena } \\
\text { Maktbase: } \\
\text { De akademiske disiplinene } \\
\text { Lederskap (suksess) } \\
\text { Evne til å finne instrumentelle } \\
\text { kompromisser mellom interne } \\
\text { stakeholdere. } \\
\text { Etos } \\
\text { Meritokratiet } \\
\text { Tredje-rolle-rasjonale } \\
\text { Ett middel for å nå forsknings- og } \\
\text { undervisningsmål } \\
\text { Tredje-rolle-suksess } \\
\text { Når det har bidratt til at } \\
\text { forsknings- og undervisningsmål } \\
\text { nås. }\end{array}$ & $\begin{array}{l}\quad \text { Teknokratisk arena } \\
\text { Maktbase } \\
\text { Ekstern } \\
\text { Lederskap (suksess) } \\
\text { Evne til å finne instrumentelle } \\
\text { kompromisser mellom eksterne } \\
\text { stakeholdere. } \\
\text { Etos } \\
\text { Byråkratiet } \\
\text { Tredje-rolle-rasjonale } \\
\text { Oppfylle eksterne forventninger } \\
\text { og krav } \\
\text { Tredje-rolle-suksess } \\
\text { Effektivitet og skala i leveranser }\end{array}$ \\
\hline $\begin{array}{l}\text { Institusjonell } \\
\text { (verdi rasjonell) }\end{array}$ & $\begin{array}{l}\quad \text { Deliberativ arena } \\
\text { Maktbase } \\
\text { Det gode argumentet i åpen debatt } \\
\text { Lederskap (suksess) } \\
\text { Åpent, etisk og demokratisk } \\
\text { Etos } \\
\text { Egalitarisme } \\
\text { Tredje-rolle-rasjonale } \\
\text { Samarbeid der det er delte mål, } \\
\text { verdier og normer. } \\
\text { Tredje-rolle-suksess } \\
\text { Når utøvelse av denne forsterker } \\
\text { egne normer og verdigrunnlag }\end{array}$ & $\begin{array}{l}\quad \text { Samfunnsarena } \\
\text { Maktbase } \\
\text { Nettverk (sosial kapital) } \\
\text { Lederskap (suksess) } \\
\text { Evne til å forhandle frem aksiolo- } \\
\text { giske kompromisser } \\
\text { Etos } \\
\text { Pragmatisme } \\
\text { Tredje-rolle-rasjonale } \\
\text { En samfunnstjeneste } \\
\text { Tredje-rolle-suksess } \\
\text { Eksterne aktører og institusjoner } \\
\text { myndiggjøres og lykkes med å nå } \\
\text { egne mål. }\end{array}$ \\
\hline
\end{tabular}

Figur 1. Universiteters governance og autonomi, tilpasset fra Pinheiro og Normann (2018).

Den siste modellen, universitetet som en samfunnsarena (civic), bygger på John Goddard og hans kollegaers arbeider (Goddard et al., 2016). I denne modellen stammer makt fra evnen til å bygge nettverk og 
relasjoner (sosial kapital) til eksterne parter og å være lydhør overfor disse partenes mål, strategier og visjoner. Det er fortsatt slik at universitetet er styrt av sine egne normer og verdier, men i denne modellen evner man å gjøre en pragmatisk tilpasning av egne normer til eksterne behov. Lederskapets suksess blir i denne modellen derfor en funksjon av evnen til å forhandle frem aksiologiske kompromisser mellom parter som er både interne og eksterne til universitetet (Pellizzoni, 2001). Motivene for samarbeid med eksterne aktører vil i denne modellen være knyttet til at universitetet har et engasjement og en norm om å være en samfunnsaktør som skal bidra til å utvikle det samfunnet det er en del av. Suksess i tredje-rolle-utøvelse vil derfor bli målt ut ifra i hvilken grad eksterne aktører lykkes med å nå egne mål.

I typologien som følger av dette, illustrert ved figuren over, får den tredje rollen et noe ulikt innhold avhengig av om vi forstår universitetet som en strategisk, teknokratisk eller en deliberativ arena eller som en samfunnsarena. Typologien er å forstå som et verktøy for å tolke et empirisk fenomen, og ikke forenklinger av en empirisk beskrivelse.

\section{Den tredje rollen i praksis}

Utviklingen av tredje-rolle-strategier ved de nye universitetene har fulgt et relativt forutsigbart mønster gitt den nasjonale politikk og de retningslinjer som til enhver tid har eksistert. Den offentlige politikken knyttet til utøvelse av den tredje rollen kan noe forenklet deles inn i tre tidsperioder. Før 1970, mellom 1970 og 1995, og etter 1995. Før 1970 var disse institusjonene å forstå som utdanningsinstitusjoner. Eksterne engasjementer og forskning var verken forventet eller ønsket i noen utstrekning. Etter 1970 og frem til 1995 skjer det en oppmykning, der forskning ble akseptert, men hovedsakelig begrenset til noen mindre ressurskrevende disipliner som ble definert av myndighetene. Etter 1995 ble det lovpålagt at alle aktiviteter som universitetene bedriver, skal være forskningsbaserte. Disse endringene har med andre ord viktige implikasjoner for hvordan den tredje rollen har blitt tolket og operasjonalisert. I det videre gir vi noen eksempler på dette, der vi deler utviklingen av den tredje rolle inn i fire faser. 


\subsection{Fase 1: Den tredje rollen som undervisningsrollen}

Før høgskolereformen i 1994 fungerte de statlige høgskolene og i særlig grad distriktshøgskolene som rene undervisningsinstitusjoner. Svært lite forskning ble gjort, og lite eksternt rettet arbeid, slik vi ofte i dag kjenner den tredje rollen, ble utført. Disse undervisningsinstitusjonene utførte hva vi kan forstå som en samfunnsutviklerrolle gjennom å desentralisere utdanning og bidra til at alle regioner, selv utkantene, fikk tilgang på kompetent arbeidskraft. Eksempler på utdanninger som ble tilbudt, er lærerutdanninger, sykepleier- og andre helsefaglige utdanninger foruten medisinerutdanning, ingeniørutdanninger og økonomiutdanninger.

\subsection{Fase 2: Den tredje rollen som regional mobilisering}

Etter at høgskolereformen i 1994 ble gjennomført, har mange av de nye høgskolene fått en størrelse som gjør at mange av dem kommer i samme liga som de allerede etablerte universitetene når det gjelder studentvolum og antall ansatte. Ambisjonen om å ta steget fra høgskole til universitet dukket derfor raskt opp mange steder i landet. En utfordring som man raskt møtte, var at verken de etablerte universitetene eller regjeringen uttrykte ønske om å støtte en slik utvikling. Denne utviklingen falt i tid sammen med en internasjonal regionaliseringsbølge som også satte spor i norsk politikk (Normann, 2007). Regionale partnerskap dukket etter hvert opp over hele landet, og felles for flere av dem er at å gjøre den lokale høgskolen om til universitet ble en sentral og samlende strategi. NOKUTs konkrete kriterier som synliggjorde objektive mål på hva som var forskjellen på en høgskole og et universitet, ble samtidig et veikart for de regionale partnerskapene. De regionene som også klarte å frigjøre økonomiske ressurser, midler man fikk direkte fra en motvillig stat, ble ledende i toget mot universitetsstatus. I Norge var det Rogaland og Agder som, ved å frigjøre midler fra kommunale eierskap i vannkraft, ledet an i denne utviklingen (Hidle \& Normann, 2013). Den tredje rollen ble i disse regionene og i denne fasen synonymt med et altoverskyggende regionalt utviklingsprosjekt om å gjøre høgskolen om til universitet. 


\subsection{Fase 3: Den tredje rollen som eksperimentering}

Universitetsstatus ble oppnådd for Norges miljø- og biovitenskapelige universitet (NMBU) i 2004, for Universitetet i Stavanger (UiS) i 2004, for Universitetet i Agder (UiA) i 2007, for Nord universitet i $2012^{4}$ og for Universitetet i Sørøst-Norge (USN) og OsloMet i 2018. De nye universitetene som hadde oppnådd universitetsstatus gjennom en langvarig og bred regional mobilisering, hadde i de første årene etter at universitetsstatus var sikret, en fase preget av søken etter hvordan man skulle utforme den tredje rollen. På Agder hadde man for eksempel lansert ideen om det regionale universitetet, annerledesuniversitetet (Karlsen, 2007). Forventningene til hva det nye universitetet skulle bidra med, og det raskt, var store i regionen. Det som likevel skjedde, var at alle høgskolene som ble universiteter, mest fokuserte på interne prosesser og utvikling. Flere hadde blitt universitet ved mye politisk drahjelp, støtte og velvilje. Selv om kriteriene objektivt sett var møtt, sto de overfor en omfattende jobb med å oppgradere de administrative, de faglige og de studentorienterte sidene av organisasjonene. Man så nå utover landegrensene i større grad, og man sammenlignet seg med institusjoner som ofte hadde hatt mange tiår og i mange tilfeller flere århundrer med institusjonell utvikling. Hvis vi ser på strategidokumenter som er utformet i denne perioden, gjenspeiler de en spredning i mål. Man skal gjerne være nasjonalt og internasjonalt ledende på noen felt, ha prominente fagmiljøer, tiltrekke seg nasjonale og internasjonale forskningsmidler, være innovative i bruk av nye undervisningsformer og teknologier, samtidig som man skal fortsette å samarbeide tett med regionale aktører og være sentral i å bidra til å ivareta deres utviklings- og forskningsbehov (Universitetet i Agder, 2009).

Det at vi beskriver den tredje rollen i denne fasen som en eksperimenteringsfase, skyldes at det blir tatt mange nye initiativer, både fra ledelsen og fra fagmiljøene. Universitetet får også mange kontakter i sine nære omgivelser og får etter hvert også tilskrevet rollen med å styre FoU-institusjoner i sin randsone og i det regionale innovasjonssystemet (Normann \& Johnsen, 2011). For universitetets ledelse blir det en nesten uoverkommelig oppgave å forholde seg til dette på et strategisk nivå,

Universitetet i Nordland 
samtidig som man skal vurdere potensialet og verdien i de ulike samarbeidene. Senere blir dette forenklet ved at man heller enn å ha direkte dialog med enkeltbedrifter inngår i strategiske samarbeid med klyngeorganisasjoner i regionene. Dette gjør at universitetene i mindre grad enn tidligere forholder seg direkte til enkeltbedrifter. Dette reduserer kompleksitet, men reduserer også universitetets oppmerksomhet om enkeltaktørers utviklings- og forskningsbehov.

\subsection{Fase 4: Den tredje rolle som eksellens i forskning}

Det store arbeidet som de nye universitetene tok fatt på etter at de hadde fått universitetsstatus, var på mange måter usynlig for deres nære omgivelser. Det handlet om å profesjonalisere organisasjonen og øke kvalitet i alle ledd av virksomheten. For de faglig ansatte så man at rene undervisningsstillinger ble sjeldnere, og at forskning ble vektlagt mer. Nasjonale og internasjonale sammenligninger av de nye universitetene og de gamle viste at forskjellen mellom institusjonene i hovedsak nå kunne tilskrives én dimensjon, omfang og kvalitet på den eksterne forskningsfinansieringen. Dette var særlig knyttet til å være med på eller være vert for nasjonale forskningssentre som Sentre for forskningsdrevet innovasjon (SFI), Forskningssentre for miljøvennlig energi (FME) og Sentre for fremragende forskning (SFF), noe som nesten utelukkende i denne perioden var forbeholdt de gamle universitetene i Oslo, Trondheim og Bergen. En annen type prestisjefull kilde til forskningsfinansiering var knyttet til deltakelse i ulike europeiske rammeprogrammer for forskning. Deltakelse i denne type av forskning krever humankapital, men den krever også ofte dyr infrastruktur, og den krever ikke minst brukerpartnere. Disse brukerpartnerne skal gjerne være store nasjonale og/eller internasjonale virksomheter. Universitetene kunne igjen utnytte mulighetsrommet i regionale samarbeid for å realisere samarbeidsprosjekter. Tidligere hadde dette samarbeidet i stor grad skjedd ved bruk av offentlig-private partnerskap. Nå brukte man klyngeorganisasjonene og deres politiske nettverk og innflytelse for å sikre tilgang på infrastruktur. Dette var en strategi som lyktes både for Universitetet i Stavanger og for Universitetet i Agder, hvor sistnevnte fikk gjort betydelige 
investeringer i teknologisk infrastruktur knyttet til robotikk. Universitetet i Stavanger (med Senter for boring, brønnteknologi og utvinning) og Universitetet i Agder (med Offshore Mechatronics) ble også vertskap for egne SFI-prosjekter. Ingen av disse prestisjefylte prosjekttildelingene eller infrastruktur-investeringene ville ha vært mulig uten at disse institusjonene også aktivt gjorde bruk av sitt tredje-rolle-mandat og sitt samarbeid med andre FoU-miljøer, slik som IRIS i Rogaland og Teknova i Agder (begge er nå NORCE).

\section{Konklusjon}

I starten av dette kapitlet stilte vi spørsmålet om hva som kjennetegner utviklingen av den tredje rollen når distriktshøgskolen blir universitet. Vi vil være forsiktige med generalisering av funn samt med å oversette en teoretisk typologi inn i en empirisk kontekst. Vi mener likevel at diskusjonen er illustrativ og kan brukes til å diskutere mekanismer og dynamikk knyttet til universitetets livssykluser og kritiske overganger knyttet til styring av den tredje rollen innenfor ulike regimer. En forsiktig antydning av hvordan den tredje rollen har utviklet seg, vil derfor, med de nevnte forbehold, ta utgangspunkt i en stilisert forenkling av empirien. Vel vitende om at alle institusjoner er komplekse enheter med mange og ofte motstridene strømminger, noe som igjen muliggjør ulike typer av beskrivelser.

Hvis vi likevel skal gjøre en slik øvelse, vil vi si at i fase 1 , når universitetet fremdeles er en distriktshøgskole som i all hovedsak gjennomfører ulike typer av profesjonsutdanninger, er å forstå som et meritokrati styrt av interne prosesser med hovedmål om å gi god utdanning til flest mulig. I denne fasen er forskning som funksjon svakt institusjonalisert, og relasjonen med og legitimitet blant de eksterne aktørene er basert på å håndtere behovene fra regionale aktører når det gjelder kompetanse og vekst. Det skjer en betydelig endring i både omfang og skala på eksternt samarbeid når høgskolene begynner på overgangen til å bli universiteter. I denne fasen foregår det en konvergens av visjoner og mål blant interne og eksterne aktører, der disse spiller en kritisk rolle i å skape betingelsene for endring, både legale og legitime. Agder og Rogaland er eksempler på 
regioner som på et tidspunkt lyktes med å kople interne og eksterne mål til felles handling (Hidle \& Normann, 2013; Normann et al., 2013). Vi tilskriver denne fasen å kjennetegnes ved vår beskrivelse av universitetet som en deliberativ arena. Etter at universitetsstatus er sikret, kommer vi til det vi har kalt en eksperimenteringsfase. Mange initiativer som kan tilskrives den tredje rollen, tas både internt og eksternt. Universitetet har en pragmatisk, nærmest en entreprenøriell, tilnærming, basert på utviklingen av universitetet som en samfunnsarena der ulike perspektiver og muligheter konkurrerer om oppmerksomhet, og får mulighet til å spille seg ut. Denne tredje fasen er i våre eksempler relativt kortvarig, og i takt med at universitetet profesjonaliseres og institusjonaliseres, går man raskt inn i en ny rolle. I denne fasen blir den tredje rollen på mange måter gjenopplivet ved at den blir sentral for å realisere andre mål knyttet til forskning og for å øke nasjonal og internasjonal profilering. Ofte setter man seg ambisiøse mål som krever at man inngår i samarbeid med tunge, eksterne partnere i privat og offentlig sektor for å lykkes. Hvis vi følger vår typologi, beveger universitetet seg nå tilbake mot å bli eksternt orientert og får en del trekk lik de vi fant da vi beskrev en teknokratisk arena der universitetet kan betraktes som en mekanisme, et instrument, for å nå andre mål.

Dette betyr også at noen nye dilemmaer dukker opp, blant annet rundt akademisk frihet/autonomi og faren for kooptering, slik det først ble definert av Selznick (1984 [1949]) på 1940- og 50-tallet. Det handler derfor om å finne en god balanse mellom interne ambisjoner og eksterne forventninger fra en rekke interessenter som befinner seg på ulike geografiske skalaer (lokalt, regionalt, nasjonalt og globalt) og innenfor ulike sfærer med ulik grad av legitimitet og ekstern kontroll. Vi vurderer det som meningsfullt å betrakte universitetets funksjoner og aktiviteter som åpne systemer knyttet til ekstern dynamikk og imperativ for handling. Likevel betyr ikke dette at universiteter kun er reaktive. De har også potensial til å være proaktive endringsagenter som kan forme strategisk respons med utgangspunkt i både eksterne krav og interne dynamikker og logikker. I hvilken grad og i hvilket omfang universiteter blir reaktive eller proaktive, handler både om ledelse og om de muligheter som ligger i institusjonens kontekst. 


\subsection{Hvor går veien videre?}

Universiteter verden rundt føler sterk press for å være relevante i sosiale, økonomiske, politiske og kulturelle kontekster i endring. Samtidig vil de gå foran og skape ny kunnskap og være en del av den internasjonale kunnskapseliten. Dette er krevende for alle og spesielt for nye universiteter, som har hatt lite tid til å etablere seg som forskningsinstitusjoner og som selvstendige og globale kunnskapsaktører. Nøkkelen er, som drøftet tidligere, å finne en balanse mellom instrumentelle og institusjonelle tilnærminger og identifisere og skape synergier mellom akademiske mål og de mål eksterne aktører setter. Momentum mot tverrfaglig utdanning og forskning og fokus på samhandling og samskaping med eksterne aktører gir nye muligheter til både universiteter og regionale aktører. En meningsfull tredje rolle kan da ideelt bygge på at regionale aktører klarer å skape felles forståelser av problembeskrivelser, løsninger og strategier. Hvis man også klarer å fullføre sirkelen ved å kople dette strategisk og praktisk på et institusjonsnivå hos universitetet, kan dette være grunnlaget for en bærekraftig og kraftfull konfigurasjon av den tredje rollen. Det finnes i Norden flere regioner og universiteter som har lyktes med dette, og vi har i dette kapitlet sett på noen eksempler. Den tredje rollen er kommet for å bli. Spørsmålet er om den skal fortsette å være vag og uklar eller operasjonalisert på en slik måte at den bidrar til å skape både god forskning, undervisning og FoU-aktiviteter som kan være med og utvikle robuste, bærekraftige og utviklingsorienterte regioner.

Det vil fremover være behov for mer forskning på dette området $\mathrm{i}$ takt med at behov for mer forståelse av disse komplekse dynamikkene øker. Universiteter må for å være relevante eksistere i takt med samfunnet rundt seg. Samfunnet endrer seg, og det endrer seg tilsynelatende bare raskere og raskere i takt med endringer innenfor teknologi, kultur, migrasjon, miljø, helse, klima mv. Løsninger på nye utfordringer vil kunne finnes i situasjoner der gamle og nye innsikter koples i samspill mellom ulike aktører og kunnskapsbaser. Hvordan universitetene løser sin tredje-rolle, griper derfor også direkte inn i hvordan vi som samfunn løser og svarer på de store samfunnsspørsmålene og utfordringene. 


\section{Referanser}

Amin, A. \& Thrift, N. (1995). Globalisation, 'institutional thickness' and the local economy. I P. Healey, S. Cameron, S. Davoudi, S. Graham \& A. Madanipour (Red.), Managing cities: The new urban context (s. 91-108). Chichester: John Wiley.

Becher, T. \& Trowler, P. (2001). Academic tribes and territories: Intellectual enquiry and the culture of disciplines. Buckingham: Society for Research into Higher Education \& Open University Press.

Benneworth, P., Pinheiro, R. \& Karlsen, J. (2017). Strategic agency and institutional change: Investigating the role of universities in regional innovation systems (RISs). Regional Studies, 51(2), 235-248. https://doi.org/10.1080/00343404.2016.1215599

Bleiklie, I., Høstaker, R. \& Vabø, A. (2000). Policy and practices in higher education: Reforming Norwegian universities. London: Jessica-Kingsley.

Castells, M. (2001). Universities as dynamic systems of contradictory functions. Challenges of globalisation. South African debates with Manuel Castells (s. 206-233). Cape Town: Maskew Miller Longman.

Chatterton, P. \& Goddard, J. (2000). The response of higher education institutions to regional needs. European Journal of Education, 35 (4), 475-496. https://doi. org/10.1111/1467-3435.00041

Christy, R. D. \& Williamson, L. (1992). A century of service: Land-grant colleges and universities, 1890-1990. London: Routledge.

Enders, J. \& Boer, H. (2009). The mission impossible of the European university: Institutional confusion and nstitutional diversity. I A. Amaral, G. Neave, C. Musselin \& P. Maassen (Red.), European integration and the governance of higher education and esearch (s. 159-178). Netherlands: Springer.

Goddard, J. (1997). Managing the university/regional interface. Higher Education Management, 9(3), 7-28.

Goddard, J., Hazelkorn, E., Kempton, L. \& Vallance, P. (Red.). (2016). The civic university: The policy and leadership challenges. Cheltenham: Edward Elgar.

Goddard, J. \& Puukka, J. (2008). The engagement of higher education insitutions in regional development: An overview of the opportunities and challenges. Higher Education Management and Policy, 20(2), 3-33.

Gulbrandsen, M. \& Nerdrum, L. (2009). University-industry relations in Norway. I J. Fagerberg, D. C. Mowery, \& B. Verspagen (Red.), Innovation, path dependency and policy - the Norwegian case (s. 297-326). Oxford: Oxford University Press.

Harding, A., Scott, A., Laske, A. \& Burtscher, C. (Red.). (2007). Bright satanic mills: Universities, regional development and the knowledge economy. Aldershot: Ashgate.

Hidle, K. \& Normann, R. (2013). Who can govern? Comparing network governance leadership in two Norwegian city-regions. European Planning Studies, 21(2), 115-13o. https://doi.org/10.108o/o9654313.2012.722924 
Johnsen, H. C. G., Normann, R. \& Pinheiro, R. (2017). Universities' external relations. I H. C. G. Johnsen, E. S. Hauge, M.-L. Magnussen \& J. R. Ennals (Red.), Applied social science research in a regional knowledge system: Balancing validity, meaning and convenience (s. 274-286). Abingdon: Routledge.

Karlsen, J. (2007). The regional role of the university (Doktoravhandling). Trondheim: Norwegian University of Science and Technology.

Kirke- og undervisningsdepartementet. (1968). Om prøvedrift med distriktshøgskoler (Prop. 136 1968-1969). Oslo: Kirke- og undervisningsdepartementet.

Kirke- og undervisningsdepartementet. (1969). Innstilling om utvida prøvedrift med distriktshøgskoler (Innst. 249 1969-1970). Oslo: Kirke- og undervisningsdepartementet.

Kyvik, S. (1981). The Norwegian regional colleges: A study of the establishment and implementation of a reform in higher education. Oslo: Norwegian Research Council for Science and the Humanities.

Kyvik, S. (2002). The merger of non-university colleges in Norway. Higher Education, 44(1), 53-72. https://doi.org/10.1023/a:1015561027230

Levin, M. \& Greenwood, D. J. (2016). Creating a new public university and reviving democracy. Action research in higher education. New York: Berghahn.

March, J. G. \& Olsen, J. P. (1989). Rediscovering institutions: The organizational basis of politics. New York: Free Press.

March, J. G. \& Olsen, J. P. (1995). Democratic governance. New York: The Free Press.

March, J. G. \& Olsen, J. P. (1998). The institutional dynamics of international political order. International Organization, 52, 943-969.

Merton, R. K. (1973). The sociology of science. Theoretical and empirical investigations. Chicago: University of Chicago Press.

Normann, R. (2007). Democracy in development - a critical view on regional governance (Doktoravhandling). Trondheim: Norwegian University of Science and Technology.

Normann, R., Abelsen, B., Eikeland, S., Farsund, A. A., Fosse, J. K., Hidle, K. \& Kvidal, T. (2013). Regional samhandling for innovasjon. I B. Abelsen, S.-E. Jakobsen, \& A. Isaksen (Red.), Innovasjon - organisasjon, region og politikk (s. 273-322). Oslo: Cappelen Damm Akademisk.

Normann, R. \& Johnsen, H. C. G. (2011). Mulighetsstudie for «Technology Transfer Office»-funksjonen ved Universitetet $i$ Agder - En utredning for Universitetet $i$ Agder. FoU-rapport 3/2011. Kristiansand: Agderforskning.

Normann, R. \& Pinheiro, R. (2018). University collaboration at a cross-road: Evolution and tensions in third-mission engagement. I R. Pinheiro, M. Young \& K. Šima (Red.), Higher education and regional development: Tales from Northern and Central Europe (s. 167-189). Cham, Switzerland: Palgrave Macmillan.

OECD. (2007). Higher education and regions: Globally competitive, locally engaged. Paris: Organisation for Economic Co-operation and Development. 
Olsen, J. P. (2007). The institutional dynamics of the European university. I P. Maassen \& J. P. Olsen (Red.), University dynamics and European integration (s. 25-54). Dordrecht: Springer.

Pellizzoni, L. (2001). The myth of the best argument: Power, deliberation and reason. British Journal of Sociology, 52(1), 59-86. https://doi. org/10.1080/00071310020023037

Pinheiro, R. \& Benneworth, P. (2018). The regional role of higher education. I J. C. Shin \& P. Teixeira (Red.), Encyclopedia of international higher education systems and institutions. Dordrecht: Springer.

Pinheiro, R., Benneworth, P. \& Jones, G. A. (2015). Beyond the obvious: Tensions and volitions surrounding the contributions of universities to regional developmen. I L. Farinha, J. Ferreira, H. Lawton-Smith \& S. Bagchi-Sen (Red.), Handbook of research on global competitive advantage through innovation and entrepreneurship (s. 150-172). Hershey, PA: IGI.

Pinheiro, R., Benneworth, P. \& Jones, G. A. (Red.). (2012). Universities and regional development: A critical assessment of tensions and contradictions. Milton Park and New York: Routledge.

Pinheiro, R., Karlsen, J., Kohoutek, J. \& Young, M. (2017). Universities' third mission: Global discourses and national imperatives. Higher Education Policy, 30 (4), 425-442. https://doi.org/10.1057/s41307-017-0057-5

Pinheiro, R. \& Normann, R. (2018). Designed for regional engagement? The case of Telemark University College. I R. Pinheiro, M. Young \& K. Šima (Red.), Higher education and regional development: Tales from Northern and Central Europe (s. 53-77). Cham, Switzerland: Palgrave Macmillan.

Pinheiro, R., Normann, R. \& Johnsen, H. C. G. (2016). External engagement and the academic heartland: The case of a regionally-embedded university. Science and Public Policy, 43(6), 787-797. https://doi.org/10.1093/scipol/scwo2o

Pinheiro, R., Sima, K., Young, M. \& Kohoutek, J. (2018). University complexity and regional development in the periphery. I R. Pinheiro, M. Young \& K. Sima (Red.), Higher education and regional development: Tales from Northern and Central Europe (s. 53-77). Cham, Switzerland: Palgrave Macmillan.

Pinheiro, R. \& Stensaker, B. (2018). Balancing efficiency and equity in a welfare state setting: High participation higher education in Norway. I B. Cantwell, S. Marginson \& A. Smolentseva (Red.), High participation systems of higher education (s. 386-417). Oxford: Oxford University Press.

Selznick, P. (1984) [1949]. TVA and the grass roots: A study in the sociology of formal organization. Berkeley: University of California Press.

Stensaker, B., Persson, M. \& Pinheiro, R. (2016). When mergers fail: A case study on the critical role of external stakeholders in merger initiatives. European Journal of Higher Education, 16(56-70). 
Universitetet i Agder (2009). Strategi for Universitetet i Agder 2010-2015.

Kristiansand: Universitetet i Agder.

Universitets- og høyskoleloven. (1995). Lov om universiteter og høyskoler (LOV-199505-12-22). Oslo: Kunnskapsdepartementet.

Whyte, W. (2015). Redbrick: A social and architectural history of Britain's civic universities. Oxford: Oxford University Press. 



\title{
Næringslivets samhandling med universiteter og høgskoler i og utenfor regionen: Funn fra en undersøkelse av norske bedrifter
}

\author{
Rune Dahl Fitjar \\ Avdeling for innovasjon, ledelse og markedsføring, Handelshøgskolen \\ ved UiS, Universitetet i Stavanger
}

\section{Utku Ali Rıza Alpaydın}

Avdeling for innovasjon, ledelse og markedsføring, Handelshøgskolen ved UiS, Universitetet i Stavanger

\begin{abstract}
The chapter examines collaboration with universities from the perspective of firms, drawing on survey data from 1200 Norwegian firms. Around one in five firms collaborate with a university. The firms provide various motives for collaborating, including access to knowledge, access to students and staff, and improving their reputation. The collaborations span a wide variety of different mechanisms, including research, teaching and other activities. Frequently used indicators of university-industry interaction, such as joint research projects and contract research, account for less than half of all collaborations, while informal consultations and training or educational programmes emerge as important areas of collaboration. In two-thirds of the cases, the local university is the most important partner for university-industry interaction, while the national technical university NTNU accounts for more than half of the most important inter-regional connections. In total, 93 percent of firms involved in university-industry interaction have connections to their local universities. However, half of them also interact with universities in other regions of Norway, and 30 percent with foreign universities. Hence, local universities can act as bridges that also enable firms to reach distant research groups.
\end{abstract}

Keywords: university-industry collaboration, geography of collaboration, third mission, survey data, Norway

Sitering av dette kapitlet: Fitjar, R. D., \& Alpaydın, U. A. R. (2019). Næringslivets samhandling med universiteter og høgskoler i og utenfor regionen: Funn fra en undersøkelse av norske bedrifter. I J. P. Knudsen \& T. Lauvdal (Red.), Geografi, kunnskap, vitenskap. Den regionale UH-sektorens framvekst og betydning (s. 177-194). Oslo: Cappelen Damm Akademisk. https://doi.org/10.23865/noasp.73.ch7.

Lisens: CC BY 4.0 


\section{Innledning}

Universitetenes tredje oppgave - ved siden av forskning og utdanning er å bidra til innovasjon og samfunnsutvikling (Jongbloed et al., 2008; Göransson et al., 2009). For å oppfylle samfunnskontrakten og rettferdiggjøre offentlig finansiering må universitetene være relevante for samfunnet. Et vesentlig spørsmål i denne sammenheng er hvordan man skal definere «samfunnet» universitetene skal bidra til. Historisk har universitetene forholdt seg til ulike forståelser av samfunnet, blant annet knyttet til ulike geografiske nivåer. De første norske universitetene hadde et nasjonalt oppdrag, med forventninger om at de skulle ivareta funksjoner for hele landet innenfor sine fagområder. Med opprettelsen av Universitetet $\mathrm{i}$ Tromsø og utbyggingen av distriktshøgskoler fra slutten av 1960-tallet fikk vi institusjoner som hadde regionale oppdrag (Vabø \& Aamodt, 2005). Distriktshøgskolene skulle bidra til utviklingen av samfunnet i regionene der de ble etablert. Etter hvert som flere av distriktshøgskolene har fătt universitetsstatus de siste 15 årene, er det uavklart om disse fortsatt har et regionalt oppdrag, eller om de i større grad har nasjonale oppgaver på linje med de klassiske universitetene. Foruten de nasjonale og regionale oppdragene vil nok universitetene selv og deres ansatte fremheve ansvaret for å bidra til utvikling også i større målestokk. Universitetene spiller en viktig rolle i å fremskaffe ny kunnskap for verden, og de deltar i arbeidet med å løse globale utfordringer på en rekke områder. Alle norske universiteter har eksempelvis integrert FNs bærekraftsmål i sine strategier (Aall, 2018).

Samfunnsoppgaven er bred og kan fylles med mange ulike typer innhold (Pinheiro et al., 2015). Den omfatter både universitetenes generelle formidlingsaktivitet rettet mot allmennheten (gjennom foredrag, intervjuer, kronikker osv.), og deres spesifikke bidrag til verdiskaping $\mathrm{i}$ offentlig sektor og i næringslivet. Universitetene kan dessuten bidra til verdiskaping i næringslivet enten direkte gjennom sin egen kommersialiseringsvirksomhet eller indirekte gjennom samhandling med eksisterende bedrifter.

Selv om den tredje oppgaven har et vidt innhold, måles den ofte ved hjelp av et svært begrenset antall indikatorer. Ofte fokuserer både universitetene selv og deres eiere (i norsk sammenheng Kunnskapsdepartementet) særlig på kommersialisering (Perkmann et al., 2013; Stølen \& 178 
Gornitzka, 2017). I Norge rapporterer universitetene årlig antall patenter, lisenser og nye foretak, og de får støtte til denne virksomheten gjennom sine TTO-er. Universitetenes bidrag til eksisterende næringsliv (for ikke å snakke om samfunnet for øvrig) blir i betydelig mindre grad fanget opp. Det er riktignok gode finansieringsordninger for slik virksomhet gjennom Forskningsrådet og særlig SkatteFUNN-ordningen. Også dette omfatter imidlertid bare en liten del av universitetenes totale bidrag til næringslivet, i hovedsak eksternt finansierte forskningsprosjekter for eller med næringslivet. Indikatorer og studier av universitetenes samhandling med næringslivet tar dessuten som regel utgangspunkt i universitetets virksomhet og deres aktiviteter. Vi vet derfor mindre om hvordan næringslivet samhandler med universitetene, med unntak av mer generelle studier av FoU-samarbeid (f.eks. Fitjar \& Rodríguez-Pose, 2013; Haus-Reve et al., 2019).

For å kartlegge dette fenomenet fra næringslivets perspektiv har vi spurt norske bedrifter om omfanget av, og innholdet $i$, deres samhandling med universitetene. Studien tar for seg et bredt spekter av ulike typer samhandling. Den ser med andre ord ikke bare på forskningssamarbeid og kommersialisering, men også på samarbeid knyttet til utdanning, kompetanseutvikling og samfunnsansvar. Vi har også undersøkt den geografiske dimensjonen i samhandling med universiteter, ved å spørre bedriftene hvilke universiteter de samarbeider med.

I kapitlet presenterer vi først litt bakgrunnskunnskap fra tidligere forskning om samhandling mellom universiteter og næringslivet, med vekt på spørsmålet om i hvilken grad slik samhandling er regional, nasjonal eller internasjonal. Dernest presenterer vi resultater fra undersøkelsen av norske bedrifter. Vi ser særlig på omfanget av samarbeid med universiteter, bedriftenes motiver for å samarbeide, innholdet i samarbeidet, og hvilke universiteter de samarbeider med.

\section{Hva vet vi om samhandling mellom universiteter og næringslivet?}

Det er en stor litteratur om samarbeid mellom universiteter og næringslivet (D'Este \& Patel, 2007; Perkmann \& Walsh, 2007). Mye av denne tar 
utgangspunkt i hvordan næringslivet bruker kunnskap fra universitetene i sitt innovasjonsarbeid. Utviklingen i retning av et mer kunnskapsbasert næringsliv og åpne, nettverksbaserte innovasjonsprosesser har gjort samarbeid med universiteter aktuelt for en større andel av næringslivet. Stadig flere jobber krever høyere utdanning, gjerne på mastergradsnivå, og flere bedrifter driver egen FoU-aktivitet. Dette gjør universitetene til naturlige samarbeidspartnere også for næringslivet.

Samtidig viser innovasjonsundersøkelsene at universitetene kommer langt ned på listen over bedriftenes viktigste samarbeidspartnere. Bare fem prosent av virksomhetene med innovasjonssamarbeid i 2014-2016 regnet et universitet eller en høgskole som sin viktigste samarbeidspartner. Leverandører, kunder og også konsulenter kommer betydelig høyere opp på lista (Statistisk sentralbyrå, 2017). Selv om få bedrifter vurderer universitetene som sin viktigste partner, er det likevel mye som tyder på at både omfanget av universitetssamarbeid og betydningen av slikt samarbeid for innovasjon er betydelig (Howells et al., 2012). Bedrifter som samarbeider med universiteter, viser seg eksempelvis å innovere i større grad enn de som ikke gjør det (Fitjar \& RodríguezPose, 2013).

Samarbeid mellom universiteter og næringslivet er ofte krevende. På mange måter opererer de to aktørene i to ulike verdener, med ulike prioriteringer og institusjonelle rammebetingelser (Hewitt-Dundas et al., 2019). Litt forenklet kan vi si at universitetene forsøker å gjøre penger om til ny kunnskap, mens bedriftene forsøker å gjøre ny kunnskap om til penger. For universitetene er kunnskap et offentlig gode. I næringslivet har innovasjon i seg selv ingen verdi, med mindre det skaper inntekter eller reduserer kostnader for bedriften. Det fører til at universitetene typisk vil publisere resultater fra samarbeidsprosjekter i internasjonale tidsskrift, mens bedriftene gjerne ønsker å holde resultatene hemmelige eller sikre seg intellektuell eiendomsrett over dem i form av patenter. Forskning som er publisert, kan ikke patenteres og har ofte liten kommersiell verdi for en bedrift. Motsatt måles forskernes vitenskapelige produktivitet i publikasjoner, mens patenter og bidrag til verdiskaping i næringslivet i liten grad er meritterende. Universitetene har dessuten gjerne lang tidshorisont og tilstreber robuste og etterrettelige analyser, mens bedriftene er på jakt 
etter løsninger som er gode nok og fungerer her og nå. Universitetene vektlegger gjerne grunnforskning og abstrakte modeller, mens bedriftene er opptatt av hvordan kunnskapen kan anvendes i praksis. På toppen av dette kommer at universiteter gjerne er store og byråkratiske organisasjoner. De kan være vanskelige å forholde seg til, særlig for små bedrifter (Bruneel et al., 2010).

Universitetene møter i økende grad forventninger om at de skal bidra til næringslivet. Dagens universiteter skal være entreprenørielle (Clark, 1998), samfunnsengasjerte (Breznitz \& Feldman, 2012) og aktive i trippel-helix-samarbeid med næringsliv og myndigheter (Etzkowitz \& Leydesdorf, 2000). De forsøker dermed aktivt å gjøre det lettere for bedriftene å bruke universitetets kompetanse. Paradoksalt nok kan imidlertid universitetenes entreprenørielle ambisjoner også skape nye barrierer for samarbeid. Når universitetene selv har ambisjoner om å kommersialisere egen forskning, kan det eksempelvis oppstå konflikter omkring intellektuell eiendomsrett til resultatene av felles prosjekter (Gjelsvik \& Fitjar, 2016).

Mye av litteraturen om universitetenes bidrag til næringslivet undersøker kommersialisering og felles forsknings- og innovasjonsprosjekter. Universitetene samarbeider imidlertid med næringslivet gjennom en rekke kanaler. D'Este og Patel (2007) fant at 65 prosent av forskerne ved britiske universiteter hadde vært involvert i møter eller konferanser med næringslivet de siste to årene, 56 prosent hadde deltatt i konsulentarbeid eller kontraktsforskning, og 45 prosent i felles forskningsprosjekter. Disse aktivitetene var alle langt vanligere enn patentering og kommersialisering av forskning, som bare 25 prosent av forskerne hadde deltatt $i$.

Den geografiske dimensjonen i samarbeid mellom universiteter og næringslivet er et hyppig tema for forskning. Bakgrunnen for dette er studier som viser at universiteter bidrar til å øke verdiskapingen i regionene der de ligger (Jaffe, 1989; Audretsch \& Feldman, 1996). Samarbeid mellom universiteter og næringslivet skjer i stor grad også lokalt. Ifølge Mansfield og Lee (1996) går mellom 55 og 63 prosent av amerikanske bedrifters forskningsmidler til universiteter som ligger innenfor en radius på 100 engelske mil fra bedriften. Tilsvarende studier i Storbritannia 
(D’Este \& Iammarino, 2010) og Brasil (Garcia et al., 2015) har funnet at over halvparten av universitetssamarbeid skjer innenfor en avstand på 80-150 kilometer fra bedriften. Også i Norge skjer bedriftenes innovasjonssamarbeid med universiteter i hovedsak innenfor regionen (Fitjar \& Rodríguez-Pose, 2013).

Dette kan skyldes at geografisk nærhet bidrar til mer effektiv kunnskapsoverføring (Gertler, 2003; Storper \& Venables, 2004). Bedrifter som har behov for å samarbeide med universiteter, lokaliserer seg derfor ofte i nærheten av dem (Audretsch et al., 2005; Woodward et al., 2006; Abramovsky \& Simpson, 2011). Når bedrifter utvikler samarbeid med universiteter utenfor lokalområdet, oppretter de gjerne kontakt med ledende forskningsintensive universiteter. Dermed kan man anta at bedriftene foretar avveininger mellom nærhet til universitetene og tilgang til de fremste forskerne (Laursen et al., 2011; D’Este et al., 2013).

Det kan imidlertid også være andre årsaker til at bedrifter som regel samarbeider med universiteter i regionen (Fitjar \& Gjelsvik, 2018). For det første leter mange bedrifter lokalt etter aktuelle partnere før de eventuelt utvider søket til å vurdere andre universiteter. De kjenner ofte forskere ved det lokale universitetet personlig eller har andre kanaler for å komme i kontakt med dem. De fleste bedrifter er ikke nødvendigvis på jakt etter verdens fremste forskere på sitt felt, men leter etter noen som har tilstrekkelig kompetanse på et område. For det andre er det lokale universitetet en potensielt langsiktig partner for bedriftene. Det gjør at bedriftene kan finne det formålstjenlig å bidra til utvikling av det lokale universitetet, for selv å dra nytte av et styrket universitet på lengre sikt. For det tredje ser bedrifter tidvis også på samarbeid med universitetet som en måte å utøve samfunnsansvar på. Dette kan ta form av ren sponsing av universitetets virksomhet, bidrag til stipendiatstillinger eller gaveprofessorater. Det kan imidlertid også ta andre former. Universitetene trenger for eksempel ofte bedriftspartnere for å søke om eksternt finansierte prosjekter, for eksempel fra Forskningsrådet. Disse kan være viktigere for universitetet enn for bedriftene, ettersom universitetene i større grad er avhengige av ekstern finansiering. Noen bedrifter er likevel positive til å delta i slike prosjekter for å støtte opp om universitetet. 


\section{Undersøkelse av bedrifter i norske universitetsregioner}

Høsten 2018 gjennomførte vi en spørreundersøkelse om universitetssamarbeid blant bedrifter i norske universitetsregioner. Undersøkelsen omfattet alle bedrifter med fem eller flere ansatte i Oslo, Akershus, Austog Vest-Agder, Rogaland, Hordaland, Trøndelag, Nordland og Troms innenfor sektorene bergverksdrift og utvinning, industri, engroshandel og kunnskapsintensiv tjenesteyting ${ }^{1}$. Totalt gjennomførte vi 1200 intervjuer, med en svarprosent på 12 blant 10117 kontaktede bedrifter. Undersøkelsen ble gjennomført over telefon av profesjonelle intervjuere fra Ipsos. Respondentene var ledere for forskning, utvikling og innovasjon, subsidiært daglige ledere eller ledere med ansvar for samarbeid, rekruttering eller HR.

\section{Hvor mange bedrifter samarbeider med universitetene?}

I alt oppga 232 (19,3 prosent) av de 1200 bedriftene at de hadde hatt kontakt med universiteter eller høgskoler de siste tre årene. Det er altså et mindretall av bedriftene som har kontakt med universiteter eller høgskoler.

\begin{tabular}{|l|c|c|}
\hline & Antall & Prosent \\
\hline Har hatt kontakt & 232 & 19,3 \\
\hline Har ikke hatt kontakt & 968 & 80,7 \\
\hline Totalt & 1200 & 100 \\
\hline
\end{tabular}

Tabell 1. Næringslivets kontakt med universiteter eller høgskoler de siste tre årene.

Bedriftene har ulike motiver for å samarbeide med universiteter. Vi ba de bedriftene som har samarbeid, om å ta stilling til betydningen av en rekke motiver for at de deltar i slikt samarbeid. Tabell 2 viser de gjennomsnittlige svarene på en fempunktskala fra helt uenig til helt enig.

1 Dette omfatter informasjon og kommunikasjon, finansiering og forsikring, faglig, vitenskapelig og teknisk tjenesteyting, samt forretningsmessig tjenesteyting. 
Den viktigste årsaken til at bedrifter samarbeider med universiteter, er for å få tilgang til studenter og ansatte ved universitetene. 61 prosent sier seg helt enige i denne påstanden. Tilgang til ny kunnskap er også et viktig motiv. 52 prosent av bedriftene er helt enige $i$ at de samarbeider med universiteter fordi de ønsker tilgang til ny kunnskap. Videre er 38 prosent helt enige i at de ønsker å forbedre ferdighetene til sine ansatte.

Samarbeid med universiteter handler imidlertid ikke bare om kunnskap. En stor andel av bedriftene peker også på omdømmemessige hensyn som viktige. Totalt er 41 prosent av bedriftene helt enige i at de samhandler med universiteter fordi de ønsker å styrke sitt image eller prestisje. 47 prosent sier seg også helt enige i at samhandlingen er knyttet til at de ønsker å løse samfunnsmessige utfordringer på en bedre måte.

Mindre viktig er det å skaffe tilgang til finansiering. 47 prosent av bedriftene er helt uenige i at dette er en årsak til å samhandle med universitetet, mens bare 20 prosent er helt enige. Et mindretall knytter også samarbeidet til bruk av FoU-fasiliteter. Her er 31 prosent helt uenige i påstanden, mens nesten like mange - 27 prosent - er helt enige.

Tabell 2. Bedriftenes motiver for å samarbeide med universiteter.

\begin{tabular}{|l|c|}
\hline & Gjennomsnitt \\
\hline Vi ønsker tilgang til ny kunnskap. & 4,0 \\
\hline $\begin{array}{l}\text { Vi ønsker å forbedre ferdighetene til våre ansatte eller utvikle personalets } \\
\text { kapasitet. }\end{array}$ & 3,6 \\
\hline Vi ønsker tilgang til FoU-fasiliteter. & 3,0 \\
\hline Vi ønsker tilgang til studenter og ansatte ved universitetet. & 4,3 \\
\hline Vi ønsker å skaffe finansiering eller finansielle ressurser. & 2,5 \\
\hline Vi ønsker å løse samfunnsmessige utfordringer på en bedre måte. & 3,9 \\
\hline Vi ønsker å styrke imaget, prestisjen og omdømmet vårt. & 3,8 \\
\hline$N$ & 216 \\
\hline
\end{tabular}

Merk: Skala fra 1 til 5, der 1 er helt uenig og 5 er helt enig.

\section{Hva samarbeider bedrifter med universitetene om?}

Samarbeid mellom universiteter og næringslivet skjer gjennom en rekke ulike kanaler. Eksisterende indikatorer for slikt samarbeid fanger 
imidlertid bare opp noen få av disse. Dermed har vi forholdsvis lite systematisk kunnskap om hvor omfattende ulike typer samarbeid er. Kunnskapsdepartementets store årlige tilstandsrapport for høyere utdanning ser eksempelvis på nærings-ph.d. og på universitetets egen kommersialiseringsvirksomhet, gjennom patenter, lisenser og etablering av nye foretak. Innovasjonsundersøkelsen er begrenset til kjøp av FoU-tjenester og til FoU-samarbeid, forstått som aktiv deltakelse i felles FoU-aktiviteter. NIFUs indikatorrapport fanger opp flere av disse, og tar også med sampublisering av artikler.

Basert på disse indikatorene konkluderes det ofte med at universitetene er forholdsvis lite viktige for innovasjon i næringslivet. Det er eksempelvis få bedrifter som oppgir å samarbeide med universiteter og høgskoler i sine innovasjonsprosesser, og enda færre som regner disse som sine viktigste samarbeidspartnere.

FoU-samarbeid og kommersialisering utgjør imidlertid kun en liten del av næringslivets samarbeid med universitetene. I bedriftsundersøkelsen har vi sett på utbredelsen av 16 ulike typer samarbeid med universiteter. Tabell 3 viser hvor mange bedrifter som har benyttet seg av hver type som en andel av de bedriftene som har kontakt med et universitet. Svarene viser at samarbeidet fordeler seg på alle typene. Når vi spør om hvilken type som er den dominerende formen for samhandling, fordeler også svarene seg nokså bredt mellom kategoriene, med en modalprosent på så vidt over 20.

Uformelle konsultasjoner er den klart hyppigste formen for kontakt med universitetene. Nesten tre firedeler av de bedriftene som har kontakt med universiteter, bruker uformelle konsultasjoner. Det er relativt få (totalt 7,5 prosent) som regner dette som den viktigste formen for samhandling med universitetet. Like fullt er det en hyppig brukt kanal, som sjelden fanges opp i statistikker over universitetenes næringslivskontakt.

Det er jevnt over noe flere bedrifter som samarbeider med universiteter om undervisning, enn om forskning. To tredeler av bedriftene som har kontakt med universiteter, er involvert i bachelor- eller masterprosjekter, og en av seks mener at dette er den viktigste formen for samhandling. Nesten halvparten deltar i praktikant- eller lærlingordninger for studenter, og omtrent samme andel bidrar til undervisning gjennom 
gjesteforelesninger. I underkant av en tredel har også ordninger knyttet til rekruttering av kandidater. Samme andel samarbeider om opplæring av ansatte eller medarbeidere i bedriften. En forholdsvis høy andel - nesten en av fem bedrifter med universitetskontakt - deltar også i utviklingen av pensum.

På forskningssiden er felles forskningsprosjekter den klart viktigste formen. Flest bedrifter oppgir også dette som den viktigste formen for samhandling med universitetet. Likevel er det bare 45,9 prosent av bedriftene med universitetskontakt som deltar i felles forskningsprosjekter, og drøyt en av fem mener dette er den viktigste formen for samhandling. Det vil si at indikatorer som bare ser på samarbeid gjennom felles forskningsprosjekter, vil fange opp mindre enn halvparten av alle bedrifter som samarbeider med universiteter i ulike former.

Flere andre former for forskningssamarbeid er også hyppig brukt. Rundt en av fire bedrifter med universitetssamarbeid finansierer forskning ved universitetet i form av konsulentarbeid eller oppdragsforskning. En god del av disse oppgir også dette som den dominerende formen for samhandling. Om lag samme andel bruker fasiliteter ved universiteter, som laboratorier eller annet utstyr. En tilsvarende andel deltar i veiledning av ph.d.-stipendiater ved universitetet eller i nærings-ph.d.-ordningen.

Betydelig færre bedrifter er involvert i universitetenes egen kommersialiseringsvirksomhet. Bare 5 prosent av bedrifter som har kontakt med universiteter, har vært involvert i kjøp av patenter, lisenser eller andre immaterielle rettigheter som universitetene har utviklet. Rundt 10 prosent har deltatt $i$ etablering av nye selskaper som springer ut fra universitetet, og rundt 12 prosent har bidratt til infrastruktur knyttet til dette, som inkubatorer eller forskningsparker.

En siste form for samhandling, som også er forholdsvis omfattende, er knyttet til universitetenes bredere samfunnsoppdrag. Rundt en tredel av bedrifter som har kontakt med universitetet, har samarbeidet om felles arrangementer, som konferanser eller seminarer. Rundt en femdel har sponset virksomhet ved universitetet, for eksempel i form av stipender eller stillinger. Det er imidlertid få bedrifter som ser dette som den dominerende formen for samhandling. Slik aktivitet kommer ofte i tillegg til annet samarbeid. 


\begin{tabular}{|c|c|c|c|c|}
\hline \multirow[t]{2}{*}{ Type samhandling } & \multicolumn{2}{|c|}{ Brukt formen } & \multicolumn{2}{|c|}{ Viktigste form } \\
\hline & Antall & Prosent & Antall & Prosent \\
\hline \multicolumn{5}{|l|}{ Forskning } \\
\hline Konsulentoppdrag eller kontraktsforskning & 51 & 22,2 & 16 & 7,1 \\
\hline Felles forskningsprosjekter & 105 & 45,9 & 47 & 20,8 \\
\hline Kjøp av patent, lisens eller annen IP & 12 & 5,3 & - & - \\
\hline Bruk av universitetets fasiliteter, laboratorier, utstyr & 65 & 28,3 & 6 & 2,7 \\
\hline Felles veiledning av ph.d. / nærings-ph.d. & 52 & 23,0 & 4 & 1,8 \\
\hline $\begin{array}{l}\text { Midlertidig utveksling av personale for } \\
\text { forskningsformål }\end{array}$ & 27 & 11,7 & 1 & 0,4 \\
\hline \multicolumn{5}{|l|}{ Undervisning } \\
\hline Opplæring av ansatte & 71 & 30,7 & 9 & 4,0 \\
\hline Praktikant-/lærlingordninger & 107 & 46,5 & 20 & 8,9 \\
\hline Studentprosjekter på bachelor- eller masternivå & 149 & 64,5 & 38 & 16,8 \\
\hline Gjesteforelesninger & 102 & 44,4 & 15 & 6,6 \\
\hline $\begin{array}{l}\text { Rekruttering av kandidater basert på kontrakt eller } \\
\text { henvisning }\end{array}$ & 76 & 32,9 & 13 & 5,8 \\
\hline Felles utvikling av pensum & 42 & 18,4 & 6 & 2,7 \\
\hline \multicolumn{5}{|l|}{ Annet } \\
\hline Uformelle konsultasjoner & 166 & 72,5 & 17 & 7,5 \\
\hline Sponsing, stipend eller stillinger gitt til universitetet & 46 & 20,0 & 3 & 1,3 \\
\hline Felles arrangementer & 74 & 32,3 & 4 & 1,8 \\
\hline Opprettelse av forskningssentre eller inkubatorer & 28 & 12,2 & 1 & 0,4 \\
\hline Opprettelse av nye selskaper & 25 & 10,8 & 1 & 0,4 \\
\hline Annen type samhandling & 80 & 34,6 & 25 & 11,1 \\
\hline
\end{tabular}

Tabell 3. Typer av samhandling med universitetet - andel av bedrifter med universitetskontakt.

\section{Hvilket universitet samarbeider bedriftene med?}

Tabell 4 viser hvilket universitet bedriftene oppgir å ha den mest omfattende samhandlingen med. I overkant av en firedel av bedriftene som har kontakt med universiteter, oppgir NTNU som sin viktigste partner. Antallet bedrifter som samarbeider med NTNU, er mer enn tre ganger høyere enn for noen andre universiteter. Bak NTNU er det ingen av de andre universitetene som skiller seg ut i særlig grad. Andelen bedrifter som samarbeider med universitetene i Oslo, Bergen, Stavanger, Agder, Tromsø og Nord, er nokså like. Det samme gjelder NMBU, 
BI, Høgskulen på Vestlandet og OsloMet. Dersom vi tar i betraktning størrelsen på universitetene og på regionene, er det kanskje noe overraskende at Universitetet i Oslo og Universitetet i Bergen ikke samarbeider med flere bedrifter enn de mindre universitetene. Motsatt skiller Universitetet i Agder seg ut i positiv retning, tatt i betraktning at det ligger $i$ en liten region.

\begin{tabular}{|l|c|c|}
\hline Navn & Antall & Prosent \\
\hline NTNU & 63 & 27,2 \\
\hline UiA & 18 & 7,8 \\
\hline NMBU & 16 & 6,9 \\
\hline UiB & 15 & 6,5 \\
\hline UiS & 15 & 6,5 \\
\hline UiT & 14 & 6,0 \\
\hline Nord & 13 & 5,6 \\
\hline UiO & 10 & 4,3 \\
\hline BI & 10 & 4,3 \\
\hline HVL & 10 & 4,3 \\
\hline OsloMet & 9 & 3,9 \\
\hline Andre & 36 & 15,5 \\
\hline Vet ikke & 3 & 1,3 \\
\hline Totalt & 232 & 100,0 \\
\hline
\end{tabular}

Tabell 4. Mest brukte universitet.

Dette blir enda tydeligere når vi deler opp fordelingen etter hvilken region bedriften ligger i. Tabell 5 viser viktigste universitetspartner etter region. Antallet svar er lavt i mange av regionene, og det er derfor betydelig feilmargin knyttet til andelene for hver enkelt region. Mønsteret er likevel tydelig i alle regionene. Hele 79 prosent av bedriftene i Agder-fylkene oppgir UiA som sin viktigste partner. Dette er høyest av samtlige, også sammenlignet med NTNUs posisjon i Trøndelag (der 70 prosent oppgir NTNU som viktigste partner, mens ytterligere 15 prosent svarer Nord universitet). Gjennomgående samarbeider bedriftene klart mest med universiteter i sin egen region. 53 prosent av bedriftene i Hordaland har UiB som sin viktigste partner, mens 21 prosent fremhever HVL. I Rogaland oppgir 52 prosent av bedriftene UiS som sin viktigste partner, og 10 prosent svarer HVL. I Troms og Nordland er UiT 
den viktigste partneren for 52 prosent av bedriftene, mens Nord universitet er viktigst for 28 prosent. I Oslo og Akershus fordeler svarene seg på flere lokale universiteter: NMBU, UiO, BI og OsloMet. Institusjonene som er oppgitt under «andre», er i stor grad også i egen region, som NHH, Sjøkrigsskolen og Bergen Arkitektskole i Hordaland, og Arkitektur- og designhøgskolen, Politihøgskolen og Westerdals i Oslo/ Akershus.

Det eneste universitetet som i betydelig grad når utover egen region, er NTNU. Med noen få unntak oppgir bedriftene enten sitt lokale universitet eller NTNU som sin viktigste samarbeidspartner. Minst 10 prosent av bedriftene i alle regioner utenom Nord-Norge oppgir NTNU som sin viktigste partner. I Oslo/Akershus svarer mer enn 25 prosent av bedriftene at de har mest omfattende samhandling med NTNU. Dette gjør NTNU til den klart viktigste universitetspartneren for bedrifter i hovedstaden. NTNU er den viktigste partneren for mer enn dobbelt så mange bedrifter som UiO. I de øvrige regionene er det imidlertid betydelig flere som samarbeider med det lokale universitetet enn med NTNU.

\begin{tabular}{|l|r|r|r|r|r|r|r|}
\hline Navn & $\begin{array}{c}\text { Oslo/ } \\
\text { Akershus }\end{array}$ & Agder & Rogaland & Hordaland & Trøndelag & $\begin{array}{c}\text { Troms/ } \\
\text { Nordland }\end{array}$ & Totalt \\
\hline NTNU & 25,3 & 15,8 & 17,2 & 10,7 & 70,0 & 4,0 & 27,2 \\
\hline UiA & 3,3 & 79,0 & - & - & - & - & 7,8 \\
\hline NMBU & 14,3 & - & - & - & 2,5 & 8,0 & 6,9 \\
\hline UiB & 2,2 & - & 3,5 & 52,9 & - & - & 6,5 \\
\hline UiS & - & - & 51,7 & - & - & - & 6,5 \\
\hline UiT & - & - & 3,5 & - & - & 52,0 & 6,0 \\
\hline Nord & - & - & - & - & 15,0 & 28,0 & 5,6 \\
\hline UiO & 11,0 & - & - & - & - & - & 4,3 \\
\hline BI & 8,8 & - & 3,5 & 3,6 & - & - & 4,3 \\
\hline HVL & - & - & 10,3 & 21,4 & 2,5 & - & 4,3 \\
\hline OsloMet & 8,8 & - & - & - & 2,5 & - & 3,9 \\
\hline Andre & 24,2 & 5,3 & 6,9 & 21,4 & 7,5 & 8,0 & 15,5 \\
\hline Vet ikke & 2,2 & - & 3,5 & - & - & - & 1,3 \\
\hline Totalt & 100,0 & 100,0 & 100,0 & 100,0 & 100,0 & 100,0 & 100,0 \\
\hline N & 91 & 19 & 29 & 28 & 40 & 25 & 232 \\
\hline
\end{tabular}

Tabell 5. Mest brukte universitet. Etter region. 
Som dette indikerer, samarbeider bedriftene i all hovedsak med universiteter i sin region. Tabell 6 oppsummerer resultatene for beliggenheten til det viktigste universitetet. To tredeler av bedriftene oppgir et universitet eller en høgskole i regionen som sin viktigste universitetspartner. En tredel oppgir et universitet eller en høgskole et annet sted i Norge som sin viktigste partner. I over halvparten av disse tilfellene gjelder dette samarbeid med NTNU. Bare 3 prosent av bedriftene oppgir et universitet $\mathrm{i}$ utlandet som sin viktigste universitetspartner.

\begin{tabular}{|c|c|c|}
\hline & Antall & Prosent \\
\hline Samme region & 147 & 66,5 \\
\hline Annet sted i Norge & 68 & 30,8 \\
\hline NTNU & 35 & 15,8 \\
\hline Andre & 33 & 14,9 \\
\hline Utenfor Norge & 6 & 2,7 \\
\hline Totalt & 221 & 100,0 \\
\hline
\end{tabular}

Tabell 6. Beliggenhet viktigste universitet.

I tabell 7 utvider vi analysen til å se på alle universiteter som bedriften har samarbeid med, ikke bare det viktigste. De aller fleste norske bedrifter som samarbeider med et universitet, samarbeider også med sitt lokale universitet. Bare sju prosent har utelukkende samarbeid med universiteter utenfor regionen. Et flertall av bedriftene samarbeider imidlertid med flere universiteter og på ulike skalaer. Over halvparten av bedriftene som samarbeider med universiteter, har også noe samarbeid med universiteter andre steder i Norge. En av fem har samarbeid med universiteter i andre europeiske land, og nesten en av ti med universiteter utenfor Europa. Selv om de aller fleste samarbeider med det lokale universitetet, og et stort flertall regner dette som sin viktigste universitetspartner, har mange bedrifter også samarbeid med universiteter som ligger lenger unna.

\begin{tabular}{|l|c|c|}
\hline & Antall & Prosent \\
\hline Samme region & 216 & 93,1 \\
\hline Annet sted i Norge & 120 & 51,7 \\
\hline Europa utenfor Norge & 49 & 21,1 \\
\hline Utenfor Europa & 21 & 9,1 \\
\hline Totalt & 232 & 100,0 \\
\hline
\end{tabular}

Tabell 7. Andel bedrifter med samarbeid, etter geografi. 


\section{Konklusjon}

Rundt en av fem norske bedrifter samarbeider med universiteter. Disse samarbeidene motiveres av en rekke ulike faktorer. Bedriftene er opptatt av å skaffe seg tilgang på ny kunnskap, men minst like viktig er det å få tilgang til forskere og studenter ved universitetene. Mange bedrifter samarbeider også med universiteter for å bedre sitt omdømme eller bidra til å løse bredere samfunnsutfordringer. Samarbeidene kan også ta mange ulike former. Felles forskningsprosjekter utgjør mindre enn halvparten av samarbeidene, og svært få bedrifter kjøper intellektuell eiendomsrett av universitetene. Det vil si at de mest brukte indikatorene, som i stor grad fanger opp disse to dimensjonene, i betydelig grad undervurderer omfanget av samarbeid mellom universiteter og næringslivet. Bedriftene har omfattende samarbeid med universiteter knyttet til undervisning, blant annet i form av studentprosjekter, gjesteforelesninger, praktikantordninger, rekruttering og videreutdanning. På forskningssiden utgjør konsulentoppdrag og kontraktsforskning en stor del av samarbeidet. Uformelle konsultasjoner er også en svært viktig kanal.

Dette innebærer at universitetene må tenke bredt når det gjelder samarbeid med næringslivet. Bedriftssamarbeid er ikke bare et fenomen som omfatter forskningsprosjekter og kommersialisering. Det omfatter også samarbeid om undervisning og opplæring, både knyttet til studenter og til ansatte i næringslivet. Universitetet har dessuten en viktig rolle som en infrastruktur for alt fra laboratorier til seminarer. Ikke minst er uformelle konsultasjoner en betydelig kilde til ny kunnskap for mange bedrifter, og en type aktivitet som ofte går under radaren.

Samarbeid mellom universiteter og næringslivet foregår i stor grad innenfor nærområdet. De aller fleste bedrifter som samarbeider med et universitet, har kontakt med sitt lokale universitet, og to tredeler regner dette som sin viktigste universitetspartner. Det eneste norske universitetet som i særlig grad når ut til bedrifter utenfor sitt lokalområde, er NTNU. I halvparten av tilfellene der en bedrift har sitt viktigste samarbeid utenfor regionen, er dette med NTNU. Mange bedrifter samarbeider imidlertid med flere universiteter. Over halvparten har samarbeid med et nasjonalt universitet i tillegg til det lokale, og mange har også kontakt 
med universiteter i utlandet. Få regner imidlertid disse som sine viktigste universitetspartnere.

Funnene indikerer at norske universiteter fremdeles i betydelig grad har en regional oppgave som samarbeidspartner for næringslivet i nærmiljøet. De fleste bedrifter går først til universitetet i regionen, og eventuelle samarbeid med universiteter lenger unna kommer som regel i tillegg til dette. For universitetenes del innebærer det at de har gode forutsetninger for å utvikle brede samarbeid med det regionale næringslivet. Samtidig er det viktig at bedriftene hjelpes til å komme i kontakt også med universiteter og forskningsmiljøer i andre regioner og andre land, som også kan ha avgjørende kompetanse. Den sterke geografiske dimensjonen i nettverkene tyder på at mange bedrifter mangler nettverk som setter dem i stand til å samarbeide med universiteter utenfor regionen. Universitetene har ofte velutviklede nettverk med universiteter i andre regioner og kan hjelpe bedriftene til å finne aktuelle samarbeidspartnere også andre steder.

\section{Takksigelser}

Dette kapitlet bygger på forskning finansiert av EUs forsknings- og innovasjonsprogram Horisont 2020, kontraktnr. 722295. Det er en del av et Marie Skłodowska-Curie Actions Innovative Training Network om universitetenes rolle i innovasjon og regional utvikling (RUNIN), som koordineres av Universitetet i Stavanger.

\section{Referanser}

Abramovsky, L. \& Simpson, H. (2011). Geographic proximity and firm-university innovation linkages: Evidence from Great Britain. Journal of Economic Geography, 11, 949-977.

Audretsch, D. B. \& Feldman, M. P. (1996). R\&D spillovers and the geography of innovation and production. American Economic Review, 86(3), 630-640.

Audretsch, D. B., Lehmann, E. E. \& Warning, S. (2005). University spillovers and new firm location. Research Policy, 34, 1113-1122.

Breznitz, S. M. \& Feldman, M. P. (2012). The engaged university. Journal of Technology Transfer, 37(2), 139-157. 
Bruneel, J., D'Este, P. \& Salter, A. (2010). Investigating the factors that diminish the barriers to university-industry collaboration. Research Policy, 39(7), 858-868.

Clark, B. (1998). Creating entrepreneurial universities: Organizational pathways of transformation. Oxford: IAU Press.

D'Este, P. \& Patel, P. (2007). University-industry linkages in the UK: What are the factors underlying the variety of interactions with industry? Research Policy, 36(9), 1295-1313.

D’Este, P. \& Iammarino, S. (2010). The spatial profile of university-business research partnerships. Papers in Regional Science, 89, 335-350.

D’Este, P., Guy, F. \& Iammarino, S. (2013). Shaping the formation of universityindustry research collaborations: What type of proximity does really matter? Journal of Economic Geography, 13, 537-558.

Etzkowitz, H. \& Leydesdorff, L. (2000).The dynamics of innovation: From national systems and 'mode 2 ' to a triple helix of university-industry-government relations. Research Policy, 29(2), 109-123.

Fitjar, R. D. \& Rodríguez-Pose, A. (2013). Firm collaboration and modes of innovation in Norway. Research Policy, 42(1), 128-138.

Fitjar, R. D. \& Gjelsvik, M. (2018). Why do firms collaborate with local universities? Regional Studies, 52(11), 1525-1536.

Garcia, R., Araujo, V., Mascarini, S., Santos, E. G. \& Costa, A. (2015). Looking at both sides: How specific characteristics of academic research groups and firms affect the geographical distance of university-industry linkages. Regional Studies, Regional Science, 2, 518-534.

Gertler, M. S. 2003. Tacit knowledge and the economic geography of context, or the undefinable tacitness of being (there). Journal of Economic Geography, 3(1), 75-99.

Gjelsvik, M. \& Fitjar, R. D. (2016). University collaboration for sustainable competitive advantage: A resource-based perspective. I M. D. Parrilli, R. D. Fitjar \& A. Rodríguez-Pose (Red.), Innovation drivers and regional innovation strategies (s. 179-196). London: Routledge.

Göransson, B., Maharajh, R. \& Schmoch, U. 2009. New challenges for universities beyond education and research. Science and Public Policy, 36(2), 83-84.

Haus-Reve, S., Fitjar, R. D. \& Rodríguez-Pose, A. (2019). Does combining different types of collaboration always benefit firms? Collaboration, complementarity and product innovation in Norway. Research Policy, 48(6), 1476-1486.

Hewitt-Dundas, N., Gkypali, A. \& Roper, S. (2019). Does learning from prior collaboration help firms to overcome the 'two-worlds' paradox in universitybusiness collaboration. Research Policy, 48(5), 1310-1322.

Howells, J., Ramlogan, R. \& Cheng, S. L. (2012). Innovation and university collaboration: Paradox and complexity within the knowledge economy. Cambridge Journal of Economics, 36, 703-721. 
Jaffe, A. B. (1989). Real effects of academic research. American Economic Review, 79(5), 957-970.

Jongbloed, B., Enders, J. \& Salerno, C. 2008. Higher education and its communities: Interconnections, interdependencies and a research agenda. Higher Education, 56(3), 303-324.

Laursen, K., Reichstein, T. \& Salter, A. (2011). Exploring the effect of geographical proximity and university quality on university-industry collaboration in the United Kingdom. Regional Studies, 45, 507-523.

Mansfield, E. \& Lee, J. Y. 1996. The modern university: Contributor to industrial innovation and recipient of industrial R\&D support. Research Policy, 25, 1047-1058.

Perkmann, M. \& Walsh, K. (2007). University-industry relationships and open innovation: Towards a research agenda. International Journal of Management Reviews 9(4), 259-280.

Perkmann, M. et al. (2013). Academic engagement and commercialisation: A review of the literature on university-industry relations. Research Policy, 42(2), 423-442.

Pinheiro, R., Langa, P. V. \& Pausits, A. (2015). One and two equals three? The third mission of higher education institutions. European Journal of Higher Education, $5(3), 233-249$.

Statistisk sentralbyrå (2017). Nesten to tredjedeler av foretakene fornyer seg. Hentet fra https://www.ssb.no/teknologi-og-innovasjon/artikler-og-publikasjoner/ nesten-to-tredjedeler-av-foretakene-fornyer-seg

Storper, M. \& Venables, A. J. (2004). Buzz: Face-to-face contact and the urban economy. Journal of Economic Geography, 4(4), 351-370.

Stølen, S. \& Gornitzka, Å. (2017, 17. november). Tall som teller. Morgenbladet.

Vabø, A. \& Aamodt, P. O. (2005). Kvalitetsreformen og universitetene som masseutdanningsinstitusjon. NIFU STEP skriftserie 2/2005. Hentet fra http://hdl. handle.net/11250/280580

Woodward, D., Figueiredo, O. \& Guimarães, P. (2006). Beyond the Silicon Valley: University R\&D and high-technology location. Journal of Urban Economics, 6o, $15-32$.

Aall, C. (2018, 13. mai). Vi trenger ikke universiteter som kaller seg bærekraftige for omdømmets skyld. Forskning.no. 


\title{
En diskusjon om universitetets tredje rolle
}

\author{
James Karlsen
}

\section{Universitetet i Agder}

\begin{abstract}
In the last decades, the discourse about universities and their engagement with actors in their host regions has increased. Concepts such as the third mission and the entrepreneurial university aim to describe the engagement between the university and regional actors as a change in the role of the university. In theory, this is described as a transformation of the university. In practice, this is organised as an add-on of a range of different knowledge-transfer and market-oriented activities, which do not interfere with the core activities of teaching and research. These normative concepts have a significant influence on how universities are developing their regional engagement. In a case study from a university in Norway, University of Agder, the study shows a university that gradually is transforming from an ivory tower model towards more regional engagement. However, the transformation is taking time. At present, the university has a dual strategy for its regional engagement. One part is organised as an add-on activity, while the other is organised within the academic core of teaching. In the latter, students are co-creating knowledge together with regional actors. The study demonstrates that it is possible to organise regional engagement as co-creation of knowledge also within the academic core.
\end{abstract}

Keywords: university, regional engagement, the third mission, co-creation, mode 1, mode 2

\section{Innledning}

Interessen for universitetet som kunnskapsinstitusjon har økt sterkt blant politikkutformere de siste tiårene. I Norge har dette resultert $\mathrm{i}$ at 
flere tidligere høgskoler har blitt universitet, som Universitetet i Agder (UiA) i 2007 og Universitetet i Stavanger (UiS) i 2005. En fellesnevner for disse to institusjonene var at overgangen til universitet var et resultat av godt faglig arbeid og et langvarig samarbeid med politikere, næringsliv andre aktører i disse regionene. Denne interessen slutter imidlertid ikke ved oppnådd universitetsstatus, snarere tvert imot. Det stilles krav om økt regional engasjement fra de samme aktørene som bidro til universitetsstatusen (Karlsen, 2007). Den økte interessen for universitetet er ikke noe unikt for verken Agder eller Norge. Det er del av en generell trend. På den internasjonale arenaen er det spesielt OECD og EU som har identifisert universitetet som en sentral aktør for utvikling av innovasjon og økonomisk utvikling og har argumentert sterk for økt engasjement og samarbeid med næringslivet (OECD, 1999, 2007).

Som et resultat av den sterke interessen for universitetets rolle i kunnskapsøkonomien og kunnskapssamfunnet er det lansert flere begreper, som den tredje oppgaven (third mission), entreprenøruniversitetet (entrepreneurial university) og det engasjerte universitetet (the engaged university). Disse begrepene omhandler universitetets engasjement med sine omgivelser med formål om å bidra til enten innovasjon, økonomisk utvikling eller samfunnsutvikling i bred forstand. Det er imidlertid grunn til å ha et kritisk blikk på begrepene i diskursen. De ovennevnte begrepene drøfter for eksempel ikke konteksten som universitetet er en del av. Dermed baseres diskusjonen på en implisitt forutsetning om at alle kontekster er like, altså at alle regioner som universitetet er lokalisert $i$, er like. En annen implisitt forutsetning er at alle universiteter er like (homogene). Disse forutsetningene er selvsagt ikke holdbare i møtet med virkeligheten verken i Norge eller i andre kontekster. Både regioner og universiteter er forskjellige. Dette gjør at det ikke er så enkelt å sammenligne universiteter og regioner som en kan få inntrykk av.

I diskursen skilles det heller ikke alltid like klart mellom begrepenes meningsinnhold. Det er for eksempel høyst uklart hva som menes med engasjement (Krčmářová, 2012). Engasjement kan forstås som all 
aktivitet som et universitet har med eksterne aktører, eller som aktivitet med eksterne aktører i en region. Engasjement kan også presiseres ved bruk av begrepet universitetets tredje rolle. Den tredje rollen er et smalere og ved første øyekast mer presist begrep enn det generelle begrepet engasjement. Også dette begrepet er imidlertid komplekst, noe den kommende drøftingen vil vise. Formålet med denne drøftingen er for det første å sette søkelys på begrepet universitetets tredje rolle siden det er et mye brukt begrep i den internasjonale diskursen. Det er et begrep som har påvirket politikkutformere i mange land, og også påvirket strategier i enkelte universiteter. Det andre formålet med dette kapitlet er å se konkret hvordan strategier har endret seg over tid i et universitet, og analysere denne utviklingen. Det universitetet som er valgt som eksempel (case), er Universitetet i Agder. Dette universitetet er et av de nye universitetene i Norge, i motsetning til de "gamle» universitetene, som for eksempel Universitetet i Oslo. Det er også, som nevnt ovenfor, et universitet som ble etablert på grunn av nært samarbeid med regionale aktører i sin tid. Det kan derfor være interessant å se hvordan forholdet til regionen gjenspeiler seg i strategien til UiA.

\section{Universitetets rolle i forholdet til sine omgivelser}

Det finnes en rekke begreper som alle har som formål å belyse universitetets rolle i forholdet til sine omgivelser, enten omgivelsene er næringslivet, regionen eller samfunnet. Mangfoldet av begreper kan tolkes på flere måter. En tolkning er at diskursen er fragmentert fordi den mangler en enhetlig definisjon og forståelse av universitetets relasjon til omgivelsene. En annen tolkning er at nettopp mangfoldet av begreper viser at det er et interessant felt å studere, og at det er et forskningsfelt i utvikling. Det er den sistnevnte tolkningen som er min posisjon i dette kapitlet. Jeg har valgt å ta med begrepene som er mest relevante for formålet med dette kapitlet, se tabell 1. 


\begin{tabular}{|l|l|}
\hline Begrep & Kilde \\
\hline Third mission (Den tredje rollen) & $\begin{array}{l}\text { Molas-Gallart, Salter, Patel, Scott \& Duran (2002); } \\
\text { Molas-Gallart \& Castro-Martínez (2007) }\end{array}$ \\
\hline $\begin{array}{l}\text { The entrepreneurial university } \\
\text { (Entreprenøruniversitetet) }\end{array}$ & Etzkowitz (1983); Clark (1998); (Clark, 2004) \\
\hline $\begin{array}{l}\text { Regional innovation systems university model } \\
\text { (Universitetets rolle i det regionale } \\
\text { innovasjonssystemet) }\end{array}$ & Cooke (1992); Asheim, Smith \& Oughton (2011) \\
\hline $\begin{array}{l}\text { The engaged university } \\
\text { (Det engasjerte universitetet) }\end{array}$ & Boyer (1990); Uyarra (2010) \\
\hline $\begin{array}{l}\text { The civic university } \\
\text { (Det sivile universitetet) }\end{array}$ & Goddard, Hazelkorn, Kempton \& Vallance (2016) \\
\hline
\end{tabular}

Tabell 1. Begreper som omhandler relasjonen mellom universitetet og omgivelsene.

\section{Den tredje rollen}

Begrepet den tredje rollen, eller den tredje oppgaven, er som nevnt et mye brukt begrep i den internasjonale diskursen. Begrepet tredje viser at universitetet også har to andre roller, nemlig forskning og undervisning. Disse to rollene er også kjent som universitetets kjerneoppgaver. Begrepet den tredje rollen er et resultat av erkjennelsen av forskningens betydning for innovasjon i næringslivet og økonomisk utvikling i samfunnet. For at kunnskapen skal komme ut i samfunnet, må det derfor etableres en kontakt mellom forskning og samfunnet. En av de mer brukte definisjonene av dette begrepet er lansert av Molas-Gallart et al. (2002) i forbindelse med en rapport til en gruppe av eliteuniversiteter i Storbritannia. Et av formålene med rapporten var å etablere en akseptert definisjon med tilhørende indikatorer for presist å kunne måle omfanget av den tredje rollen og for å kunne sammenligne universiteter. Den tredje rollen ble definert slik:

all activities concerned with the generation, use, application and exploitation of knowledge and other university capabilities outside academic environments. (Molas-Gallart \& Castro-Martínez, 2007, s. 321)

Selv om begrepet er mye brukt i diskursen om universitetets engasjement med sine omgivelser, er det ennå ikke etablert en felles standard mellom universiteter i ulike land for presist å kunne si noe om omfanget av den 
tredje rollen (Molas-Gallart \& Castro-Martínez, 2007). Hvor stor den tredje rollen er i ulike universiteter, er med andre ord vanskelig å si noe sikkert om. Hva som legges i begrepet, og hvordan det måles, varierer fra land til land (Trippl, Sinozic \& Smith, 2015).

Begrepet den tredje rollen kan gi inntrykk av at denne rollen er like viktig som forskning og undervisning. I Norge er det gjennom strategiplaner en tendens til å likestille den tredje rollen med forskning og undervisning (Gulbrandsen \& Nerdrum, 2009). Det er viktig for universiteter å vise at de har en strategi for forholdet til sine omgivelser (Lawton-Smith \& Waters, 2015). Imidlertid er den tredje rollen lite kjent blant akademisk ansatte på universitetene i Storbritannia (Watson, Hall \& Tazzyman, 2016, s. 160). Selv om den politiske retorikken i Storbritannia har fokusert på den økonomiske betydningen av universitetet, så er praksis nyansert når det gjelder arbeidsdelingen mellom universitetene når det gjelder kommersialisering av forskning og regionalt engasjement (Trippl et al., 2015).

\section{En nyansering av den tredje rollen}

Trippl et al. (2015) differensierer mellom en smal og en bred versjon av den tredje rollen. Den smale rollen knytter de til begrepene entreprenøruniversitetet (Clark, 1998; Etzkowitz, 1983) og til universitetets rolle i den regionale innovasjonssystem (RIS)-modellen. Felles for disse to begrepene er deres fokus på økonomi og teknologi (Trippl et al., 2015). Mye av litteraturen om universitetets entreprenøraktiviteter har hatt en slagside mot harde aktiviteter, slik som spin-off, patentering og lisensiering, og mindre mot såkalte myke initiativer og deres potensial for økonomisk utvikling (Lucas, Cooper, Ward \& Cave, 2009). Dette har ført til en forståelse av at entreprenøraktiviteter er lik kommersialisering av forskning (Philpott, Dooley, O’Reily \& Lupton, 2011). Dette er en svakhet som RIS-modellen ikke har. Den inkluderer også myke initiativ som samarbeid, nettverksaktiviteter og læring mellom aktørene i forsknings- og utviklingssystemet (universitet og forskningsinstitusjoner) og aktørene i produksjonssystemet (bedriftene) (Trippl et al., 2015). Ut fra denne drøftingen kan den smale tredjerollen deles inn i en hard og en myk rolle. Den 
harde rollen er knyttet til aktiviteter som leder til kommersialisering av teknologi og spin-off fra universitetet, mens den myke rollen er knyttet til utvikling av kunnskap og ferdigheter i det regionale innovasjonssystemet med formål å forbedre innovasjonsevnen hos aktørene i systemet og forbedre selve systemet.

RIS-modellen setter søkelys på at universitetet er lokalisert i et sted og en region, mens de andre modellene implisitt forutsetter at alle regioner er like, som tidligere nevnt. De andre modellene forutsetter med andre ord at den regionale dimensjonen ikke spiller noen rolle. Det er selvsagt ikke riktig. Ved å bringe inn den regionale dimensjonen blir diskusjonen om universitetet nyansert på flere måter. Universitetet er lokalisert til et sted og i en region, og bare ved å være lokalisert i en region har universitetet effekter på sine omgivelser, se for eksempel kapitlet til Arbo i denne boka. Det kan kalles den passive effekten av å ha en institusjon som et universitet lokalisert i en region (Karlsen, 2007). Når det gjelder universitetets rolle, er det imidlertid ikke denne en vanligvis snakker om, men om den aktive, engasjerte rollen der kunnskap anvendes med formål om innovasjon, økonomisk utvikling og regional utvikling.

Den brede, regionale rollen omfatter universitetets relasjoner og aktiviteter med øvrige sektorer av samfunnet som ikke omfattes av den snevre tilnærmingen, som kultur og sosiale forhold i det sivile samfunn. Kategoriseringen hos Trippl et al. (2015) innbefatter begreper som Mode 2 universitetet (Nowotny, Scott \& Gibbons, 2001) og det engasjerte universitetet (Boyer, 1990; Uyarra, 2010). Videre kan også The Civic University av Goddard et al. (2016) regnes inn i denne kategorien.

Goddard et al. (2016) har kritisert den smale rollen fordi den kan forstås som om den primært er en rolle for å sikre ekstern finansiering til universitetet, altså en tredje inntektskilde (third stream). I denne rollen opptrer universitetet som en akademisk kapitalist, noe som blant annet kan gå utover den frie og uavhengige kunnskapsproduksjonsrollen og det å levere kritikk av samfunnsutvikling og rådende oppfatninger i samfunnet (Slaughter \& Rhoades, 2004). Konsekvensen av denne prioriteringen er at aktiviteter som ikke bringer inn midler til universitetet, nedprioriteres og skyves ut i periferien av hva universitetet bør engasjere seg i. 
Begrepet den brede regionale rollen tar høyde for at universitetet også bør engasjere seg i andre utfordringer i en region, som miljø og sosiale og kulturelle utfordringer, selv om disse ikke nødvendigvis finansieres av eksterne aktører (Goddard et al., 2016).

De brede universitetsmodellene til Boyer (1990) og Goddard et al. (2016) kan kritiseres for at de mangler empirisk belegg. De er teoretiske konstruksjoner som ikke er testet tilstrekkelig ut i praksis. Modellene har også begrepsmessige svakheter. De klargjør for eksempel ikke hvordan universitetet kan integrere og koordinere de tre rollene på en effektiv måte (Trippl et al., 2015). Felles for både den smale og den brede tredje rollen er at i mange land, som i Norge, er det nasjonale rammebetingelser og virkemidler som gir de sterkeste føringene for universitetet. De regionale føringene i form av økonomiske virkemidler er langt svakere enn de nasjonale virkemidlene, selv om retorikken fra regionale aktører om regionalt engasjement overfor universitetet kan være sterk.

\section{En ytterligere presisering: Samarbeid eller samskaping}

Tabell 2 illustrerer tre forskjellige relasjoner mellom universitetet og regionen og tre forskjellige måter å skape kunnskap på. De tre måtene er Mode o (Regeer \& Bunders, 2009), Mode 1 og Mode 2 (Gibbons et al., 1994). I Mode o er regionen og universitetet adskilt fra hverandre. Universitetet har en autonom rolle, og den monodisiplinære kunnskapen dominerer. I denne rollen forsker universitetet $p a ̊$ regionen. I Mode 1 er relasjonen mellom universitetet og regionen preget av samarbeid. Vitenskapelig kunnskap brukes til å løse samfunnsmessige utfordringer og sikre økonomisk vekst, og både mono-, multi-, og disiplinær kunnskap anvendes. I Mode 1 tas det for gitt at kunnskap skapt i universitetet enkelt kan overføres til regionen og anvendes der. I denne rollen er universitetet et instrument for regionen når det gjelder å løse samfunnsmessige utfordringer. Karakteristisk for denne er at universitetet forsker for regionen. Denne formen for regionalt engasjement er basert på ideen om at kunnskap enkelt kan overføres fra universitetet til næringslivet eller til offentlig sektor. 
I Mode 2 er samskaping den dominerende metoden når ulik type kunnskap, inkludert erfaringsbasert kunnskap, bringes sammen for å løse felles utfordringer. I denne rollen forsker universitetet med regionen. Det er verdt å merke seg at i Mode 1 er det samarbeid som betones i relasjonen mellom universitetet og regionen, mens det i Mode 2 er samskaping. Dette er et begrep som ytterligere bidrar til å nyansere begrepet den tredje rollen. Samskaping kan forstås på forskjellige måter og har fellestrekk med begrepet samarbeid. I Bokmålsordboka (2018b) defineres samskaping som det at flere skaper noe sammen, mens samarbeid defineres som det å arbeide i fellesskap (Bokmålsordboka, 2018a). Selv om begrepene er nærliggende, er de forskjellige. Å arbeide i fellesskap er ikke det samme som i fellesskap å skape noe sammen.

På engelsk er samskaping co-creation:

a way of working together where people from different backgrounds are invited to jointly produce a product or service that will benefit them all. (Macmillan Dictionary, 2018)

Tabell 2. Tre former for vitenskapelig kunnskapsutvikling.

\begin{tabular}{|c|c|c|c|}
\hline & $\begin{array}{l}\text { Relasjonen mellom universitetet } \\
\text { og regionen }\end{array}$ & $\begin{array}{l}\text { Kunnskapens rolle i regional } \\
\text { utvikling }\end{array}$ & Type kunnskap \\
\hline Mode 0 & $\begin{array}{l}\text { Separat } \\
\text { Universitetet og regionen er } \\
\text { adskilt fra hverandre. }\end{array}$ & $\begin{array}{l}\text { Autonom } \\
\text { Mer vitenskapelig kunnskap } \\
\text { leder til fremskritt. }\end{array}$ & Monodisiplinær \\
\hline Mode 1 & $\begin{array}{l}\text { Samarbeid } \\
\text { Samarbeid mellom universitetet } \\
\text { og regionen, men basert på } \\
\text { ideen om lineær overføring av } \\
\text { kunnskap der kunnskapen først } \\
\text { skapes i universitetet for deretter } \\
\text { å overføres til regionen }\end{array}$ & $\begin{array}{l}\text { Instrumentell } \\
\text { Utvikling av politikk relevant } \\
\text { kunnskap fører til løsning av } \\
\text { samfunnsmessige utfordringer } \\
\text { og stimulerer til økonomisk } \\
\text { utvikling }\end{array}$ & $\begin{array}{l}\text { Mono, multi- og } \\
\text { interdisiplinær } \\
\text { kunnskap }\end{array}$ \\
\hline Mode 2 & $\begin{array}{l}\text { Samskaping } \\
\text { Regionen og universitetet jobber } \\
\text { aktivt med å finne måter å } \\
\text { strukturere og lede komplekse } \\
\text { endringsprosesser i samfunnet }\end{array}$ & $\begin{array}{l}\text { Transdisiplinært } \\
\text { Vitenskapelig kunnskap } \\
\text { (mono-, multi- og } \\
\text { interdisiplinær) er en del av } \\
\text { samskapingsprosessen, OG } \\
\text { denne prosessen er en del av } \\
\text { kunnskapsutviklingen innenfor } \\
\text { vitenskapen }\end{array}$ & $\begin{array}{l}\text { Mono-, } \\
\text { multi- og } \\
\text { interdisiplinær } \\
\text { kunnskap og } \\
\text { erfaringsbasert } \\
\text { kunnskap }\end{array}$ \\
\hline
\end{tabular}

Modifisert etter Regeer og Bunders (2009, s. 12). 
Denne definisjonen viser for det første at samskaping er en måte eller en metode å jobbe sammen på. For det andre viser den at de som jobber sammen, er forskjellige, som forskjeller i formell kunnskap, det vil si forskjellig utdanning. Det kan også være ulik type erfaringsbasert kunnskap. Definisjonen viser for det tredje at det som skapes, skal være til fordel for alle. Et siste poeng er at det skal være et produkt eller en tjeneste som skapes sammen. Dette siste er en snever forståelse av samskaping, altså samskaping som en prosess for å skape kommersielle produkter og tjenester. Samskaping som metode kan jo også brukes til å skape noe sammen som ikke nødvendigvis har en forretningsmessig nytte, men som kan ha nytte for samfunnet på lang sikt.

\section{Den tredje rollen i en regional kontekst}

Med utgangspunkt i den foregående drøftingen kan den regionale rollen forstås på flere måter. I tabell 3 er dette illustrert. I den første dimensjonen i tabellen er den tredje rollen forstått som en smal eller bred regional rolle. Den andre dimensjonen gjelder samarbeid versus samskaping. Dette gir fire typologier. De to første typologiene er basert på ideen om at kunnskap enkelt kan overføres fra universitetet til næringslivet (den første formen) eller til aktører som ikke er i produksjonssystemet, det vil si offentlig sektor eller det sivile samfunnet i regionen (den andre typologien). I den første typologien kan for eksempel den lineære innovasjonsmodellen (Jensen, Johnson, Lorenz \& Lundvall, 2007) plasseres der det er fokus på teknologi, økonomi og innovasjon. Den kan også forstås som en bred regional rolle som fokuserer på mer enn økonomi og innovasjon, det vil si på områder som kultur og levekår. Kunnskap skapes både i den smale og den brede regionale rollen. De to siste typologiene er basert på samskaping og kontekstualisering av kunnskap mellom aktører i universitetet og aktører i regionen. I den tredje formen er det samskaping av kunnskap med aktører i næringslivet, og den fjerde formen berører samskaping med aktører utenfor produksjonssystemet. Begge de siste typologiene omhandler komplekse utfordringer der det ikke er et klart svar på hvordan de kan løses. Løsningen må derfor samskapes mellom aktørene. Denne typologien vil bli brukt videre i analysen av casen, som presenteres i neste avsnitt. 
Kort oppsummert og presisert: Det er ikke universitetets engasjement gjennom alle tre rollene som er fokus i denne drøftingen, men universitetets forskningsmessige kunnskap anvendt i en regional kontekst. Denne presiseringen av den tredje oppgaven i en regional kontekst er videre nyansert til fire typologier. For det første om engasjementet er smalt eller bredt, og for det andre om kunnskapsprosessen i hovedsak er basert på samarbeid eller samskaping. Denne presiseringen gjør at kanskje den mest sentrale rollen for universitetet, nemlig utdanning, ikke er gjenstand for analyse i dette kapitlet. Utdanning av sykepleiere, lærere, ingeniører og økonomer er en svært viktig del av universitetets samfunnsoppdrag. Dette er en type engasjement som strekker seg langt tilbake i tid. Både sykepleier- og lærerutdanningene er avhengig av et godt samarbeid med regionale institusjoner som sykehus og skoler for at studentene skal få relevant praksis og prøvd ut sine kunnskaper før de slippes endelig ut på arbeidsmarkedet. Også ingeniørutdanningene kommer etter med ingeniørpraksis, likeledes utplassering av økonomer i næringslivet og offentlig sektor. Heller ikke er forskning, som ikke er relevant i en regional kontekst, gjort til gjenstand for analyse.

\begin{tabular}{|l|l|l|}
\hline $\begin{array}{l}\text { Engasjement } \\
\text { Kunnskapsprosesser } \\
\text { i hovedsak preget av }\end{array}$ & Smal & Bred \\
\hline Samarbeid & $\begin{array}{l}\text { I: Samarbeid om en overføring } \\
\text { av kunnskap fra universitetet til } \\
\text { næringslivet eller offentlig sektor }\end{array}$ & $\begin{array}{l}\text { II: Samarbeid om overføring av } \\
\text { kunnskap til sivile samfunn i } \\
\text { regionen }\end{array}$ \\
\hline Samskaping & $\begin{array}{l}\text { III: Samskaping av kunnskap } \\
\text { med aktører i næringslivet } \\
\text { eller offentlig sektor for å løse } \\
\text { komplekse utfordringer }\end{array}$ & $\begin{array}{l}\text { IV: Samskaping av kunnskap } \\
\text { med aktører i regionen for å løse } \\
\text { komplekse regionale utfordringer }\end{array}$ \\
\hline
\end{tabular}

Tabell 3. Fire typer av den tredje rollen i en regional kontekst.

\section{Introduksjon til casen}

\section{Om Universitetet i Agder}

Universitetet i Ager representerer et av de nye universitetene i Norge, som ble heiet frem av regionale aktører. Siden Universitetet i Agder ble akkreditert som universitetet i 2007, har det kommet flere nye universiteter i 
Norge, som Universitet nord (2016) Universitetet i Sørøst-Norge (2016) og OsloMet - storbyuniversitetet (2018). Dette har bidratt til at den regionale dimensjonen og regionalt engasjement er blitt viktig i flere regioner i de senere årene.

Historien om Universitetet i Agder kan føres tilbake til 1828, ved etableringen av Kristiansand Museum og etableringen av lærerutdanningen gjennom Holt Seminar i 1839 (Breen \& Jahr, 2017). Per 2019 er det ca. 1300 ansatte og ca. 13 ooo studenter fordelt på campusene i Kristiansand og Grimstad. Det gis tilbud innenfor 15 ph.d.-spesialiseringer, 33 masterprogrammer og 44 bachelorprogrammer, samt en rekke etter- og videreutdanningskurs. UiA har valgt rektor som også leder universitetsstyret, som består av representanter fra ansatte, studenter og eksterne medlemmer som oppnevnes av Kunnskapsdepartementet. Universitetsdirektøren er den øverste administrative lederen med ansvar for å iverksette vedtak fattet av universitetsstyret.

I Agderregionen, som utgjøres av Aust-Agder og Vest-Agder fylke, bor det i 2019 vel 305 ooo innbyggere, som er 5,8\% av Norges befolkning. I Kristiansand bor det vel 92 ooo og i Grimstad vel 23 ooo innbyggere, det vil si at over en tredel av befolkningen i Agder bor i disse to kommunene.

\section{Metode}

Casestudie som metode (Yin, 2013) er valgt fordi det i dette tilfellet er vanskelig å avgrense den tredje rollen regionalt på en entydig måte. Det gjelder ikke bare det kontekstuelle skillet, det vil si skillet mellom det som studeres og konteksten (Yin, 2013), men også fordi den regionale rollen må ses i en tidsdimensjon. Metodisk gir dette en utfordring når det gjelder validitet og reliabilitet. Jeg har valgt å løse dette ved å presentere sekundær data i form av formelle skriftlige kilder, som strategiplaner. Ulempen er at en ikke får dokumentert de uformelle prosessene som ligger til grunn for disse kildene, og heller ikke hvordan strategiplanene er implementert. Heller ikke får en fram data om faktiske samarbeids- og samskapingsrelasjoner mellom ansatte ved UiA og regionen. De nyere data fra $2017 \mathrm{og}$ 2018 er basert på intervjuer, observasjon og aktiv deltakelse som metode i noen av de prosessene som har vært initiert i regi av UiA når det det 
gjelder implementering av et strategiområde i den siste strategiplanen for perioden 2016-2020. Denne blandede metodiske strategien har bidratt til å strukturere presentasjon og drøftingen av casen. I første del av casen er fokuset på strategidokumenter fra 1995 til 2016 og det som skrives om forholdet til Agder som region. I andre del av casen er fokuset på hvordan et strategiområde om den regionale rollen er implementert i perioden 2017-2019. I beskrivelsen er det lagt vekt på å vise endring ved bruk av overskrifter som knytter an til typologien som er utviklet i tabell 3 . I beskrivelsen er det fokus på det regionale i de nevnte dokumentene. Det må understrekes at disse dokumentene tar opp en rekke temaer som ikke er nevnt i beskrivelsen, som internasjonalisering, forsknings- og undervisningskvalitet og organisasjonen og organisasjonskulturen. Heller ikke berøres utdanning, jamfør diskusjonen i forrige avsnitt.

\section{Utvikling av regionalt engasjement ved UiA}

\section{Fra en autonom til en lineær forståelse av universitetets rolle i regionen}

I Strategiplanen Mot år 2000 - Strategisk plan for Høgskolen i Agder, er ikke forholdet til Agder som region drøftet i særlig grad. Et av hovedmålene i planen er å formidle ny kunnskap til regionen (Høgskolen i Agder, 1994). Det understrekes i planen at Høgskolen i Agder er en viktig ressurs for regionen. Videre står det i planen:

Kombinasjonen av lokalt forankret og internasjonalt anerkjent forskning er et annet viktig kjennetegn. Høgskolen kan bidra til utviklingen regionalt gjennom å hente problemstillinger og empiriske data fra landsdelen. (Høgskolen i Agder, 1994, s. 7)

I denne planen ses regionen på som en kilde til problemstillinger og data som forskerne kan bruke, altså å forske på regionen. Universitetets rolle er å formidle ny kunnskap til regionen. Dette viser at det er både den autonome og den lineære forståelsen av universitetets rolle som dominerer i dette dokumentet, ref. tabell 2. I visjonen i denne planen tilkjennegis en ambisjonen om å utvikle Høgskolen i Agder til et universitet som 
kombinerer tradisjonelle universitetsfag og ulike profesjonsutdanninger (Høgskolen i Agder, 1994, s. 6). Som nevnt i innledningen ble overgangen til universitet støttet sterkt av regionale aktører. I forbindelse med denne overgangen var det rundt 2005 en rekke artikler i regionavisen Fædrelandsvennen om det kommende universitetets regionale engasjementet. Daværende redaktør av Fædrelandsvennen, daværende NHO-direktør og styreformannen for Sørlandets Kompetansefond argumenterte for at det nye universitetet måtte ta en aktiv regional rolle for å bidra til å forbedre konkurransevilkårene og være et nyttig universitet for industrien (Karlsen, 2007). Diskusjonen den gangen gikk langt i å spesifisere hvilken type industri UiA burde engasjere seg med, som prosessindustrien, energisektoren, den maritime industrien, IKT og leverandører til oljeindustrien (Karlsen, 2007). Denne diskusjonen fulgte i stor grad i sporene til det som tidligere har blitt kalt den smale regionale rollen. Diskusjonen er imidlertid lite nyansert når det gjelder både resultater av engasjementet og organisering. Implisitt i argumentene fra aktørene i næringslivet er den en forståelse av at kunnskap skapes i Mode 1 og så overføres til industrien, som så kan ta den i bruk. Det er altså den lineære forståelsen av kunnskap som dominerer, selv om dette begrepet ikke brukes i avisdiskursen.

\section{Fra en smal lineær forståelse av universitetets regionale rolle til en bredere forståelse}

Kimen til en bredere forståelse av universitetets regionale engasjement er imidlertid allerede uttrykt i et notat fra 2004 der ulike universitetsmodeller og begreper drøftes. I notatet står det følgende:

Det hevdes altså at det er et trekk ved vår tid at vitenskapen og kanskje sarlig de nyere universitetene utvikler seg stadig normere samfunnet omkring... Dermed kommer universitetet ned fra sitt elfenbenstårn, samfunnet trekker inn i universitetet og universitetet trekker inn i samfunnet. Universitetet blir en samspiller med sin region, men mer enn det, også en integrert del av sin region. (Høgskolen i Agder, 2004, s. 23)

I strategiplanen Mot 2010 følges dette opp med å understreke at UiA ønsker å bli et forbilde for hvordan en utdannings-og forskningsinstitusjon 
kan bli en aktiv medspiller i egen region (Universitetet i Agder, 2005, s. 2). Begreper fra innovasjonslitteraturen, som innovasjon og entreprenørskap, har fått innpass i denne planen på overskriftsnivå. Disse begrepene koples både til utdanning og forskning, og det slås fast at i forpliktende samarbeid med regionen skal det videreutvikles næringsrelevante satsningsfelt (Universitetet i Agder, 2005, s. 6), men planen sier ikke noe om hvilke næringsfelt. Planen favner imidlertid bredere enn næringsperspektivet. Også velferd, demokrati, samfunn, kunst og kulturelle ytringer nevnes i en regional kontekst. Kunst og kulturelle ytringer koples både til næringsutvikling og til en bredere og dypere forståelse av kunst og kulturens plass i samfunnet.

I denne planen brukes begrepet medskapende. Det skrives at UiA må ha en aktiv holdning og innta en medskapende rolle i utviklingen av Agder både gjennom deltakelse i fora og møteplasser der nærings- og samfunnsliv i regionen møtes, og i etablering av nye møteplasser (Universitetet i Agder, 2005, s. 7-8). Signalet fra planen er at tiden som passiv observatør til den regionale utviklingen er over. Det aktive regionale engasjementet tydeliggjøres. Strategien for UiA som en aktiv samfunnsaktør i samarbeid med samfunn og arbeidsliv følges også opp i den påfølgende strategiplanen (Universitetet i Agder, 2012). Innovasjonsaspektet brukes ikke lenger bare på overskriftsnivå, men diskuteres og knyttes til kommersialisering:

UiA skal bidra til innovasjon i privat og offentlig sektor, og kunnskap fra forskningsog utviklingsarbeid ved universitetet skal komme til anvendelse for samfunnet ved kommersialisering og annen måte. UiA skal bidra aktivt til nettverk og innovasjonssystemer som er relevante for arbeidslivet i offentlig og privat virksomhet. UiA skal bidra til utvikling av gode samarbeidsmodeller med organisasjoner og arbeidsliv. UiA skal vore en samarbeidspartner i realiseringen av Regionplan Agder 2020. (Universitetet i Agder, 2012, s. 5)

Selv om notatet problematiserer at universitetet er en del av Agderregionen, tas det ikke stilling til i dette dokumentet hvordan dette samspillet skal organiseres, og med hvilke ressurser. Det er fremdeles den lineære forståelsen som gjennomsyrer planen, så selv om begrepet medskapende er introdusert, er ikke begrepet problematisert. Kimen til 
samskapingsbegrepet, som blir introdusert i neste strategiplan, bygger på dette begrepet

\section{Samskaping av kunnskap}

I strategiplanen 2016-2020 er visjonen Samskaping av kunnskap (Universitetet i Agder, 2016). I denne planen er Samfunnsengasjement og nyskaping ett av tre hovedområder. Om dette hovedområdet står det at:

UiA vil øke sitt engasjement for utviklingen av det regionale kultur-og noringsliv, offentlig virksomhet og samfunnslivet for øvrig. Ansatte og studenter vil vore aktive i ulike fora for å sikre at universitetet er tett på de store samfunnsutfordringene, som borekraft, økonomisk utvikling, mangfold, likestilling, migrasjon og sosial rettferdighet. (Universitetet i Agder, 2016, s. 6)

Det regionale engasjementet er viet plass i planen. Både den smale og den brede regionale rollen er tydelig å spore i strategien, selv om disse begrepene ikke brukes i dokumentet. Temaer som bærekraft, likestilling, mangfold, migrasjon og sosial rettferdighet hører til den brede rollen. Ambisjonene ligger opp til begrepet The civic university hos Goddard et al. (2016, s. 5), et begrep som vektlegger universitetet som en organisasjon som ikke bare responderer med høyere utdanning, men også engasjerer seg overfor en rekke grupper og organisasjoner på ulike geografiske nivåer. Strategien gir bud om et ansvarlig universitetet, som gjerne vil engasjere seg i komplekse samfunnsutfordringer, uavhengig av nivå. Det er også interessant at det brukes begrepet ansatte, ikke begrepet akademisk eller vitenskapelig ansatte, som ofte brukes i den akademiske litteraturen for å skille mellom de rollene som ansatte kan ha i universitetet. Også det ikke-vitenskapelige personalet, som den administrative ledelsen, kan selvsagt engasjere seg i regionale problemstillinger på vegne av organisasjonen. Utfordringen blir da hvordan regionale aktørers behov for akademisk kunnskap koples internt i universitetet. I den videre drøftingen vil jeg fokusere på strategiområdet Samfunnsengasjement og nyskaping fordi dette området tar opp det regionale engasjementet mellom UiA og regionen. Som en av de intervjuede skrev i en e-post til meg om UiAs forhold til regionen: 
UiA har, som vi snakket om (og som du selvsagt vet, du har jo vert opptatt av dette selv minst like lenge) vort opptatt av den noere samhandlingen med regionen lenge, men det er kanskje først med samskapingsverkstedet og det nye studieemnet ${ }^{1}$ at dette «materialiserer» seg.

\section{Samskapingsverkstedet - Samskaping av kunnskap i en bred regional kontekst}

I forbindelse med oppfølging av strategiplanen for 2016-2020 ble det utpekt tre områder. Ett av disse områdene omhandlet samfunnsengasjement og nyskaping, det vil si forholdet til regionen (Universitetet i Agder, 2018b). Samskapingsverkstedet var et prosjekt med en visjon om å etablere en kreativ sosial arena der studenter, lærere, forskere og eksterne partnere møtes på tvers av fag, institutter og fakulteter, for å samarbeide om utfordringer i samfunnet. Fokus for samskapingsverkstedet var altså samskaping og interdisiplinær kunnskap. Et resultat fra dette prosjektet er det interdisiplinære emnet SV 420 UiA Samskaping OpenLab, og det andre er UiA CoLab ${ }^{2}$. Det første tiltaket er beskrevet slik i emnebeskrivelsen:

Formålet med emnet er å introdusere studentene til nyskapning og samskaping på tvers av fagfelt, sektorer og organisatoriske grenser i en regional kontekst. Gjennom samarbeid og dialog skal det jobbes med å løse komplekse regionale utfordringer. I dette emnet skal studentene vere i sentrum for en samarbeidsbasert loreprosess der aksjonsforskning, problembasert loering (PBL) og design thinking er rammene for emnet. (Universitetet i Agder, 2019a)

UiA CoLab er beskrevet som en

strategisk satsning ved Universitetet i Agder (UiA) og skal bli en arena for samskaping av kunnskap og sosial innovasjon for Agder. Laben ... har som mål å voere en kreativ, sosial arena, der eksterne partnere, studenter og ansatte møtes på tvers av fag, fakulteter og institusjoner for å samarbeide om utfordringer $i$ samfunnet. UiA CoLAB ønsker å fasilitere nyskapende aktiviteter basert på designdrevet metode

Det nye studieemnet er SV 420, som blir presentert i neste avsnitt.

2 Co står for colaborare, som er det latinske ordet for å arbeide i fellesskap mot et felles mål. Lab er en forkortelse for laboratorium. 
for endring og løsning av komplekse samfunnsmessige problemer. (Universitetet $i$ Agder, 2019b) ${ }^{3}$

Begge disse to tiltakene legger vekt på det regionale engasjementet gjennom samskaping av kunnskap. De har en bred tilnærming, det vil si det som tidligere er benevnt for den brede regionale rollen. Tilknytningen til UiAs visjon tilkjennegis tydelig. Det er imidlertid også forskjeller mellom disse to tiltakene. SV 420 er integrert i den akademiske kjernen, altså etter Goddard et al. (2016) Civic University modell. CoLab derimot er organisert som en egen enhet med ansatte som skal jobbe med aktiviteter i regi av senteret, det vil si som en klassisk tredje-rolle-organisering utenfor den akademiske kjernen. ${ }^{4}$ Det regionale engasjementet har med andre ord fått to organisatoriske løsninger ved UiA.

Det regionale engasjementet ved UiA slutter ikke ved disse tiltakene. I tillegg til disse prosjektene ble også emnet ORG 503 - Innovasjon i offentlig sektor knyttet til Samskapingsverkstedet. Dette er et emne som gis ved Institutt for arbeidsliv og innovasjon ved Handelshøyskolen ved UiA. Instituttet er lokalisert til Campus Grimstad, og har som flere andre institutter ved denne campusen en lang tradisjon for samarbeid med regionale aktører. Emnet ble koplet til Samskapingsverkstedet som et resultat av et nedenfra og opp-tiltak fra to professorer fra det nevnte instituttet. Innholdet i faget er utviklet av fagansvarlige ved dette instituttet, og det regionale engasjementet er et resultat av en samskapingsprosess mellom de fagansvarlige, næringssjefen i Grimstad og Grimstad næringsforening. Dette viser at regionalt engasjement også kan utvikles gjennom samskaping mellom fagpersoner i den akademiske kjerne og regionale aktører.

\section{Etablering av sentre for innovasjon}

Selv om fokus i dette kapitlet har vært på strategiplaner, så må det likevel nevnes to viktige tiltak som er etablert de siste årene ved UiA. Begge

3 Beskrivelsen av CoLab er fra stillingsannonsen som utløp 1.2.2019, der to stillinger ble annonsert ledig.

4 Formelt er det Samfunnsvitenskapelig fakultet som er ansvarlig for både CoLab og for SV 420. Senter for Entreprenørskap ved Handelshøyskolen ved UiA har imidlertid fått i oppgave å planlegge, iverksette og drifte CoLab. 
tiltakene er etablert som egne organisatoriske enheter. Det ene er Mechatronics Innovation Lab, og det andre er i4Helse. Begge disse tiltakene kan klassifiseres innenfor den smale, regionale rollen. Det første tiltaket har fokus på innovasjon rettet mot næringslivet, og det andre på innovasjon innenfor helse- og omsorgstjenester. Felles for tiltakene er fokus på teknologi, det vil si det som i drøftingen ble benevnt som den smale, harde tredje rollen.

\section{Konklusjon}

Formålet med dette kapitlet har vært å drøfte begrepet universitetets tredje rolle og å etablere et analytisk rammeverk for å kunne analysere den tredje rollen. Den teoretiske drøftingen viser at den tredje rollen er et komplekst begrep som omhandler konstruksjon av kunnskap med aktører utenfor universitetet, der formålet er anvendelse av vitenskapelig kunnskap for innovasjon og økonomisk utvikling. Den tredje rollen kan deles inn i en smal og en bred rolle, og det kan videre skilles mellom samarbeid og samskaping. I tabell 3 er det analytiske rammeverket vist. Dette rammeverket er testet på UiA ved å gå gjennom strategiplaner.

Studien viser at UiA som institusjon langsomt har endret sin forståelse av relasjonen til Agderregionen. Denne forståelsen reflekterer diskursen om universitetets rolle i samfunnet og i en regional kontekst. I begynnelsen av perioden (1995) ble regionen sett på som en kilde til data for forskning og som en arena for kunnskapsformidling. Skillet mellom daværende Høgskolen i Agder og regionen var tydelig. Den gang så høgskolen seg adskilt fra regionen, selv om institusjonen var lokalisert i den. I løpet av perioden fram til siste strategiplan har det regionale engasjementet langsomt blitt tydeligere. Selv om det er blitt tydeligere, er innholdet i planene fremdeles relativt abstrakt og med få referanser til regionen, med unntak av navnet «Agder», som viser til den regionale lokaliseringen. Ser en bort fra navnet, er strategiplanen relativt universell og kunne passet for flere universiteter. UiA har med andre ord noe å gå på når det gjelder kontekstualisering og tydeliggjøring av sitt regionale engasjement, både når det gjelder samarbeid og samskaping med næringslivet, offentlig sektor og det sivile samfunn. Dette kan for eksempel skyldes implisitte 
spenninger, som en ikke vil gjøre eksplisitt, for å unngå konflikt. Eksempler på spenninger kan være mellom det regionale og det internasjonale, mellom regionalt engasjement og forskning og mellom regionalt engasjement og relevant undervisning. I komplekse organisasjoner, som universitetet, er det ikke uvanlig med denne typen spenninger (Pinheiro, Benneworth \& Jones, 2012).

Det regionale engasjementet ble i siste strategiplan konkretisert gjennom Samskapingsverkstedet, som initierte flere prosjekter knyttet til undervisning mellom UiA og aktører i regionen. UiA har valgt en todelt modell når det gjelder regional samskaping ved å videreføre prosjektet (SV 420) og etablere en ny samskapingsenhet (CoLab) som en tredje rolle ved Campus Kristiansand. Dette kan ses på som et forsøk på å institusjonalisere regionalt engasjement både i den akademiske kjernen og som et tillegg til eksisterende virksomhet. Spørsmålet er om dette kan skape spenning mellom undervisningsdelen og den eksternt organiserte virksomheten, slik Goddard et al. (2016) påpeker. De argumenterer for at en organisering knyttet til den akademiske kjernen kan bidra til å videreutvikle universitetet som senter for læring og kunnskapsproduksjon, mens en dekopling av undervisning fra regionalt engasjement ikke bidrar til det (Goddard et al., 2016). Utfordringen er om de som har regionalt ansvar, kan samskape en felles strategi, eller om det blir to ulike tiltak som lever side om side i organisasjonen, eller om de konkurrerer med hverandre.

Det er for tidlig å trekke noen endelig konklusjon om dette blir institusjonalisert, og om det skjer ved begge campusene eller om det blir etablert en arbeidsdeling mellom de to campusene. SV 420 har klart å engasjere både vitenskapelig personale og studenter fra flere fakulteter. Engasjement av interdisiplinær kunnskap ved universiteter er etterlyst, men det som ofte ikke kommer frem i diskursen, er den økonomiske og organisatoriske siden ved denne involveringen. Tverrfaglige emner er mer krevende både organisatorisk og økonomisk enn de vanlige emnene som tilbys i dag. Per i dag er både vitenskapelig personale og studenter fra begge campusene involvert i SV 420, selv om hovedvekten av begge gruppene er fra Campus Kristiansand. Campus Grimstad, som har en hovedvekt av ingeniør- og sykepleierutdanningen, har tradisjonelt hatt mest kontakt med næringslivet og offentlig sektor i regionen og med 
vertskapskommunen Grimstad. Organiseringen av det regionale engasjementet kan ses på som et forsøk på å øke det regionale engasjementet ved Campus Kristiansand.

Casen bidrar også til teoretisk lærdom. For det første viser den at regionalt engasjement kan integreres i undervisning og ikke trenger å organiseres som en tredje oppgave, slik mye av diskursen om universitetets roller drøfter. Denne teorien er utviklet i land med mer liberalistiske økonomiske systemer, som i Storbritannia og USA, men gjort universell gjennom teoretiske bidrag. Tett knyttet til begrepet den tredje rollen er nemlig begrepet tredje inntektsstrøm, som er viktig for universiteter i disse landene, som ikke har den solide finansieringen fra staten som norske universiteter har. Organiseringen av tredjerollen for å sikre en inntektsstrøm til universiteter gir mening i en slik kontekst. I en norsk kontekst med solid statlig finansiering er det ikke like nødvendig, i hvert fall ikke på det nåværende tidspunkt. Når universiteter i en norsk kontekst, som UiA, velger både å integrere regional interaksjon i undervisning og etablere den som en tredje rolle, kan det tolkes som et forsøk på en tilpasning til en fremtidig situasjon der regionale aktører etter hvert må betale for å samskape kunnskap med UiA. Det kan også bety at integreringen av regionalt engasjement i kjernen forsvinner og en får en situasjon der regionalt engasjement er organisert som en tredje oppgave adskilt fra kjerneoppgavene, med de følger det kan få for kunnskapsutvikling.

Det andre teoretiske poenget er knyttet til de fire formene av den regionale rollen som ble utviklet og anvendt i dette kapitlet. De fire formene for regionalt engasjement kombinerer universitetets regionale rolle med to forskjellige måter å skape kunnskap på. Anvendt på strategiplanene til UiA bidro de til å identifisere en institusjonell endring i regionalt engasjement fra 1995 og til i dag. De fire formene er tydelige og kan brukes for å analysere endring i regionalt engasjement over tid. En svakhet ved studien er at fokuset kun var på strategiplanene og det som ble uttrykt i dem. Universitetets praksis kan imidlertid avvike fra det som er uttalt i disse planene. En studie av universitetets praksis over tid er imidlertid en svært omfattende oppgave og har ikke vært innenfor rammen av denne studien. En svakhet med denne gjennomgangen er at den ikke fokuserer 
på hva UiA faktisk har engasjert seg i, men bare på hva som er uttrykt i strategiplanen. Det har imidlertid ikke vært tid til å gjøre noe grundigere studium av hva slags relasjoner den enkelte ansatte ved UiA har med regionale aktører.

Styrken til de fire formene for regionalt engasjement er at de setter fokus på hvordan kunnskap skapes i møtet mellom representanter fra universitetet og representanter fra regionen. Denne studien har vist at kunnskap kan samskapes mellom studenter og regionale aktører. Studien har fulgt en formell ovenfra og ned-strategi når det gjelder identifisering av regionalt engasjement. Ulempen med denne strategien er at den ikke fanger opp det som skjer av uformelt regionalt engasjement knyttet til den akademiske kjernen.

Jeg vil avslutte med å si at det er behov for studier som reflekterer hvordan kunnskap skapes mellom studenter, vitenskapelig personale og regionale aktører over tid. En slik studie vil ikke bare få fram institusjonell endring, men også vise hvordan institusjonell læring skjer mellom universitetet og regionale aktører. Det er med andre ord behov for mer forskning om det som skjer på innsiden av universiteter når det gjelder regionalt engasjement, og hvordan kunnskap skapes i disse møtene.

\section{Referanser}

Asheim, B. T., Smith, H. L. \& Oughton, C. (2011). Regional innovation systems: Theory, empirics and policy. Regional Studies, 45(7), 875-891.

Bokmålsordboka. (2018a). Samarbeid. Hentet fra https://ordbok.uib.no/perl/ordbok. cgi?OPP=samarbeid\&ant_bokmaal=5\&ant_nynorsk=5\&begge $=+\&$ ordbok=begge

Bokmålsordboka. (2018b). Samskaping. Hentet fra https://ordbok.uib.no/perl/ ordbok.cgi?OPP=samskaping

Boyer, E. L. (1990). Scholarship reconsidered: The priorities of the professoriate. Princeton, NJ: Carnegie Foundation for the Advancement of Teaching.

Breen, O. \& Jahr, E. H. (2017). Universitetet i Agder 10 år - med tradisjonar tilbake til 1828. Kristiansand: Universitetet i Agder.

Clark, B. R. (1998). Creating entrepreneurial universities: Organizational pathways of transformation. Oxford: IAU Press and Pergamon.

Clark, B. R. (2004). Sustaining change in universities: Continuities in case studies and concepts. Berkshire: Society for Research into Higher Education \& Open University Press. 
Cooke, P. (1992). Regional innovation systems: Competitive regulation in the new Europe. Geoforum, 23(3), 365-382.

Etzkowitz, H. (1983). Entrepreneurial scientists and entrepreneurial universities in American academic science. Minerva, 21(2), 198-233.

Gibbons, M., Limoges, C., Nowotny, H., Schwartzmann, S., Scott, P. \& Trow, M. (1994). The new production of knowledge - the dynamics of science and research in contemporary societies. London: Sage.

Goddard, J., Hazelkorn, E., Kempton, L. \& Vallance, P. (2016). Introduction: Why the civic university? I J. Goddard, E. Hazelkorn, L. Kempton \& P. Vallance (Red.), The civic university: The policy and leadership challenges (s. 3-15). Croydon: Edwar Elgar.

Gulbrandsen, M. \& Nerdrum, L. (2009). University-industry relations in Norway the Norwegian Case. I J. Fagerberg, D. C. Mowery \& B. Verspagen (Red.), Innovation, path dependency and policy (s. 297-326). Oxford: Oxford University Press.

Høgskolen i Agder. (1994). Mot år 2000 - Strategisk plan for Høgskolen i Agder. Kristiansand: Høgskolen i Agder.

Høgskolen i Agder. (2004). Problemnotat Strategiplan Høgskolen i Agder fra 2006. Kristiansand: Høgskolen i Agder.

Jensen, M. B., Johnson, B., Lorenz, E. \& Lundvall, B. Å. (2007). Forms of knowledge and modes of innovation. Research Policy, 36, 680-693.

Karlsen, J. (2007). The regional role of the university: A study of knowledge creation in the agora between Agder University College and regional actors in Agder. Trondheim: Norwegian University of Science and Technology.

Krčmářová, J. (2012). The third mission of higher education institutions: Conceptual framework and application in the Czech Republic. European Journal of Higher Education, 1(4), 315-331.

Lucas, W., Cooper, S., Ward, T. \& Cave, F. (2009). Industry placement, authentic experience and the development of venturing and technology self-efficacy. Technovation, 29, 738-752.

Macmillan Dictionary. (2018). Co-creation. Hentet fra https://www. macmillandictionary.com/dictionary/british/co-creation

Molas-Gallart, J. \& Castro-Martínez, E. (2007). Ambiguity and conflict in the development of 'Third Mission' indicators. Research Evaluation, 16(4), 321-330. https://doi.org/10.3152/095820207X263592

Molas-Gallart, J., Salter, A., Patel, P., Scott, A. \& Duran, X. (2002). Measuring third stream activities. Brighton: SPRU.

Nowotny, H., Scott, P. \& Gibbons, M. (2001). Re-thinking science: Knowledge and the public in an age of uncertainty. Cambridge: Polity Press. 
OECD. (1999). The response of higher education institutions to regional needs. Paris: OECD

OECD. (2007). Higher education and regions: Globally competitive, locally engaged. Paris: OECD

Philpott, K., Dooley, L., O’Reily, C. \& Lupton, G. (2011). The entrepreneurial university: Examining the underlying academic tensions. Technovation, 31(4), 161-170. https://doi.org/10.1016/j.technovation.2010.12.003

Pinheiro, R., Benneworth, P. \& Jones, G. A. (Red.). (2012). Universities and regional development: A critical assessment of tensions and contradictions. Milton Park and New York: Routledge.

Regeer, B. J. \& Bunders, J. F. G. (2009). Knowledge co-creation: Interaction between science and society - a transdisciplinary approach to complex societal issues. Amsterdam: VU University Amsterdam, Athena Institute.

Slaughter, S. \& Rhoades, G. (2004). Academic capitalism and the new economy: Markets, state, and higher education. Baltimore/London: Johns Hopkins University Press.

Trippl, M., Sinozic, T. \& Smith, H. L. (2015). The role of universities in regional development: Conceptual models and policy institutions in the UK, Sweden and Austria. European Planning Studies, 23(9), 1722-1740. https://doi.org/10.1080/096 54313.2015.1052782

Universitetet i Agder. (2005). Mot 2010-Strategiplan. Kristiansand: Universitetet i Agder.

Universitetet i Agder. (2012). Strategi for Universitetet i Agder: Vedtatt 14.10.2009 og revidert 18.9.2012. Kristiansand: Universitetet i Agder.

Universitetet i Agder. (2016). Strategi 2016-2020. Kristiansand: Universitetet i Agder. Universitetet i Agder. (2018b). Strategiprosjekt samfunnsengasjement og nyskaping. Kristiansand: Universitetet i Agder.

Universitetet i Agder. (2019a). Emnebeskrivelse SV 420 - UiA Samskaping OpenLab. Kristiansand: Universitetet i Agder.

Universitetet i Agder. (2019b). Stillingsannonse. Hentet fra: https://www.jobbnorge. no/ledige-stillinger/stilling/162507/lab-leder-tjenestedesigner-til-uia-colab

Uyarra, E. (2010). Conceptualizing the regional roles of universities: Implications and contradictions. European Planning Studies, 18(8), 1227-1246. https://doi. org/10.1080/09654311003791275

Watson, D., Hall, L. \& Tazzyman, S. (2016). Trick or treat: Academic buy-in to third stream activities. Industry and Higher Education, 30(2), 155-167. https://doi. org/10.5367/ihe.2016.0301

Yin, R. K. (2013). Case study research: Design and methods. Thousand Oaks: Sage Publications. 



\title{
KAPITTEL 9
}

\section{Et paradigmeskifte sett nordfra}

\section{Linda Helén Haukland}

\section{Nord universitet}

\begin{abstract}
In this chapter, the integration of the Norwegian higher education field is analyzed in regard to the implementation of two reforms in Nordland County: the college reform in 1994 and the structural reform in 2015. The first resulted in two autonomous higher education institutions: Nesna College and Bodø University College. The last was a result of geographical considerations in connection with the location and autonomy of higher education institutions, here called 'the geographical paradigm' being replaced with quantitative measures of quality in a new academic paradigm. The structural reform led to the amalgamation of the two and, including Sør-Trøndelag University College, the formation of North University in 2016. One key question is how this paradigm shift occurred and in what way it affected the higher education institutions in Bodø and Nesna.
\end{abstract}

Keywords: teacher education, Nesna, Bodø University College, Nord University, Nordland county, higher education reforms in Norway

\section{Introduksjon}

En trend i utviklingen av høyere utdanning i Europa har vært en økende integrering (Bleiklie, 2003; Kyvik, 2009). Fusjonene mellom Høgskolen i Nesna og det fem år gamle Universitetet i Nordland i 2016 er et eksempel på dette. Sammen med Høgskolen i Nord-Trøndelag ble disse til Nord universitet, med rundt 12 ooo studenter og 1200 ansatte. ${ }^{1}$ I dette kapitlet

1 Der ikke annet er nevnt, vil lærerutdanningen på Nesna i dette kapitlet brukes som betegnelse på høyere utdanningstilbud på Nesna. Nordland distrikthøgskole ble opprettet i 1971 og ble til Høgskolesenteret i Nordland i 1986. I 1994 ble Høgskolen i Bodø etablert, en fusjon mellom høgskolesenteret, Nordland sykepleierhøgskole og Bodø lærerhøgskole, som i 2011 ble til Universitetet i Nordland.

Sitering av dette kapitlet: Haukland, L. H. (2019). Et paradigmeskifte sett nordfra. I J. P. Knudsen \& T. Lauvdal (Red.), Geografi, kunnskap, vitenskap. Den regionale UH-sektorens framvekst og betydning (s. 219-240). Oslo: Cappelen Damm Akademisk. https://doi.org/10.23865/noasp.73.ch9.

Lisens: CC BY 4.0 
skal jeg se nærmere på sentrale prosesser som både hindret fusjon mellom høgskolemiljøene i Bodø og Nesna i forbindelse med høgskolereformen i 1994, og som ledet fram til fusjonen i 2016. Hva skjedde mellom disse reformene som førte til to så ulike utfall?

\section{Teoretisk tilnærming, sentrale begreper og empiri}

Jeg tar utgangspunkt $i$ et organisatorisk institusjonelt perspektiv fordi det kan belyse endringsdynamikker mellom det regionale, det nasjonale og det europeiske nivået. Her ses aktørene som del av institusjonaliserte organisatoriske felt bestående av flere sektorer med egne institusjonelle logikker (DiMaggio \& Powell, 1983; Bleiklie, 2007, s. 100 ff.; Meyer et al., 2008, s. 187; Scott, 2014, s. 11, 62). Feltbegrepet gjør at mikro- og makroperspektivet kan anvendes i samme analyse, og at kamper mellom logikker i de ulike sektorene avdekkes (Thornton \& Ocasio, 2008, s. 100; Haukland, 2018, s. 18). Siden beslutninger på ett nivå tolkes og implementeres forskjellig på et annet, kan man ikke vite hvordan for eksempel reformer vedtas og virker, bare ved å studere sentrale dokumenter (Musselin, 2000). Samspill og interessekonflikter mellom nivåene er ifølge Christine Musselin (2000) avgjørende for å forstå endringsdynamikkene på feltet (s. 296).

Høyere utdanningssystem kan ses som ulike kombinasjoner av både en hierarkisk orden, der akademisk status avgjør rangeringen mellom institusjonene, og en organisk orden, der relasjonen mellom institusjonene blir definert av ulike funksjoner og oppgaver gjennom spesialisering (Bleiklie, 2003, s. 342). En organisk orden vil ifølge Ivar Bleiklie fremdeles påvirke utviklingen selv der et formelt hierarkisk system er etablert. Høyere utdanningssystem defineres i tillegg av høgskolers og universiteters relasjon til staten og til samfunnet (Kyvik, 2009). I dette kapitlet står relasjonen mellom institusjonene i fokus.

Distriktshøgskolene utfordret det Trow (1974) har kalt universitetenes tradisjonelle elitistiske kultur og praksis, et uttrykk for «the increasingly strong egalitarian values of Western society» (s. 59). Guy Neave (1996) har påpekt at utdanningssystemer er et uttrykk for «that 
civilisation's central norms» (s. 408; Schwartzman, 2007, s. 53). Utviklingen kan ses som et uttrykk for at nye normer basert på egalitære verdier kom til overflaten i et nytt utdanningssystem. Dette markerte ifølge Kyvik (2009) slutten på en periode med differensiering og mangfold drevet fram av staten, og av ulike interesser, og begynnelsen på en periode der institusjonene selv drev fram den fragmenterte ekspansjonen (s. 58). Det nasjonale prosjektet ble på mange måter overført til et distriktspolitisk program med rom for regionale identiteter (Haukland, 2018b, s. 19, 72, 88). Jeg skal her løfte fram tre sentrale trekk ved det jeg har kalt "det geografiske paradigmet», som alle springer ut fra egalitære verdier.

For det første ble høyere utdanning en rettighet som skulle gjøres gjeldende også for ungdom i nasjonens periferier (Monsen, 1993, s. 143, 144; Wold Johnsen, 1999, s. 33; Enebakk, 2009, s. 124). Dermed fikk geografi avgjørende betydning for hvor utdanningstilbud skulle ligge. For det andre måtte utfordringer knyttet til kompetansearbeidskraft i velferdsstatens yrker finne sin løsning. Selv om Nordland rekrutterte flere lærerskoleelever enn de fleste andre fylker, ble nordlandsungdommen i stor grad værende sørpå etter endt utdanning. Geografisk plassering av studiesteder ble dermed viktig for å sikre velferdstjenester i fylket. For det tredje innebar etableringen av distriktshøgskolene en innføring av en ny høgskolekultur der akademikere utviklet kunnskap med utgangspunkt i regionen. Distriktshøgskolene representerte på mange måter en motekspertise, som ifølge Gunnar Yttri (2008) skulle «sikra at bygde-Noreg ikkje var offer for sentralmakt og økonomisk utbytting» (s. 15). Dette skapte et krysspress mellom en arbeidsdeling basert på regionale forskjeller og ulike regionale mandat, og en fagutvikling basert på akademisk kompetanse (Fulsås, 200o). De regionale høgskolestyrene fikk et for begrenset mandat til å ta overordnede grep om utviklingen (Bakken \& Hveding, 1991). Distriktshøgskolene ble dermed både det geografiske paradigmets forkjempere og på lengre sikt dets sterkeste utfordrere.

Reformene i perioden var ikke bare årsak til endringer, men også et resultat av dem (Bleiklie, Høstaker \& Vabø, 2000, s. 285; Kyvik, 2009, s. 7). Martin Trow (2010) har pekt på at sterk vekst i antall studenter 
undergraver gjeldende praksiser og skaper nye behov (s. 562). ${ }^{2}$ Mot dette har Burton Clark hevdet at tidlig institusjonalisering også spiller inn på utviklingen i større grad enn forventet, noe som gjør vekst til en av flere endringsmekanismer (Clark, 1983, s. 185). Han hevder at tidlig institusjonalisering virker hindrende på endring. Likevel var det ifølge Kyvik (2009) veksten i antall studenter som var den viktigste årsaken til endring i tiden som fulgte (s. 36,72$){ }^{3}$

For å se nærmere på fusjonsprosessene i Nordland i 1994 og i Nordland og Trøndelag i 2016 baserer jeg meg på arkivstudier ved Nord universitet, Arkiv Bodø og Nord universitet, Arkiv Nesna samt arkivene for Nesna lærerhøgskole og Nordland distriktshøgskole ved Statsarkivet i Trondheim i tillegg til rundt 40 intervjuer av sentrale personer tilknyttet sentral ledelse og fakultetsledelse ved Høgskolen i Bodø og Høgskolen i Nesna i perioden 1994-2016. I tillegg drar jeg veksler på aktuelle stortingsmeldinger og sentrale dokumenter fra perioden 1965-2015 samt sekundærlitteratur. ${ }^{4}$

\section{Presentasjon av høgskolene i Nesna og Bodø}

Høgskolen i Nesna var i utgangspunktet en såkalt provinsskole, etablert som lærerutdanning i 1918 for å bøte på lærernøden i fylket og et sentralt ledd i å bygge det nasjonale prosjektet i nord. ${ }^{5}$

Statens lærerskoleklasser ble etablert som et krisetiltak i Bodø i 1951. Dette flyttet tyngdepunktet for høyere utdanning i fylket fra Nesna i sør til Bodø midt i fylket. I tiden som fulgte, ble det etablert en arbeidsdeling mellom de to lærestedene i tråd med en organisk orden; lærerskoleelevene

2 Wold Johnsen, 1999, s. 14. Utviklingen av høyere utdanning etter andre verdenskrig og fram til begynnelsen av 1990-tallet i Norge bar ifølge Ingunn Monsen preg av veksten i det totale antallet studenter og reformene som er gjennomført som et resultat av denne (Monsen, 1993, s. 143). Slike regjeringsnedsatte utvalg har hatt stor påvirkning på utviklingen i hele perioden (Kyvik, 2009, s. 34). For videre utdypning av opptakten til distriktshøgskolene, se kapitlet skrevet av Peter Arbo om universitet og region i denne boka.

3 Se også kapitlet skrevet av Per Olaf Aamodt og Lars Lyby i denne boka.

4 En bredere framstilling av prosessene presenteres i Haukland, 2015; Haukland, 2018; og Haukland, 2018 b.

5 Se Haukland 2018b. Poenget med en utdanning utenfor sentrale strøk på denne tiden var at elevene skulle unngå å bli bedervet og distrahert av det byene hadde å by på. 
på Nesna ble forberedt på hverdagen i fådelt skole i Bygde-Norge, mens elevene i Bodø fikk en utdanning mer tilpasset sentrale strøk. I 1965 bekreftet Stortinget denne arbeidsdelingen gjennom å vedta et desentralisert lærerskolemønster. ${ }^{6}$ I 1968 ble Universitetet i Tromsø etablert, og Nord-Norges første universitet åpnet dørene for sine første kull med studenter samme høst som den nye Nordland distriktshøgskole mottok sine første kull i Bodø i 1971 (Solhjell, 1977, s. 96, 97; Fulsås, 1993, s. 170; Haukland, 2015, s. 39). Nordland fylke hadde lavest utdanningsnivå i landet ved utgangen av 1960-årene, og det ble knyttet store forventninger til den nye distriktshøgskolen.7 I 1986 ble institusjonen reetablert som Høgskolesenteret i Nordland for å markere at den tilbød siviløkonomutdanning og, i likhet med Høgskolesenteret i Rogaland, hadde tilsatt professor. ${ }^{8}$ Mens distriktshøgskolene i Agder og Rogaland hadde universitetsplaner, var det ingen ved den nye Campus Mørkved i Bodø som vurderte dette. ${ }^{9}$

De to nevnte høgskolene i sør ble etablert før Nordland distriktshøgskole og bidro til at fagutviklingen skjedde i høyt tempo i prøveperioden (Haukland, 2015, s. 38 ff.). Ekspansjonen utfordret Universitetet i Tromsøs

6 Nasjonalbibliotekets digitalarkiv. Stortingsforhandlinger $1964 / 65$ vol. 109 nr. 7 b, s. 2780 ; Østerud et al., 2015, s. 75.

7 Nasjonalbibliotekets digitalarkiv. Stortingsforhandlinger 1978/1979 vol. 123 nr. 7c, 3553, Nord universitet, arkiv Bodø. Fygle 1995, s. 7.

8 Distriktshøgskolene i Agder (1977), Rogaland (1980) og Nordland (1983) fikk høyere studier i sin portefølje. Det åpnet opp for at de også tilsatte professorer. Etableringen av et høgskolesenter i Bodø anses for å være et av de viktigste gjennombruddene i institusjonsutviklingen (Intervju Rasch; Haukland, 2015). Dette var både fordi fagmiljøet ved siviløkonomutdanningen etter hvert kom til å bære den første doktorgradsutdanningen ved institusjonen, og fordi den rekrutterte studenter fra hele landet. I 1987 ble journalistutdanningen etablert for å avlaste journalistutdanningene sørpå og møte behovene for kompetente journalister i regionen, noe som også bidro til å profilere det nye høgskolesenteret nasjonalt (Haukland, 2015, s. 60).

9 Ruud-komiteens innstilling fra 1965 om etableringen av Universitetet i Tromsø målbar at det kunne være et spørsmål om tid når lærestedet hadde en slik faglig bredde og kvalitet at det kunne kalles et universitet. Tanken om at høgskoler kunne bli universiteter, var utgangspunkt både for universitetsprosessene i Stavanger og Agder og for universitetsprosessen i Bodø (Kristian Ottosen til Sunnmørsposten 07.10.1967, sitert i Wold Johnsen, 1999, s. 16; Fulsås, 200o, s. 92). Disse krevde både to definerte sektorer og overgangsordninger mellom dem. Et viktig gjennombrudd kom da Distriktshøgskolene i Agder, Rogaland og Nordland fikk tilsatte professorer. Akademisk drift var en viktig drivkraft i deler av fagmiljøene allerede fra etableringen av distriktshøgskolene, som satte bremser på det institusjonelle mangfoldet distriktshøgskolene i utgangspunktet skulle representere på feltet. For at disse skulle være en egen type utdanningsinstitusjon, måtte de ifølge Narve Fulsås hatt et eget utdanningsoppdrag med særskilte kriterier for avansement i tråd med en institusjonell desentraliseringstanke (Fulsås, 200o, s. 396). 
rolle som landsdelsuniversitet på hovedsakelig tre måter. For det første fungerte Nordland distriktshøgskole som en magnet på nordlandsungdommen, mens få av dem valgte universitetet lenger nord (Fulsås, 1993; Haukland, 2015, s. 45). At 58,5 prosent av nordnorske studenter ved landets universiteter og høgskoler kom fra Nordland i 1971, og at fylket hadde flere innbyggere enn Finnmark og Troms til sammen, hører med til dette bildet (Haukland, 2015, s. 45).

Dette ledet til den andre utfordringen sett fra Tromsø: Kompetansebehovet var størst i Nordland. Nordland distriktshøgskoles profil var designet for å møte behovet for kompetansearbeidskraft og var dermed en del av en geografisk desentraliseringsprosess, mens Universitetet $\mathrm{i}$ Tromsø skulle sikre ungdom i nord tilgang på høyere utdanning som en del av en institusjonell desentralisering i universitetssektoren. Dette skapte en sterk innovasjonskultur i Bodø-miljøet og sterke koblinger til næringslivet og regionale myndigheter samt stortingspolitikerne på nordlandsbenken.

For det tredje vant Nordland distriktshøgskole viktige lokaliseringskamper om høyere utdanningstilbud i Nord-Norge. Dette kan ses på som en kamp mot Universitetet i Tromsøs hegemoni i landsdelen. Siviløkonomutdanningen var et initiativ fra Nordland distriktshøgskole som Universitetet i Tromsø tok opp kampen for å realisere slik at NordNorge ikke skulle få to «mini-universitet» (Fulsås, 1993, s. 176). Tromsø var innstilt som lærested av komiteen, og bare Venstres gruppe sto samlet bak en lokalisering i Bodø, men en skarp og lang debatt i Stortinget førte til at Bodø fikk studiet, med 101 mot 30 stemmer (Haukland, 2015, s. 50). Gjentatte ganger sto de to lærestedene imot hverandre i lokaliseringsstrider. Disse forholdene utfordret tanken om en felles nordnorsk identitet på det høyere utdanningsfeltet. Det var snarere snakk om en landsdelsidentitet ved Universitetet i Troms $\varnothing$ og en nordlandsidentitet i høgskolemiljøet i Bodø.

I 1981 ble lærerutdanningen i byen oppgradert til høgskole, sykepleierutdanningen ble høgskole fem år senere. Det var disse tre høgskolene som i forbindelse med høgskolereformen i 1994 fusjonerte til Høgskolen i Bodø. Etableringen skapte et nytt tyngdepunkt for høyere utdanning i landsdelen i tillegg til Universitetet i Tromsø. 
Som eneste lærerhøgskole i landet bevarte Nesna lærerhøgskole sin autonomi og ble til Høgskolen i Nesna i 1994, noe som innebar at den tidligere lærerhøgskolen skulle tilby en bredde av høgskolestudier til sin region. Rundt årtusenskiftet offentliggjorde Høgskolen i Bodø sine universitetsplaner etter å ha blitt, sammen med Høgskolen i Stavanger og Høgskolen i Agder, lansert som aktuell universitetskandidat i Stortinget (Haukland, 2015, s. 143). Høgskolen i Bodø ble akkreditert som universitet fra 1. januar 2011.

For Høgskolen i Nesna representerte Bodø-miljøet en stadig trussel mot høgskolens autonomi og ressurstilgang. Selv om høgskolen hadde en sterk lærerutdanning, var det en krevende øvelse å skulle utvide fagporteføljen og bli en høgskole med samme krav til studentvolum og kvantitative kvalitetsmål som andre norske høgskoler den ikke kunne sammenlignes med. Høgskolen blir slik et eksempel på hvordan utviklingen av norsk høyere utdanning påvirket de minste høgskolene. Til tross for sterk motstand og en intens kamp for å unngå fusjon ble Høgskolen i Nesna til Nord universitet, studiested Nesna fra 1. januar 2016.

\section{Kampen for egen autonomi}

Etter høgskolereformen var det bare to norske fylker som hadde mer enn én høgskole. Nordland fikk beholde Høgskolen i Narvik i nord og Høgskolen i Nesna i sør, i tillegg til Høgskolen i Bodø. ${ }^{10}$

Da Bologna-prosessen skulle implementeres på det norske utdanningsfeltet gjennom kvalitetsreformen i 2003, var et av målene en sterkere institusjonell autonomi. Denne europeiske integreringen, som også ble brukt for å løse nasjonale utfordringer, møtte her et sterkt behov på regionalt nivå (Stensaker, 2006).

Lærerutdanningen på Nesna hadde ofte forsvart sin eksistens, men kampens kjerne hadde gradvis beveget seg fra kravet om å skaffe distriktene motekspertise til kravet om å bevare institusjonens 
selvstendighet. Høgskolen i Nesna var som nevnt et uttrykk for at en organisk orden fortsatt var virksom gjennom spesialisering, men høgskolen arbeidet samtidig for å etablere seg som en høgskole i tråd med kravet om et bredere fagtilbud. Den intense kampen for en moderne campus på Nesna i perioden 1997 til 2006, kan ses på som et ledd i kampen for å overleve som selvstendig høgskole (Haukland, 2018b, 138 ff.). Den nye campusen var for mange et signal om at høgskolen var sikret en framtid.

Kampen for selvstendighet førte til at de rurale høgskolene gjorde mindre motstand mot endringene kvalitetsreformen bar med seg, endringer som senere skulle snu opp ned på hele feltet og etter hvert gjøre ende på alle høgskoler i Nord-Norge unntatt den minste av dem, med kanskje størst symbolsk kapital: Samisk høgskole. Disse høgskolene ble dermed, slik Yttri (2008) har påpekt, «bølgeryttere» som surfet med sentraliseringsvindene i høgskolesektoren (s. 94, 103, 104, 105). ${ }^{11}$

Høgskolen i Nesna bevarte lærerutdanningens profil, men skulle fylle kravene til ordinære høgskoler og måtte utvide studietilbudet. Et eksempel på Høgskolen i Nesna som «bølgerytter» i kampen for å bevare autonomien, er at den fulgte Stjernø-utvalgets anbefaling fra 2008 og innførte en ny styringsordning med tilsatt rektor og ekstern styreleder i $2011 .^{12}$ Trusselen mot høgskolens selvstendighet dersom Høgskolen i Bodø fikk universitetsstatus, hører med til dette bildet; det nye universitetet gikk i gang med fusjonsforhandlinger med høgskolene i Nesna, Narvik og Harstad så snart universitetsstatusen var sikret høsten 2010. ${ }^{13}$ Enhetlig ledelse skulle i utgangspunktet gi en mer styringsdyktig ledelse, men samarbeidet med ekstern styreleder, tidligere rektor ved Universitetet i Stavanger Aslaug Mikkelsen, ble vanskelig. Ifølge rektor Sven Erik Forfang arbeidet Mikkelsen målrettet for å få til en fusjon med Høgskolemiljøet i Bodø (Intervju 09.02.2018).

På kort sikt så det ut som om høgskoler som Høgskolen i Nesna styrket seg; både ny campus og tidsriktig ledelse var på plass. Men i forbindelse

\footnotetext{
11 Yttri anvender begrepene på utviklingen ved Sogn og Fjordane distriktshøgskole i perioden 1975 til 1994.

12 Nord universitet, Arkiv Nesna. Høgskolen i Nesna 2011-2012.

13 Intervju Stig Fossum og Pål Pedersen 29.03.2019.
} 
med høgskolereformen og kvalitetsreformen mistet de vitenskapelig ansatte sin makt til sentraladministrasjonen både ved høgskoler og universiteter, og den politiske kanalen ble stadig mindre tilgjengelig gjennom utviklingen av ulike kvalitetssikringssystemer, som kulminerte med etableringen av NOKUT i 2003. Ifølge sluttrapporten for evalueringen av høgskolereformen hadde utviklingen gått mot at:

Beslutninger som tidligere ble debattert i breie fora er flyttet inn på andre og mer uformelle arenaer. Disse arenaene har videre skiftet karakter, fra å være kollegiale til å bli strukturert som medvirkningsarenaer ut fra forholdet mellom arbeidstaker og arbeidsgiver (Norges forskningsråd, 2007, s. 38).

Med til dette bildet hører det at de tre sterkeste høgskolene, med størst potensial til å opponere mot utviklingen, aspirerte til universitetsstatus. De ble dermed også mer opptatt med å innfri krav enn å trenere dem. De hadde kjempet en lang kamp for at faglighet skulle legges til grunn for hvilke utdanningstilbud de kunne tilby, ikke geografi. En milepæl var da statsråd Lilletun understreket at det er «det faglege og ikkje geografi eller namn som skal avgjere dette» i forbindelse med spørsmålet om Bodø skulle bli universitetsby eller ikke (Stortingets spørretime 20.10.1999). ${ }^{14}$ I realiteten var Lilletuns prosjekt å bygge ut universiteter i regionene, ikke å innføre faglighet, men dette var et grep for å få etablert forskerutdanninger ved høgskolene, som var nødvendig for å kvalifisere til universitetstittelen. Dermed ble også de sterkeste høgskolene i sektoren «bølgeryttere».

Det geografiske paradigmet var svekket. For å kunne oppnå sine egne, individuelle mål, og sikre og styrke sin individuelle selvstendighet, krevde høgskolene å bli behandlet på like faglige vilkår med universitetene. Svaret på dette kravet fra nasjonalt nivå ble en sterkere hierarkisk orden der kvalitet og forskning samt antall førstevalgsstudenter og studenter med fullførte studieløp var avgjørende faktorer. Standardiseringen som skulle ivareta likhetskravet, la samtidig til rette for integreringen av feltet, og dermed også for framtidige fusjoner. 


\section{Kravet om faglighet}

Kravet om likhet innebar nødvendigvis også et krav om kvalitet, noe både de høyere utdanningsinstitusjonene og myndighetene var enige om. Kvalitetssikring ble navet som skulle sikre at utviklingen gikk i retning av sterkere forskningsmiljøer og akademiske prestasjoner. Forskere innenfor høyere utdanning har trukket fram kvalitetssikring og akkreditering som den sterkeste endringsfaktoren på feltet i tillegg til internasjonalisering (Kogan \& Hanney, 2000, s. 240; Stensaker, 2006, s. 44; Witte, Wende \& Huisman, 2008, s. 219, 228). Gjennom kvalitetssikringen ble ledelsens mål forent med de vitenskapelig ansattes, fordi forskningen både sikret institusjonens økonomiske situasjon og autonomi og den enkelte vitenskapelig ansattes karrierevei.

Det var sterk lærernød i regionen, der spesielt de fådelte skolene i bygdene manglet lærerkrefter. Høgskolen i Nesna tilbød studier som møtte sentrale behov i regionen, og siden høgskolen lå på et tettsted og ikke i en by, ble denne profilen opprettholdt gjennom blant annet øvingsskolen. Etter etableringen av NOKUT hadde imidlertid høgskolen ikke lenger grep om $h v a$ den skulle gjøre, eller hvordan den skulle løse sitt oppdrag. En sterkere institusjonell selvstendighet som høgskole ble dermed en tvangstrøye, der man måtte innfri strenge krav til virksomheten snarere enn å boltre seg fritt på eget revir. Da kvalitetskravet om gjennomstrømning av et gitt antall kandidater på hvert studium kom, gjennom det såkalte tellekantsystemet i 2006, ble denne dimensjonen ytterligere aktualisert. Kvalitet var gått fra å være det motsatte av kvantitet til å bli en målbar størrelse.

Høgskolen valgte riktignok selv hvilke studietilbud den skulle opprette, men fikk ikke drifte dem videre dersom kandidater eller resultater uteble. Studietilbudene høgskolen tilbød i utlandet, hadde både kandidater og resultater på plass, men ble likevel nedlagt fordi de ikke passet inn i høgskolens regionale profil (Haukland 2018b, s. 140). Den hadde et sterkt nedslagsfelt også i Trøndelag, men ble målt bare på rekrutteringen av studenter fra Nordland. Figur 1 og tabell 1, med tall for uteksaminerte kandidater fordelt på periode og hjemfylke, viser at høgskolens nedslagsfelt var stort også sør for fylkesgrensa. 


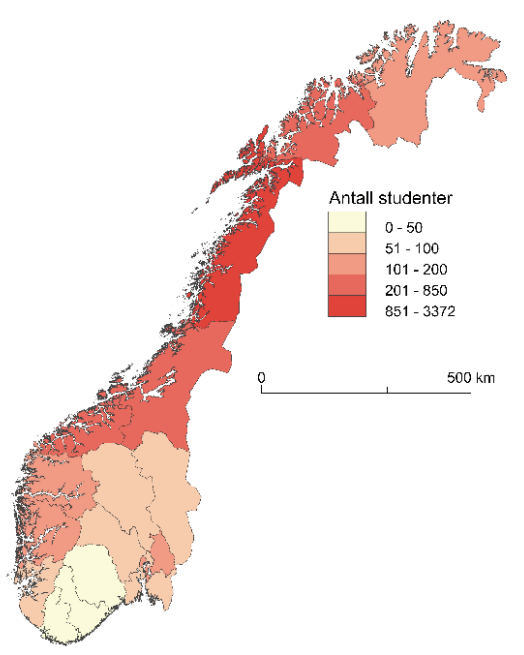

Figur 1. Uteksaminerte lærere fordelt på hjemfylker 1918-201715

\begin{tabular}{|l|c|c|}
\hline Fylke & $\mathbf{1 9 7 1 - 1 9 9 3}$ & $\mathbf{1 9 9 4 - 2 0 1 8}$ \\
\hline Aust-Agder & $0,4 \%$ & $0,5 \%$ \\
\hline Akershus & $3,6 \%$ & $3,6 \%$ \\
\hline Buskerud & $1,9 \%$ & $1,1 \%$ \\
\hline Finnmark & $1,5 \%$ & $0,6 \%$ \\
\hline Hedmark & $1,4 \%$ & $1,3 \%$ \\
\hline Hordaland & $2,3 \%$ & $1,4 \%$ \\
\hline Møre og Romsdal & $3,9 \%$ & $2,7 \%$ \\
\hline Nordland & $55,4 \%$ & $61,7 \%$ \\
\hline Oppland & $1,7 \%$ & $1,2 \%$ \\
\hline Oslo & $2,5 \%$ & $0,9 \%$ \\
\hline Rogaland & $1,0 \%$ & $1,6 \%$ \\
\hline Sogn og Fjordane & $1,0 \%$ & $0,3 \%$ \\
\hline Telemark & $1,5 \%$ & $0,3 \%$ \\
\hline Troms & $4,1 \%$ & $2,6 \%$ \\
\hline Trøndelag & $13,6 \%$ & $16,2 \%$ \\
\hline Vest-Agder & $1,0 \%$ & $0,5 \%$ \\
\hline Vestfold & $1,8 \%$ & $1,1 \%$ \\
\hline Østfold & $1,5 \%$ & $2,4 \%$ \\
\hline
\end{tabular}

Tabell 1. Andel uteksaminerte lærere fordelt på hjemfylker 1971-2017.16

15 Berg kartografi/ Nord universitet 2018. Tidligere publisert i Haukland 2018b. Tallene er basert på lister over uteksaminerte lærere gjennom hele hundreårsperioden, tilgjengelig ved Nord universitet, Arkiv Nesna. Midt-Norge og Nordland skiller seg ut som loererutdanningen på Nesnas cirkumferens for rekruttering av elever og studenter når hele hundreårsperioden ses under ett. Kartet viser fordelingen av studenter fra ulike fylker i absolutte tall.

16 Berg kartografi/ Nord universitet 2018. Upublisert. Fylker med sterkest rekruttering markert med rødt. 
Den regionale dimensjonens rolle som bevarer av lokal kultur og bygdesamfunn avtok i takt med økende krav om at høyere utdanning skulle bidra til økonomisk vekst kombinert med høyere institusjoners krav om likebehandling. Dette tåkela og delvis begravde tidligere distriktspolitiske konfliktlinjer, og gjorde at distriktspolitikken ofte ble «den blinde flekken som utdanningspolitikken ikkje nådde fram til» (Yttri, 2016, s. 70). Høgskolen i Nesna sto svakt fordi institusjonens regionale fokus var mer rettet mot bevaring av små lokalsamfunn enn mot regional vekst og økonomisk utvikling. En rural høgskole som Høgskolen i Nesna var en stemme fra periferien som målbar en ikke-meritterende motkultur. Den hadde kvaliteter som ikke kunne telles ved hjelp av kvantitative kvalitetsmål.

Da Høgskolen i Nesna ble etablert i 1994, fikk institusjonen en direktør, som overtok det administrative ansvaret rektor til da hadde hatt. Gjennom den nye styringsordningen med enhetlig ledelse ved Høgskolen i Nesna i 2011 ble ytterligere makt overført fra de vitenskapelig ansatte til sentraladministrasjonen internt i institusjonen. De kunne ikke lenger velge rektor. En nesten hundre år gammel tradisjon der lærerkreftene hadde arbeidet sammen som «likemenn», ble gradvis byttet ut med en hierarkisk akademisk kultur fundert på individuelle vitenskapelige prestasjoner. Det svekket motkulturen i en institusjon som fremdeles trengte, for å sitere pedagogen Erling Kristvik (1928), «å leve sammen» for å overleve (s. 112; Intervju Sven Erik Forfang 2018; Slagstad, 1998, s. 105, 106).

Høgskolereformen hadde tilført styringsevne, men utfordret samtidig det som hadde vært institusjonens varemerke: en over nitti år gammel samarbeidskultur på tvers av generasjonene mellom studenter og lærere, og i staben mellom likemenn - til beste for regionen både sør og nord for fylkesgrensa. Ekstern styreleder Mikkelsen, som hadde et klart mål om fusjon med Universitetet i Nordland, er et eksempel på at andre interesser enn de regionale var i ferd med å overta. Profesjonsutdanningene var nå en del av de nye regionale høgskolene, og den yrkesfaglige driften var dermed svekket som motkraft. Spesielt var det professoratene som sprengte rammene for det binære utdanningssystemet; at høgskolene hadde tilsatte professorer, gjorde dem i stand til å utvikle forskerutdanninger (Fulsås, 2000, 396).

Høgskolereformen hadde som målå konsolidere det binære utdanningssystemet for å forhindre at høgskoler fikk universitetsstatus, men i realiteten 
la den til rette for overgangsordninger mellom de to sektorene fordi sektorgrensene ble gått opp gjennom at høgskolene ble navngitt i den nye universitets- og høyskoleloven fra 1996 (Universitetsloven, 1995; Haukland, 2018, s. 85). Det var da to klart definerte sektorer og vesentlig færre utdanningsinstitusjoner i høgskolesektoren. Et tydelig binært utdanningssystem kom på plass, men ifølge Kyvik (2009) sprengte akademiseringen det innenfra (s. 56).

Etableringen av Norgesnettet var en viktig del av Høgskolereformen som tok sikte på å bygge et nettverk av samarbeid mellom alle institusjonene på feltet. Relasjonene innad i sektorene og mellom dem skulle styrkes gjennom såkalte regionale og nasjonale knutepunkt, som utgjorde viktige kommunikasjonssentre for samarbeid og fagutvikling. Forutsetningen for Norgesnettet var klart definerte sektorgrenser uten overgangsmuligheter.

Høgskolene var svært aktive for å få tildelt knutepunktsfunksjoner i Norgesnettet, noe som innebar at et fagmiljø tok ansvar for fagutviklingen på regionalt eller nasjonalt nivå. Tildelingen av rundt 30 knutepunkt i 1995 innebar imidlertid en ansvarsfordeling for fagutviklingen det ikke fulgte med penger til.

Høgskolene ble tildelt nasjonale og regionale knutepunkt, noe som styrket akademiseringen, samtidig som grensene i arbeidsfordelingen mellom høgskoler og universiteter ble mer utydelige. Utviklingen gikk i samme retning i Tyskland, Nederland og Frankrike (Witte et al., 2008). Som Gornitzka (1999, s. 18) har påpekt, skaper det et større institusjonelt handlingsrom når nasjonalt nivå ikke følger opp egne reforminitiativ. Det var dette som nå skjedde.

Et element i utdanningssystemet som var med på å styrke integrasjonen av feltet og svekke sektorgrensene, var selve ordningen med doktorgradsutdanninger. Ved de etablerte universitetene hadde fokuset på doktorgrader ifølge Bleiklie og Roar Høstaker (2004) historisk sett vært lavt, og innføringen av doktorgradsprogram var en del av standardiseringsprosessene på feltet (s. 223, 229). På 1960-tallet hadde kravet om doktorgrad for fast ansettelse fungert som et uformelt krav, men sterk økning i antall studenter gjorde at det i 1985 bare var 38 prosent av vitenskapelig ansatte i Norge som hadde doktorgrad (NAVFs utredningsinstitutt, 1988). Et av Universitets- og høgskolekomiteens forslag i 1988 var å organisere doktorgradsprogram og å innføre et krav om doktorgrad for å kunne bli fast ansatt ved norske universiteter, noe som ble innført fra 1990 (NOU 1988: 28, s. 1988). 
Samme krav kom som en del av nasjonale standardiseringsprosesser også i Sverige og England (Bleiklie \& Høstaker, 2004, s. 230). Utviklingen av doktorgradsprogram var en relativt ny praksis ved universitetene, og en mulighet for høgskolene til å utvide sin stab med vitenskapelig ansatte $\mathrm{i}$ midlertidige stillinger som kvalifiserte til fremtidige faste stillinger. Ordningen med standardiserte doktorgradsprogram var med på å sprenge det binære utdanningssystemet innenfra og å legge til rette for overgangsordninger og dermed også for nye universiteter (Bleiklie 2003, s. 341).

Mjøs-utvalget var ifølge Helsvig (2011, s. 124) starten på Bolognaprosessen i Norge. Utvalget foreslo blant annet, i likhet med Norgesnettrådets leder Magnus Rindal, at et uavhengig organ skulle overta for Norgesnettrådet, slik at faglige vurderinger ble løftet ut av departementet og dermed avpolitisert. Det ble presisert at akkreditering var en nødvendig, men ikke tilstrekkelig grunn til å generere støtte til et utdanningstilbud; tildelinger - og nye universiteter - skulle fortsatt godkjennes av politikerne. Forslaget kom som et resultat av at Lilletun overprøvde Norgesnettrådets avslag på søknaden fra Høgskolen i Bodø om forskerutdanning i bedriftsøkonomi (Haukland 2015, s. 147 ff.). Høgskolerådet reagerte også på at statsråden tok saken i egne hender, og enigheten på tvers av sektorene bidro til at Høgskolerådet og Universitetsrådet slo seg sammen til Universitets- og høgskolerådet (Haukland 2015, s. 151). Et uavhengig akkrediteringsinstitutt var tenkt både som bro og grensekontroll mellom sektorene.

Stortingsmelding 27 (2000-2001), som la grunnlaget for Kvalitetsreformen, inneholdt forslag om at «opprykksordningen til professorstilling avvikles» (Utdannings- og forskningsdepartementet 2001, s. 64). Opprykksordningen bidro til å bryte ned det binære utdanningssystemet, den stimulerte til forskerutdanninger ved høgskolene og utgjorde en økonomisk utfordring med hensyn til høyere lønnsutgifter. Opprykksordningen ble stående sammen med forslaget om et uavhengig akkrediteringsorgan. Også her hadde Stortinget en sentral rolle i utviklingen av feltet (Kyvik 2009, s. 63).

\section{Det geografiske paradigmet under press}

Det geografiske paradigmet har vært et seiglivet anker for norsk høyere utdannings infrastruktur all den tid studiesteder var etablert over hele landet. 
Flere initiativ fra lokalt nivå ledet fram til at det geografiske paradigmet vaklet, der universitetsprosessene i Agder, Rogaland og Nordland, i tillegg til andre fylker som ikke kom i mål med sine prosesser, til dels uintendert satte dette under sterkt press. De regionale aktørene, både høgskolene, kommunene, fylkeskommunene, politikere knyttet til regionen og andre institusjoner, kjempet for muligheten til å entre den tradisjonelle universitetssektoren. Ledelsen ved Høgskolen i Bodø argumenterte med at fylket trengte å heve utdanningsnivået, og at universitetstittelen ville gjøre høyere utdanning mer attraktivt slik at flere studenter meldte seg, noe som ville skape vekst også for næringslivet. At studentene var forbrukere, sto her sentralt. Dessuten ville universitetstittelen bidra til at forskningsmiljøene kunne gjøre en enda større innsats for regionen, de ville kunne stå mer fritt til å etablere studietilbud det var behov for. Det var dessuten altfor langt for nordlandsungdommen til Tromsø og Trondheim til at universitetene her var tilfredsstillende alternativer. Argumentene relaterte til det geografiske paradigmet på ulike måter.

Men aktørene som var involvert i universitetsprosessen i Bodø, så for seg at universitetsstatusen skulle bringe med seg noe som i realiteten var i ferd med å gå tapt i universitetssektoren: institusjonell autonomi på linje med tradisjonelle universiteter med utgangspunkt i kollegiet (Haukland, 2019).

Flere grep ble tatt fra sentralt hold som på mer eller mindre intenderte måter førte til at paradigmet raknet.

For det første innebar presset fra høgskolesektoren om å etablere overgangsordninger for forskerutdanninger og endring av institusjonskategori fra høgskole til universitet at egalitære verdier ble overført til spørsmål knyttet til faglig kvalitet. Argumentet var grunnleggende at om kvaliteten var god nok, var det ingen grunn til at en høgskole ikke skulle kunne bli akkreditert som universitet. Dermed bleknet det geografiske paradigmet, som i utgangspunktet hadde vært argumentet for å etablere de regionale høgskolene.

For det andre bidro innføringen av enhetlig ledelse og tilsatt rektor, som ble gjennomført ved Høgskolen i Bodø i 2006 og ved Høgskolen i Nesna i 2011, til at ekstern styreleder uten tilknytning til regionen fikk «hendene på rattet». For de to institusjonene førte dette til to ulike prosesser. For Høgskolen i Bodø ble ekstern styreleder Rindal, som hadde markert seg som en sterk tilhenger av at faglighet skulle trumfe politikk, en sterk bidragsyter 
til universitetsprosessen. ${ }^{17}$ For Høgskolen i Nesna sto som nevnt ekstern styreleder sentralt i prosessen rundt fusjonen med det nye Universitetet i Nordland. Begge prosessene bidro til å sprenge det geografiske paradigmet.

Høgskolereformen kan ses på som gjennomføringen av det geografiske paradigmet i Norge; utdanningsregionene Ottosen-komiteen tok til orde for, var nå realisert. Reformen samlet all høgskoleutdanning fylkesvis, med unntak av Nordland, Møre og Romsdal og Oppland. Her ble høgskolesektoren brukt som et distriktspolitisk virkemiddel for å samle regionene, noe som var en umulighet i Nordland på grunn av store avstander og utfordringer knyttet til infrastruktur. I tillegg var nordlandsidentiteten, som ifølge Harald Rinde (2015, s. 359) har vært svak, primært knyttet til fylkeshovedstaden Bodø.

I motsetning til dette kan strukturreformen ses på som gjennomføringen av et nytt paradigme som sprengte seg vei med god hjelp fra universitetsprosessene i Rogaland, Agder og fra årtusenskiftet også Nordland. Det akademiske paradigmet var et resultat av behovet for effektivisering og målstyring av det høyere utdanningsfeltet for å sikre at norske høgskoler og universiteter holdt tritt med lignende høyere utdanningsinstitusjoner på det nye europeiske utdanningsmarkedet. Som distriktspolitisk virkemiddel ble høgskolesektoren nærmest avviklet for å fremme det akademiske paradigmet. De to paradigmene er presentert skjematisk i figur 2:

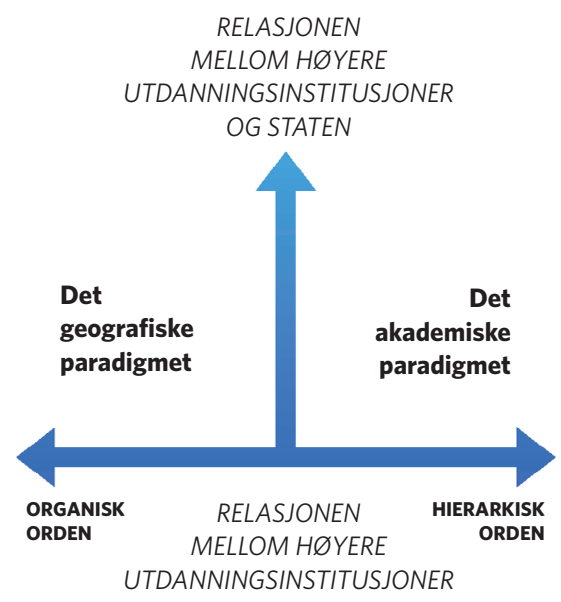

Figur 2. Det geografiske og det akademiske paradigmet. ${ }^{18}$

17 Haukland, 2015, s. 155. Rindal var som nevnt tidligere leder av Norgesnettrådet og insisterte på at
rådet skulle være basert på faglighet og ikke politisk forankret.
18 Haukland, 2019. Basert på Bleiklie (2003) og Kyvik (2009). 
Det akademiske paradigmets gjennombrudd fikk to helt forskjellige konsekvenser for Høgskolen i Nesna og Høgskolen i Bodø, slik tabell 2 viser. Det er likevel et reelt scenario at også Nord universitet blir fusjonert med Universitetet i Tromsø, slik Stjernø-utvalget tok til ordet for i 2008 og statsråd Røed Isaksen i 2014 (NOU 2008: 3, s. 64; Hansen, 2014). Nord universitet vil i så fall bli en campus i periferien både i landsdelen og $\mathrm{i}$ landet for øvrig.

\begin{tabular}{|l|l|l|}
\hline Kravet om faglighet & Høgskolen i Bodø & Høgskolen i Nesna \\
\hline Felles lov (1995) ${ }^{19}$ & Overgangsordning mulig & Svekket status \\
\hline Felles råd (2000) & Forsterket sentrum & Forsterket periferi \\
\hline $\begin{array}{l}\text { Uavhengig } \\
\text { akkrediteringsinstitutt (2003) }\end{array}$ & $\begin{array}{l}\text { Avgjørende for } \\
\text { universitetsstatus (2011) }\end{array}$ & Avgjørende for fusjon (2016) \\
\hline $\begin{array}{l}\text { Forskrift for universiteter og } \\
\text { høgskoler (2006) }\end{array}$ & $\begin{array}{l}\text { Gitte kriterier for } \\
\text { universitetsstatus basert på } \\
\text { kvantitative mål }\end{array}$ & $\begin{array}{l}\text { Lav rangering som } \\
\text { breddehøgskole }\end{array}$ \\
\hline Tellekantsystemet (2006) & $\begin{array}{l}\text { Synliggjøring av akademisk } \\
\text { kompetanse }\end{array}$ & $\begin{array}{l}\text { Tåkelegging av } \\
\text { samfunnsnytte }\end{array}$ \\
\hline Stjernø-utvalget (2008) & $\begin{array}{l}\text { Fusjon med Universitetet i } \\
\text { Tromsø til landsdelsuniversitet } \\
\text { anbefales } \\
\text { Enhetlig ledelse løftes fram, } \\
\text { er allerede på plass siden } \\
\text { 2006. Ekstern styreleder aktiv } \\
\text { i universitetsprosessen }\end{array}$ & $\begin{array}{l}\text { Rekrutteringsestimat basert } \\
\text { istedenfor i nedslagsfelt/ } \\
\text { cirkumferens } \\
\text { Enhetlig ledelse innføres i } \\
\text { 2011 på grunnlag av utvalgets } \\
\text { anbefaling. Ekstern styreleder } \\
\text { aktiv i fusjonsprosessen }\end{array}$ \\
\hline
\end{tabular}

Tabell 2. Det akademiske paradigmets gjennombrudd.

\section{Konklusjon}

Endringsdynamikkene på feltet som her er beskrevet, var ikke alltid intendert. De var snarere et resultat av samspillet mellom de enkelte nivåene og av implementeringen av nasjonale reformer på lokalt nivå, enn et resultat av en politisk toppstyrt utvikling. Prosesser knyttet til det regionale nivået som for eksempel Nordland bidrar til å kaste lys over disse endringsdynamikkene.

19 Universitetsloven, 1995; Haukland (2018, s. 84 ff.). Dette var første felles lov for høgskoler og universiteter, noe som innebar en integrering, men samtidig ble skillet mellom sektorene klarere gjennom at det nå måtte en lovendring til for å endre institusjonskategori fra høgskole til universitet. Dette fordi alle høyere utdanningsinstitusjoner var navngitt i loven. 
Scott (2014, s. 229) har påpekt at den sterkeste potensielle konflikten på et felt ligger mellom dem som besitter mest av den viktigste ressursen, og deres utfordrere. Det geografiske paradigmet ble gradvis svekket etter hvert som de sterkeste høgskolemiljøene søkte å bli mer lik et universitet. I universitetssektoren var det institusjonelle logikker knyttet til akademisk kultur som rådde, og høgskoler som skulle bli universitet, måtte innfri strenge krav til forskning og forskerutdanninger. At de ikke ble målt på hvilken rolle de spilte i sin region, ble knapt problematisert all den tid universitetsprosessene genererte stor regional støtte og universitetsstatus i seg selv ble sett på som en styrking av regionen. For landets minste høgskoler, som Høgskolen i Nesna, ble dette fatalt. Det nyttet ikke at høgskolen var den eneste som utdannet lærere til fådelt skole, når parametrene institusjonen ble målt på, var i tråd med et akademisk paradigme. For høgskoler som ikke aspirerte til universitetsstatus, innebar utviklingen til slutt tap av autonomi.

Ved høgskolereformen var det i stor grad en organisk orden som gjorde seg gjeldende i Nordland, som beholdt tre høgskoler, mens strukturreformen var et uttrykk for en sterkere hierarkisk orden på feltet. Den institusjonelle integreringen i forbindelse med strukturreformen gir et bilde av et utdanningssystem som går fra en organisk mot en hierarkisk orden ved hjelp av fusjoner. De studiestedene i Nordland og tidligere Nord-Trøndelag som tilhørte Nord universitet, var imidlertid intakt. En organisk orden var dermed fortsatt i spill, og er når dette skrives, utfordret blant annet av at Nord universitets styre i juni 2019 vedtok at studiested Nesna skal legges ned.

De to største omleggingene av infrastrukturen i norsk høyere utdanning etter etableringen av distriktshøgskolene skjedde i forbindelse med høgskolereformen i 1994 og strukturreformen i 2016. Den første omleggingen plasserte infrastrukturen etter fylkesregioner og var på mange måter sluttføringen av Ottosen-komiteens opprinnelige plan om å samle all høgskoleutdanning i hvert fylke under samme ledelse.

Den andre omleggingen, som også førte til en sterk reduksjon i antall høgskoler, tok andre hensyn. Her var det geografiske paradigmet nærmest fraværende. Fylkesgrensene var ikke lenger avgjørende for hvilke fusjoner som fant sted. Kriteriene var i stor grad knyttet til en hierarkisk orden der akademisk status var førende for fusjonsprosessene, som var 
løftet ut av politiske fora og inn i styrerommene ved de involverte høyere utdanningsinstitusjonene. Resultatet ble blant annet at Høgskolen i Nesna ble fusjonert inn sammen med Høgskolen i Nord-Trøndelag og Universitetet i Nordland til Nord universitet, som nå skulle ivareta høyere utdanning i to fylker. Høgskolen i Narvik, som lå lengst nord i Nordland, fusjonerte med Universitetet i Tromsø. Det geografiske paradigmet var ikke lenger førende for høyere utdannings infrastruktur, noe som kan tyde på at den organiske orden ikke lenger spiller en avgjørende rolle for utdanningstilbudet i regionene. Strukturreformen var på mange måter gjennomføringen av Kleppe-komiteens opprinnelige forslag fra 1965, da høyere utdanning kun ble gitt ved landets universiteter, om å sluse veksten i antall studenter inn i universitetssektoren.

Utviklingen kan ses som et resultat av at universitetet som symbol og hegemonisk kulturbærer trumfer andre institusjonelle logikker på det høyere utdanningsfeltet.

\section{Referanser}

Bakken, A.-L. \& Hveding, E. (1991). Styringsordning for regionale høgskoler. En utredning for Utdannings- og forskningsdepartementet. Oslo: Kirke-, utdannings- og forskningsdepartementet.

Berg kartografi / Nord universitet. (2018). Berg, H., Undersøkelse basert på elevlister ved lærerutdanningen på Nesna 1918-2018. Bodø: Nord universitet.

Bleiklie, I, Høstaker, R. \& Vabø, A. (2000). Policy and practice in higher education. Higher Education Policy Series, 49.

Bleiklie, I. (2003). Hierarchy and specialisation: On the institutional integration of higher education systems. European Journal of Education, 38(4), 341-355. https:// doi.org/10.1111/j.0141-8211.2003.00153.X

Bleiklie, I. \& Høstaker, R. (2004). Modernizing research training-education and science policy between profession, discipline and academic institution. Higher Education Policy, 17(2), 221-236.

Bleiklie, I. (2007). The social foundations of the evaluative state and the universities as stakeholder organisations. I J. Enders \& F. van Vught (Red.), Towards a cartography of higher education policy change (s. 97-104). Enchede, Nederland: Center for Higher Education Policy Studies.

Clark, B. (1983). The contradictions of change in academic systems. Higher Education, 12, 101-116. 
DiMaggio, P. J. \& Powell, W. W. (1983). The iron cage revisited: Institutional isomorphism and collective rationality in organizational fields. American Sociological Review, 48(2), 147-160.

Enebakk, V. (2009). UNESCO og vitenskapshistoriens relevans. I J. P. Collett, J. E. Myhre \& J. Skeie, Kunnskapens betingelser. Festskrift til Edgeir Benum (s. 124-145). Oslo: Vidarforlaget.

Forskr om akkreditering etter universitetsloven. (2006). Forskrift om akkreditering, evaluering og godkjenning etter lov om universiteter og høyskoler per 25.01.2006. På mail fra Nokut til forfatter. Ikke publisert på Lovdata.

Fulsås, N. (1993). Universitetet $i$ Tromsø 25 år. Tromsø: Universitetet i Tromsø.

Fulsås, N. (2000). Frå binært til hierarkisk system i høgare utdanning?. Historisk tidsskrift, 79(3), 385-396.

Fygle, S. (1995). Fem høgskoler blir til tre høgskolesentra. Høgskolevirksomhetens historie i Nordland 1970-1994 (upublisert rapport). Bodø: Nordlandsforskning.

Gornitzka, Å. (1999). Governmental policies and organizational change in higher education. Higher Education, 38(1), 5-31.

Hansen, Fritz. (23.08.2014). Kunnskapsminister Torbjørn Røe Isaksen vil ikke vente på Stortinget, men legge ned høyskolene i nord så raskt som mulig. Fremover [Narvik]. Hentet fra fremover.no

Haukland, L. H. (2015). Nye høyder. Framveksten av Universitetet $i$ Nordland. Stamsund: Orkana Akademisk.

Haukland, L. (2017). The Bologna Process: The democracy-bureaucracy Dilemma. Journal of Further and Higher Education, 41(3), 261-272. https://doi. org/10.1080/0309877X.2015.1070403

Haukland, L. H. (2018). Universitetet $i$ Nordland. Spenninger og samspill i en høgskolesektor. (Doktoravhandling, Fakultet for samfunnsvitenskap, Nord universitet, Bodø). Hentet fra https://www.dropbox.com/s/jsedxnmn54c8ego/ Phd\%2onr.\%2033-2018\%20FSV\%2oLinda\%2oHelen\%2oHaukland.pdf?dl=o.

Haukland, L. H. (2018b). Loererutdanningen på Nesna 1918-2018. Trondheim: Museumsforlaget.

Haukland, L. H. (2019). The Bologna process and HEIs institutional autonomy in Norway. Upublisert, ifm. 21st. ATINER International Conference on Education, 20.-23. mai 2019. Athen: ATINER.

Helsvig, K. (2011). Universitetet i Oslo 1975-2011. Mot en ny samfunnskontrakt?. I J. P. Collett (Red.), Universitetet i Oslo 1811-2011 (Bd. 6). Oslo: Unipub.

Johnsen, B. W. (1999). Fra universitetsvisjon til høyskoleintegrasjon. Kristiansand: Høyskoleforlaget.

Kogan, M. \& Hanney, S. (2000). Reforming higher education. London og Philadelphia: Jessica Kingsley. 
Kristvik, E. (1928). Den nordnorske læraren. Vilkår for og krav til skolearbeidet i Nord-Norge. I O. Krogness, K. Nielsen \& K. Nissen, Festskrift til rektor J. Qvigstad (s. 101-112). Tromsø: Tromsø museum.

Kyvik, S. (2009). Higher education dynamics. The dynamics of change in higher education. Expansion and contraction in an organisational field. New York: Springer.

Meyer, J. W., Ramirez, F. O., Frank, D. F. \& Schofer, E. (2008). Higher Education as Institution. I P. J. Gumport (Red.), Sociology of education: Contributions and their contexts (s. 187-221). Baltimore: Johns Hopkins University Press.

Monsen, I. (1993). Utdanningssektoren i vekst og forandring 1950-1991. I Sosialt utsyn (Rapport nr. 6/1993, s. 118-143). Oslo: Statistisk sentralbyrå.

Musselin, C. (2000). Do we compare societies when we compare national university systems?. I M. Maurice \& A. Sorge (Red.), Embedding organizations: Societal analysis of actors, organizations and socio-economical context (s. 295-309).

Amsterdam, Nederland: John Benjamins Publishing Company.

NAVFs utredningsinstitutt. (1988). Doktorgrader i Norge: En kvantitativ oversikt. Utredninger om forskning og høyere utdanning. Oslo: Norges allmennvitenskapelige forskningsråd.

Neave, G. (1996). Higher education policy as an exercise in contemporary history. Higher Education, 32(4), 403-415.

Nord universitet (1918-2018). Diverse korrespondanse. Arkiv Nesna (uordnet).

Nord universitet (1971-1985). Nordland distriktshøgskole. Arkiv Bodø (uordnet).

Nord universitet (1971-1993). Nesna loererhøgskole. Arkiv Nesna (uordnet).

Nord universitet (1977). Boks "Korrespondanse 1977». Arkiv Nesna (uordnet).

Nord universitet (1986-1993). Høgskolesenteret i Nordland. Arkiv Bodø (uordnet).

Nord universitet (1994-2010). Høgskolen i Bodø [Ephorte]. Arkiv Bodø (uordnet).

Nord universitet (1994-2015). Høgskolen i Nesna. Arkiv Nesna (uordnet).

Nord universitet (2011-2015). Universitetet $i$ Nordland [Ephorte]. Arkiv Bodø (uordnet).

NOU 1988: 28. (1988). Med viten og vilje. Oslo: Kultur- og vitenskapsdepartementet.

NOU 2008: 3. (2008). Sett under ett - ny struktur i høyere utdanning. Oslo: Kunnskapsdepartementet.

Rinde, H. (2015). Det moderne fylket. Etter 1900. I A. R. Nielssen (Red.), Nordlands historie (bd. 3). Bergen: Fagbokforlaget.

Scott, W. R. (2014). Institutions and organizations. Ideas, interests, and identities. Thousand Oaks, CA: Sage.

Slagstad, R. (1998). De nasjonale strateger. Oslo: Pax forlag.

Solhjell, D. (1977). Universitet, by og landsdel: Om Universitetet i Tromsø og utbyggingen av Nord-Norge. Tromsø: Universitetsforlaget. 
Stensaker, B. (2006). Governmental policy, organisational ideals and institutional adaptation in Norwegian higher education. Studies of Higher Education, 31(1), 43-56.

Trow, M. (2010). Twentieth-century higher education: Elite to mass to universal. Baltimore: Johns Hopkins University Press.

Thornton, P. H. \& Ocasio, W. (2017). Institutional logics. I R. Greenwood, C. Oliver, K. Salin-Andersson \& R. Suddaby (Red.), Handbook of organizational institutionalism (s. 99-129). London, UK: Sage.

Universitetsloven. (1995). Lov om universitet og høgskoler (LOV-1995-05-12-22). Hentet fra https://lovdata.no/pro/\#document/NLO/lov/1995-05-12-22

Utdannings- og forskningsdepartementet (2001). Gjør din plikt - Krev din rett. Kvalitetsreform av høyere utdanning (Meld. St. 27 (2000-2001)). Oslo: Utdannings- og forskningsdepartementet.

Witte, J., van der Wende, M. \& Huisman, J. (2008). Blurring boundaries: How the Bologna process changes the relationship between university and non-university higher education in Germany, the Netherlands and France. Studies in Higher Education, 33(3), 2008, 217-231.

Yttri, G. (2008). Frå skuletun til campus. Soga om Høgskulen i Sogn og Fjordane. Leikanger: Skald.

Yttri, G. (2016). Gjennombrot og kjenneteikn. Liner i soga om høgare utdanning i Sogn og Fjordane. (Doktoravhandling). Oslo: Universitetet i Oslo. 


\title{
Reorganisering av UH-sektoren - nasjonsbygging med regionsmak
}

\author{
Jon P. Knudsen ${ }^{1}$ \\ Universitetet i Agder
}

\begin{abstract}
In this chapter, the institutional development of higher education and research in Norway is analysed as a process that has been intimately intertwined with the strong geographical dimension of the country's nation-building process. This aspect of the sector's development has been important under different phases of its political history. To be legitimate, national political decisions have always had to consider and mediate between conflicting regional interests. Following Mark Bevir's (2011) distinction between different stages of nation building, I especially point at how decision makers under the present phase of a neoliberal and networking state seem to act as if the geographical rationales underpinning the national project can be ignored. The sector in question offers an illustrative case, as higher educational institutions bear a stronger affinity to their regional embeddedness than often acknowledged.
\end{abstract}

Keywords: higher education, nation building, regionalization, Norway

\section{Innledning}

De siste årene har vi vært vitne til en heftig debatt her til lands om hvordan den regionale strukturen innenfor høyere utdanning og forskning best bør organiseres. Flere av innleggene i denne boka har beskrevet denne utviklingen og pekt på de lange linjene bak fremveksten av en regionalt distribuert institusjonsflora innenfor sektoren. Jeg skal ikke gå i detalj om historien, men heller forsøke å se hvordan noen lange linjer i

1 Peter Arbo og Torunn Lauvdal takkes for verdifulle kommentarer på et førsteutkast til denne artikkelen.

Sitering av dette kapitlet: Knudsen, J. P. (2019). Reorganisering av UH-sektoren - nasjonsbygging med regionsmak. I J. P. Knudsen \& T. Lauvdal (Red.), Geografi, kunnskap, vitenskap. Den regionale UH-sektorens framvekst og betydning (s. 241-264). Oslo: Cappelen Damm Akademisk. https://doi. org/10.23865/noasp.73.ch10.

Lisens: CC BY 4.0 
det historiske forløpet treffer det jeg vil kalle en nyere tendens til oppløsing av den territorielle forståelsen. Jeg vil slik antyde en forklaring på de siste årenes politiske beslutninger (eller ikke-beslutninger) om sektorens geografiske struktur.

Peter Arbo (2019) avslutter sitt kapittel med følgende punchline: «Mens universitetene eksploderer og sprenger grenser, ser det ut til at mange av regionene imploderer og blir stadig mer fragmenterte.» Arbos poeng om at universitetene bli grenseløse, samtidig som regionene fragmenteres og imploderer, er en variant av et grunntema innenfor geografien: Hvordan skal vi forstå den tid-/rom-kompresjonen som preger vår tid (Harvey, 1989), og som blant annet har den paradoksale effekt at mens regionene fra ett perspektiv blir viktigere både i økonomisk og politisk forstand (Porter, 1990; Foray, 2015), er dette en betydning de først kan realisere ved å samhandle inn i en overregional og global orden (Fitjar \& Rodriguez-Pose, 2013; Reve \& Sasson, 2012). ${ }^{2}$ Gjennom slik samhandling trues regionen dermed også av sin egen oppløsing. Michael Porter (200o) har for eksempel i en oppfølger til sin bok om regionenes innfasing i den globale økonomien (Porter, 1990) eksplisitt hevdet at han tror alle regionale særdrag over tid blir nivellert ut i globale homogeniseringsprosesser.

Bortsett fra at et slikt resonnement grovt undervurderer moderniseringens parallelt heterogeniserende effekter, er det interessant å notere seg hvordan en $\mathrm{i}$ et land som tradisjonelt har måttet veie regionale interesser mot hverandre så sterkt som tilfellet har vært i Norge (Hansen, 1972; Knudsen, 2018; Rokkan, 1967), ved det 21. århundres inngang plutselig kan handle som om geografiens historiske føringer er opphevet. På samme måte som det i sin tid ble politisk opportunt for kirkeministre å opptre teologisk døvt og blindt, er det i dag, for enkelte departementer med ansvar for regionalt viktige sektorer, mulig å handle som om Norge ikke lenger hadde geografi. Jeg har i en annen sammenheng argumentert for hvordan selv det departementet som har fagansvar for regionalpolitikk i Norge, særlig etter regjeringsskiftet i 2013 bevisst har ført en politikk som har nedtonet både den smalere distriktspolitikkens

2 Jeg unnlater, for ikke å komplisere ytterligere, nasjonalstatens tilbakekomst i dette bildet, slik vi i dag ser det på den politiske og økonomiske arenaen i Europa og Nord-Amerika. 
og den overordnede regionalpolitikkens betydning som saksområder (Knudsen, 2018). I et lengre perspektiv er det godt dokumentert at denne politiske dreiningen ble tydelig som tendens allerede fra begynnelsen fra 1990-tallet (Teigen, 2012).

Denne nyorienteringen har etter 2013 skutt fart og tatt ulike former, som eksplisitt fjerning av 'regional-' i Kommunaldepartementets navn, som rask nedtrapping av bevilgninger til regional- og distriktspolitiske formål, og sterk endring i a mbisjon og styring overfor underliggende organer (Innovasjon Norge, SIVA, Distriktssenteret) og overfor forskningsprogrammer med regionalpolitisk innretning (Knudsen, 2018). Den mest interessante artikuleringen av den nye regionale indifferensen for denne artikkelens formål, er imidlertid den som nettopp vises ved at neglisjeringen gjøres eksplisitt. På samme måte som teologien i eksemplet ovenfor ble definert som et spørsmål for teologer, trossamfunn og lekfolk, og ikke som noe staten burde befatte seg med, er spørsmålet om regionalpolitikk i ferd med å undergå den samme utvikling. De to store reformene vi har hatt som direkte har berørt regional struktur under Solberg I-regjeringen, kommunereformen og regionreformen, har begge hatt frivillighet som prinsipp og nabopraten som verktøy. Det har betydd at staten har nøyd seg med å stille noen helt overordnede krav til effektivitet og skala og så overlatt resten til aktørene.

Nå er ikke denne fremgangsmåten ny. Stoltenberg I-regjeringen gjorde det samme da den i 2002 overførte sykehusene fra fylkeskommunalt eierskap til egne foretak, som dermed også skulle ha ansvar for sykehussektorens geografiske struktur og regionale tilbud. Den regionale dimensjonen søkes på denne måten fjernet fra de riks- og fylkespolitiske kartene for i stedet å bli overført til aktører som forventes å løse konflikter knyttet til disse dimensjonen på rent formal-pragmatisk grunnlag. Det er videre verdt å merke seg at dette ikke skjer med saksområder der den geografiske dimensjonen er av mindre betydning, men med områder der denne dimensjonen står helt sentralt. På samme vis som kirkestyret har beveget seg fra sin fremskutte plass i Grunnlovens $\$ 2$ til full avpolitisering i en lang historisk prosess, går den regionale dimensjon fra å være en av hoveddimensjonene i det norske nasjonsbyggingsprosjektet (Rokkan, 1967) til å bli trivialisert i nasjonens senmoderne fase. 
Mer prinsipielt betyr en slik handlemåte at skiftende regjeringer med Stortingets tilslutning abdiserer som regionalpolitisk myndighet, og at det da heller ikke finnes noen plass for samordning av det vi kaller stor regionalpolitikk. Med stor regionalpolitikk menes den politikk som legger geografiske føringer på sektorpolitikkene slik disse utformes av de ulike fagdepartementene. Regionalpolitikken, i den grad den kan bestemmes ideologisk, ses fra et rent regionalliberalistisk ståsted (Johnstad mfl., 2003). Fra et slikt synspunkt vil regioner og regionale aktører kunne opptre tjenlig fra et sentralt, statlig perspektiv i den grad de bidrar til å realisere eventuelle andre mål. Slike mål vil da ofte bære mer preg av overordnede ønsker om for eksempel nasjonal økonomisk vekst, økt innovasjonsevne, forsterket kunnskapsoppbygging o.l. enn av forhold knyttet til fordelingspolitikk og regionalt forankret nasjonsbygging. I den grad det stadig finnes en overordnet regionalpolitisk ambisjon, kan vi med Bukve (2005) si at den tar form av det han kaller konkurranseregionalisme, det vil si at regioner måles for sin evne til å skåre på nasjonale mål knyttet til ulike (økonomiske) parametere. En slik nasjonalt eller internasjonalt innrammet konkurranseregionalisme kan brukes til å utvikle verktøy for å overvåke, sammenligne og stimulere regional utvikling overordnet og sektorvis, slik det for eksempel skjer i OECD- eller EU-sammenheng, ikke minst på utdannings- og forskningsfeltet (OECD 2018, ESPON 2014).

\section{Nærmere om problemstilling}

Utviklingen, slikjeg skisserer den i dette kapitlet, topper seg i den prosessen som har kjennetegnet de siste års reorganisering av UH-sektoren, og mer spesifikt i det resultatet denne prosessen har fått for to regioner, Nordvestlandet og Innlandet. Mens andre regioner har fått egne universiteter med hovedsete og hovedcampus i egen region definert etter Regionreformens geografi slik den vil nedfelles fra 2020 av (Ekspertutvalget, 2018, s. 41), ser dette ikke ut til å bli tilfellet for Nordvestlandet og Innlandet. Her vil status så langt være at NTNU har campuser i Ålesund og på Gjøvik. De øvrige høgskolene i Møre og Romsdal vil inntil videre fortsette som egne høgskoler, mens Høgskolen i Innlandet sendte sin søknad om universitetsstatus til NOKUT i desember 2018, så langt med uvisst utfall. 
Den foreløpige statusen vil da være at ni av de elleve nye fylkene vil ha egne universiteter, mens to vil inngå i en filialisert struktur under NTNU. Flere universiteter og høgskoler vil ha campuser i flere enn ett fylke. En kan gjøre seg mange betraktninger om dette. Ett poeng kan være at de to enhetene som søkte sammen med NTNU, Høgskolen i Gjøvik og Høgskolen i Ålesund, var de to som fra et NTNU-perspektiv fremsto som faglig mest interessante og dermed også mest attraktive som fusjonspartnere for et ambisiøst universitet. Parallelt til dette kan det hevdes at de samme to høgskolene var de som fra et utsiktspunkt i egen region hadde den største faglige kapital å kaste inn i kampen om akademisk statusoppgradering, og at det derfor må betegnes som et tap for de to regionene dette gjaldt, at disse to høgskolene ikke kunne bli med og trekke opp universitetsløpet på vegne av sine egne regioner. Til dette vil da noen hevde at det å bli en del av NTNU bringer så store gevinster til regionen at den skaden som er forvoldt ved å bryte bindingen til de andre høgskolene i egen region, oppveies. Om det siste er gyldig eller ikke, skal jeg her la ligge, bortsett fra å påpeke at et slikt argument umiddelbart virker mer som et argument å ty til enn som ett å tro på. Med de korte tidsspenn vi her snakker om, er dette uansett et lite forskbart spørsmål. Vi skal også ha in mente at med den hastigheten UH-prosessene går i, kan det godt være at dette institusjonslandskapet vil endre seg så mye i løpet av noen år, at resultatet av disse regionale prosessene vil se annerledes ut enn det gjør i skrivende stund. Det er i så fall et utfall som ikke er brakt fram av sentral politisk omtanke, men av underordnede aktørers egne spill.

Spørsmålet vi i stedet skal stille oss, er hva som forklarer at regjering og storting har sluppet det geografiske grepet om sektoren. Vi kan godt starte med å konstatere at en tidstypisk regionalliberalisme har grepet de sentrale aktørene. Men for å få bedre tak i hvordan denne vendingen henger sammen med tidligere forståelse av UH-sektorens institusjonelle betydning, kan det være på sin plass med en fortolkning.

Den britiske statsviteren Mark Bevir (2011) deler den vestlige verdens nyere institusjonelle utvikling inn i tre faser. Den første fasen kaller kan nasjonsbyggingsfasen, den neste forstår han som en fase for velferdsstatsutbygging, mens den siste er fasen for den neoliberale og nettverkende stat. Disse tre fasene kan vi se på som historiske epoker, men vi kan også 
forstå dem som aspekter ved et lands institusjonelle utvikling, der ulike aspekter vil være særlig tydelige på ulike steder og til ulike tider.

\section{Nasjonsbygging}

For Norges vedkommende er det vanlig å identifisere starten til nasjonsbyggingsfasen innenfor UH-sektoren, slik Arbo (2019) og Aamot og Lyby (2019) gjør det i sine artikler i denne boka, til vedtaket om opprettelsen av et eget universitet i Christiania i 1811. Vi bør imidlertid nevne at det allerede i 1757 ble opprettet et eget bergseminar på Kongsberg, som regnes som en av de første høyere tekniske læresteder i verden. Det kan i den sammenheng skytes inn at vedtaket om opprettelse av eget norsk universitet i 1811, også først pekte på Kongsberg som egnet lokalisering. Slik gikk det ikke, og i stedet ble bergseminaret nedlagt i 1814 (Blom, 1957). De neste og langt senere skrittene i denne fasen kom med opprettelsen av en høyere landbruksutdanning på Ås og en høyere teknisk utdanning i Trondheim. Det kan slik argumenteres med at nasjonsbyggingen i Norge allerede fra starten av hadde et sterkt regionalt aspekt. Bygging av nasjonale institusjoner fordret nasjonale kompromisser og regionale konsesjoner (Rokkan, 1967; Wicken, 1997, 2004). I det perspektivet er det naturlig å se etableringen av NTH i Trondheim, NHH i Bergen og den påfølgende universitetsutbyggingen i begge byene som en bekreftelse på en tyngdepunktstrid som i Norge går helt tilbake til vikingetiden. Den langt senere opprettelsen av Universitetet i Tromsø kan leses på samme vis, som en institusjonell bekreftelse på at Nord-Norge er en fullverdig del av det nasjonale byggverket (Arbo, 2019), sammen med de i institusjonell sammenheng tyngre landsdelene, Østlandet, Vestlandet og Trøndelag.

Men historien har også noen forløpere til disse prosessene. Om vi holder oss til tiden etter reformasjonen skriver Gilje og Rasmussen (2002, s. 88ff.) om hvordan det rundt domkapitlene ved bispesetene tidlig utviklet seg lærdomsmiljøer med regionalt preg. De identifiserer allerede fra midten av 1500-tallet av en bergens- eller vestlandshumanisme og en oslohumanisme som to ulike dannelsestradisjoner ved skolene i de to byene. Der oslohumanistene falt inn i den internasjonal fold, skrev på latin og pleiet båndene til København, skrev bergenshumanistene gjerne 
på dansk-norsk og ytret seg spørrende om hopehavet med Danmark. Vi kan hos denne siste gruppen lærde tale om en gryende proto-nasjonalisme. Tilsvarende kan vi benevne den vitenskapelige oppvåkning i Trondheim rundt 1760 med etableringen av eget vitenskapsselskap som fremste institusjonelle uttrykk, som en regionalt forankret foreteelse med stor samtidig, og enda større senere, nasjonal betydning (Gilje \& Rasmussen, 2002, s. 375 ff.).

Men det var ikke bare i byene at det utviklet seg kulturer som forberedte senere institusjonsbygging på kunnskapsfeltet. På bygdene, ikke minst på Nordvestlandet, hadde mange bønder fra 170o-tallet av egne biblioteker der samtidens litteratur ble samlet og brakt ut til en lesende bygdeoffentlighet. Mange landsens prester hadde også boksamlinger. Mye av denne litteraturen var av religiøs art, men der fantes også innslag av allmennyttig litteratur og også et og annet bokverk fra samtidens internasjonale filosofiske og vitenskapelige diskusjoner (Fet, 1995). Lesekyndigheten var i rask vekst utover på 1700-tallet både i bygd og by. Det kan nevnes som en kuriositet at Adam Smiths grunnleggende verk Wealth of Nations ble oversatt til dansk allerede i 1779 som den første autoriserte oversettelse til noe annet språk. Oversettelsen, som selv i sin samtid må ha blitt oppfattet som tung lesning, ble besørget av norske interessenter i Christiania og trykt i København, men storparten av opplaget ble antakelig solgt og distribuert i Norge (Banke, 1955; Hanisch mfl., 1999, s. 37; Kurrild-Klitgaard, 1998).

Det bør være et poeng å argumentere for at de regionale kunnskapsmiljøene som vokste fram i den tidlige nasjonsbyggingsfasen, gjorde det $\mathrm{i}$ vekselvirkning med regionale behov og uttrykk. Vel var mye av begrunnelsen for et eget norsk universitet at det skulle utdannes et embetsverk til å administrere landet (Arbo, 2019; Aamot \& Lyby, 2019), men den brede fremveksten av lærerseminarer, folkehøgskoler, landbruksskoler og underoffisersskoler, som fra 1800-tallet av kan ses på som det senere høgskolesystemets forløpere, fungerte også som læresteder der regionale kulturuttrykk og sedvaner ble utformet og brutt mot ny kunnskap utenfra. Ikke minst fungerte folkehøgskolene og landbruksskolene, i likhet med i mange andre land, som innovasjonssteder både for landbruket selv og for de bygdene der denne næringen sto sterkt (Krokann, 1982 [1942]). Det 
er i norsk sammenheng påfallende hvordan landbruket tidlig både kom i inngrep med en boklig lærdomstradisjon og fikk sin egen høyere utdanningsinstitusjon, mens fiskeriene, som i et komparativt perspektiv har vært langt viktige for utviklingen av norsk økonomi, nærmest utviklet seg som ufaglært praksis. Det er først så sent som i 1972 at Norges fiskerihøgskole blir opprettet.

Disse regionale særdrag og praksiser som den tidlige institusjonsbyggingen innenfor kunnskapssektoren viser, kan forstås som dimensjoner vi ofte overser når vi kartlegger disse institusjonenes fremvekst. Det er både ufortjent og misvisende. Det kan gjerne argumenteres for at disse regionale trekkene ved den institusjonelle fremveksten i mange henseender var vesentlig for deres utforming og virkemåte. Vi kan tale om at det parallelt med regionalt ulike nedslag også oppstår paradigmatiske skiller i det institusjonelle landskapet. Noen eksempler illustrerer dette poenget.

Det mest opplagte eksempelet finnes på teologiens område. Den voksende kløften som ut gjennom 180o-tallet oppsto mellom en lekmannsorientert, lavkirkelig lutheranisme med tyngdepunkt på Sør-og Vestlandet og dens menighets- og statskirkeorienterte motstykker i resten av landet, førte i 1907 til dannelsen av et eget teologisk læresete, Menighetsfakultetet, i opposisjon til og konkurranse med Det teologiske fakultet ved Universitetet i Oslo (Oftestad, 1998). Fra før av (1843) hadde det sterke misjonsengasjementet i det sørvestlandske bibelbeltet ført til opprettelse av en egen misjonshøgskole i Stavanger. Innenfor dette feltet har det, parallelt med dagens reorganisering av den offentlige UH-sektoren, skjedd en samling av en rekke høgskoler med kristelig motkulturpreg innenfor flercampusorganisasjonene VID med tyngdepunkt i Stavanger og Sandnes og NLA med tyngdepunkt i Bergen og Kristiansand.

Spenningene på det pedagogiske feltet var knapt mindre. Parallelt med økt språkstrid og i nært samband med en tiltakende norskdomsbevegelse, vokste det fra begynnelsen av 1900-tallet av fram en pedagogikk som både fremmet nynorsken, og som så på det pedagogiske oppdraget med helt andre tilganger enn dem som fantes i den eksisterende tradisjonen rundt byskolene. Bakgrunnen for denne mobiliseringen er nettopp den bokbaserte bygdeoffentligheten som er referert ovenfor. Den fremste ideologen i denne tradisjonen, Erling Kristvik, utformet fra mellomkrigstiden av 
et program som nettopp så nasjonen som en forstørret bygdeoffentlighet, tilført innsikt fra samtidens organisk orienterte samfunnsvitenskap, fremst representert ved Frédéric Le Play og Émile Durkheim (Slagstad, 1998). Rune Slagstad (1998, s. 99-108) løfter Kristvik fram som en av de store utdanningspolitiske strateger; og det er verdt å merke seg at Kristviks programmatiske virke nærte seg fra to kilder: en nasjonalt utviklet variant av det vi kan kalle en ruralt forankret vestlandshumanisme - her er ingenting bergensk - og en kontinental sosiologitradisjon.

Kristiviks fremste institusjonelle bastioner var Lærerskolen i Volda og Norges Lærerhøgskole i Trondheim. Mot denne pedagogiske tradisjonen sto Oslo-dominerte pedagogiske retninger som særlig etter siste krig tok opp ulike amerikansk-inspirerte, evidensbaserte perspektiver på pedagogikk som så ble videreutviklet og tilpasset norsk kontekst ved Universitetet i Oslo, og der særlig ved Pedagogiske forskningsinstitutt (Dale, 1999; Helsvig, 2005). Det gir mening å forstå disse paradigmatiske stridene som uttrykk for akademisk spissing rundt ulike regionale skolekulturer, skiller som den dag i dag speiles helt ned i regionale variasjoner i grunnskolens omdømme og resultater (Knudsen, 2016).

Et annet interessant eksempel er det skisma som oppsto innenfor norsk økonomiforskning da den senere vinneren av Nobels minnepris i økonomi, Ragnar Frisch, i mellomkrigstiden brakte sin utvikling av den økonometriske tradisjonen innenfor økonomifaget til Universitetet i Oslo, der den kom til å bli benevnt Oslo-skolen innenfor faget. Denne retningen ble raskt dominerende ved Sosialøkonomisk institutt, og kom også til å spille en helt avgjørende rolle som premissleverandør for den måten norsk økonomisk planlegging og politikk ble utformet på etter krigen (Sæther \& Eriksen, 2014). Økonomer med et mer historisk eller liberalistisk perspektiv på faget søkte seg derfor i økende grad til den nyopprettede (1936) Handelshøyskolen i Bergen (NHH), der de rent paradigmatisk kom til å danne et annet sentrum enn Frisch og Oslo-skolen.

Det siste eksemplet jeg vil trekke fram, er lokalsamfunnsforskningen ved Universitetet i Tromsø slik den kom til å utformes rundt Ottar Brox: I et institusjonelt perspektiv kan det diskuteres om etableringen av Universitetet i Tromsø best kan forstås innenfor Bevirs første (nasjonsbygging) eller andre fase (velferdsstatsutbygging), slik Fitjar og Alpaydin (2019) 
gjør i sin artikkel. Jeg velger å henføre denne etableringen til den første fasen, fordi den markerer et av hovedgrepene i arbeidet for å inkorporere Nord-Norge som en fullverdig del av den nasjonale infrastrukturen. Når det er sagt, kan det i seg selv også gis gode grunner for å argumentere for at velferdsstatsutbyggingen, slik den i mange land kom til å arte seg fra og med den siste del av mellomkrigstiden og i enda større grad etter krigen, i seg selv innebar en utstrekking og legitimering av nasjonsbyggingsprosjektet til nye grupper av folket (Hatland mfl., 2018).

Det særegne ved den samfunnsvitenskapelige utviklingen ved UiT er at den kom til å sentreres rundt en bearbeiding av egen regional kontekst i langt sterkere grad enn hva tilfellet var for de allerede etablerte universitetsmiljøene. I dette kan formingen av UiT som institusjon gjenkjennes i de senere høgskolenes og universitetenes tilnærming til sine regioners egenart og behov. Brox er utdannet sivilagronom og samfunnsviter og kom til å influeres sterkt av Norges kanskje fremste sosialantropolog, Fredrik Barth. Under Barths ledelse begynte han studiet av det som skulle bli hans hovedinteresse gjennom mange år: rurale aktørers og husholds lokale tilpasning til eksterne rammebetingelser og skiftende politiske regimer. Brox utviklet dette som en egen genre der den lokale tilpasningens sosiologi ble til et nedenfra-basert makroperspektiv på periferienes forutsetninger for å skape gode levekår og utvikling, i sterk praktisk og vitenskapelig polemikk med etterkrigstidens nasjonalt sentraliserte og økonomdrevne distriktspolitikk og samfunnsplanlegging. Som et alternativ til disse hegemoniske planregimene lanserte han et populistisk og generativt spor for en lokalsamfunnsbasert planlegging, der kooperative løsninger skulle være overbygning over individuelle og husholdsbaserte prioriteringer. Hans to vesentligste bidrag til argumentasjonen, Hva skjer i Nord-Norge? (Brox, 1966) og Nord-Norge - Fra allmenning til koloni (Brox, 1984), kom til å danne både en plattform for politisk handling ut over den regionale arenaen og et program for videre akademisk arbeid nasjonalt som internasjonalt. Brox etterfølger som professor ved UiT, Nils Aarsæther, kom sammen med kolleger så til å videreutvikle lokalsamfunnsstudier og lokalsamfunnsplanleggingen til en egen skoleretning med betydelig innflytelse innenfor nordisk planforskning. Festskriftet som ble utgitt til Brox' femtiårsdag, oppsummerer i 
så måte hans anliggender med den talende tittelen Folkemakt og regional utvikling (Aarsæther, Nilsen \& Reiersen, 1982). Dette eksempelet viser på samme måte som eksempelet Kristvik hvordan regionale praksiser danner tilfang til akademisk tenkning og institusjonsbygging med betydning langt ut over den egne konteksten.

Det regionale uttrykket i de regionalt forankrede akademiske miljøene er som oftest ikke tilfeldig, men bundet til regionspesifikke forhold og betingelser. Dette gjelder ikke minst for Frisch og Oslo-skolen. Den ble bundet til makten gjennom det som i ettertid er kalt jerntrianglet i norsk økonomisk politikk, hopehavet mellom Sosialøkonomisk institutt, Statistisk Sentralbyrå og Finansdepartementet. Instituttet utdannet kandidatene, SSB - oftest bare kalt Byrået - utførte analysene, mens departementet utformet politikken. Denne mikrogeografiske konstellasjonen av ren vitenskap, anvendt forskning og nasjonal politikkutøvelse fordret en hovedstads økologi for å kunne utvikle seg slik den gjorde, i alle fall med datidens fravær av elektroniske kommunikasjonsmuligheter.

\section{Velferdsstatsutbygging}

Bevirs fase 2, som omfatter den velferdsstatlige epoken i et lands utvikling, har en spesiell utforming i Norge. Selv om vi har en lengre tradisjon med sosiallovgivning, er det vanlig i historiske fremstillinger å datere utbyggingen av velferdsstaten til midten av 1930-tallet, med det historiske kompromiss mellom Arbeiderpartiet og Bondepartiet i 1935 og den samtidige inngåelsen av Hovedavtalen mellom partene i arbeidslivet. I den videre tenkningen om oppbygging av velferdsstaten hadde utdanning og forskning ingen fremtredende plass. Det viktigste plandokumentet som lå under for den nye given, En norsk treårsplan, forfattet av Ole Colbjørnsen og Axel Sømme, hadde andre prioriteringer (Røed, 2018). To begivenheter innenfor sektoren bør likevel nevnes, opprettelsen av Norges Handelshøyskole i Bergen i 1936 og fremveksten av Oslo-skolen som nytt paradigme for økonomisk forskning og politikkutviklingen. Etter krigen kom neglisjeringen av UH-sektoren til å fortsette. Til tross for at Norge opprettholdt et svært høyt investeringsnivå i europeisk sammenheng gjennom 50- og 6o-tallet, ble ikke UH-sektoren nevneverdig tilgodesett (Sæther, 2018, 
s. 18). I den grad vi hadde en forskningspolitikk i den første etterkrigstiden, var denne først og fremst industrielt argumentert og drevet innenfor et teknologioptimistisk moderniseringsrasjonale som vi delte med mange andre OECD-land (Fagerberg, Mowery \& Verspagen, 2009).

En ny start for sektoren kom derimot ved slutten av 1960-tallet. Denne utviklingen er fyldig beskrevet av Aamodt og Lyby (2019). Jeg skal derfor ikke repetere forløpet og utvikling, men heller peke på noen utviklingstrekk som faller inn i den generelle argumentasjonen. På utdanningssiden er det nødvendig å legge vekt på den voldsomme kvantitative ekspansjonen som skjedde innenfor sektoren. Denne var drevet av at velferdsstaten ble bygd ut, særlig i geografisk forstand, ved at kommunene ble tilført nye og større oppgaver etter kommunereformen først på 1960-tallet i kjølvannet av Schei-komiteens arbeid. Denne utviklingen ble senere fulgt opp ved at vi fikk nye folkevalgte fylkeskommuner fra 1976. Begge disse reformene økte behovet for akademisk arbeidskraft, men, særlig for kommunenes del, også det vi kom til å benevne arbeidskraft innenfor semiprofesjonene. Dette var arbeidskraft som de nye høgskolene som fulgte i kjølvannet av Ottosens-komiteens arbeid, skulle levere. Det er en tydelig geografisk sammenheng i det som fulgte. Velferdsstaten og de nye velferdsprofesjonene ekspanderte voldsomt, særlig lokalt og regionalt. Dette førte til en geografisk distribuert kompetansestruktur som ble ledsaget av en tilsvarende geografisk ekspansjon av utdanningssektoren. Aldri har vi hatt så mange høyere læresteder, beliggende på så mange steder som ved inngangen til 1980-tallet (Aamodt \& Lyby, 2019).

I norsk sammenheng kulminerte den geografiske utstrekningen av UH-sektoren samtidig med en sterk allmenn politisering av sentrumperiferi-dimensjonen. I hele den vestlige verden var 1970-tallet preget av systemkrise, politisk, industrielt og demografisk. For å ta det siste først. De store byene mistet, som i mellomkrigstiden, befolkning til periferien. Industrisysselsettingen flatet ut, og tjenestenæringene var ennå ikke i stand til å kompensere dette fullt ut. For første gang på lenge hadde utkantene demografisk momentum (IIleris, 1990). Politisk artet også 70-årenes systemmotstand seg annerledes i Norge enn ellers i Europa. EU-strid og bøndenes skattestreik skapte en voldsom mobilisering for distriktene, en utvikling et tradisjonelt teknokratisk og moderniseringstrent 
arbeiderparti hadde vanskelig for å forstå, men som mellompartiene kjente seg mer i slekt med. Aamot og Lyby (2019) viser da også i sin artikkel hvordan Korvalds sentrumsregjering i UH-politikken håndterte dette politiske stemningsskiftet bedre enn Arbeiderpartiet og Trygve Bratteli i hans to regjeringsperioder.

På forskningssiden kom utviklingen senere, og den er lettere å spore. NOU 1981:30, vanligvis kalt Thulin-utvalgets innstilling, etter lederen Lars Thulin, leverte ved overgangen mellom velferdsstatens geografiske ekspansjonsfase og inngangen til den etterfølgende nettverksstatens virke et budskap med ett ben i hver leir. Forskningsinnsatsen måtte økes, den skulle gjøres mer anvendt, og ikke minst den måtte distribueres. Det var, etter utvalgets mening også behov for å oversette teknologisk og annen relevant forskningsinnsikt mellom ulike kunnskapsaktører og geografiske nivåer, ikke minst for å få den geografiske periferien med for fullt. Dette budskapet ble plukket opp med begeistring av virkelystne entreprenører ved og rundt mange av landets nye regionale høgskoler. Regjeringen Willoch fulgte raskt opp budskapet i sin St.meld. 54 (1982-83). Resultatet var, som Aamodt og Lyby (2019) skriver, at Rogalandsforskning fikk selskap av en flora nye regionale forskningsstiftelser. En sektor var født.

\section{Den neoliberal og nettverkende stat}

På samme måte som det ikke er lett å trekke et entydig skille i tid mellom nasjonalstats- og velferdsstatsutvikling, er det heller ikke lett å tidfeste overgangen mellom velferdsstaten og den neoliberale og nettverkende stat. Én ting er at utviklingen kan være ulik fra land til, en annen ting er at denne overgangen kan arte seg forskjellig innenfor ulike samfunnssfærer i et og samme land. Norge gir eksempler på begge deler. Vår spesielt fordelaktige stilling som olje- og gasseksportør, gjorde det mulig å opprettholde velferdspolitiske mål lenger enn tilfellet var i mange andre europeiske land. Likevel, mens den rikspolitiske vendingen mot et liberalistisk regime kom med Margareth Thatcher i Storbritannia i 1979, kom den også til Norge med regjeringen Willoch i 1981. 80-årene kom dermed til å markere en liberalisering på en rekke politikkområder i Norge, også for UH-sektoren. 
Vi kan samtidig si at skillet fra velferdsstatsfasen til den etterfølgende fasen markeres med at geografien igjen ble utfordret. Mange stilte spørsmål ved om UH-sektoren var blitt for fragmentert, og om den besto av for mange og for små enheter til å kunne møte nasjonale og internasjonale krav om kvalitet (Aamodt \& Lyby, 2019). Denne kritikken kom samtidig med at flere utdanningsgrupper tok kampen opp for å rive skillet mellom semiprofesjoner og profesjoner. Den akademiske driften som dette ga opphav til, fikk umiddelbart gjensvar innenfra ved at flere og flere høgskolemiljøer løftet ambisjoner om å bli universiteter.

Før vi forfølger denne utviklingens nyere logikk, må vi stoppe opp litt ved Gudmund Hernes' virke som utdannings- og forskningsminister. I perioden 1990-95 var Gudmund Hernes kirke- og undervisningsminister. Som forsker hadde han utmerket seg som maktutreder og som en betydelig fornyer av norsk sosiologi (Slagstad, 1998, s. 440-444). Skal vi sette en overskrift over hans analyse av staten og dens rolle i samfunnet, kan den oppsummerende antologien fra den første maktutredningen gi kortversjonen: Forhandlingsøkonomi og blandingsadministrasjon (Hernes, 1978). Som statsråd skulle hans normative teori være en annen. Med Hernes får vi en statsråd som utfolder seg med en voldsom virketrang og reformiver. Ambisjonene er store, detaljeringsnivået for hans interesser er nærmest grenseløst. I så måte minner han mer om den første etterkrigstidens økonomiske og industrielle strateger, folk som Erik Brofoss og Jens Chr. Hauge. Som styringsideolog og -praktiker står han nærmere en kontinental dirigisme-tradisjon enn sine egne vitenskapelige analyser av den forhandlende og deliberative stat. Han er ingen liberalist. Han tegner heller systemet fra toppen og stuper om nødvendig ned i detaljene. Han vil strukturendringer, men de skal regisseres ovenfra. Et talende eksempel er hvordan han rundt 1992-93 håndterte de regionale ambisjonene om å fusjonere daværende Agder distriktshøgskole (ADH) og Høgskolesenteret i Rogaland (HSR) til et nytt universitet i sørvest. Statsråden ønsket ingen slik etablering og utfoldet seg med stor sans for detaljer. Han skrev brev til sin danske statsrådskollega, Bertil Haarder, og klassifiserte Ålborg Universitets støtte til HSR som uønsket innblanding i interne norske anliggender (Hernes, 1992). Han ga også beskjed om at administrative reiser mellom de to lærestedene ikke skulle anvises. Til 
slutt avsatte han faglig og administrativ ledelse ved HSR og satte institusjonen under administrasjon (Johnsen, 1999). Det er langt herfra til Solberg-regjeringenes mantra om at fusjoner blir til gjennom konstruktiv naboprat.

På et felt innvarsler han imidlertid den nye tid. Han lanserer nettverkene som middel for å binde en fragmentert sektor sammen. Gjennom Norgesnettet kunne arbeidsdelingen sikres mellom utdannings- og forskningsmiljøer der for mange dublerte hverandre og for få ble eksellente. Men Hernes' nett trengte mer enn en usynlig hånd for å spinnes. Viten fordret vilje, for å parafrasere hans egen tittel på den offentlige utredningen han ledet arbeidet med forut for sin statsrådsgjerning (NOU 1988). Det går en linje her fra Hernes til Steinar Stjernø og hans utvalg 20 år senere (NOU 2008). Igjen er budskapet at sektoren trenger institusjonell konsentrasjon for å møte en ny tids krav. Og igjen er troen på at strukturendringene må skje gjennom handling ovenfra, påfallende sterk. Stjernø-utvalgt skulle møte mye motbør, men når vi i dag kan konstatere at mange av utvalgets visjoner finner sin form, skjer det nærmest malgré soi. En ny orden oppstår, men ut fra en helt annen ideologisk tilnærming. For å se røttene til denne utviklingen må vi igjen gjøre en historisk sving.

Det er ofte gjentatt, også i flere av bidragene i denne antologien, hvordan universiteter og høgskoler i en nasjonsbyggingsfase først og fremst har betydning for utdanning av den akademiske arbeidskraft som behøves for å bygge en nasjon og en nasjonal klasse av forvaltere og embetsmenn. Det bør i denne sammenhengen likevel være interessant å notere seg at tradisjonene med å navngi universiteter oftest refererer til byen de ligger $i$, av og til til regionen, men ikke til landet. Mange av de fremste universitetsbyene er heller ikke hovedsteder, men snarer det vi i dag vil kalle nummer to- eller nummer tre-byer. Noen steder, som i Italia og Tyskland kan vi forklare dette med en broket fortid der småstater, ofte rene bystater, dannet rammen om institusjonsbyggingen. Men vi finner også det samme igjen i stater med en helt annen historie, som i Storbritannia, Sverige og USA. Det er byer, ikke stater, universitetene identifiseres med. Lista over slike byer er som en akademisk adelskalender: Oxford, Cambridge, Heidelberg, Halle, Königsberg, Konstanz, Bologna, Leiden, Leuven, Uppsala, Lund, Dorpat, for å plukke noen av dem. Dette trekket 
har disse kunnskapsinstitusjonene til felles med kulturinstitusjoner som symfoniorkestre og operaer (sjeldnere teatre). De er bybaserte og utvikles i en vekselvirkning mellom makthavere og (dannelses-)borgerskap. Slik forstått utviklet det seg rundt disse institusjonene, med et uttrykk fra Habermas (2002), stedlige, borgerlige offentligheter som på samme tid var regionale og internasjonale. Men bare unntaksvis ble disse byene og kunnskapsinstitusjonene deres forstått som poler for økonomisk vekst og utvikling.

Samtidig var disse regionalt forankrede institusjonene deler av akademiske nettverk som på mange vis var mer internasjonalt preget enn tilfellet er i dag. Det var vanlig at studenter, på samme måte som også lærlinger innenfor håndverksfagene, reiste og tok deler av utdanningen sin utenlands (Pryser, 1982). For Norges del var det å reise utenlands for mange også en nødvendighet med det magre studietilbudet vi hadde her hjemme. Til denne internasjonale orienteringen hørte også språkog kulturkunnskaper. Kunnskaper i latin og gresk, helst også hebraisk, var grunnleggende akademisk ballast. I tillegg skulle en akademiker beherske de viktigste moderne språkene. Minimumsrepertoaret var engelsk, fransk og tysk. En av den moderne samfunnsvitenskapens grunnleggere, Max Weber (1995 [1920]), illustrer i sitt klassiske verk, Den protestantiske etikk og kapitalismens ånd, forventningene både til å kjenne kulturhistoriens regionale mønstre og til å beherske de språklige kodene, samtidig som han peker inn i den nye tid. Denne tiden tror han vil preges av den instrumentelle rasjonalitets økende systemtvang og, for akademias del, til at de førende universitetene på USAs østkyst fortsetter å distansere seg fra sitt puritanske opphav for å legitimere sin posisjon som vitenskapens spydspisser, mens det nord-amerikanske samfunn vil ende opp som verdens mest sekulariserte, og verden gå sin gang: «... indtil det sidste ton fossilt brænstof er gennemglødet» (Weber, 1995, s. 113). Webers kulturanalytiske bomskudd om amerikansk sekularisering og hans profetiske lykketreff om vår tids miljøkrise - egentlig spår han ressurskrise - er forsynt med sitater og referanser på tysk, engelsk, fransk, spansk, italiensk, nederlandsk, dansk, svensk, latin, arabisk, gresk og hebraisk, med de tre siste språkene utranskribert. Ingenting av dette er oversatt. 
Vi kan altså tale om en nettverksbyggende og global, om enn eurosentrert, akademisk kultur forut for den nettverkende vending vi er vitne til i vår egen tid. Legger vi til at den europeiske universitetskulturen står helt sentralt for fremveksten av det europeiske opplysningsprosjektet og dets metaliberale ramme i stort, og for liberalismen som eksplisitt ideologi i mer avgrenset mening (Hirschmann, 1977; Johnsen, 2014), må vi kunne konkludere med at Bevirs neoliberale og nettverkende stat er en samtidig variasjon over kjente tema. Skal vi se på hva som kjennetegner denne samtidige nytolkning med særlig henblikk på forskning og høyere utdanning, kan følgende tre aspekter være viktige:

- Koplingen mellom akademia og økonomisk utvikling gjøres eksplisitt og blir også programmatisk.

- Koplingen mellom regionalitet og globalisering gjøres analytisk eksplisitt.

- Den akademiske internasjonaliseringsdimensjonen går fra å være multippel til å bli monokulturell og anglofon.

Punkt 1: Forholdet mellom den typen kunnskap som skapes gjennom akademia og den utvikling som dette gir opphav til, blir gjenoppdaget og plassert som en del av den typen naturressurs som nettopp universiteter og høgskoler og institusjoner i deres randsoner skal raffinere til samfunnets beste (Johnsen, 2014). Denne kunnskapsraffineringen blir igjen koplet til bestemte innovasjonsmåter som så vil kunne være hegemoniske eller fraværende innenfor ulike regioner, gitt deres næringsmiks og industrielle historie (Asheim \& Gertler, 2005; Jensen et al., 2007). Denne måten å tenke på danner så fundament for nasjonal og europeisk økonomisk og næringspolitisk utforming, der regionenes evne til å utmeisle kompetitive fortrinn blir forstått som nøkkelen til fremtidig regional, nasjonal og europeisk økonomisk vekst (Fitjar et al., 2016; Foray, 2015; Reve \& Sasson, 2012). Koplingen mellom akademia og den regionale innovasjonsevnen blir gjort eksplisitt og formet til et politisk credo som griper over ideologiske skillelinjer (Reichert, 2019).

Punkt 2: Den fornyede interessen for regionens innpass i den internasjonale orden kan spores langs to ulike dimensjoner. Den første utgjøres 
av den fornyede interessen for regionen som analyseenhet innenfor økonomisk geografi. I en verden som utover i etterkrigstiden blir stadig mer avhengig av global handel og regional spesialisering, skifter mye av det analytiske fokus for å forstå denne utviklingen fra å se på stater som økonomiske entiteter til å se på regionale produksjonssystemer som dynamoer for vekst (Cooke, 2001; Porter, 1990). På det politiske plan førte utviklingen innenfor EU, særlig fra midten av 1980-tallet av, til en fornyet oppmerksomhet om regionen som politisk enhet og aktør til utvikling av begrepet regionenes Europa (Borrás-Alomar mfl., 1994). Selv om den realpolitiske bedømmingen av denne utviklingen var ulik (Magone, 2003), førte den med seg opprettelse av en rekke virkemidler for regional utvikling, hvorav flere enten eksplisitt var rettet mot UH-sektoren eller fordret at myndigheter, foretak og tredje sektor-organisasjoner kjøpte regionalt relevant akademisk bistand. Lanseringen av RIS3 eller Smart Spesialisering (Foray, 2015) som en obligatorisk analyseøvelse for regioner som ville søke europeiske strukturfondmidler, kan ses på som en gjenopptakelse av dette sporet.

Punkt 3: Utviklingen av den internasjonale dimensjonen innenfor forskningsverden, kan ses på som paradoksal. Spissformulert kan vi si at mens interessen for regionalt mangfold øker innenfor samfunnsvitenskapene, kles denne interessen språklig og arenamessige opp ganske så endimensjonalt. Der Webers mangespråklige og kulturelt heterogene referanser rådet, er situasjonen i dag entydig anglofon. Og hva verre er: Den internasjonale bedømmingen av faglige forskningsbidrag og rangering av institusjoner følger en lignende tendens. Jevnlig fores vi med oversikter i mediene som skal overtale oss til å tro at verdens beste universiteter uomtvistelig er engelskspråklige. Der vi tidligere kunne si publish or perish, kan vi nå si publish in English or perish. Den anglofone vending kan slik bedømmes som en strigling og en fattiggjøring av den akademiske diskursen. Debatten om denne utviklingens følger har vi også i Norge, blant annet knyttet til om norsk vil overleve som akademisk språk. Tenker vi på språket i Gert Hofstedes (1999) termer som kulturens programvare, er det all grunn til å rope et varsku. Vi er i ferd med å bli monokulturelle.

Innenfor denne måten å se sektoren på svinner geografiens betydning. Når Torbjørn Røe Isaksen som statsråd i 2015 skal beskrive sin oppskrift 
for endring i den norske UH-strukturen, gjør han det, slik Frølich mfl. (2019) refererer, ved å angi noen overordnede kvalitative krav. Utfra disse vil nødvendige strukturendringer måtte skje, men ikke som hos Hernes, diktert ovenfra. Isaksen stoler på prosessen og den disiplinerende virkning den måtte ha. Her er det en parallell mellom reformforløpet innenfor UH-sektoren og de prosessene som har styrt de samtidige kommune- og regionreformene i Norge. Naboprat og frivillighet angis som middel. Så kan staten i beste fall skru litt på insentivene og dermed antyde at den har en pistol i lommen. Geografien blir som den blir, den kartfester resultatet, men er ikke interessant ut over det. Den er blitt som teologien i senere norsk politikk, noe underordnet. Ennå skal det visstnok feste skam knyttet til å være historieløs. I den neoliberale stat er det derimot stuerent å være geografiløs, også i Norge.

\section{Avslutning}

Denne artikkelen har festet fremveksten av høyere utdanning og forskning til tre ulike stadier i nasjonens utvikling. Til disse tre stadiene er det knyttet ulik forståelse av den rollen og den betydning høyere utdanning og forskning har for landet og for den geografi landet er konstituert ved. Jeg har argumentert for at geografi alltid har vært viktig for nasjonsbyggingen i Norge. Dette gjelder også for etablering at landets kunnskapsinstitusjoner.

I et bredere europeisk perspektiv kan vi gjerne si at region- og nasjonsbygging er to sider av samme sak. Mange nasjoner har aldri realisert seg selv som nasjonalstater (Sameland, Baskerland), mens andre stater er utpreget multinasjonale (Belgia, Sveits) eller deler nasjonalitet med andre (Tyskland, Østerrike). Universitetene spiller her en tvetydig historisk rolle. Selv om de kom til for å utdanne lærde til kirkelig og verdslig maktutøvelse, bar mange av de fremste blant dem navn etter den byen de preget og var en del av. Kunnskaps- og kulturinstitusjoner har i Europa alltid hatt en regional affinitet. Samtidig har de alltid vært del av kosmopolitiske nettverk og fellesskap.

Med nasjonalstatens ekspansjon gjennom velferdsstatsprosjektet etter annen verdenskrig vokser universitets- og høgskolesektoren voldsomt, 
både i volum og geografi. I Norge når antall høyere læresteder sitt maksimum forut for reformbølgen på 1990-tallet. Deretter følger en rekke fremstøt for konsentrasjon og arbeidsdeling. Under Gudmund Hernes' tid som statsråd følger denne bestrebelsen en klassisk toppstyrt modell. Senere forsøk på å konsentrere antall institusjoner er i langt sterkere grad inspirert av å mobilisere og stimulere aktørene til selv å søke samarbeid og fusjon.

Parallelt med fremveksten av den neoliberale og nettverkende stat, oppstår det internasjonalt en ny forståelse av regionens betydning, både som politisk arena og økonomisk motor. Denne nye innsikten gir seg umiddelbare politiske utslag både i EU og i Norge, men i utdanningspolitisk sammenheng er responsen tvetydig. Man setter sin lit til regionale aktørers evne til å gruppere og omgruppere seg for en mer effektiv og slagkraftig utdanningssektor. Men samtidig som kunnskapen gjenoppdages som tidens fremste ressurs (Johnsen, 2014), har norske rikspolitikere ingen mening om det er viktig å tenke strategisk geografisk om denne kunnskapens lokalisering og regionale tilstedeværelse. Det kan koste dem dyrt. Skal vi tolke de politiske konjunkturene slik de fremstår i skrivende øyeblikk, er en ny geografibevissthet i emning. Den bruker bunaden som merke og kan raskt bevege seg fra seg en sektor til en annen. Kanskje er geografiløshetens tid omme.

\section{Referanser}

Arbo, P. (2019). Universitet og region - en sammensatt relasjon. I J. P. Knudsen \& T. Lauvdal (Red.), Geografi, kunnskap, vitenskap. Den regionale UH-sektorens framvekst og betydning (s. 99-130). Oslo: Cappelen Damm Akademisk. https:// doi.org/10.23865/noasp.73.ch4

Asheim, B. T. \& Gertler, M. S. (2005). The geography of innovation. Regional innovation systems. I J. Fagerberg, D. C. Mowery, \& R. R. Nelson (Red.), The Oxford handbook of innovation (s. 291-317). Oxford: Oxford University Press. Banke, N. (1955). Om Adam Smiths forbindelse med Norge og Danmark. Nationaløkonomisk Tidsskrift, 93, 170-178.

Bevir, M. (2011). Democratic governance: A genealogy. Local Government Studies, $37(1), 3-17$.

Blom, G. A. (1957). Fra bergseminar til teknisk høyskole. Utgitt ved 20o-års jubiléet for den høyere tekniske undervisning i Norge. Oslo: Teknisk ukeblad. 
Brox, O. (1966). Hva skjer i Nord-Norge? En studie i norsk utkantpolitikk. Oslo: Pax. Brox, O. (1984). Nord-Norge: Fra allmenning til koloni. Oslo: Universitetsforlaget. Borrás-Alomar, S., Christiansen, T. \& Rodríguez-Pose, A. (1994). Towards a 'Europe of regions'? Visions and reality from a critical perspective. Regional Politics and Policy, 4(2), 1-27.

Bukve, O. (2005). Norske regionalistar - kan dei samlast bak ei reform? I J. P. Knudsen (Red.), Sterke regioner - forsking og reform (s. 197-220). Bergen: Fagbokforlaget.

Cooke, P. (2001). Regional innovation systems, clusters, and the knowledge economy. Industrial and Corporate Change, 10(4), 945-974.

Dale, E. L. (1999). De strategiske pedagoger. Oslo: Ad Notam Gyldendal.

Ekspertutvalget for regionreformen. (2018). Regionreformen. Desentralisering av oppgaver fra staten til fylkeskommunene. Oslo: Kommunal- og moderniseringsdepartementet. Hentet fra www.regjeringen.no/kmd ESPON (2014). ESPON ATLAS. Mapping European Territorial Structures and Dynamics. Luxembourg: ESPON\&BBSR.

Fagerberg, J., Mowery, D. C. \& Verspagen, B. (2009). The evolution of Norway's national innovation system. Science and Public Policy, 36(6), 431-444.

Fet, J. (1995). Lesande bønder: Litterær kultur i norske allmugesamfunn før 1840. Oslo: Universitetsforlaget.

Fitjar, R. D. \& Alpaydin, U. A. R. (2019). Næringslivets samhandling med universiteter i og utenfor regionen: Funn fra en undersøkelse av norske bedrifter. I J. P. Knudsen \& T. Lauvdal (Red.), Geografi, kunnskap, vitenskap. Den regionale UH-sektorens framvekst og betydning (s. 177-194). Oslo: Cappelen Damm Akademisk. https://doi.org/10.23865/noasp.73.ch7

Fitjar, R. D., Isaksen, A. \& Knudsen, J. P. (2016). Politikk for innovative regioner. Oslo: Cappelen Damm Akademisk.

Fitjar, R. D. \& Rodriguez-Pose, A. (2013). Firm collaboration and modes of innovation in Norway. Research Policy, 42(1), 128-138.

Foray, D. (2015). Smart specialisation: Opportunities and challenges for regional innovation policy. London: Routledge.

Frølich, N., Trondal, J., Caspersen, J. \& Reymert, I. (2019). Reformer i UH-sektoren. Det muliges kunst. I J. P. Knudsen \& T. Lauvdal (Red.), Geografi, kunnskap, vitenskap. Den regionale UH-sektorens framvekst og betydning (s. 75-95). Oslo: Cappelen Damm Akademisk. https://doi.org/10.23865/noasp.73.ch3

Gilje, N. \& Rasmussen, T. (2002). Tankeliv i den lutherske stat 1537-1814. Norsk idéhistorie bd II. Oslo: Aschehoug.

Habermas, J. (2002). Borgerlig offentlighet. Oslo: Gyldendal.

Hanisch, T. J., Søilen, E. \& Ecklund, G. (1999). Norsk økonomisk politikk i det 20. århundre. Verdivalg $i$ en åpen økonomi. Kristiansand: Høyskoleforlaget. 
Hansen, J. C. (1972). Regional disparities in Norway with reference to marginality. Transactions of the Institute of British Geographers, 57, 15-30.

Harvey, D. (1989). The condition of postmodernism. An inquiry into the origins of cultural change. Oxford: Blackwell.

Hatland, A., Kuhnle, S. \& Romøren, T. I. (Red.) (2018). Den norske velferdsstaten. Oslo: Gyldendal.

Helsvig, K. G. (2005). Pedagogikkens grenser. Oslo: Abstrakt forlag.

Hernes, G. (1992). Brev til Bertil Haarder. 14.01.1992. KUF: ref. 92/46o Uh H.

Hernes, G. (Red.) (1978). Forhandlingsøkonomi og blandingsadministrasjon. Oslo: Universitetsforlaget.

Hirschman, A. O. (1977). The passions and the interests. Political arguments for capitalism before its Triumph. Princeton, NJ: Princeton University Press.

Hofstede, G. (1991). Cultures and organizations. Software of the mind. London: MacGraw-Hill.

Illeris, S. (1990). Counter-urbanization revisited: The new map of population distribution in central and north-western Europe. Norsk Geografisk Tidsskrift Norwegian Journal of Geography, 44(1), 39-52.

Industridepartementet. (1982). Om teknisk-industriell forskning og utvikling. (St. meld. 54 (1982-83)). Oslo: Industridepartementet.

Jensen, M. B., Johnson, B., Lorenz, E. \& Lundvall, B.-Å. (2007). Forms of knowledge and modes of innovation. Research Policy, 36(5), 680-693.

Johnsen, B. W. (1999). Fra universitetsvisjon til høyskoleintegrasjon. Studia Humanitatis Bergensia. Kristiansand: Høyskoleforlaget.

Johnsen, H. C. G. (2014). The new natural resource. Knowledge development, society and economics. London: Routledge.

Johnstad, T., Klausen, J. E. \& Mønnesland, J. (2003). Globalisering, regionalisering, distriktspolitikk. Rapport 76. Oslo: Makt- og demokratiutredningen.

Knudsen, J. P. (2015). Skolen som regionalt prosjekt. I G. Langfeldt (Red.), Skolens kvalitet skapes lokalt. Presentasjon av funn fra forskningsprosjektet «loerende regioner» (s. 31-65). Bergen: Fagbokforlaget.

Knudsen, J. P. (2018). Towards a new spatial perspective - Norwegian politics at the crossroads. Norsk Geografisk Tidsskrift - Norwegian Journal of Geography, 72(2), 67-81.

Krokann, I. (1982) [1942]. Det store hamskiftet. Oslo: Samlaget.

Kunnskapsdepartementet. (2014). Konsentrasjon for kvalitet - strukturreform i universitets- og høyskolesektoren. (Meld. St. 18 (2014-2015)). Oslo:

Kunnskapsdepartementet.

Kurrild-Klitgaard, P. (1998). Adam Smith og kredsen bag National-Velstands Natur. Ideer om Frihet, 3/1998. 
Magone, J. M. (Red.) (2003). A Europe of the regions: Rhetoric or reality? Westport, CT: Praeger.

NOU 1981: 30. (1981) Forskning, teknisk utvikling og industrielle innovasjon. En vurdering av den offentlige støtte til teknisk-industriell forskning og utvikling i Norge. Oslo: Industridepartementet.

NOU 2008: 3. (2008). Sett under ett. Ny struktur i høyere utdanning. Oslo: Kunnskapsdepartementet.

NOU 1988: 28. (1988). Med viten og vilje. Oslo: Kulturdepartementet.

OECD (2018). Education at a Glance 2018. Education Indicators. Hentet fra www. oecd.org/education/education-at-a-glance.

Oftestad, B. T. (1998). Den norske statsreligionen. Fra øvrighetskirke til demokratisk statskirke. Kristiansand: Høyskoleforlaget.

Porter, M. E. (1990). The competitive advantage of nations. New York: The Free Press.

Porter, M. E. (2000). Attitudes, values, beliefs, and the microeconomics of prosperity. I L. E. Harrison \& S. P. Huntington (Red.), Culture matters: How values shape human progress. New York: Basic Books.

Pryser, T. (1982). Geseller, rebellar og svermarar. Om «farlege folk» kring 1850. Oslo: Samlaget.

Reichert, S. (2019). The role of universities in regional innovation ecosystems. EUA Studies. Brussel/Genève: European University Association.

Reve, T. \& Sasson, A. (2012). Et kunnskapsbasert Norge. Oslo: Universitetsforlaget.

Rokkan, S. (1967). Geography, religion and social class: Crosscutting cleavages in Norwegian politics. I S. M. Lipset \& S. Rokkan (Red.), Party systems and voter alignments: Cross-national perspective (s. 367-444). New York: The Free Press.

Røed, H. (2018). Ola tiltak. En biografi om den politiske strategen Ole Colbjørnsen, Oslo: Gyldendal.

Slagstad, R. (1998). De nasjonale strateger. Oslo: Pax.

Sæther, A. (2018). Oslo-skolen og den politiske debatt i Norge. Foredrag på Det 15de nordiske møde om økonomisk idéhistorie, Roskilde: 23.-24. august 2018.

Sæther, A. \& Eriksen, I. E. (2014). Ragnar Frisch and the postwar Norwegian economy. Econ Journal Watch, 11(1), 46-80.

Teigen, H. (2012). Distriktspolitikk gjennom 50 år - Strategane og avviklinga. Nytt Norsk Tidsskrift, 11(2), 157-165.

Weber, M. (1995) [1920]. Den protestantiske etikk og kapitalismens ånd. Oslo: Gyldendal.

Wicken, O. (1997). Regionenes industrialisering - et historisk perspektiv. I A. Isaksen (Red.), Innovasjoner, næeringsutvikling og regionalpolitikk (s. 50-65). Kristiansand: Høyskoleforlaget. 
Wicken, O. (2004). Politikk som konkurranse mellom industrialiseringsformer. I P. Arbo \& H. Gammelsæter (Red.), Innovasjonspolitikkens scenografi: Nye perspektiver på noeringsutvikling (s. 50-66). Trondheim: Tapir.

Aamodt. P. O \& Lyby, L. (2019). Instrument eller institusjon? Skiftende politiske prioriteringer. I J. P. Knudsen \& T. Lauvdal (Red.), Geografi, kunnskap, vitenskap. Den regionale UH-sektorens framvekst og betydning (s. 25-52). Oslo: Cappelen Damm Akademisk. https://doi.org/10.23865/noasp.73.ch1

Aarsæther, N., Nilsen, R. \& Reiersen, J. E. (1982). Folkemakt og regional utvikling: Til Ottar Brox' 50-årsdag. Oslo: Pax. 


\section{Om bidragsyterne}

Utku Ali Rıza Alpaydın er stipendiat ved Avdeling for innovasjon, ledelse og markedsføring ved Handelshøgskolen ved Universitetet i Stavanger og tilknyttet Senter for innovasjonsforskning. Han deltar i Marie Skłodowska Curie-nettverket «The Role of Universities in Innovation and Regional Development (RUNIN)», finansiert av EUs Horisont 2020-program.

Peter Arbo er professor ved Norges fiskerihøgskole, Universitetet i Troms $\varnothing$ - Norges arktiske universitet. Han har gjennom mange år forsket på samspillet mellom universitet og region, særlig med utgangspunkt $\mathrm{i}$ nordnorske erfaringer. Han var med i OECD-prosjektet «Supporting the Contribution of Higher Education to Regional Development», og har også vært medlem av ulike styrer, råd og utvalg, slik som styret ved Norges fiskerihøgskole, universitetsstyret i Tromsø, styret for Høgskolen i Lillehammer/Høgskolen i Innlandet samt SIVA og Stjernøutvalget.

Ivar Bleiklie er professor emeritus ved Institutt for administrasjon og organisasjonsvitenskap ved Universitetet i Bergen. Han har publisert en rekke bøker og artikler om reformpolitikk og organisatoriske endringer innen høyere utdanning i et europeisk sammenlignende perspektiv

Joakim Caspersen er sosiolog og forsker 1 ved NTNU Samfunnsforskning i Trondheim.

Rune Dahl Fitjar er prorektor for innovasjon og samfunn ved Universitetet i Stavanger. Han er professor i innovasjonsstudier på Handelshøgskolen ved UiS og tilknyttet Senter for innovasjonsforskning. Han leder Marie Skłodowska Curie-nettverket «The Role of Universities in Innovation and Regional Development (RUNIN)», finansiert av EUs Horisont 2020-program. 
Nicoline Frølich er Forskningsleder for Studier av Høyere utdanning ved NIFU og Forsker 1 ved samme sted. Hun har doktorgrad i sammenliknende politikk fra Universitetet i Bergen og er siviløkonom fra Norges Handelshøyskole. Hennes forskningstema er styring, ledelse og organisering i høyere utdanning. Hun skal lede den forskningsbaserte evalueringen av Strukturreformen.

Linda Helén Haukland er førstelektor i samfunnsfag ved Nord universitet. Hun er forfatter av bøkene Hverdag i ruinene. Bodø 1940-1945 fra 2012, Nye høyder. Framveksten av Universitetet i Nordland fra 2015 og Lærerutdanninga på Nesna 1918-2018 fra 2018, i tillegg til flere fagartikler om Hans Nielsen Hauge og haugianismen. Haukland har master i historie fra 2010 med tema "Narrativ og faktuell tilnærming til muntlige kilder" og PhD i sosiologi fra 2018 med tittelen "Universitetet i Nordland: spenninger og samspill i en høgskolesektor”.

Hans Christian Garmann Johnsen er professor ved Institutt for arbeidsliv og innovasjon på Handelshøyskolen ved Universitetet i Agder. Han har er siviløkonom fra Norges handelshøyskole og har en doktorgrad (PhD) fra Copenhagen Business School.

James Karlsen er professor ved Institutt for arbeidsliv og innovasjon på Handelshøyskolen ved Universitetet i Agder. Han har doktorgrad fra Industriell økonomi ved NTNU. Karlsens forskningsinteresse er regional innovasjon og regional utvikling, samspill mellom høyere utdanningsinstitusjoner og regionale aktører.

Jon P. Knudsen er førsteamanuensis ved Universitetet i Agder. Han er Fil. dr. i kulturgeografi fra Lunds Universitet (1994). Han har tidligere vært politisk redaktør i Fædrelandsvennen og dekan ved Fakultet for økonomi og samfunnsvitenskap ved UiA. Han satt også i Ekspertutvalget for Regionreformen. Han har særlig arbeidet med kultur, politikk og plan i et regionalt perspektiv.

Torunn Lauvdal er professor emerita ved Universitetet i Agder. Hun er dr.polit fra Universitetet i Trondheim. Lauvdal var rektor ved UiA 
2007-2016. Hun ledet regjeringens Sørlandsutvalg og har sittet i en rekke styrer og råd innen UH og forskningssektoren.

Lars Lyby har en ph.d. i sosiologi og arbeider som forsker ved NIFU, hvor han primært forsker på høyere utdanning.

Roger Normann er seniorforsker i NORCE Norwegian Research Centre. Han har en doktorgrad fra Norges teknisk-naturvitenskapelige universitet (2007).

Rómulo Pinheiro er professor i Offentlig Forvaltning og Organisasjon ved Universitetet i Agder. Han er også gjesteprofessor ved Universitetet I Tampere, Finland.

Ingvild Reymert, stipendiat og forsker, NIFU. Reymert har studert organisering av høyere utdanningsinstitusjoner, studenters arbeidsmarkedstilpassing og akademiske karrierer. I hennes doktorgrad ser hun på evaluering av forskningskvalitet i akademiske ansettelsesprosesser.

Jarle Trondal er professor ved Institutt for statsvitenskap og ledelsesfag ved Universitetet i Agder, og professor ved ARENA, Senter for Europaforskning ved Universitetet i Oslo.

Per Olaf Aamodt er utdannet som sosiolog fra Universitetet i Oslo i 1972. Han har arbeidet i Statistisk sentralbyrå i mer enn ti år, og deretter ved NIFU (de siste årene som freelance). Han har drevet forskning om sosiale ulikheter i utdanningssystemet, rekruttering og gjennomføring av høyere utdanning, og om kvalitet i høyere utdanning. Dessuten har han vært involvert i større evalueringer av utdanningsreformer, blant annet Reform 94 og Kvalitetsreformen. Han var medlem av Mjøs-utvalget 1998-20oo. 
